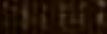

afi:

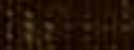

st:

F

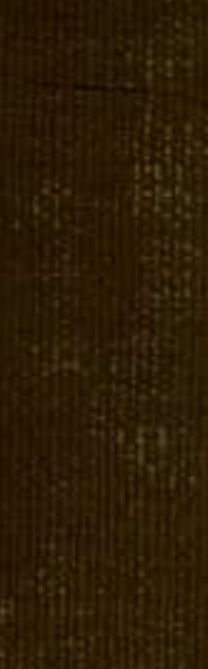

9.9.

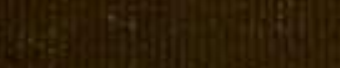



15

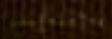




\section{GIIT OF}

\section{HORACE W. CARPENTIER}

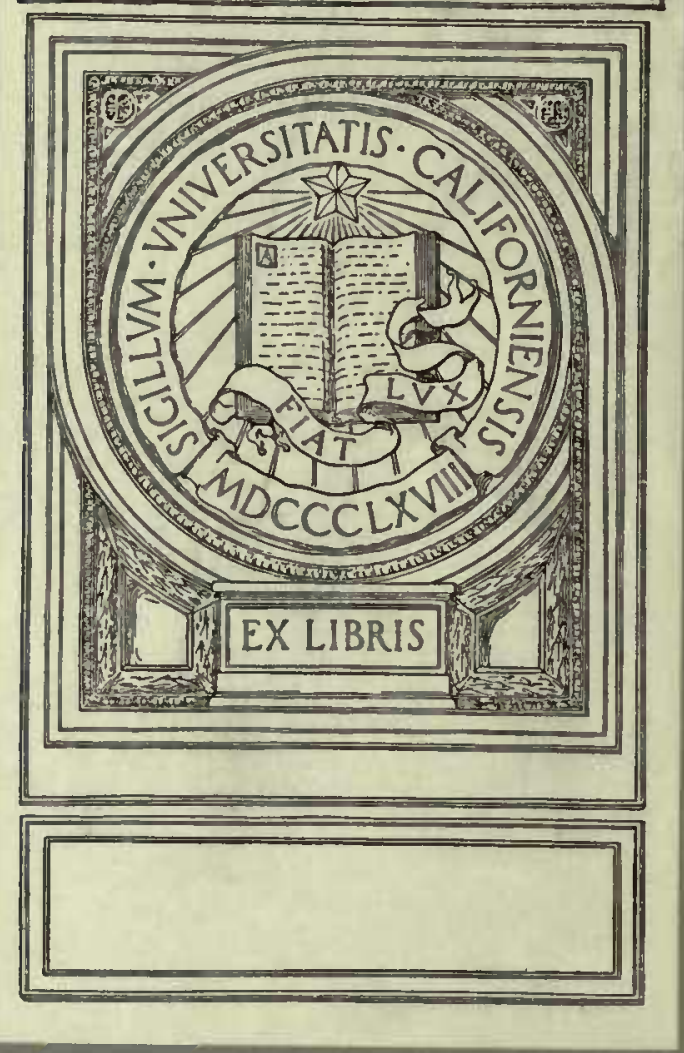




$\because$

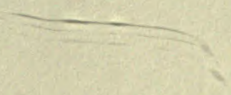





\section{DOGS OF CHINA $\wp^{\circ}$ JAPAN IN NATURE AND ART}




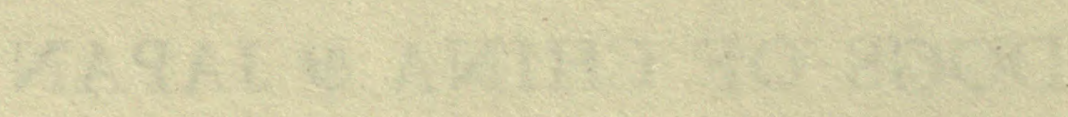




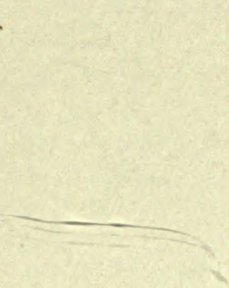

$$
\begin{aligned}
& \text { a } \\
& \therefore \therefore \therefore \because \because \because \cdots
\end{aligned}
$$




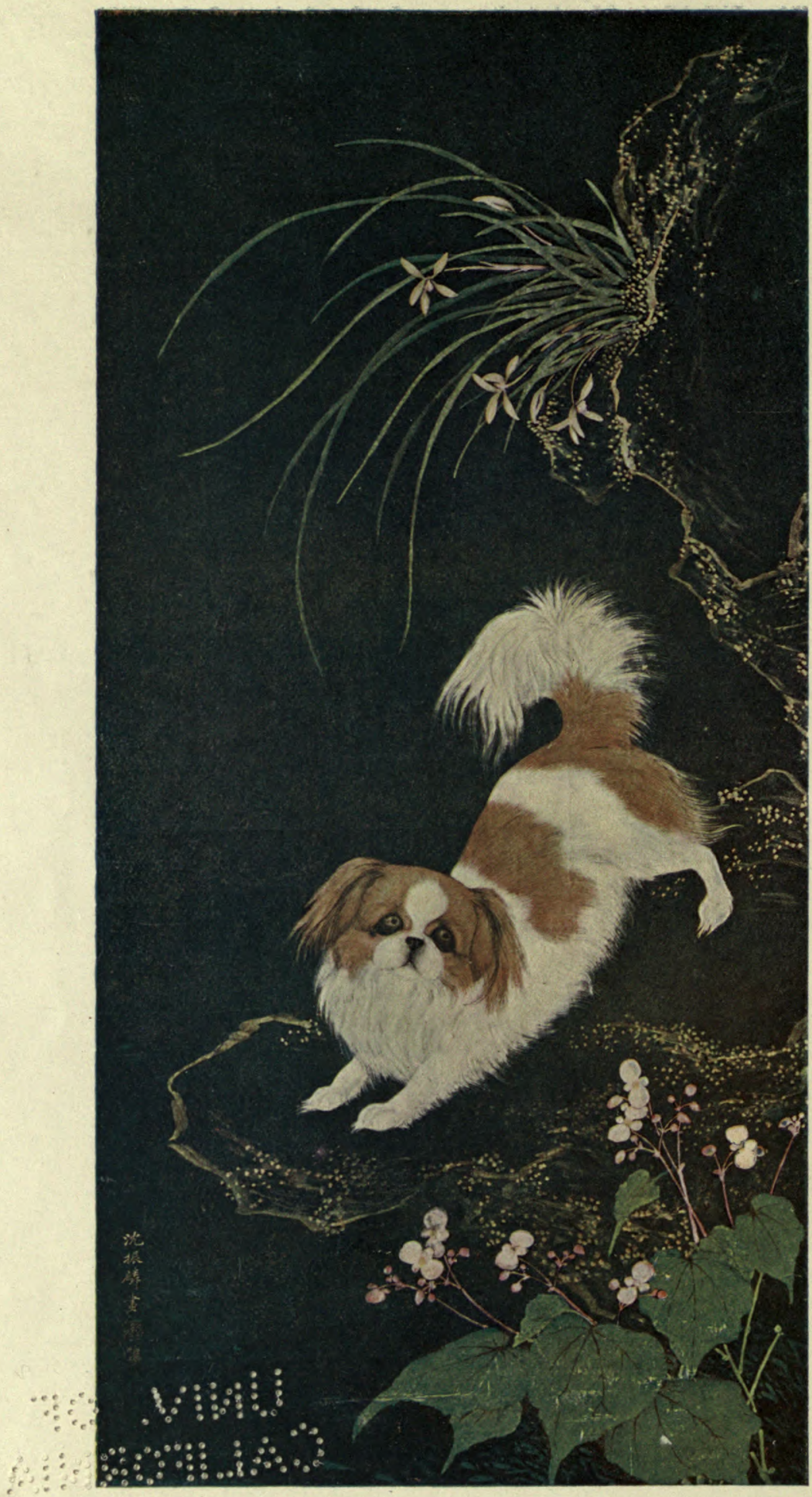




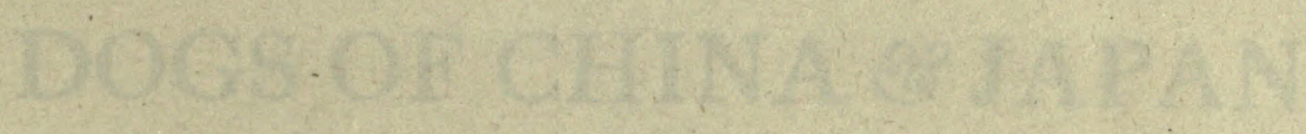

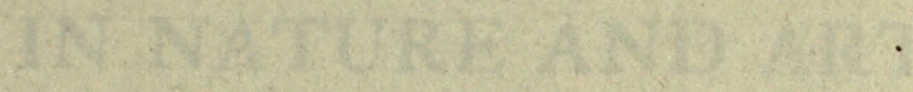

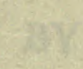

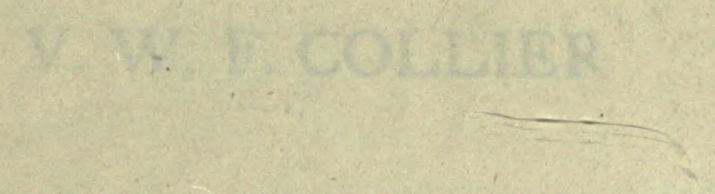

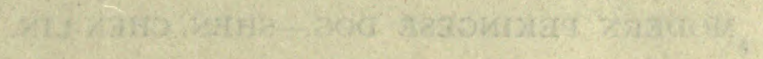

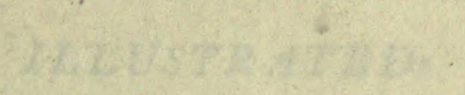

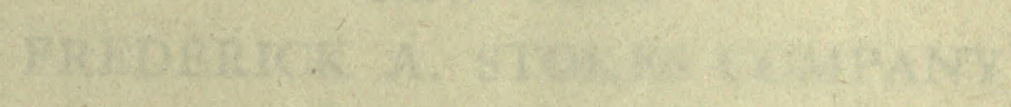

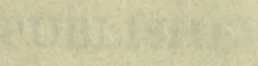


MODERN PEKINGESE DOG.-SHEN CHEN-LIN. 


\title{
DOGS OF CHINA שூ JAPAN IN NATURE AND ART.
}

\author{
BY \\ V. W. F. COLLIER
}

ILLUSTRATED

1921

NEW YORK

FREDERICK A. STOKES COMPANY

PUBLISHERS 
$$
\text { SF } 427
$$

C 6

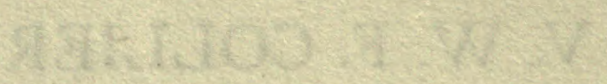

carpenter

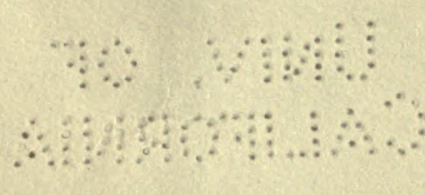

Printed in Great Britain. 


\section{PREFACE}

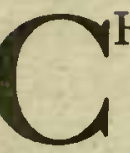

HINA and Japan, their people and their customs, have lured the foreigner in his thousands to the making of many books. No writer, however, has thought fit to devote much study to their canine race, though in the Far East, just as in Europe, the dog has been for ages man's chief help and protector :

The rich man's guardian and the poor man's friend,

The only creature faithful to the end."

Those who have, in passing, deigned to notice the existence of dogs in the Far East have paused only for brief comment, usually by way of grasping another stick to beat the Celestial for gastronomic eccentricity or superstitious delusions, and have given to the Eastern canine races scarcely the proverbial "dog's chance" of being considered better than universally mongrel.

It is not claimed for the following pages, whose original design included only the smaller races of Eastern dogs, that they enumerate all the existing breeds, or that they deal conclusively with any one of them. China alone is a vast country in which geographical difficulties render comprehensive study difficult. It is hoped, nevertheless, that there has been laid a foundation upon which further investigation may be firmly based, and that the researches made may assist in the identification of new species as well as the preservation of certain breeds which, like the St. Bernard in Europe, now run the risk of following the Irish wolfhound and the hard-worked turnspit dog of our great-grandfathers, to extinction.

\footnotetext{
* Inscription on the monument to a Newfoundland dog. Byron.
} 


\section{PREFACE}

The assistance received from Chinese and Japanese literature has been but slight, for though from the earliest days Eastern Emperors and their subjects have recognized the qualities of the dog-

in life the firmest friend,

The first to welcome, foremost to defend,

Whose honest heart is still his master's own,

Who labours, fights, lives, breathes for him alone,*

no Eastern writer has thought fit to devote a volume to study of the species. Almost every Chinese and every Japanese is fond of pets individually, bird, insect, or canine; but for dogs generally the same individual is apt to manifest contempt.

Absence of European specialization and training of the breeds has deprived the Chinese and Japanese of enjoyment of those particular canine qualities which have for centuries given much of the zest of life to the sportsman in Europe and, moreover, provide no small interest to the soldier, fowler, trainer, shepherd, and breeder.

From certain State papers it has been possible to show that from very early periods the dog has been used extensively by European and Eastern monarchs as State presents. The emperors and kings of the past prided themselves on their success in adapting dogs to the varied uses of the chase, and this success, which fell in no small measure to British trainers, was utilized on many occasions for the promoting of friendly intercourse with foreign countries.

The culture of Japan, including much of its religion and art, has its origin in China. The scantiness of literature dealing with Japanese dogs is, consequently, compensated to some extent by the comparative wealth of Chinese sources of information. The two chapters dealing with the Buddhist lion and its symbolism represent a considerable amount

* Inscription on the monument to a Newfoundland dog. Byron. 


\section{PREFACE}

of research in both Eastern and European writings. It is hoped that the information gained will prove of value to searchers working far beyond the limited scope comprised within the title of this work.

The author acknowledges a deep sense of obligation to certain Chinese friends for their enthusiastic help in a task which, from an interesting hobby, has developed into the product of much study. Little of the Chinese literary material obtained would have come to light but for the enthusiasm of Mr. Wu Ch'i-ts'un, who, having become interested in the subject, attacked it with painstaking and scholarly ardour. He has carefully examined all records accessible in Peking. His researches were at first confined to the breed of dogs commonly known in Europe as "Pekingese," but information bearing on other breeds has been obtained, and is recorded for those who may be interested. In the second place a debt must be gratefully acknowledged to Wang Houchun, who, though but a humble admirer of the Imperial breed, has, through his seventy-five years' experience as keeper of dogs and hawks, spent for the most part in the palace of Prince Wu Yeh, brother of the Emperor Tao Kuang, proved a mine of information on matters canine. Special thanks are also due to Abbot Pai Kuong-fa of the Lama Temple in Peking, who has been kind enough to point out the exact connexions between Tibetan and Chinese lion dogs, the Chinese lion, and the Tibetan Scriptures. From these last certain references which are of considerable interest have been collected. Additional thanks are due to General Ch'ien Hsi-lin, previous Chief of Intelligence in charge of the Police dogs of President Yuan Shih-k'ai, and Mr. Kungpah T. King, formerly of the Board of Interior, also to numerous others, both Chinese and foreign, in Peking, who have supplied information and corroboration on many points. 
The author gratefully acknowledges his indebtedness to Berthold Laufer, for the use of his authoritative and invaluable work on "Chinese Pottery of the Han Dynasty," published by the East Asiatic Committee of the American Museum of Natural History. This work has been much used and quoted. "Toy Dogs and their Ancestors," by the Hon. Mrs. Neville Lytton, has also been freely consulted. Acknowledgments are also due to the numerous authors of the works cited in the notes.

It is possible that the records of the Chinese Imperial Palace will, if they become available, throw further light upon the origin and history of the Pekingese type of dog. They may also explain how much of its quality the British spaniel breed owes to Chinese ancestors. That the English pug is descended from the Chinese dog may be considered as settled. It appears not unlikely that the King Charles spaniel is descended from a short-headed Chinese race. More light is required on the history of the Tibetan and Japanese races, but the outline of their development is now clear.

It is hoped that the information gained may prove, by indicating something of the age of the Pekingese race and the reasons for its special characteristics, to be of some assistance to the experiments which have, for some years, been carried out at University College, London, with Pekingese dogs, in connexion with Mendelism. There appears to be no doubt that a distinct breed of white non-albino Pekingese, though now extinct, has existed in the Imperial Palace.

The Chinese, Tibetan, Japanese, or Mongol scholar may find small points for debate in some of the translations. It has not been possible to secure the checking of them all by high authorities, but the sense certainly represents a close approximation to the original meaning. Special care has been taken to secure good authority for all quotations and viii 


\section{PREFACE}

statements. The Tibetan translations have presented special difficulties. The language of Tibetan gospels written in ancient Lama script is not simple of comprehension, even to the Lama. The lack of scholars possessing a knowledge of Tibetan has necessitated transliteration by Lamas who, having no knowledge of Chinese characters, wrote in Mongol script. The Mongolian character had then to be translated into Chinese before ultimate reduction to English.

It is hoped that even to those who take no interest in dogs, the following pages may be attractive because of the sidelights thrown on Chinese history, together with Eastern palace life, and the inter-State relations of the long line of Emperors who have dominated the world's oldest ruling race. Modern research tends to prove that more of the East than was generally imagined is akin to the West. On the other hand, not a little of Western canine life owes its origin and distinctive peculiarities to the East. 



\section{CONTENTS}

\section{CHAPTER I.}

\section{EASTERN DOGS IN EARLY TIMES.}

Geological history of the dog in Europe. Its domestication. Ancient records of tribute dogs. Dog-worship by ancient Egyptians and Aryans. Attitude of Confucius toward dogs. Use of dogs by Chinese and Japanese Emperors for sporting purposes, also as pets.

Pp. 1-I 9

\section{CHAPTER II.}

\section{DOG-LORE AND SUPERSTITION.}

Use of dogs for culinary purposes in China, Corea, Indonesia, America and Europe. Dog-sacrifices. Former reverence for dogs in Japan. The God Erh Lang protector of dogs. His temple in Peking. The Heavenly Barking Dog which eats the sun and moon in eclipses. Dogs in Buddhism, Lamaism, Taoism and Fengshui.

Pp. 20-43

\section{CHAPTER III. \\ DOG-BREEDING.}

Its political importance in China and in Europe in mediaval times. The dogs of Kublai Khan. Cats of the Ming period. Lap-dogs and pigeons of Tao Kuang period. Imperial dog-books. Dogs of the late Empress Dowager. Commercial breeding of dogs in Manchuria and Mongolia.

Pp. 44-55

\section{CHAPTER IV.}

\section{SPORTING AND GUARD DOGS.}

Ancient Chinese sporting dogs. The mastiff in ancient China and mediaval Europe. Falconry. Its origin and practice in Europe, China and Japan. Development of scent in dogs. Use of the fowling-piece. The chow dog. Chinese sledge-dogs. The greyhound in China and in Europe. The small greyhound of Shensi and Kansu. The Chinese wolf-hound. The Tibetan mastiff. Tombdogs. British presents of mastiffs to the East. Records of Tibetan Mastiffs. Hydrophobia. 


\section{CONTENTS}

\section{CHAPTER V. \\ THE CHINESE LION.}

The lion not indigenous. Its popularity due to the introduction of Buddhism from India. The lion in captivity in China. Origin of lion-worship. The lion in Indian Buddhism. The lion in Foism. The lion in Lamaism. Description of the Lamaist lion. The spirit-lion and the lion-dog. Buddhist lion-stories. Chinese artistic idea of the lion. The lion in heraldry. Pp. go-III

\section{CHAPTER VI.}

\section{SYMBOLISM OF THE BUDDHIST AND LAMAIST LION.}

The lion symbolic of Buddhism's power of subjection over animal passions. Lion-masques in China and Japan. The Buddhist lion a spirit-beast. Its connection with Egyptian mythology. Curious superstitions in connection with it. Its possession of certain characteristics of Buddha.

Pp. I 12-122

CHAPTER VII.

\section{HISTORICAL REFERENCES TO DOGS OF PEKINGESE TYPE.}

Ancient Chinese small dogs. Early Chinese trade with Europe. Importation of pet dogs during the T'ang Dynasty. The Lo-Chiang or Pug dog. References to pet dogs during the Sung, Yuan and Ming Dynasties. Relations with Europe during the latter Dynasties.

Pp. $123-142$

\section{CHAPTER VIII.}

\section{EVOLUTION OF THE PEKINGESE TYPE.}

The first imperial pet-dogs not lion-dogs. First mention of lion-dog in the Sung Dynasty. Maltese dogs. Reason for popularity of "lion-dogs" at the Manchu Court. Increase of popularity up to the Tao Kuang period. First recorded importation to Europe. Dogs of the late Empress Dowager.

Pp. I $43^{-1} 54$

\section{CHAPTER IX.}

\section{POINTS OF THE [CHINESE PEKINGESE TYPE.]}

Importance of head-characteristics. Two types of head in China. Head colours. Nose. Eyes. Tongue. Size of dogs. Mouth and cheeks. Bodydevelopment. Legs. Specialisation of Pekingese breeds during Tao Kuang period. Coat. Colour. Albinos. The spot. Spectacles. Special markings. Docking of tails. xii 


\section{CONTENTS}

\section{CHAPTER X. \\ THE CHINESE PUG.}

Probable early introduction into Europe. Popularity of pugs in Europe. Possible origin in Szechuan. The Lo-Chiang dog. Its elasticity of skin. Forehead wrinkles. "Button" ears. Tail.

\section{CHAPTER XI. \\ THE “JAPANESE" DOGS.}

Introduction into Japan from China. European intercourse with Japan. Early Portuguese, Dutch and British trade. Possible Eastern origin of the King Charles spaniel. First recorded importation of Japanese dogs. Pp. 172-180

\section{CHAPTER XII.}

THE CHINESE LION DOG.

Tibet. Historical notes. The name applied by the Chinese to any longcoated dog. Presentation of lion-dog by the Tibetans to the Manchu Emperors. The European lion-dog. Two varieties of lion-dog in China. Their characteristics.

\section{CHAPTER XIII.}

\section{TOY DOGS IN CHINESE ART.}

Paintings on porcelain. Pictures mostly modern. Shen Chen-lin. Typepictures. Paintings mostly conventional. Pictures always full of symbolism and usually designed to convey wishes of good fortune. Examples of the wishes conveyed.

Pp. I 88-I 95 



\section{LIST OF ILLUSTRATIONS}

\section{IN COLOUR}

Modern Pekingese Dog, Shen Chen-lin. (Frontispiece)

To face page

Hunting Scene, Ch'ien Lung Period

Hunting Scene, Ch'ien Lung Period

Hunting Scene, Ch'ien Lung Period

60

Painting from a Scroll of a Hundred Pekingese Dogs, Tao Kuang Period, after Tsou Yi-Kwei, K'ang Hsi Period

Pekingese Dog, from an Imperial Dog Book. Painter unknown

$80 \& 81$

White Peringese, from an Imperial Dog Book. Painter unknown

Pekingese Dog, By Tsou Yi-Kwei, Vice-Minister of Board of Rites, FROM AN IMPERIAL DOG BOOK

Chinese Pug, from an Imperial Dog Book, 'Tsou Yi-Kwei, K'ang Hsi PERIOD

\section{IN BLACK AND WHITE}

Altar of Erh Lang, Pering

Chinese Dog Breeder, Lung Fu Ssu Market, Peking

Relief Band on Vase, Hsiao T'ang Shan

Relief Band on Vase, Han Period

Kansu GREyHOUNDS

Mastiff Tomb-Dog in Terra-Cotta, 'T'ang Period

Kansu Greyhound

Chinese Royal-conted Greyhound

Pottery Mastiff, in side and front view, Han Period

Lamaist lion (Male), Bronze, Yung Ho Kung (Lama Temple, Peking), Ch'ien Lung Period

Stone Lamaist Lion, Tien an Men

The Animal World Reverencing a Sacred Tree, Relief from East Gate,

SANChI (INDIA), ABOUT I 40 B.C.

Ming Seal

Bronze Lion, Sung Period

Ming Seal

Bronze Lion, Ming Period

Bronze Lion, Ming Period

IVORY Seal, Ming Period

Iron Lions before the Temple of Chiao Chun, God of Cookery, Peking, I665, K'ANg Hsi PeRIOD

LaMAist BRonze LiONS (MODERN)

Porcelain Lions Ming Period 


\section{LIST OF ILLUSTRATIONS}

Terra-Cotta Incense Burners, Ming Period

Lions in Lacquered Wood, Shop Front, Peking

Lions in Blackwood, Peking

Wooden Lion, Peking

Lion Figures Guarding a Corner of Pavilion-Roof, Summer Palace, Peking

Stone Pedestal of Pailou, Built by the Emperor Yung Lou, Ming

TOMBs, 'near Peking. Ethereal Lions with the Embroidered BaLI

AND TAPE-LIKE CORDS

Iron Lions, Yao Wang Temple, Peking

Lioness, Lama Temple, Peking

Lion, Lama Temple, Peking

Tibetan Lion (Female), K'ang Hsi Period. Italian Legation, Peking

Tibetan Lion (Male), K'ang Hsi Period. Italian Legation, Peking

Buddhist Lion-Masque, Peking, ig14

Buddhist Lion-Masque, Peking, igi 4

Japanese Lion-Masque Players in Porcelain

Buddhist Lion-Masque, Peking, igr 4

Bronze Incense Burner, Sung Period

SILVER SNUFF BOTTLE

PAIR OF IVORY OPIUM BOXES

Miniature Bronze Lion and a Corean "Purify Heart Pill" (Lion's MrLk PILL)

Wen Shu (Manjusri) Buddha Riding on a Lion (Huang Ssu, near Peking)

AN Imperial Dog Scroll, Painted By Miao Su-Chiün, Instructress in

Painting to the LATE Empress Dowager, Dated September, $189^{\circ}$

Painting, K’ang Period, Signed " Respectfully Presented." Leng Mei

Short-Conted "Pekingese," Modern

Back of Chinese Hand Mirror, Tao Kuang Period (about $185^{\circ}$ ), Painted ON SILK

Porcelain Dogs from Peking, Tao Kuang Period

Chinese Pug Dog, from an IMPERial Dog Book

Shen Chuan, by High Official of K'ang Hsi (early) Period

Porcelain Dogs from Peking, Tao Kuang Period

Painting by the Imperial Brush of Tzu Hsi, Empress Dowager, in the Ninth Year of T'ung Chim (1870)

NINE BUDDHIST LIONS

Porcelain Bowls with Eight Dogs, Tao Kuang Period (Pa-erh Kov)

Porcelain Snuff Bottles, Peking

"Ho Yun, 1820 Chiu Ching." Chin Shih, Toong Chü

Chinese Picture (Recent) used in Breeding

Cloth Lantern Cover. Shen Chen-lin

Silk Fan Signed “ Shen Lin," 19Oi, after the style of the Yuan Dynasty (1260 A.D.)

Chinese Fan

Chiv Shim Toong Chü Fan, Tao Kung Period

Lacquer Picture of Pekingese Dogs, Pah-erh Kou, K'ang Hsi Period, $1662-1723$

Panel Marked “Three Divided Flowers" Dog, Tao Kuang Period, after Lu Pao Shun, Painter of the Ming Period. Hsing Ke T’u xvi (HSING AND THE Pigeons) 


\section{LIST OF ILLUSTRATIONS}

LO-SZE DOG, "SHEN CHEN-LIN.'

Chinese Lo-sze or Pug Dog, Peking, I9I4

Chinese Lion Dog, Peking

Chinese Lion DOG

182

LION DOG, FROM AN IMPERIAL DOG BOOK

182

Lion Dog, from the Portrait of Dorothy Brereton, Second Wife of Sir Peter Leigh of Lyme, 1615

The LiON Dog

Chiu Shih Toong Chü, Probably Tao Kuang Period

FAN (Hsing KE T'U)

Porcelain SNuff Bottle

Amber Snuff Bottles with Interior Painting

Porcelain Snuff Bottle, Tao Kuang Period -

Chinese Bowl, Peking

Chinese Teacup and Cover, Tao Kuang Period

Porcelain Face-Powder Box from Peking

Porcelain Snuff Bottle from Pering, Shih-Tzu Kun Hsiu Chiu. Lion ROLLS EMBROIDERED BALL

Chinese Snuff Bottle ('Tai Shih, Shao Shih), Tao Kuang Period

Chinese Snuff Bottle (Tal Shih, Shao Shih), Tao Kuang Period

Chinese Snuff Bottles (Recent) San Yu T'u (Three Friends Pictures) 



\section{TABLE OF DATES}

B.c.

1122- 255. Chou Dynasty.

668-1

626.

Date of Assur-bani-pal (Assyrian) reliefs at Nineveh.

557. Birth of Buddha,

551. Birth of Confucius.

326. Alexander the Great invaded India after conquering Persia. Greek Art introduced into North India.

263-) Asoka, great patron of Buddhism, reigned in India .

200. Chinese capital was Hsianfu.

150. Approximate date of Hsiao T'ang Shan (Han period) reliefs.

A.D.

100. Jalandha Council. Buddhism divided into Northern and Southern.

300. Chinese capital was Lohyang.

420. Chinese capital was Hanking.

500. Buddhism preached by Chinese emperors.

552. Advent of Buddhism in Japan.

600. Chinese capital was Hsianfu.

618. Beginning of the T'ang Dynasty.

632. Buddhism first actively propagated in Tibet.

632- During this period Syrian, Christian, Nestorian and Assyrian Myths were 747. probably incorporated with Buddhism to make up Lamaism.

Tenth Century. There were Five Monarchies having capitals at Kaifengfu, Loh-yang, Ta Ming (Chi-li), Tai Yuen, Si-Ngan, and Peking at various periods.

1153. Chinese capital was moved to Peking.

1206-) Yuan (Mongol) Dynasty.

1253. Kublai Khan went to Tibet and brought back Lamaism

1628. ${ }^{168-}$ Ming Dynasty.

1644. Capture of Peking by the Manchus.

1662. Chinese Emperor K'ang Hsi came to the throne.

1723. Chinese Emperor Yung Ching came to the throne.

1736. Chinese Emperor Ch'ien Lung came to the throne

1793. Lord Macartney's Embassy to Peking.

1796. Chinese Emperor Chia Ch'ing came to the throne.

182r. Chinese Emperor Tao Kuang came to the throne.

1851. Chinese Emperor Hien Feng came to the throne.

1862 Chinese Emperor Kuang Su came to the throne. 



\section{CHAPTER I}

\section{EASTERN DOGS IN EARLY TIMES}

$7 \mathrm{HE}$ dog is believed, on evidence furnished by cave deposits, to have been introduced into Europe by neolithic peoples,* and to have been about the size of an ordinary shepherd's dog. $\dagger$

Geological research being in its infancy in China, it is too much to hope that similar information as to introduction of the dog into China will become available for some time. It is known, from literary sources, that the Chinese has been an agricultural race from its earliest days. It has always considered agriculture to be the root of its existence. It must, however, have been to some extent pastoral, though the valley of the Yellow River, in which the Chinese first settled, was probably well wooded at the time of arrival. Dogs were, no doubt, used for the defence of the home, for the herding of sheep and cattle, and for the chase.

In Japan geological research has been assisted by scientific examination of numerous dolmen and lake deposits similar to those found in England. The well-known writer, Brinkley, states that the early Japanese were derived from two swarms of colonists, both coming from Siberia, their arrival being separated by a long interval, the first cave-dwellers and the second the Ainu, who used stone implements and practised cannibalism. Among the amusements confined to men,

" Professor Boyd Dawkins, "Cave Hunting," pp. 256-7.

† Professor Rolleston, " Scientific Papers and Addresses," p. 522. 


\section{DOGS OF CHINA AND JAPAN}

cock-fighting and hunting were most practised. Large tracts of the country were still unreclaimed, deer and wild-boar abounded. These were driven by beaters into open spaces, there to be pursued by men on horseback with bows and arrows. In the fourth century the pastime of hawking was introduced. It came from Korea, a king of that country having sent a present of falcons to the Emperor of Japan.*

One theory as to the evolution of domestic dogs is that they were tamed at approximately the same period by several branches of the human race from the local wolf or jackal, and that to this must be traced the fact that in certain areas the native dog resembles the local wolf. Modern geological research, however, indicates that certain races of early man had no domestic dogs. According to Professor Geikie, $\uparrow$ the dog was not part of the indigenous fauna of Europe in Palæolithic times, and was introduced in Neolithic times by tribes who migrated, probably from Central Asia, into the European continent. Similarly the domestic cat arrived in England only at a period which was very late, in Saxon times. In early Neolithic or late Palæolithic times certain tribes which were in contact with the jackal-like $C$. mikii of the period, in an environment which favoured co-operation in the chase, captured the young of that animal, and because of the human ability to throw stones, to tie knots, and to use sticks, established such an ascendancy as to take full advantage of canine possibilities as watchers, as destructors of refuse, as food in time of need, and as assistants in the scenting out and pursuit of game. The tribes which first domesticated the dog were probably the first to domesticate the sheep and the ox. Geologists place the first known human remains as dating from at least 400,000 years B.C. Consequently,

" "Japan and China," vol. i, Captain F. Brinkley.

† "Text-book of Geology," vol. ii. p. 1356 . 


\section{EASTERN DOGS IN EARLY TIMES}

there was plenty of time for the race which first made progress in the domestication of the dog to take advantage of its discovery, which in those days was of a relative value far more important than all the discoveries of modern science, and possibly constituted a determining factor in early successful migrations, perhaps even in the migration of the Neolithics into Europe. C.palustris of the lake dwellings of the Neolithic period seems, according to Elliott, to be a slightly

\section{龙}

豺

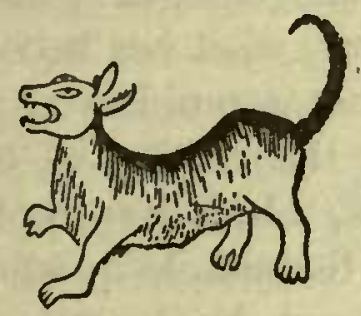

ENGRAVING OF A DOG (FROM MAO SHIH)



ENGRAVING OF A WOLF (FROM MAO SHIH)

From "Chinese Pottery of the Han Dynasty." By Berthold Laufer.

modified form of $C$. mikii. These partially domestic dogs of the neolithics would, no doubt, occasionally cross with the local wild dogs and wolves. "Prince Poutiatini discovered near Lake Bologoia in Russia a deposit of early Post-Glacial age which included a very dog-like wolf, which has been called after him $C$. poutiatini. The interesting point about it is the great elevation and width of the skull as compared with modern or extinct wolves. It is closely allied to the dingo of Australia and to the half-wild dog of Java ( $C$. tengerramus). Others suppose that an Indian wild-dog was the chief dog ancestor. Dogs of an Abyssinian species, of Egypt and of Majorca, are very like it. A curious point with regard to the further history of $C$. poutiatini under domestication is 


\section{DOGS OF CHINA AND JAPAN}

that his brain seems to have increased in size, undergoing much the same experience as that of man himself."*

The position as regards domestication of the dog in China is well summed up by Bertold Laufer: $\dagger$ " "We do not possess any historical records of any literature regarding the early domestication of animals, and therefore we should not expect to find such in China. The 'six domesticated animals 'of the Chinese-horse, ox, pig, sheep, dog, and fowl - existed in and with the nation when it appeared on the stage of history. They were there, and later historians could not explain their origin. They took them as one of the facts which cannot be accounted for, and as altogether too plain and natural to require discussion. In short, what has become a problem to our modern science was not a problem at all to them. Huang $\mathrm{Ti}$ is credited with the taming of bears, leopards, panthers, lynxes, and tigers, which he employed in battle against his adversaries ; but the simple question of training dogs remained untouched even by legend. The dog has doubtless been a constituent of Chinese culture since most ancient times, which is all that we are able to state with safety. The question as to who were the domesticators of the dog in Eastern Asia must naturally remain unanswered, at least from the standpoint of history."

Laufer describes and figures $\ddagger$ a bronze "tazza" of the Chou dynasty, upon which are engraved animals to the number of one hundred, including dogs. This is believed to be the oldest representation extant of dogs in China. Unfortunately the "tazza" is small in dimensions, and the drawings, though of artistic value, are imaginative and probably defective as accurate representations of the dogs of the period. The dogs figured appear to be of two or, perhaps,

" "Prehistoric Man and his Story," C. F. Scott Elliot, p. I97.

$\dagger$ "Chinese Pottery of the Han Dynasty," Laufer, p. 251.

$\ddagger$ P. I50. From an engraving in the "Hsi ch'ing ku chien," Book 29, p. 26. 


\section{EASTERN DOGS IN EARLY TIMES}

three kinds : one, diminutive, short-tailed, with erect ears ; another, long-bodied and long-tailed, long-legged, also with erect ears ; and a third of sturdier build, also long-tailed, and with erect ears.

It has been remarked by zoologists that the semidomestic dogs of the early inhabitants of many regions of the earth closely resemble the wolf races of the same regions, with these differences, that the domesticated dog is able to bark, while the wolf is able only to howl, and that in the wolf the position or form of the eye is oblique, while the dog has a circular pupil. The wolf is found throughout China. Very few specimens, however, have been secured,


and the Chinese races have never been studied by scientists. Similar remarks hold good for the wild dog, or "tsai-kou" of the Chinese. Two varieties of the wild-dog (C. alpinus) occur in China, one from the Tibet-Kansu borderland, the other from the Manchurian forests. They are closely related to 


\section{DOGS OF CHINA AND JAPAN}

the red dog of the Deccan.* The race is found in many parts of China. In size and build it is smaller than the common Chinese grey wolf. Its coloration is almost as varied as that of the domestic dog. In Yunnan Province as many as two or three individuals differing in colour have been seen near one village at one time in winter. It is not known to form packs, and is rarely seen in summer. Its cry resembles the howl of the domestic dog.

Among the Aryans the shepherd's dog, the house-dog, and the vagrant dog, comparable to the homeless begging friar, were specially protected by religious ordinances. The keeping back of their food or the giving of bad food to them was a crime punishable with many stripes. "For it is the dog, of all the creatures of the good spirit, that most quickly decays into age, while not eating near eating people, and watching goods none of which it receives. Bring ye unto him milk and fat with meat; this is the right food for the dog." †

"Whenever one eats bread one must put aside three mouthfuls and give them to the dogs ... for among all the poor than is none poorer than the dog." $\ddagger$

A further remark by Berthold Laufer deals with the possible wolf-origin of certain breeds of Chinese dogs :

"Most interesting in this connexion is a passage in the 'Tso chuan,' $\$$ 'To the Jung and Ti, the wolf is not an object of dislike,' by which is meant, apparently, that the wolf was not dreaded by these presumably Turkish tribes, and was accustomed to live in the neighbourhood of human dwellings.

- Sowerby, Journ. N.C.B.R.A.Soc., vol. xlvii.

$\dagger$ Zend Avesta, "Sacred Books of the East," vol. iv., p. 158.

\pm Saddar, 3 I ; Hyde, 35 .

\$ Given in the "Mao shih ming wu t'u shuo" (Book II, p. 3), under the description of the wolf, where again it is quoted after the book of Hsing Ping (932-10ro): Giles, "Biographical Dictionary," p. 296.

6 


\section{EASTERN DOGS IN EARLY TIMES}

This reminds us of Jäschke's remark, that the Tibetan wolves, where more numerous-as, for instance, in Spiti-commit ravages among sheep, but are otherwise not much dreaded by man, and, like the wolf in general, they are easily tamed. If we compare in the above-mentioned book, 'Mao shih,' etc., the picture of the wolf with that of the dog (mang*), a striking resemblance between the two is noticeable as regards shape of head, mouth, and body, legs, claws, tail, and hairiness. The mang is mentioned as early as the 'Shih king,' and must therefore have been known to the Chinese at an early date. It now seems questionable whether the Tibetans are to be looked upon as the trainers of the mastiff; if not, rather ancient Turkish tribes tamed the wolf-an animal with which they were always quite familiar, and which played an eminent rôle in their tribal traditions and creation myths $†$ at a much earlier period. Of the fact that the dog in general was known in the South-Siberian bronze age, we possess wellauthenticated archæological evidence in a bronze plaque representing a hunter accompanied by two dogs. In this connexion it is worthy of note that a fierce kind of dog, called p'i ngan (usually translated 'bull-dog'), whose picture is painted on the doors of jails because of his ability as a watch$\mathrm{dog}$, is said to originate from the land of the Turks.

"The "Shuo wen" (A.D. IOo) gives the following names of dogs, and their definitions :

Hsien (or lien) is a black dog with yellow chin.

Mang is a dog with plenty of hair.

Hsien (character slightly different from above) is a dog that barks incessantly.

Ao is a dog that knows man's heart, and can accordingly be utilized. (See Laufer, p. 253.)

The "Erh Ya" states that a dog with long snout is called hsien or lien; one with a short snout, hsieh hsiao. According to the 'Shih King,' both are hunting dogs (Couvreur's edition, p. 134). The "Erh Ya" also states that the chao is a dog of great strength.

† H. Vambéry, "Die primitive Cultur des turko-tatarischen Volkes" (Leipzig, 1879), pp. 197-98. 


\section{DOGS OF CHINA AND JAPAN}

"Other evidence pointing to the same fact is found in the peculiar ' dog of the kind which is found with the barbarians Ti,' mentioned by Ssu-ma Ch'ien. And if the country of Lü, which sent the hound ao, was a branch of the Western Jung, everything is indeed apt to show that these large extraordinary dogs, including the mastiffs-if the term mang may be identified with the latter-came from Turkish regions. It is noteworthy, too, that, according to the dictionary 'Shuo wen' (A.D. 100), the land of the Hsiung nu (Huns) possessed a special kind of dog, called chiao, with large mouth and black body, which characteristics are essential to the mastiff. For the rest, the definition of the chiao appears as a fabulous animal in the 'Shan hai king': 'On the nephrite hills there is an animal of a shape like a dog, striped like a panther, and with horns like an ox; it is called chiao; its voice is like that of a barking dog; in the country where it appears dogs will be abundant.' In a book, 'Jui ying t'u,' occurs now the interesting passage that the Hsiung nu offered panther-dogs with pointed mouth, red body, and four feet. Whether these latter animals were mastiffs or not-red colour occurs with them, in fact-it is evident that the Hsiung nu possessed extraordinary dogs, which arrived also in China."

The chase was of prime interest to the ancient Chinese, and there are numerous references to sporting dogs in their earlier literature. The first Emperors known to history organized hunting expeditions, with levies from every district, four times a year, chiefly with a view to training their men for war. There are, unfortunately, few descriptions of the breeds of hunting dogs used, yet it is known that the Emperors set great value on them. The "Tribute Decrees for the four Quarters "* records that a Grand Councillor of the Emperor T'ang, who lived about 1760 B.c., counselled his master to " "Yuan Chuan Lei Han," vol. cdxxxvi, " Dogs," second part. 


\section{EASTERN DOGS IN EARLY TIMES}

take from the Due South (of Honan) country "square" dogs as tribute. The Chinese monarchs of the period, perhaps, shared the zoological tastes of the potentates of Assyria, such as Tiglath-Pileser, who collected all kinds of beasts for his menageries at a period about 1200 B.c. Dogs, both large and of small size, are known, from the Egyptian bas-reliefs, to have existed in even earlier days.* $\dagger$ They also existed in South America. I There is nothing to indicate whether the Chinese "square" dogs were large or small.

The Books of Shang mention the sending as tribute of a hound or hounds, perhaps, according to Chinese commentators quoted by Legge, bloodhounds, called " ao " (pronounced as ough in bough), "knowing the mind of man and capable of being employed " by the wild tribe of Leu in the West " by way of instruction" to the young king, King Woo, probably about I 20 B.C. Commenting on this fact the Chinese classics laid the foundation upon which Chinese foreign policy was destined, for thirty centuries and more, to be based : "A prince should not do what is unprofitable to the injury of that which is profitable, and then his merit may be completed. He should not value strange things to the contemning of things that are useful, and then his people will be able to supply all his needs. Even dogs and horses which are not native to his country he will not keep ; fine birds and strange animals he will not nourish in his kingdom. When he does not look

" " Helps to Study of the Bible," plate lxx.

$\uparrow$ Dr. S. Birch believed the spaniel to be identified on the early Egyptian monuments. M. B. Wynne, "History of the Mastiff," 1886, p. 37.

f "Dogs were used for hunting, and it is noteworthy that remains of three kinds of dog, all differing from that of Europe, have been found on the coast. The largest of these was an animal of medium size with slender head and legs, and was probably used for watching the house (and, in the interior, the herds), and for hunting. The second was a short-legged dog, somewhat resembling a dachshund, which, to judge from a vase-painting, was also used in the chase. The third was a kind of pug, probably kept as a lap-dog." "South American Archæology," Joyce [Peru], Macmillan, 1912. 


\section{DOGS OF CHINA AND JAPAN}

on foreign things as precious, foreigners will come to him; when that which is precious to him is worth, his own people near at hand will enjoy repose." *

Nothing is known of the situation of the Leu country, and the dogs are not described by any reliable Chinese authority. Other Chinese commentators state that these dogs were "Four feet (ancient feet, that is) high," but the authority of such commentators, who wrote in some cases hundreds of years after destruction of the original text, is doubtful. Laufer considers that the Leu were one of the numerous branches of the Turkish tribes.

German writers $\uparrow$ have gone so far as to base upon this record a totally unjustified statement that the dogs of Leu were Thibetan mastiffs, and on this slender testimony have built up an elaborate theory to the effect that the Chinese dog is of Thibetan origin, and that the canine race in China is derived from Western countries. These German writers have omitted to take into consideration the fact that up to the seventh century A.D. there was no such country as Thibet, and the people who occupied the region at present called by that name consisted of unknown nomad tribes, having no recorded history, for the foundation of civilized monarchy in Thibet was laid only in A.D. 652. They were steeped in barbarism, and devoid of any written language.

Chavannes, quoting from the "Annals of Ssu-ma Ch'ien," states that the Emperor Chou Hsin (I 154-1123 B.C.) of the Yin dynasty, in ill repute on account of his extravagance and debauchery, maintained a great number of dogs, horses, and rare objects, and filled his palaces with them.f

"Legge's " Chinese Classics," vol. iii, Part V, Book V.

+ Oscar Albrecht, "Zur Altesten Geschichte des Hundes," Munschen, 1903, p. $5^{8}$; C. Keller, "Die Abstammung des Altesten Hausthiere," Zurich, 1902, p. 74 ; Max Sieber, "Der Thibethund," Winterthur, 1897.

‡ Chavannes, "Les memoires historiques de Se-ma Ts”ien," vol. i, p. 200. 


\section{EASTERN DOGS IN EARLY TIMES}

An official record * of the Chow Dynasty (about 1000 B.C.) remarks, "From the Southern (of Shansi) States the yearly tribute included amber, pearls, ivory, rhinoceros' horns, kingfishers' feathers, cranes, and short dogs." The nature of the other products clearly indicates that these dogs came from South China, though it is just possible that some of them may have originated from more distant countries, travelling by the sea route.

Under primitive conditions the dog was, no doubt, more than the friend of man. He was his ally, useful for protection, necessary alike for the guarding of his herds and the taking of his prey. It was only when man, by agriculture and his other arts, had improved his position sufficiently to become independent, that he began to give the dog a bad name, certain religions, such as the Jewish and Mohammedan, banning the race as abominable and unclean. In the whole of Jewish history there is not a single allusion to hunting with dogs. Jewish prejudice was, no doubt, largely due to the exaggerated idolatry practised to the race from time immemorial by the Egyptians, hereditary enemies of the Jews.

The beneficent dog-headed divinity Anubis, originally a jackal-type, and later represented by the dog as his emblem, was among the Egyptians, servant, messenger, and custodian of the gods, lord of the cemetery and of the underworld. Temples were consecrated to him throughout the land, and his image was borne in all religious ceremonies. This dogworship was not confined to Egypt, for the Greeks adopted it, and a Roman emperor carried the god Anubis in the feasts of Isis. Herodotus, speaking of the sanctity in which some animals were held by the Egyptians, to whom the appearance of the watchful dog-star Sirius, "Latrator Anubis," above the horizon was the signal that their flocks had to be removed " "Yi Chou Shu." 


\section{DOGS OF CHINA AND JAPAN}

from Lower Egypt and the coming floods of the Nile, says that the people of every family in which a dog died shaved themselves-their expression of mourning-adding that this was the custom of his own time.

Very fine and clear representations of the sporting dogs used in hunting the wild ass by the monarchs of Assyria are found in the bas-reliefs of Assur-bani-pal, dating from 668626 B.c. Clay models of the dogs of this monarch also exist.*

In Ethiopia not only was great veneration paid to the dog, but the inhabitants used to elect a dog as their king. It was kept in great state and surrounded by a numerous train of officers and guards.

Pythagoras, after his return from Egypt, founded a new sect in Egypt and S. Italy, teaching, with the Egyptian philosophers, that at the death of the body the soul entered into that of various animals. At the death of any of his favourite disciples he would hold a dog to the mouth of the man in order to receive the departing spirit, saying that there was no animal which could perpetuate his virtues better than that quadruped. $\dagger$

The Parsi religion, whose priests ruled Persia from a period many centuries before the Christian era until overthrown by the second successor of Mohammed, devoted the whole of one of its sacred books, found in the Zend Avesta to the dog. To the Magi of this fire-worshipping religion the Rabbi's and Mohammed owe much of their thought. To a reaction against its extravagant dog-reverence coupled with that of ancient Egypt is, perhaps, due the abhorrence in which the dog is held by Saracen and Jew alike. This veneration held by the Aryans for the canine disguise attributed to some of their divinities, appears to throw light upon the race's

$$
\text { " "Mesopotamian Archæology," by Percy S. P. Handcock, I91 } 2 .
$$




\section{EASTERN DOGS IN EARLY TIMES}

importance to man in those early days. "The dog, O Spitama Zarathustra! I, Ahura Mazda, have made, self-clothed and self-shod, watchful, wakeful, and sharp-toothed, born to take his food from man and to watch over man's goods. I, Ahura Mazda, have made the dog strong of body against the evil-doer and watchful over your goods, when he is of sound mind. If those two dogs of mine, the shepherd's dog and the house-dog, pass by the house of any of my faithful people, let them never be kept away from it. For no house could subsist on the earth made by Ahura, but for those two dogs of mine, the shepherd's dog and the house dog." The sacred writer lays down special injunctions for the breeding of dogs, the care of young dogs, and for the general treatment of the race. "If the bones stick in the dog's teeth or stop in his throat, or if the hot food burn his mouth or his tongue, so that mischief follows therefrom, and the dog dies, this is a sin that makes a man a Peshotanu." * The reasons for which the canine race has the characters of a priest, a warrior, a husbandman, a strolling singer, a thief, a wild beast, a courtezan, and a child are explained at length. The holy writer explains that at death a dog's ghost passes to the spring of the waters and that there, out of every thousand males and every thousand females are formed a male and female water-dog. To each of the water-dogs, the holiest of all dogs, was ascribed an extraordinary measure of sanctity. So extravagant was the penalty allotted on paper by the Zoroastrians for the murder of a water-dog that it has been doubted whether their legislation ever existed as real and living law. The penalties imposed for such a murder included the infliction of twenty thousand stripes, the carrying of a similar number of loads of wood, the killing of ten thousand snakes, ten thousand cats, ten thousand tortoises,

* Zend Avesta, "Sacred Books of the East," vol. iv, pp. 160, 163, 173 . 


\section{DOGS OF CHINA AND JAPAN}

twenty thousand frogs, the same number of ants, ten thousand earthworms and horrid flies. The culprit was to "godly and piously give to godly men " a set of priestly instruments, a set of war implements, of husbandmen's implements, the price of a stallion in silver, and of a camel in gold, a rill of running water, the depth of a dog and the breadth of a dog, a house with ox-stalls, goodly beds with cushions, a virgin maid, fourteen head of small cattle. He was to bring up twice seven whelps, and to throw twice seven bridges over canals.*

Confucius, the chief of China's sages, who was born in the year 55 I B.C., favoured simplicity, and was the enemy of all hypocrisy such as that which would not allow the price of a dog to be brought into the House of the Lord. $f$ Confucius " smiled, and exclaimed, "True, true,' in amusement" at the aptness of the simile when likened to a homeless dog at the gate of the City of Chen.f Literary Chinese will to this day, spontaneously borrow similar allusions from the classics. In introducing his son a scholar will use a strictly classical term which can only be translated by some refined English phrase, finally reducible to "puppy." Another, in offering his services, will state his willingness to be the "dog and the horse " of his master.

The Province of Shantung, of which Confucius was a native, appears always to have been famous for its dogs. "In first-class houses there are fierce dogs that watch the doors to the halls of singing-girls. Men who are not regular customers are not allowed to enter unceremoniously. If they enter, the dogs bite them to death. Their warning is like that of a spirit, their fierceness like that of a tiger. They are dogs from Meng hai in Ts'ao chou." §

"Zend Avesta, "Sacred Books of the East," vol. iv, p. 166.

+ Deuteronomy xviii. 18 . I Shih Chi.

$\$$ A prefecture in Western Shantung. Ko chih ching yuan and T'u shu chi ch'eng, vol. dxciv, Laufer, p. 265. 


\section{EASTERN DOGS IN EARLY TIMES}

Reverting to the dog or dogs ao of Leu, whose arrival caused the enunciation of a foreign policy which has had an important bearing upon the development of the whole Chinese race, we find that numerous fanciful pictures of it have been produced by painters of the Sung (A.D..960) and Ming (A.D. 1368) dynasties. It is the most famous dog in Chinese history. The incident was frequently quoted to emphasize the necessity of study of statecraft upon later emperors, and to discourage over-affection for the four luxuries in whose possession these primitive rustic potentates were apt to take the greatest pride -namely, gold, jade, dogs, and horses. So addicted to the pleasure of the chase were these early "sporting " emperors, that all references to it had to be severely banned at the Imperial Audiences: "At Audiences let no reference be made to matters pertaining to the dog and the horse." * The learned Commentator adds " the dog and the horse are of minor importance, and not subjects worthy of discussion at Audiences." It is to be feared that in certain cases an emperor was somewhat inclined to hold the affairs of state merely "something better than his dog, and a little dearer than his horse."

His views may be compared to those of Julius Cæsar: "One day in Rome, Cæsar, seeing some rich foreigners nursing and petting young lapdogs and monkeys, inquired whether in their parts of the world women bore no children; a truly imperial reproof to those who waste on animals the affection which they ought to bestow on mankind." $\dagger$

The paucity of detail in reference to dogs down to the period of the Emperor Chin Shih may be in part ascribed to the destruction of much valuable material in his holocaust of Chinese literature (255 B.C.), which, no doubt, accounts in

* "Book of Rites," vol. i (written about the seventh century B.c.), vide "Commentaries of the Sung Dynasty."

+ Plutarch's " Life of Pericles," A.D. 40 ; "Toy Dogs," by the Hon. Mrs. Neville Lytton, p. 268. 


\section{DOGS OF CHINA AND JAPAN}

large measure for the poverty of later writings in matters dealing with the early history of Chinese dogs. Just as King James" "Counterblast" against tobacco-smoking forbade the writers of that period-notably Shakespeare--to mention the weed which flowed in wreaths of smoke-thus depriving us of much of the early history of Raleigh's discovery-so Chin Shih's ban on all things literary has left us in ignorance of many an incident which would otherwise now stand chronicled.

Short-mouthed dogs are referred to as having existed in the time of Confucius.* The Sage mentions the dog incidentally in exhorting his disciples to salvage economy. He says: "I have heard that the discarded hangings of the chariot may be used to wrap the beloved saddle-horse for burial, and that the torn awning (or chariot umbrella) will serve to cover the dear house-dog in his grave." $\dagger$

About 500 years B.C. it is recorded that dogs were used in the kingdom now represented by the Province of Shansi for sporting purposes. Some of these were probably small dogs, for it is mentioned that after the day's sport, one kind of dog followed its master's chariot, while " those having short mouths were carried in the carts." $\ddagger$

It was only as late as the Roman occupation that specific knowledge of the five races of dogs existent in England was secured. These are believed to have been the house-dog, the greyhound, the bulldog, the terrier, and the slow-hound. The British dogs are said to have been in great demand in Rome, both for hunting and for the sports of the amphitheatre, $\S$ and a special officer was appointed for procuring them.

Similarly, it was only at the end of the first century of our era that the Chinese books became a little more specific as

" "Erh Ya."

$\dagger$ Li Chi. Pan Kung.

† "Erh Ya."

$\S$ Notes and Queries, I900, vol. v, p. 524 . 


\section{EASTERN DOGS IN EARLY TIMES}

to the nature of the dogs mentioned. They speak of some of them as being called by the name "Pai," which later Chinese authorities explain as referring to a very small "shortlegged " * and " short-headed " $†$ type of dog, which belongs under the table.f The Chinese table of the period was low, and those round it sat on mats.

From this period onwards, many of the Chinese emperors seem to have taken greater interest in small dogs. The Eastern emperors appear to have been led, partly, perhaps, through feminine influence, to extremes unsurpassed by the Merry Monarch himself. It may here be noted that references to dogs in Chinese history are often made with the object, not of recording details to throw light upon the manners of the period, but as obiter scripta to illustrate effeminacy and want of care in statecraft on the part of the ruler.

There was a similar tendency among Japanese historians. "In the days of Takatoki, the ninth representative of the Hojo family (who reigned at the end of the thirteenth century) a new atmosphere permeated Kamakura. Instead of visiting the archery-ground and the fencing-school men began to waste day and night in the company of dancing-girls, professional musicians, and jesters. The plain simple diet of former days was exchanged for Chinese dishes. Takatoki kept thirty-seven concubines, maintained a band of two thousand actors, and had a pack of two thousand fighting-dogs." Twelve great fights took place every month, and when the champion of the dogs, fancifully described as being in some cases as big as oxen, were led through the streets, people doffed their head-gear, and even knelt down in reverence.§

The official history of the Han dynasty states that the

" "Chien Lei Han."

I "Shuo wen" of Hsu Shen.

† "Kwong Yun" by Ch'en.

$\S$ "Japan and China," vol. ii, p. 13, by Captain F. Brinkley.

|| "Hou Han Shu," vol viii. Quoted by Pei Wen Yun Fu. 


\section{DOGS OF CHINA AND JAPAN}

Emperor Ling $\mathrm{Ti}$ (A.D. I68-190) was both foolish and vicious. He took to driving a chariot with asses four-in-hand in his capital, the result being that his faithful subjects followed the Imperial example to such good purpose that the price of asses became equal to that of horses. He sold rank and official positions. From the Chief of a Province whose annual salary was two thousand piculs of rice he would require twenty thousand strings of cash in advance, but, if poverty forbade, he was willing to accept a promise of twice this amount at the completion of the term of office. He kept in his Western Garden at Lo Yang (Honanfu) a dog of which he was extremely fond, and to this animal he gave the official hat of the Chin Hsien grade-the most important literary rank of the period-as well as an official belt. "The hat was 83 inches high in front, $3 \frac{3}{4}$ inches high behind, and to inches broad."

Nearly all the dogs which were reared by the Emperor were given the rank of K'ai Fu (approximately that of a Viceroy); others that of Yi Tung (a rank probably equivalent to the present post of Imperial Guardian). The females were given the ranks of the wives of the corresponding officials. These dogs were guarded by soldiers and fed on the best of rice and meat. For their beds they were given the choicest carpets.*

The book from which this reference is taken proceeds gravely: "This had the effect of likening the high officials to dogs, and so was a bad practice."

The literati could not forgive this fatuous bestowal of literary rank upon dogs, however intelligent. They stigmatize Ling Ti as weak, indolent, and content to leave his affairs of state to the chief eunuchs.

The Emperor Fei Ti (A.D. 973-977) of the Southern Sung Dynasty appears to have got into similar bad odour with the * "Tung K'ao," by Ma Tuan Lin of the Yuan Dynasty. (Date of book, A.D. I3 I9.) r8 


\section{EASTERN DOGS IN EARLY TIMES}

literati, for they record that he was addicted to drunkenness in temples, and was given to stealing dogs from his subjects.* His nightly prowlings, after the manner of Khalif Haroun-alRaschid, in later days led to his death, for, returning to the palace one night in an inebriated state, he was followed and murdered by one of his generals.

* Yu Pi T'ung Ch'ien. 


\section{CHAPTER II \\ DOG-LORE AND SUPERSTITION}

$T \mathrm{~N}$ parts of Europe, temporary isolation and rise in the cost of living have, from time to time, caused the flesh 1 of the horse and other animals little known to the arts of cookery to be used as the food of man. In China, poverty, due to over-population, has existed from time immemorial, and it is not surprising to find, in the stories of early foreign travellers, confirmation of the wide-spread belief that, notwithstanding the nation's high degree of civilization, dogflesh has been used as human food in that country. The Arab traveller Ibn Batuta wrote, about A.D. I342, "The flesh of swine and dogs is eaten by the Chinese pagans, and it is sold publicly in their markets." * Fernam Mendez Pinto, a Portuguese whose remarkable adventures are recorded by Purchas, wrote two hundred years later, "We saw pennes full of little dogges to sell ... frogs, snakes, snailes, all being meate with them (the Chinese)." $\dagger$ " The ordinary and daily meals are made by the Chinese very early," writes another traveller, " for they have an opinion that if they should fast till noon some misfortune should befall them that day. They are not curious in their diet, for they eat all manner of flesh without difference, as well that of a horse as of an ox : they are great lovers of swine's flesh, which they praise as the most delicious of any, and is preferred by them before any

* "Cathay and the Way Thither," vol. iv, p. I Io.

† "Purchas his Pilgrimes," vol. xii, p. 109, Maclehose. 


\section{DOG-LORE AND SUPERSTITION}

other. But the more ordinary sort of people will feed upon any carrion, either of a horse, mule, ass, dogs, or any creatures." *

The Spanish priest Navarette, writing about twenty years later, reflects the point of view, in matters canine, of the European at a period when dog-fighting and bull-baiting were ordinary pastimes. "The Officer that carry'd me to the Metropolis assur'd me (and I had it from others before) that he eat for his Breakfast every morning 30 Eggs, and a Dog's Leg, and drank two Quartillos (it is about a pint and a half) of hot Wine. The good old man looked so fat and fair, it did a man good to see him. Infinite number of Dogs are eaten in China, they count their flesh delicate and nourishing, and have Butchers and Shambles where it is sold; but more in the Northern Provinces than in the Southern. It is comical to see what a multitude of dogs pursue these Butchers as they go along the Streets; I suppose the smell of the Dogs' flesh they carry about them provokes the other Dogs. When they go loaded with half a dozen or more Dogs to the Shambles, the sport is still better; for the noise those so carry'd make, brings out all the Dogs in the Town to take their parts, and attack their mortal enemy's. They also eat Horse-flesh, Buffalo, Cats, and Mice ; and other sorts. I myself eat of a Horse, Dogs, and Mice, and in truth I lik'd them very well." $\dagger$

The Mongolian tribes living in the Far North of ancient China ate dogs'-flesh, and as a means of trial by ordeal had a practice of drinking dogs' blood. Ysbrants Ides, $\downarrow$ a Russian Ambassador who travelled to China in 1692, remarks incidentally, "While in Peking I observed, at the door of a considerable Mandaryn, and a Great Officer, some persons

"John Ogilby's translation of Nieuhoff's "Embassy from the East India Company," I655, p. 172 .

+ "An Account of the Emperor of China," Navarette, p. 65.

I "Three Years' Travels from Moscow to China," by Ysbrants Ides, r7o6, p. 45 . 


\section{DOGS OF CHINA AND JAPAN}

flaying of a fat Dog; upon which I asked the Mandaryn, Wherefore that was done? Who answered, That it was a healthful sort of food, especially in Summer, it being very cooling." He remarks of the Tungus tribes that they eat cats and dogs, and figures the butchering of these animals near their tents, stating that "Very few of them are found without several dead young Dogs hanging near them." $\mathrm{He}$ also figures the Tungus trial by ordeal, which is described as follows: "The Waywode asked the Accuser if he would, according to the Tunguzian Custom, put the Accused to his Oath ? To this he answered in the Affirmative; after which the accused took a live Dog, laid him on the Ground, and with a knife stuck him in the Body, just under his left Foot, and immediately clapped his Mouth to the Wound, and sucked out the Dog's Blood so long as he could come at it ; after which he lifted him up, laid him on his shoulders, and clapp'd his Mouth again to the Wound in order to suck out the remaining Blood. An excellent drink indeed."

In a work dating from the beginning of the nineteenth century we read :

"We will not attempt, in a spirit of false delicacy, to conceal the fact that the lower class in China is in the habit of eating the flesh of the dog, the cat, the rat, etc.

"But that which must be more astonishing is that according to tradition and the witness of the learned, it appears that the Chinese actually classed ass and dog-flesh as butcher's meat at a period in which, as its population was numerically moderate, means of subsistence could not have been scarce. This was a difficulty which, for a considerable period, embarrassed Père Cibot, who spared no research in his endeavours to elucidate the point. At last he discovered in a celebrated work written for the instruction of the princes of the Imperial Family, that in ancient days three kinds of dogs were distinguished: the 


\section{DOG-LORE AND SUPERSTITION}

watch-dog, the hunting-dog, and the edible dog; but according to the description of this last, this pretended dog used as food is nothing but the otter, an animal which European naturalists have also included in the canine species." *

Father Cibot's authority is, no doubt, the remark of an early Chinese commentator dealing with a quotation from the "Book of Rites." He remarks that "dogs are of three kinds : hunting-dogs, watch-dogs, and those used for culinary purposes, commonly known as edible dogs." $\dagger$

The endeavours to relieve the ancient Chinese of the supposed stigma of eating canine flesh is more ingenious than convincing, for the otter is not commonly found in China, is not classed as a dog, and has no special reputation as a table delicacy. Nor is the otter an animal which readily lends itself to fattening. The "Book of Rites" further enjoins that all animal gifts offered on sacred occasions shall be in a fitting state of plumpness, and remarks: "When a dog is offered at the sacrifices of the ancestral temples it is to be called 'Kenghsien." "The commentator solemnly explains that "Kenghsien " is a soup made from a fat dog. Dog-flesh, on the other hand, is known by tradition to have been, from time immemorial, the food of man in China, and to have beenconsidered, under certain conditions, a delicacy. The Chinese have no cause to be unduly sensitive on account of the tastes of their ancestors, for, writing at the same time as Father Grosier, another author remarks : "In America, the flesh of the dog is eaten, and it is to be found commonly with other kinds of meat and game in the public markets. The ancients also reckoned a young and fat dog excellent food. Hippocrates classed it with mutton and pork. The Romans

" "Grosier de la Chine," 1819, vol. iv, p. 244.

t "Book of Rites," vol. $i$. 


\section{DOGS OF CHINA AND JAPAN}

admired sucking whelps, and sacrificed them to their divinities. The Romans thought them a supper in which the gods themselves delighted." *

Professor Boyd Dawkins, delving still deeper into the past, found evidence of the use of dogs'-flesh among the cavedwellers of Britain itself, and remarks that the large percentage of fractured bones of puppies implies that they found especial culinary favour among our prehistoric ancestors. $\dagger$

In Corea dog-flesh was on sale among the common butchers' meats, and enjoyed by the people, in 1882 . In the first month of the year, however, owing to religious scruples, no dog-meat was eaten. Griffis states that the people of Kokorai, $\neq$ from whom the Coreans are descended, held dogs in considerable honour and named their rulers after the domestic beasts, the horse, the ox, and the dog, etc. In Japan dogs are held in very little honour except the " chin" or Japanese spaniel. $\$$ It is a remarkable fact that though the Chinese and Corean partiality for dog-flesh has been noted by almost every close observer of their customs from early times, the Japanese appear never within historic times to have eaten this meat. In the light of the theory that the early Japanese were derived from two swarms of colonists both coming from Siberia, the first cave-dwellers and the second the Ainu, who used stone implements, the following remarks by Perry ॥ are of considerable interest, as they seem to suggest absence of the influence of megalithic culture, which appears to have tended to restrain from the use of canine flesh, from early Chinese development. "Several facts go to show that the whole group of notions concerning the relationship between

"Rees's" Cyclopædia," vol. xii, " Dog," r8rg.

+ Boyd Dawkins, " Cave Hunting."

\# "Corea: the Hermit Nation," Griffis, 1882, p. 267. \$Ibid., p. 52.

|| "The Megalithic Culture of Indonesia," Manchester University Press, 19I8, chap. $x x$. 


\section{DOG-LORE AND SUPERSTITION}

men and animals were introduced (into Indonesia) by the stone-using immigrants. For they appear to be more closely connected with animals than the indigenous peoples. The chiefs of Kupang in Timor are said to be descended from crocodiles." "The Khasi have certain food-restrictions. They do not, as a people, eat dogs or ordinary frogs." "The cat and dog are not eaten by the Kayan of the Mahakam river." "Among the Chiru no women may eat dog, which is also forbidden to the priests when killed for a sacrifice." "Dogs and salt fish are forbidden when rice is being transplanted, and dogs are forbidden during rice-harvest and epidemics."

The street-dogs, as remarked by Robert Fortune,* a botanist who visited Japan in I860, " appear to be of the same breed as the common Chinese dog, and both have probably sprung from the same stock." They were as much neglected as is the case in China to-day. "On a warm summer afternoon," he continues, "these animals may be seen lying at full length in the public highway, apparently sound asleep; and it was not unusual for our attendants to kick and whip them out of our road in a most unceremonious way. On many of them the marks of the sharp swords of the yakoneens were plainly visible, and everything tended to show, that if the dogs were regarded as sacred by some, the feeling fails to secure them from being cruelly ill-treated by the common people. It was not unusual to meet with wretched specimens in a half-starved condition, and covered with loathsome disease." His statements are confirmed by the remark of Lafcadio Hearn, that the condition of the Japanese dog is one thing which tells powerfully against beliefs about the influence of Buddhism upon the treatment of animals.

The dog has had his day in Japan, however. "We went by the place where publick orders and proclamations are put up,

- Kaempfer. 


\section{DOGS OF CHINA AND JAPAN}

not far from the ditch of the castle, where we saw a new proclamation put up lately and twenty shuits of silver nail'd to the post to be given as a reward to any body that would discover the accomplices of a murder lately committed upon a dog. Many a poor man hath been severely punish'd in this country, under the present Emperor's reign, purely for the sake of dogs." *

The Chinese three-character classic, to this day a schoolroom text-book, continues to instil into the schoolboy mind that the canine and equine races supply two of the six kinds of flesh edible by man. To this day, too, dogs closely resembling the foreign " chow" are bred in parts of Quangtung and Quangsi Provinces for culinary purposes. Black dogs are considered to be the most nutritious. "Flowery dogs" -those of mixed colour-are reputed to be the most palatable, those of yellow and white colour following them in culinary value. The puppies are fattened on rice, and killed at an age of about nine months. After removing the hair by scalding, the body is cut into six or eight pieces and boiled for about an hour. It is then fried in oil. The meat is cut into small pieces and cooked with dry mushrooms, preserved bean-cake, native onion, a little ginger, and water-chestnuts. The dish resulting is said to be exceedingly palatable, and to have the property of reducing fatigue due to sleeplessness. For this reason the dish was very popular with students in the provincial and national examinations of the Manchu regime, which were carried on continuously for several days.

Archdeacon Gray, $\uparrow$ writing in 1878 of the dogs'-flesh restaurants of Canton, states that in the city there were no less than twenty such places " where cooks may be seen standing in front of slow fires over which the flesh of cats and dogs is being cooked. Placards are sometimes placed above the door,

$$
\text { - Kaempfer. }
$$$$
\text { † " China," J. H. Gray, vol. ii, p. } 76 .
$$ 


\section{DOG-LORE AND SUPERSTITION}

setting forth that the flesh of black dogs and cats can be served up at a moment's notice. On the walls of the diningrooms are bills of fare. The following is a translation of one :

Cat's flesh, one basin ... Io cents.

Blăck cat's flesh, one small basin .. 5 cents.

Wine, one bottle $\quad . . \quad$.. $\quad$.. 3 cents.

Wine, one small bottle $\quad$.. $\quad$.. $\quad$ I $\frac{1}{2}$ cents.

Ketchup, one basin $\quad$.. $\quad$.. 2 cash.

Black dog's grease $\quad$.. $\quad$.. I tael 4 cents.

Black cat's eyes, one pair .. $\quad$.. 4 cents.

"The persons who frequent such eating-houses are respectable shopkeepers and artisans, and the sum which they pay for a good dinner is on an average 15 cents., or $7 \frac{1}{2} \mathrm{~d}$. I have occasionally seen poor men dining at these restaurants, but they form a very small proportion of the visitors. At Peking I found two or three shops in which dog's flesh was exposed for sale as food; and Dr. Williams has stated that dog hams are exported from the northern province of Shantung. At the commencement of summer a ceremony called A-chee, which consists in eating dogs' flesh is observed throughout the Empire by persons of all ranks. The Cantonese think that to eat the flesh of dogs is to act in opposition to the will of the gods, and on many Buddhist temples I have seen placards calling upon the people not only to abstain from the flesh of bulls, goats, and swine, but from that also of dogs, as these are the faithful guardians of their masters' homes."

The public marketing of dogs' flesh has been prohibited in Canton only from about the middle of 1915. It is exposed for sale openly in the butchers' shops in the suburbs to this day. In Quangtung Province, too, a dish said to have powerful protective properties against cold is made with a combination of the meat of snakes and cats, called by the 


\section{DOGS OF CHINA AND JAPAN}

figurative name of "Dragon-Tiger Soup." Hams cut from the dog may be eaten in some parts of China, but butchers' shops which sell the meat are now rare and of the poorest. Even the beggars who buy it shield their loss of "face " by calling the meat by the euphemistic name of "ground lamb" (ti-yang) as distinct from wool-sheep or hill-sheep (yang). The random foreign traveller will, however, have to fare far and make strict search before discovering a dish of dog-meat in China to-day.

Buddhism, the State religion in most parts of India during the early centuries of our era, was a form of belief which separated from the main stock of the Hindu religion based on the Brahmanical scriptures still professed by seventy per cent. of the people of India. Hinduism is believed to have been introduced by India's early Aryan conquerors, who appear to have considered the dog to be unclean and its flesh to have been unfit for normal food. Among the earliest of Hindu legends is that of Manu, a divine being, founder of the human race, who was saved from a great flood which destroyed all other created beings. He was the inventor of sacrificial rites, the author and first teacher of legal maxims. He taught that a Brahmana must never eat " food given by intoxicated, angry, or sick men, nor that in which hair or insects are found, nor that which has been touched intentionally with the foot ... nor that which has been pecked at by birds or touched by a dog,* nor the food given by a physician, a hunter, a cruel man, or one who eats the fragments of another's meal, $\uparrow$ by trainers of hunting dogs, publicans, a washerman, a dyer, or a pitiless man." I Manu declared, however, that " the flesh of an animal killed by dogs is pure." "The porcupine, the hedgehog, the iguana, the rhinoceros, the tortoise, and the

\footnotetext{
- "The Laws of Manu. Sacred Books of the East," edited by Max Müller, vol. iv, p. 208.

† Ibid., vol. iv, p. 212.

† Ibid., vol. v, p. I3 1 .
} 


\section{DOG-LORE AND SUPERSTITION}

hare they declared to be eatable; likewise those domestic animals that have teeth in one jaw only, excepting camels." If a Brahmana "has a strong desire for meat he may make an animal of clarified butter or one of flour (and eat that)." In spite of the prohibition of dogs' flesh, food obtained by begging was always pure, and "Vamadeva, who well knew right and wrong, did not sully himself when, tormented by hunger, he desired to eat the flesh of a dog in order to save his life." "Visvamitra, who well knew what is right or wrong, approached, when he was tormented by hunger, (to eat) the haunch of a dog, receiving it from the hands of a Kandala."

The dog was one of the five sacrificial animals of the Chinese, and similarly dogs were occasionally sacrificed by the Hindus. "All the gods are concerned in the horse-sacrifice; when he says 'I sprinkle thee for all the gods,' he makes all the gods take a concern in the horse-sacrifice. But his wicked enemy seeks to lay hold of him who performs the horse-sacrifice, and the horse is a thunderbolt ; having killed the four-eyed dog, he, with 'Undone is the man! Undone is the dog!'plunges it under the horse's feet." *

The whimsical solemnity with which Chinese officials have been apt to lay down high-sounding and heavily-worded rules and regulations upon the most trivial subjects for the guidance of those desirous of avoiding the stigma of want of culture, and for the glory of the letter of the law, is illustrated by a further quotation from the "Book of Rites" setting forth the procedure in presentation and acceptance of dogs: "When honouring by the gift of a dog, it is to be led with the left hand." The commentator gravely adds : "The reason for leading with the left hand is that the right may be ready to restrain the dog from biting." $t$ If acceptable, the re-

" "Sacred Books of the East," vol. xliv, p. 279. † "Book of Rites," vol. i. 


\section{DOGS OF CHINA AND JAPAN}

cipient's representative was first to take the leading-rope, and then to ask the dog's name.

As this procedure regulated the gift of house-dogs and hunting-dogs only, it is implied that gifts of edible dogs are not to be presented by hand, but must simply be sent to the kitchen, their points being judged, not by visual examination, but by the more searching test of the palate.

It may be mentioned, as an interesting trait in the Oriental character, that the early Chinese in their writings imagined themselves so much superior to foreigners that they alone could claim descent from human ancestors. They assigned canine origin to all neighbours except those of the South, to whom ophidian parentage was ascribed. Consequently, canine names were given to the peoples of the North, East, and West, and it was only in $185^{8}$ that Lord Elgin was able, by the cumbrous procedure of diplomacy, to obtain, as one of the stipulations of the Tientsin Treaty, "that henceforward the character ' I' (having both in writing and by its verbal usage the significance of canine ancestry) shall not be applied to the Government or Subjects of Great Britain." Similar privileges are not enjoyed by the wild tribes of Western China, and the result is that they suffer under such dog-names as T'ung, Yao, and Lolo to this day.

Kaempfer, who visited Japan in I69I on behalf of the Dutch East India Company, remarks : "Since the now reigning Emperor (Kinsen, I687) came to the throne, there are more dogs bred in Japan than, perhaps, in any one country whatever, and than there were before even in this Empire. They have their Masters, indeed, but lie about the streets and are very troublesome to passengers and travellers. Every street must by special command of the Emperor keep a certain number of these Animals and provide them with victuals. There are Huts built in every street, where they 


\section{DOG-LORE AND SUPERSTITION}

are taken care of when they fall sick. Those that die must be carried up to the tops of the mountains and hills, as the usual burying places, and very decently interred. Nobody may, under severe penalties, insult or abuse them, and to kill them is a capital crime whatever mischief they do. In this case notice of their misdemeanours must be given to their keepers, who are alone empowered to chastise and punish them. This extraordinary care for the preservation of the Dogkind is the effect of a superstitious fancy of the now reigning Emperor,* who was born in the sign of the Dog (the reader is desired to take notice, that the Dog is one of the twelve Celestial Signs of the Japanese, as shall be shown hereafter in Book II, Chap. 2), and hath for this reason so great an esteem for this Animal, as the Great Roman Emperor Augustus Casar is reported in Histories to have had for rams. The natives tell a pleasant tale on this head. A Japanese, as he was carrying up the dead carcase of a Dog to the top of a mountain, in order to its burial, grew impatient, grumbled and curs'd the Emperor's birthday and whimsical commands. His companion, sensible of the justice of his complaints, bid him hold his tongue and be quiet and, instead of swearing and cursing, return thanks to the Gods that the Emperor was not born in the Sign of the Horse, because in that case the load would have been much heavier." $†$

The beliefs of the Aryansans, the ancient Persians who disguised gods as dogs, caused them to punish even more severely any crimes against dogs. It was safer to kill a man than to serve bad food to a shepherd dog. The Zend Avesta allots two hundred stripes for throwing to the ground a part

* Thunberg does not entirely agree with Kaempfer. He says, "La veneration pour les chiens est bien antérieure au temps de Kaempfer, et subsiste encore aujourd'hui ; je ne puis l'attribuer qu'aux services rendus par ces animaux les ancêtres, à l'époque de leur établissement dans ces îles. Thunberg, "Japon," vol. ii, 1796.

† Kaempfer's " History of Japan," by J. G. Scheuzer, J. MacLehose, vol. i, p. 196. 


\section{DOGS OF CHINA AND JAPAN}

of a dog's carcase no bigger than two ribs, thirty stripes were the penalty for throwing down a bone as large as the top joint of a man's little finger.

Though the Chinese, unlike the Egyptians, have never worshipped the dog, and have seldom used it in sacrificial ceremony,* they have allowed it to enter into religious ceremonial, and it has secured no mean place among the legends of the superstitious.

In the Hatamen, one of the main streets of Peking, stands an Imperial Temple recently reduced to small dimensions. This temple is the oldest in the city. It is said to date from the T'ang Dynasty, and is dedicated to the god Erh Lang, the Chinese St. George, famous for his prowess in the extermination of dragons.' Erh Lang is the protector of dogs, and possesses a magic dragon-slaying sword. He is owner of the dog which howls in the sky, and which, like the Fenris Wolf, eats the sun. This dog is known to Europeans on account of

* J. F. Hewitt, Fourn. R. As. Soc., 189o, p. 441. "Another animal which was sacrificed in other countries, but not so far as I can discover in India, was the dog. The history of this sacrifice seems to throw most valuable light on ancient chronology and the course of religious evolution. The dog was certainly a sacred animal to the Northern Akkadians, as it is represented in their mythology by the four hounds of Bel-Merodach." (Sayce Hibbert Lectures, 1887, pp. 288, 289.) But it is as the animal sacred to the fire god Adar that it appears as a sacrificial victim in Asia Minor, Greece and Italy. Adar, or Uras, was at Nipur ' the god of glowing fire,' and was a most popular deity at Nineveh among the Northern Assyrians, but was not a favourite with the Southern or Semitic Babylonians (Ibid., pp. 152-54). This god became in Asia Minor the Tyrian Hercules called Melgarth, and there he was especially associated with dogs. Dogs were also sacred to the Athenian Hercules, as is shown by the name Cynosarges, or dog's yard, where his shrine was situated. According to FElian, sacred dogs accompanied the Sicilian god Adranus, who has been identified with Adar. But it is in the worship of Ares in Greece, and Mars in Rome, that we find the dog actually sacrificed. Dogs were sacrificed to Ares in Sparta, and the Latins offered a red dog to Mars at the Arvalia, to prevent the crops taking fire. The symbol of Ares was Sirius, the dog-star, and there thus appears every reason to connect him with the Akkadian Uras, the god of glowing fire. The development of this god into Hercules with the club, shows that the god of fire was originally the god of the firestick, who in the ancient triad took the place of the phallic father.

"Throughout the Rigveda and Brahmanas the dog and Agni are both regarded as the messenger of the gods." 


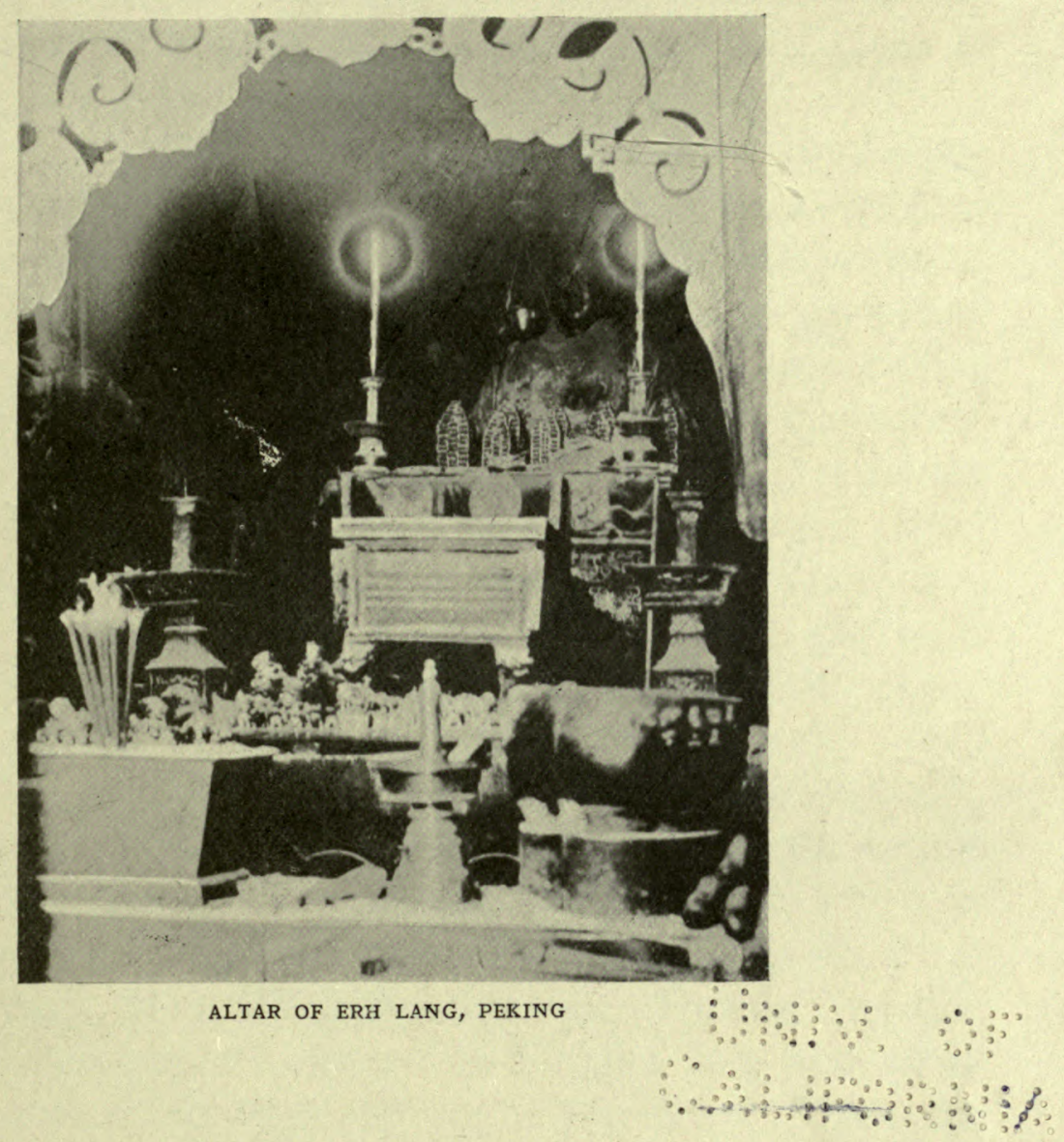





\section{DOG-LORE AND SUPERSTITION}

the noisy manner in which, up to recent years, when the sun or moon stood in danger of eclipse, the people attempted to dissuade him from his celestial meal.

The Chinese term for an eclipse is still the "eating up " of the sun or moon. The demonstrations which, up to the inauguration of modern reforms in China, took place at an eclipse were described by Gray:

"Five months prior to the eclipse the head of the Li-poo Board at Pekin, in obedience to the commands of the Emperor, forwards a despatch to the chief rulers of each province, and through him to the chief magistrate of each prefecture and each county, requesting them at the approaching eclipse to save the sun. At the time all the mandarins, attired in black robes, assemble at the official residence of the chief magistrate. When they have arranged themselves before an altar erected in the courtyard of the yamen, the chief magistrate burns incense on the altar and beats a drum three times. At this stage all the officials present fall down before the altar and perform the kow-tow. The ceremony on the part of the officials having been brought. to a close, a number of underlings continue, until the eclipse is over, to beat drums and tom-toms with the view of frightening and thereby preventing the Tien-Kow or heavenly dogs from devouring the sun. During this din, priests of the respective sects of Buddha and Tao stand before the altar and chant appropriate prayers. Upon the tops of all the dwelling-houses and shops of a Chinese city, men are also stationed who, by means of drums, tom-toms, and horns add to the general din. The same ceremonies take place during an eclipse of the moon. Formerly in other lands, as in China to-day, an eclipse of the sun or moon was beheld with terror. To rescue the moon from the spell of the enchanter, other nations, like the Chinese 


\section{DOGS OF CHINA AND JAPAN}

of the present day, had recourse to the blowing of horns and the beating of drums and brazen pots and pans. This ridiculous custom was evidently in full force in the day of Juvenal, who alludes to it in a description of a brawling woman-

- Forbear your drums and trumpets, if you please,

Her voice alone, the labouring moon can ease,." *

The importance attached by the ancients to prompt measures for countering this danger is shown by the fate meted out to two inaccurate astronomers of antiquity, as recorded in the Classics : "Now here are He and Ho. They have entirely subverted their virtue and are sunk and lost in wine. They have been the first to allow the regulations of heaven to get into disorder, putting far from them their proper business. On the first day of the last month of autumn the sun and moon did not meet harmoniously in Fang. The blind musicians beat their drums, the inferior officers and common people bustled and ran about. He and Ho, however, heard nothing and knew nothing. The statutes of the government say 'when they anticipate the time let them be put to death without mercy; when they are behind the time let them be put to death without mercy." "†

This mythical dog is quaintly described in a popular work on the Chinese minor deities. "The How Tien Ch'uan, or Heavenly Barking Dog (belonging to the deity Erh Lang), when sublimed from the earthly state, became a thin-bodied or coursing dog, having the size of an elephant, and the likeness of the strong and fierce owl which eats its parents. Its head is as brass and its neck as iron. Terrible in battle, its antagonist, however fierce and powerful, is quickly consumed, even unto the last of his bones." To this idea of the existence

* "China," J. H. Gray, vol. i, p. $267,1878$.

† Legge's Chinese Classics, "Shoo King," Part III, Book IV, chap. ii. 


\section{DOG-LORE AND SUPERSTITION}

of a celestial dog may be due the practice, said to be current in parts of China, of carrying in processions praying for rain in time of drought, a big dog housed in a palanquin and dressed like a man.*

It is probable that this celestial terror is identical in Chinese mythology with the heavenly dog which has the sinister reputation of trying to snatch children from their homes. In many temples there is an image of the god Ch'ang Hsien, and near him are his children. He is represented as shooting an arrow at a dog appearing in a cloud. $f$ Doolittle furnishes the following explanation for the worship of this deity by the women of China : "Some women are born on days which are represented by the chronological or horary character which means ' dog.' These women after marriage and before they give birth to a child, must procure a picture of the genius shooting the 'heavenly dog' and worship by the burning of incense and candles. The child then may be expected to live. .... In a celebrated temple located outside the East gate of the city of Foochow is an image of a large dog. It is currently reported that if bread, cakes, or biscuits made of wheat flour are placed in the mouth of this image and afterwards eaten by children, they will prevent or cure the colic." $\neq$

So great was the reputed powver of the magic sword and of the How Tien Ch'uan that, upon the best astrological advice, the Chinese Emperors of the recently defunct Ching Dynasty, being personifications of the dragon and also of the sun, forbore in their yearly visits to the Temple of the Sun, outside the East Gate of Peking, to take the nearest route, Lantern Street, which faces the Erh Lang Temple. This route would have brought the Son of Heaven upon his

\footnotetext{
* "Dog." "Encyclopædia of Religion and Ethics."

† Fung Chen Pang, "Anthology of the Deified."

$\ddagger$ "Social Life of the Chinese," by the Rev. Justus Doolittle.
} 


\section{DOGS OF CHINA AND JAPAN}

Dragon Throne into a dual menace-that of being smitten with the magic sword and eaten by the "Dog that Barks in the Heavens."

This Chinese mythical dog may be akin to the Aryan hedgedog, having a long and thin muzzle, the prickles on whose back were compared to the rays of the sun piercing the veil of darkness. "Whosoever, O Zarathustra! shall kill the dog with the prickly back, with the long and thin muzzle, the hedge-dog, which evil-speaking people call the Duzaka, kills his own soul for nine generations, nor shall he find a way over the Kinvad bridge unless he has, while alive, atoned for his sin by offering up a sacrifice to Sraosha." *

The idea of the heavenly dog appears to have reached the Chinese and the Hindus from a common source. From the fifth Brahmana we read : "(I) He observes the fast thinking 'to-day is the day of new moon' ; and then that moon is seen in the West. But, indeed, he (the moon) is that heavenly dog : he watches the sacrificer's cattle (to seize them) and that would not be good for the cattle in the case of the owner who did not make amends . . . and through fear of that 'downcoming moon,' as they think him to be, (2) they steal away into the shade. And, therefore, indeed, people call that burning pain 'svalukita ' (dog's clutch)." (I0) " A bow with three arrows he gives as dakshina ; for with the bow a dog is driven away: he thus drives away that dog (the moon) when he gives a bow with three arrows as dakshina." $\dagger$ The substance of the Brahmana legend is that certain demons piled up a fire-altar in order to ascend by it to heaven. Indra joined them, adding a brick of his own. When they had climbed to heaven Indra pulled out his brick and the demons fell. They became spiders, all but two, who flew up and

* "Sacred Books of the East," Zend Avesta, vol. iv, p. I52.

† "Sacred Books of the East," F. Max Müller, vol. xliv, p. ro 


\section{DOG-LORE AND SUPERSTITION}

became Syama and Sabala, the two heavenly dogs, otherwise known as the two four-eyed dogs of Yama, stated by Bloomfield to be the sun and moon.*

Similarly according to the Hindu belief, more ancient than Buddhism, the dog is placed on the same plane as man. "The wise look upon a Brahmana possessed of learning and humility, on a cow, an elephant, a dog and a Svapaka, as alike ". $\dagger$ Similarly, as there was no essential difference between man and beast, the beast must answer for its guilt. The mad dog or the dog which bit without barking, which wounded a sheep or man, paid for it as for wilful murder.f

Erh Lang in Peking is considered to be the protector of the canine race. To this day, on the first and fifteenth days of the month, native owners of dogs may be seen worshipping at the altar of the god. If their dogs are in danger of death they bring miniatures in clay and lay them on his altar, so that the god may, through the presence of a substitute, suffer the owner to keep his pet yet a little longer. It is possible that in this may be found a survival of the old idea that not only a curse but also a blessing pronounced upon a dummy counterfeit has effect upon the original.

Kaempfer refers to a Japanese counterpart to the dogprotecting deity, when referring to a visit to Fusimi, a suburb of Miaco, on the first of the month: "The temples which we had on our right, as we went up, being built in the ascent of the neighbouring hills, were illuminated with many lamps, and the priests, beating some bells with iron hammers, made such a noise as could be heard at a considerable distance. I took notice of a large white Dog, perhaps made of plaster, which stood upon an altar on our left, in a neatly adorned

* "Sacred Books of the East," vol. xlii, p. 500.

† Ibid., vol. viii, p. 65 .

$\ddagger$ Ibid., vol. iv, p. 159 . 


\section{DOGS OF CHINA AND JAPAN}

chappel, or small temple, which was consecrated to the Patron of the Dogs." *

In crediting the dog with some sort of a soul, Buddhism permits to the dog a closer relationship with man than does Christianity, which in the matter of salvation gives to the canine race not even the proverbial "dog's chance," and, indeed, claiming to himself a sole exclusive heaven, allows no closer association than did St. Bernard of Clairvaux when, preaching in the twelfth century, he likened the love of angels to man as being similar to that of a man's friendship to his dog, on the principle of the proverb, "Love me, love my dog," at the same time bringing into comparison the love of Deity to man and the love of man to his dog. $\uparrow$ Buddhists, indeed, recognize no essential difference, on spiritual grounds, between dog and man. Their faith is like that of the Indian who

\section{asks no angel's wings, no seraph's fire : \\ But thinks, admitted to that equal sky, \\ His faithful dog shall bear him company..}

In the Buddhist cycle the spirit of man commonly passes into the form of a dog. While mediaval Christianity represented dogs, indicating fidelity during earthly life, and lions, for valour, at the feet of their owners in many old brasses and stone effigies in churches, the Buddhist placed numerous representations of the dog in clay and pottery in early Chinese tombs, with a view to the retention of their services in the life to come. Christian lore gives earthly glory to the dog of St. Roch, a familiar beastie in French churches, honoured for the succouring of his master smitten with plague. The good Buddhist, to demonstrate that dog and man are merely units in the cycle of transmigration, will quote the conversion

* "The History of Japan," Kaempfer, Maclehose, vol. iii, p. I6.

† "Angeli amant nos, quia nos Christus amavit. Dicitur certe vulgari proverbio; qui me amat, amat et canem meum."

$\ddagger$ "The Indian and his Dog," Alex. Pope.

$3^{8}$ 


\section{DOG-LORE AND SUPERSTITION}

of the owner of a white dog recorded in the Scriptures. "At Stravasti, Buddha entered into the house of one Tu-T'i, who was absent from home. Upon the divan a white dog was eating from a bowl. At sight of Buddha it leapt to the ground and barked at the Holy One. Buddha said: 'Miser, how deep is thy degradation!' The dog betook itself to a corner in dejection. When Tu-T'i returned and saw his dog so sad he asked the cause of its misery. The servants replied, 'Buddha has done this.' Tu-T'i was angered and asked Buddha for an explanation. Buddha said: 'I did but tell him the truth. This animal is thy dead father. Born a dog, as punishment for his avarice, he still guards his riches. Order him to reveal the treasure which he has hidden, even from thee, his son.' Tu-T'i returned to his home and said to the dog, 'As thou hast been my father in thy previous incarnation, all of that which was yours is now mine by right. Show me thy hidden treasure.' The dog crept beneath the divan and began scratching the earth. There Tu-T'i dug and discovered great treasure. Forthwith he was converted to Buddha." *

The lamas of Thibet suggest that the miserable pariahdogs of their country are the re-incarnation of priests who have been faithless to their vows. The same idea may underly the inclusion of a dog, white for ill-luck and mourning, in the scapegoat party which is recorded by Nain Singh as being annually expelled from Lhasa. "On the 29th day of the first month a man is selected who is called the Logon gyalpo (or carrier of one year's ill-luck), who becomes a sort of scapegoat for the sins of the people. For a week he perambulates Lhasa as a sort of clown, with his face painted half black and half white, and is permitted extraordinary license. He shakes a black yak's tail over the heads of the people, thus transferring

" L. Wieger, " Bouddhisme," vol, xi, p. rog. 


\section{DOGS OF CHINA AND JAPAN}

from them to himself the full measure of their ill-luck. Then he receives certain presents from the government-a white horse, a white dog, a white bird, with other smaller gifts of provisions and offerings from the people. Finally, he is hunted out of the town amidst the yells of the mob, towards the Samye monastery, where he may (if he survives his treatment at the hands of the people) be accommodated in the Lhakang, or dead house." $*$

Certain animals, such as foxes and dogs, are considered by Buddhists to be able to appear in human shape and to play the part of the were-wolf, or incubus, of mediæval legend. Consequently, it is not surprising to find in Chinese and Japanese, just as in European legend, that " the devil appears in the horrible shape of some black dog or other frightful hairy fraybuggs," and that the black dog which sits upon the back of the sulky, Faust's black poodle, the Gabriel Hounds which hunt along the tree-tops on dark and stormy nights, and Sir Walter Scott's Mauthe dog-a " large black spaniel with curled shaggy hair "- have analogies in Chinese superstition, often as intergrowths with the old Chinese empirical system of natural science called Feng Shui, used by Chinese astrologers and diviner fortune-tellers to the present time. They classify all beasts of astrological importance as subject to the yang (male) influence of the sun-this category includes the dog-or the ying (female) influence of the moon-comprising the cat. The Chinese do not appear, however, to use the traditional cat and dog antipathy in hate-charms as in Palestine, where the putting of hatred between the members of a family is attained by the giving of one half of the egg of a black hen to a dog and the other to a cat, with the recitation of appropriate charm-words; nor have they the old legend of Palestine, which states that once upon a time when the world * "Tibet the Mysterious," by Sir Thomas Holdich, p. 3 ro. 


\section{DOG-LORE AND SUPERSTITION}

was young, to each and to every kind of animal a duty was assigned. The dog and cat were relieved of menial duty, because of the faithfulness of the one and the cleanliness of the other, and a written document was given them in attestation thereof, and the dog took charge of it. He buried it where he kept his stock of old bones, but this privilege of exemption so roused the envy of the horse, ass, and ox, that they bribed the rat to burrow underground and destroy the charter. Since the loss of this document the dog has been liable, on account of his carelessness, to be tied or chained up by his master, and the cat has never forgiven him." *

It must be remembered that in matters of superstition many Chinese still roam in the dark mazes through which the mediæval astrologers, soothsayers, and diviners led our bewildered ancestors. A dog which is completely black is believed to be able to frighten away spirits, and to this day a Chinese witch-doctor who wishes to expel a particularly malignant devil will ruthlessly slay a black dog in which not one white hair is found, gather its innocent blood into a bowl, and sprinkle this gore before the spirit with a wooden sword, accompanying the ceremonial with mumbled prayers, charms, and spells to support the sacrifice and exorcise the fiend to eternal perdition. Not in China only has the dog been made to suffer for utilitarian mankind. "To tame a lion, they used to beat a little dogge before him." "What, man!" says Shakespeare, "there are ways to recover the general again: a punishment more in policy than in malice; even so as one would beat his offenceless dog to affright an imperious lion." +

* Hanawer, Palest., "Animal Folklore," Palest. Exp. Fund, 1904, p. 265,

f This may throw light upon a curious passage dealing with the use of huntingtigers in Marco Polo's narrative, "The Grand Khan has many leopards and lynxes kept for the purpose of chasing deer, and also many lions, which are larger than the Babylonian lions, have good skins, and of a handsome colour, being streaked length- 


\section{DOGS OF CHINA AND JAPAN}

Archdeacon Gray* describes the Taoist ceremony performed for the expulsion of spirits inducing suicide. "After the priest has made a great many signs and performed the kow-tow, he receives from the inmates a small black dog, together with a chopper and a block; and when he has severed its tail from its body with a sharp blow, the wretched animal, with a cord round its neck, is led, or rather dragged, piteously howling, by the head of the family into every nook and corner of the house. It is then taken to the front door and kicked into the open street. The bleeding and yelping cur is supposed to frighten away the evil spirits, and to pursue them in their flight through the streets. By way of purifying the house, the priest then walks through it with a brass pan containing a burning mixture made of sulphur, saltpetre, and other inflammable ingredients." This custom may be compared for barbarity with the old German and Scandinavian custom of hanging dogs with criminals as a symbolical mark of disgrace and as an aggravation of the punishment. $\dagger$

The following is quoted as an instance of the fantastic shapes into which the professors of Feng Shui are willing to distort their crude theories in the name of science :

"The influences $\ddagger$ of the Five Elements $\S$ attack and impair each other, and bloodthirsty animals conquer and overpower each other; how are these phenomena to be explained? The

ways, with white, black, and red stripes. They are active in seizing boars, wild oxen and asses, bears, stags, roebucks, and other beasts that are objects of the sport. It is an admirable sight, when the lion is let loose, in pursuit of the animal, to observe the savage eagerness and speed in which he overtakes it. His Majesty has them conveyed for this purpose in cages placed upon cars; and along with them is confined a little dog, with which they become familiarized." Marsden "Travels of Marco Polo," 1818 , p. 338 .

"Notes and Queries, and Series, xii., p. 5 ro.

† "China," J. H. Gray, vol, i., p. 336, Macmillan, 1878.

I Groot, "The Religious Systems of China," vol. iii., p. 988, from " Discussions and Criticism from the Chinese 'Lun Heng ' of the Han Dynasty," chap. iii.

$\S$ Wood, wind, fire, water, and earth. 


\section{DOG-LORE AND SUPERSTITION}

answer is : The branch Yin corresponds to the element wood, whose animal is tiger ; Hsü appertains to earth, whose animal is the dog; Ch'en and Wei likewise appertain to earth, and their animals are the cow and goat. Now as wood overpowers earth, it follows that the tiger subdues dogs, cows, and goats. Hai appertains to water, whose animal is the pig. Sze corresponds to fire, whose animal is the Serpent. Hence, since water conquers fire, pigs can devour snakes. Tsze is identical with water, whose animal is the rat. Wu appertains to fire, whose animal is the horse. Since fire is destroyed by water, should a horse devour a rat it will fail to relieve itself and die of a swollen belly." 


\section{CHAPTER III}

\section{DOG-BREEDING}

1 $\mathrm{S}$ was natural in an agricultural people, dog-breeding found early encouragement among the Chinese, and no doubt the three heads, house, hunting and edible, into which the "Book of Rites" classified the canine race, owned several subdivisions, especially as regards the sporting dogs. The early Chinese emperors went to excess in their love of the chase, and the numerous embassies exchanged with foreign rulers gave them every opportunity of introducing at early periods rare dogs from neighbouring states, including perhaps even such breeds as the greyhound, the bulldog, the terrier and the slow-hound, which existed in England at the time of the Roman occupation, and were of such quality as to add zest to the gladiatorial sports and gave to England not a little of its fame among the Romans, a fame destined to be increased by descendants of those breeds.

During the Tudor and Stuart periods the renown of British dogs, especially mastiffs, was such that they were used as political presents to many European countries, as well as to the Near and Far East. In I5I7 King Henry VIII thanked the Marquis of Mantua for the horses which were being got ready for him, and promised to recompense the Marquis "with English horses and dogs." Nine years later Henry sent to Francis of France " eight very handsome sporting dogs." In 1522 the Duke of Urbino's envoy at Henry's Court wrote that he had not forgotten the "little dog" 


\section{DOG-BREEDING}

(cagnolo), and would do his best to obtain one. In $\mathrm{I} 54^{\circ}$ Lady Lisle wrote to Madame du Bours in reply to a request for poodles for the crossbow or hackbut, "I will send to England for poodles (barbets), for I can get none in this town except one which I send for your son. He is very good at retrieving the head or bolt of a crossbow, both in water and on land, and will fetch a tennis ball or a glove put on the end of a stick, and other tricks." In 1546 Henry VIII sent to Mary of Hungary "greyhounds and running dogs," and in the same year he made the French queen " the gladdest woman in the world " by a present of "hobbies, greyhounds, hounds and great dogs." In this year, too, Anne of Cleves, who is credited by Lady Lytton with possible introduction of the liver-and-white toy spaniel into England, sent two brace of English greyhounds to her brother, the Duke of Cleves.* In I559 the envoy of the Duke of Mantua at Queen Elizabeth's Court wrote: "The Queen did not act thus with the French Lords, to whom she gave gifts more than splendid, viz. To Mons. Montmorency : ... divers dogs-mastiffs, great and small, hounds (scurieri) and setters-a quantity of every sort." These were no doubt reared in the royal kennels in the Isle of Dogs, near the palace of Greenwich. The breeding of fine mastiffs was probably due to a state of public opinion which breathed the sentiment:

\footnotetext{
Let dogs delight to bark and bite,

For God hath made them so.

Let bears and lions growl and fight,

For 'tis their nature too. $\dagger$
}

and considered dog-fighting, together with bull and bearbaiting, to be little less than national pastimes.f Bull-

* "Calendar of State Papers, Henry VIII."

t Isaac Watts.

f "The fee of the Master of the Cocks [under James I] exceeded the united salaries of two Secretaries of State."

"The Master of the Buckhounds, who is also one of the Ministry, ranks next to the Master of the Horse." "Murray's Dictionary," vol. vi, p. 213. 


\section{DOGS OF CHINA AND JAPAN}

baiting, in which sport a tethered bull with blunted or padded horns was pitted against dogs which he sometimes tossed thirty or forty feet high, was a pastime almost national in importance for centuries. Pepys remarks in 1666 that he "saw some good sport of the bull's tossing of the dogs, one into the very boxes." *

In 1557 the envoy of the Duke of Mantua, after remarking that in the Tower of London " there is a seraglio in which from grandeur they keep lions and tigers and cat-lions," goes on to say that " there is the bear garden in Southwark, on the banks of the Thames, where they keep big dogs to rear for breeding, and to exercise them there are bears, wolves and bulls; so for such purposes they become very good dogs (buonissimi cani)." In I608 to I6ro James I sent dogs as presents to the princes of Anhalt and Brunswick, also to the Ambassador of Brandenburg. In $\mathrm{I}^{6} \mathrm{I}_{4}$ the Venetian Ambassador in Spain reported that there had recently arrived from James of England a present to Philip of Spain including "palfreys, dogs for hunting lions, arquebuses and sables and crossbows." In I6I4 General Saris was employed by the East India Company in opening up trade with Japan, and was received in a very friendly manner by certain of the Japanese feudal lords. As a result of his observations he wrote to the "Captain Generall of the English appoynted to Japan" that he should "make some small present to the daimio of Hirado and Iki, and to his son. The fittest things for the owld Kinge wilbe a vest of delicatt fine blacke cloth

* These barbarities cannot compare with those recorded by travellers in mediæval India. "Sometimes this manner of execution [tearing asunder by elephants] is used by the Kinge [of Agra] and great men, Alsoe throwne to doggs bredd for that purpose. Other tymes to wilde beasts, Yea, Sometymes appoyntinge certain men to teare the offender with their teeth, of which Cuttwall Chaun was said to bee one, Commaunded thereto by Jehangueere [Jahangir] because hee was a bigg fellowe and had a good sett of teeth." "The Travels of Peter Mundy," Hakluyt Society, ser. II, vol. xxv, p. 232.

46 


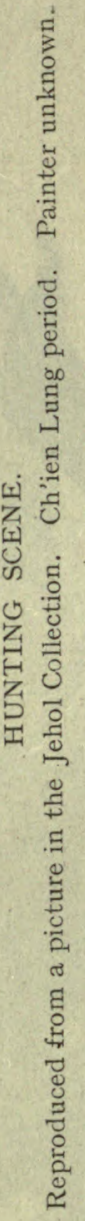





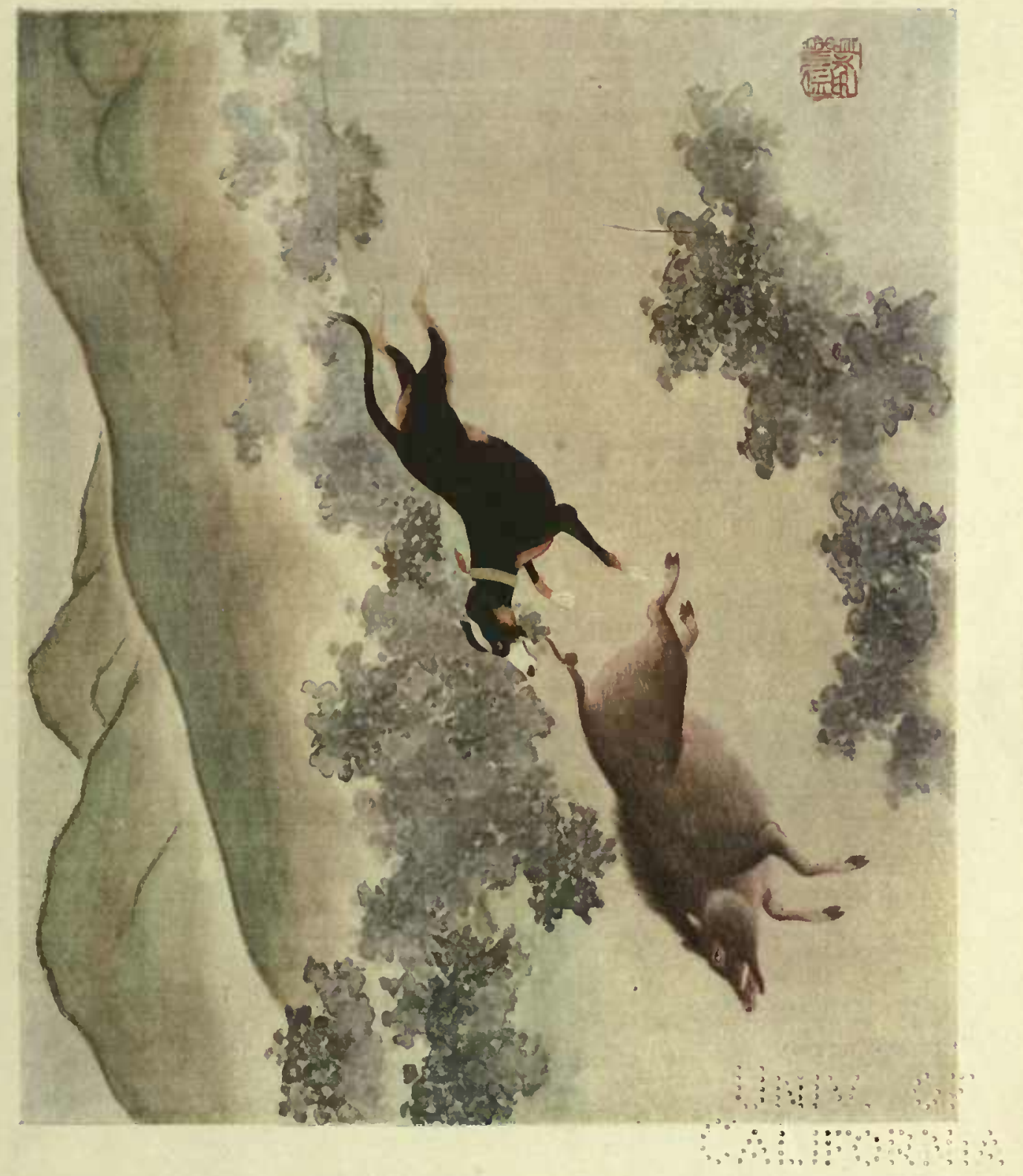


$\because \because \quad \quad \because \vdots \vdots \vdots \vdots \vdots \vdots \vdots 0)$

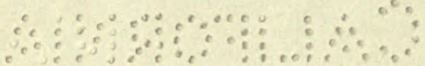




\section{DOG-BREEDING}

lyned through with black coniskinns made sweete; to his sonne a fair headpeec and gorgett, a box of all such thinges as ar belonging to a faulconer, quayle calls, a mastife, a watter spaniell and a faire grayhound." * In $16 \times 8$ Queen Anne sent six horses and thirty couple of hounds to the King of France. In 1623 James presented Louis with another pack, and in 1627 Louis XIII intimated to his sister, Henrietta Maria Queen of England, that he would expect four hunting dogs of her. $\dagger$

In ancient China all treasures, including pearls, jade, or rare animals, were considered to be Imperial property, and their producers were bound to offer them in the first instance to the Emperor, who was accustomed to give generous reward, by official promotion or otherwise, in return. The breeding of dogs possessed another incentive to the early Chinese, not known to the inhabitants of the West, for in China considerable importance was attached, on superstitious grounds, to the colour and markings bred in dogs. Fortunate markings might bring honour to a family and to its ancestors. This superstitious belief was encouraged, if not originated, by geomancy or "Feng Shui." Similarly, the reputed occurrence of a Chilin or phønix was the most auspicious of events, and the donor of such rare and precious natural products to the Chinese Emperors was always richly rewarded. The appearance of certain markings, such as a black or yellow coat in conjunction with a white head, or two white forelegs in a black dog, was hailed as sure presage of official appointment. Similar superstitions survive to this day in quaint couplets and proverbs which even now influence the breeding of dogs. In pigeon-breeding the Chinese have progressed a step farther than with their dogs. They have

* "Voyage of Capt. J. Saris to Japan," Hakluyt Soc., App. A., p. 209.

$\dagger$ "Calendar of State Papers, Venice." 


\section{DOGS OF CHINA AND JAPAN}

evolved many species which have constant colour characteristics, each with its special highly imaginative Chinese name, and each favoured by particular fanciers.

Hard times and the overthrow of the Manchus have, however, done much to extinguish Chinese interest in breeding dogs. Had the Peking breed remained as fashionable as it was in the early days of the nineteenth century, it seems probable that the Chinese would have succeeded in perpetuating several varieties, each with characteristic markings, instead of the one race now produced in Europe and America, which is an amalgamation of the characteristics of several, bred irrespective of markings. To the Chinese, saturated with superstition, folk-lore and literary myths, every colour has a value, and every marking serves to crystallize some imaginative thought which can convey little to the foreigner ignorant of Chinese underlying thought.

"Should a man breed a white dog with tiger markings," remarks one of the old geomantic books, "he shall shortly become an official entrusted with 10,000 piculs (roughly 600 tons) of rice, from the Government." *

The ancient "Book of the Five Elements," rather more exacting in its requirements, proves that dogs of various colours existed in early times in China, as in Assyria : $\uparrow$

"Should a man breed :

"A black dog with white ears, he shall become rich and noble.

"A white dog with a yellow head, his family will become prosperous.

"A yellow dog with white tail, his family shall have officials in it in every generation.

* "Ke Chih Ching Yuan" (Clear spring of ancient knowledge).

$\uparrow$ The Assyrians and Babylonians "were acquainted with dogs of various colours, for they derived omens from piebald dogs, yellow dogs, black dogs, white dogs and the rest." "Mesopotamian Archæology," by Percy S. P. Handcock, Macmillan, I 912 p. I9. 


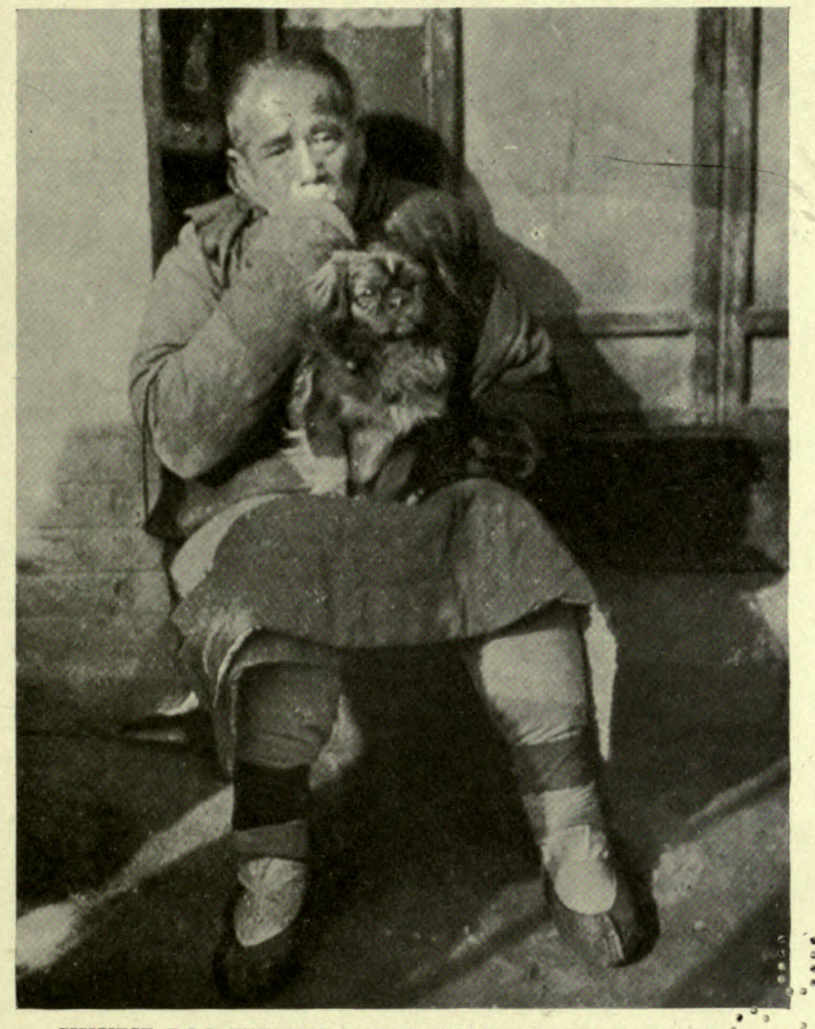

CHINESE DOG-BREEDER, LUNG FU SSU MARKET, PEKINC







\section{DOG-BREEDING}

"A black dog with white fore-legs, many male children will be born to the family.

"A yellow dog with white fore-legs, he will have good luck. "The breeding of a white dog with a black head is lucky, and will bring a man riches.

"A white dog with a black tail will cause the family through all generations to ride in chariots." *

With these old superstitious beliefs may be compared the ancient Parsee rite for expulsion of the corpse-drug from the dead by means of a dog having two spots above the eyes or of a white dog having yellow ears. "As soon as this dog has looked at the dead," remarks the ritual, "the Drug flees back to hell in the shape of a fly. $\dagger$

Numerous historians refer to the care bestowed by the Emperors of the Tang and Sung Dynasties upon their dogs. These Emperors, unlike the English kings, who when resident at Greenwich kept their sporting kennels at the Isle of Dogs, appear to have bred their dogs in the palace, and even in the Imperial ancestral temple. Under the Emperor Wan $\mathbf{L i}$ $(1563-1620)$ this was prohibited, and one of the eunuchs, guilty of keeping a small dog in this temple, escaped severe punishment only on payment of a substantial "squeeze."

In Europe remarkable freedom was allowed to dog-owners by the mediæval Church. The office of "dog-whipper," whose holder's duty was to keep the congregation's dogs in order while in church during services, was held in numerous churches in England, and in some persisted beyond the middle of the nineteenth century. On the Continent, too, it was customary to allow dogs to enter sacred buildings with their masters. "At Avignon the dogs made love or war, and barked in the churches at pleasure." $\ddagger$

* In ancient China only members of families in which there were officials were allowed to ride in carts.

† " Sacred Books of the East," Zend Avesta, vol. iv, p. Ixoxvii.

\pm Notes and Queries, p. 343, October 1897 . 


\section{DOGS OF CHINA AND JAPAN}

The Chinese Emperors used their expeditions into the hunting-parks for the training of their armies and for demonstrating their power to the tribes of Mongolia. Each of the soldiers became a huntsman or beater for the occasion. Similarly, though it does not appear likely that all of the vast number of dogs used possessed powers of scent, any more than do the great majority of dogs to be found in the villages of the hunting-parks at the present time, every available dog was pressed into service.

Friar Odoric, who spent three years between 1322 and 1328 in Peking, "took the opportunity to make diligent inquiry from Christians, Saracens and all kinds of idolaters," who all told him with one voice that "the king's players alone amount to XIII tumans (10,000 men); that, of those others who keep the dogs and wild beasts and fowls, there be $\mathrm{XV}$ tumans; of leeches to take charge of the royal Person there be 400 idolaters, eight Christians and one Saracen." *

Marco Polo further speaks of two barons as "having charge of the hounds, fleet and slow, and of the mastiffs," $\dagger$ and states that each of them maintained a body of ro,000 men dressed alike, the one lot in livery of red, and the other in blue, to accompany the Great Khan to the chase : "Of the 20,000 men there were 2000 , each of whom was in charge of one or more dogs, and when the Prince goes a-hunting, one of these barons with his ro,000 men and something like 5000 dogs $\ddagger$ goes towards the right, whilst the other goes towards the left with his party in like manner. The whole line extends for a full day's journey, and no animal can escape them. Truly it is a glorious sight to see the working of the dogs and the huntsmen on such an occasion, and as

" "Cathay and the Way Thither," Yule.

$\dagger$ "Marco Polo," Marsden's edition, translated from the Latin.

f "Marco Polo," Marsden's edition reads " the dogs of different descriptions ... are not fewer than five thousand." 


\section{DOG-BREEDING}

the Lord rides a-fowling across the plains you will see this big hunt come tearing up, one pack after a bird, and another pack with a stag or some other beast, as it may hap, and running the game down, now on this side and now on that, so that it is really a most delightful sport and spectacle." *

The Ming Emperors devoted too much of their time to the breeding of cats. One of the eunuchs registered a protest against the practice, complaining that the cats-were so noisy that the Imperial children were caused to sicken and die. He remarks that the cats should have been confined to special quarters, and suggests that the Emperors encouraged their sons to interest themselves in the breeding of cats and pigeons because, surrounded by eunuchs and women, they might fail to realize the importance of rearing children.

Critics of Chinese success in dog-breeding may point to the absence of high development of powers of scent in Chinese dogs. It must be remembered, however, that the British pointer is a dog of modern times, produced since r650, derived from a foreign race, the development of whose powers has resulted from careful selection, and whose very existence is due to the fowling-piece. As evidenced by mention of sporting dogs in the "Book of Rites," written in the seventh century B.C., the Chinese vie with the Romans for the honour of being the first to record use of the dog in the chase. "The first hint of the employment of the dog in the pursuit of other animals is given by Oppian in his "Cynegetica." He attributes it to Pollux about 200 years after promulgation of the Levitical law." $\dagger$

Breeds have become stable in England only in recent years with the fixing of standards and the use of shows, started in London in $1836 \ddagger$ and almost accidentally at Newcastle in

" "Marco Polo," Yule.

† "Toy Dogs and their Ancestors," p. 100.

† Encyclopedia Britannica, " The Dog." 


\section{DOGS OF CHINA AND JAPAN}

I859, which have become possible on account of modern improvements in transport. That the Chinese should have been able to secure high specialization of breed in pigeons, goldfish, lap-dogs and cats is a strong testimony to their realization of the importance of selection at a time when skill in the same art was less developed in Europe.

Development of the breeds of Pekingese dogs probably owes more to the efforts of the palace eunuchs than to those of their Imperial masters. An Emperor such as Tao Kuang and his consort would, by their enthusiasm for breeding pigeons and dogs, set the fashion, and the eunuchs, more than a thousand in number, living in the "Forty-eight Places " of the palace, would vie with one another in endeavouring to breed to the standards set up, with a view to securing either favour from their superiors by presentation of good specimens, or profit from officials similarly inclined, by sale.

Shows, breeding to closely defined points, and the keeping of careful pedigrees, have never existed in China. The only recognized standards to which dogs have been bred are those contained in the dog-books of each Imperial master, as painted by the Court painters. Very few of these books have been allowed to leave the Imperial and princes' palaces. Each Emperor caused illustrations of his favourite dogs to be made by the Court painters in books or on scrolls, and in this way was set the current fashion in breeding. The highest compliment a Chinese breeder in Peking can give is to judge that a specimen is good enough to "go into the book," that is to say, into an Imperial dog-book. Such of these books as have been obtained portray dogs closely resembling the "Pekingese" type, as also the "Shih-tzu" dog and the "Pug."

The old belief recorded of Jacob when he " took him rods 


\section{DOG-BREEDING}

of green poplar, and of the hazel and chestnut tree, and pilled white strakes in them, and made the white appear which was still in the rods " and used them in breeding, still persists both in Tibet and China. The Tibetan Lamas state that images of the Tibetan lion are used in breeding the lion-dog. The eunuchs of the Peking palace use pictures of good dogs and dog-scrolls with the same intent.

The late Empress Dowager bred her pet dogs chiefly with a view to developing symmetrical markings. There appears little doubt that both she and her predecessors strongly encouraged the lion-dog idea on account of the implied comparison of themselves with Buddha. The "Old Buddha" herself was, according to Miss Carl, strongly against the development of any abnormality or artificial modification of shape. This was not the view of the palace eunuchs, however. They endeavoured to modify development of body in many ways. One method was to allow the dog to take little exercise from the third month to maturity, with the idea of lessening the appetite, and thus retarding growth. Some of them were accustomed, even in recent years, to hold the growing specimen in the hand for days at a time, inducing, by gentle pressure of the fingers, a slight exaggeration of width between the shoulders. Another artifice was the feeding of the puppy with sugar, but it is stated that this was found to induce thirst, with the result that there was a tendency for the nose to lengthen on account of over-drinking, especially during the third month. During this period nose-development is said to be greatest, while the development of the legs is believed to be most intense during the fourth month. Consequently, from weaning, about the fortieth day to the ninetieth, strong soup only and no water is given to the puppies. One method alleged to have been in use for arresting development was, as in the 


\section{DOGS OF CHINA AND JAPAN}

case of foot-binding, particularly cruel. It is said that the puppies, when small, were enveloped in wire cages closely fitting the body and not removed until maturity was reached.

The methods of securing shortness of nose were more various than effective. They appear to have been in vogue only among the more ignorant breeders, and the better informed are persuaded that the only reliable means of securing good points is by careful selection in breeding, a matter which is becoming increasingly difficult in China through dearth of good specimens.

It is a common practice to break the cartilage of the nose with the thumb-nail or a chopstick while the puppy is from three to seven days old, but this can be detected on account of the exaggerated snoring of the mutilated dog in after-life. Dr. J. E. Gray, in describing the skull of a Chinese "Pugnosed Spaniel " in 1867 , remarked, "The nose of the Chinese or Japanese Pug is said by some to be artificially produced by force suddenly or continuously applied, but this is certainly not the case in the skull that is in the British Museum; for the bones of the upper jaw and the nose are quite regular and similar on the two sides, showing no forced distortion of any kind, such as is to be observed in the skulls of some Bull-dogs." *

Other breeders feed their puppies from a flat plate, or encourage them from the age of three months upwards to bite pigskin stretched on a board. Others will massage the nose daily, with the object of restraining growth of the obstinate organ, which, only too often in Peking, appears to be but little stunted by this persistent snubbing.

Dogs are largely bred in Mongolia for their skins. $f$ " There

" "On the Skull of the Chinese Pug-nosed Spaniel or Lap-dog," by Dr. J. E. Gray, F.R.S., Proc. Zool. Soc., 1867, p. 40.

† Alexander Hosie, "Manchuria," p. 205.

54 


\section{DOG-BREEDING}

are thousands of small dog-farms scattered over the northern districts of Manchuria and Mongolia, where from ten to hundreds of animals are reared yearly. When a girl is married she receives perhaps six dogs as her dowry, and it can easily be understood that this comparatively small beginning may be the foundation of a large fortune, seeing that reproduction of ten per annum would in a few years give an enormous total. A dog matures in from six to eight months, and the coat is at its best during the winter, so that the animal must be destroyed before the thaw sets in. It is doubtful whether the dogs' skins in any other part of the world are to be compared with those that come from Manchuria and Mongolia, either in size, length of hair, or quality." Sir Alexander Hosie remarks that the flesh of the dog is no doubt used for human food, and that its market value enters largely into the farm's profit and loss account.

"The animals are killed, not with the knife, which might injure the fur, but by strangulation. The skins dried and frozen find a market in Mukden and other places, where they are cured before the thaw affects them, and made into mats and robes."

Many of these skins are exceptionally large and fine, closely resembling those of the wolf and fox. Large numbers find their way to the European markets. 


\section{CHAPTER IV \\ SPORTING AND GUARD DOGS}

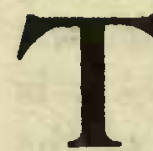

HIS heading is intended to include all breeds which are not toy-dogs. No breed can be said to exist in the East, as in Europe, for the special use of the amateur sportsman. Game is captured for the sake of food, and the element of sport, though attractive to the Chinese and Japanese hunter, is a minor incentive. Consequently, the term "sporting" is here applied to all dogs used in the capture of game, and includes the chow, the greyhound, and the wolf-hound. It may be contended that this classification is no great improvement on that of the "Book of Rites." As a matter of fact, no such classification can be perfect, for dogs closely allied to the type which has become fixed in England under the name of "chow" are used in China for the hunting of deer, the shooting of pheasants, as guard dogs, for the production of furs, for edible purposes, and as sledge dogs. Numerically, this race is probably the most important in the world. Extreme poverty of the people, and increasing difficulty of maintenance, has weakened this most democratic of all dog races, and caused it to deteriorate, but throughout China there is a distinct resemblance to the chow in the miscellaneous unclassified local breeds.

Laufer figures nine relief-bands on vases of the Han dynasty, connected with hunting scenes, the representation of which had become conventional at this period. The quarry is in several cases the wild boar, "well characterized by its short, 56 


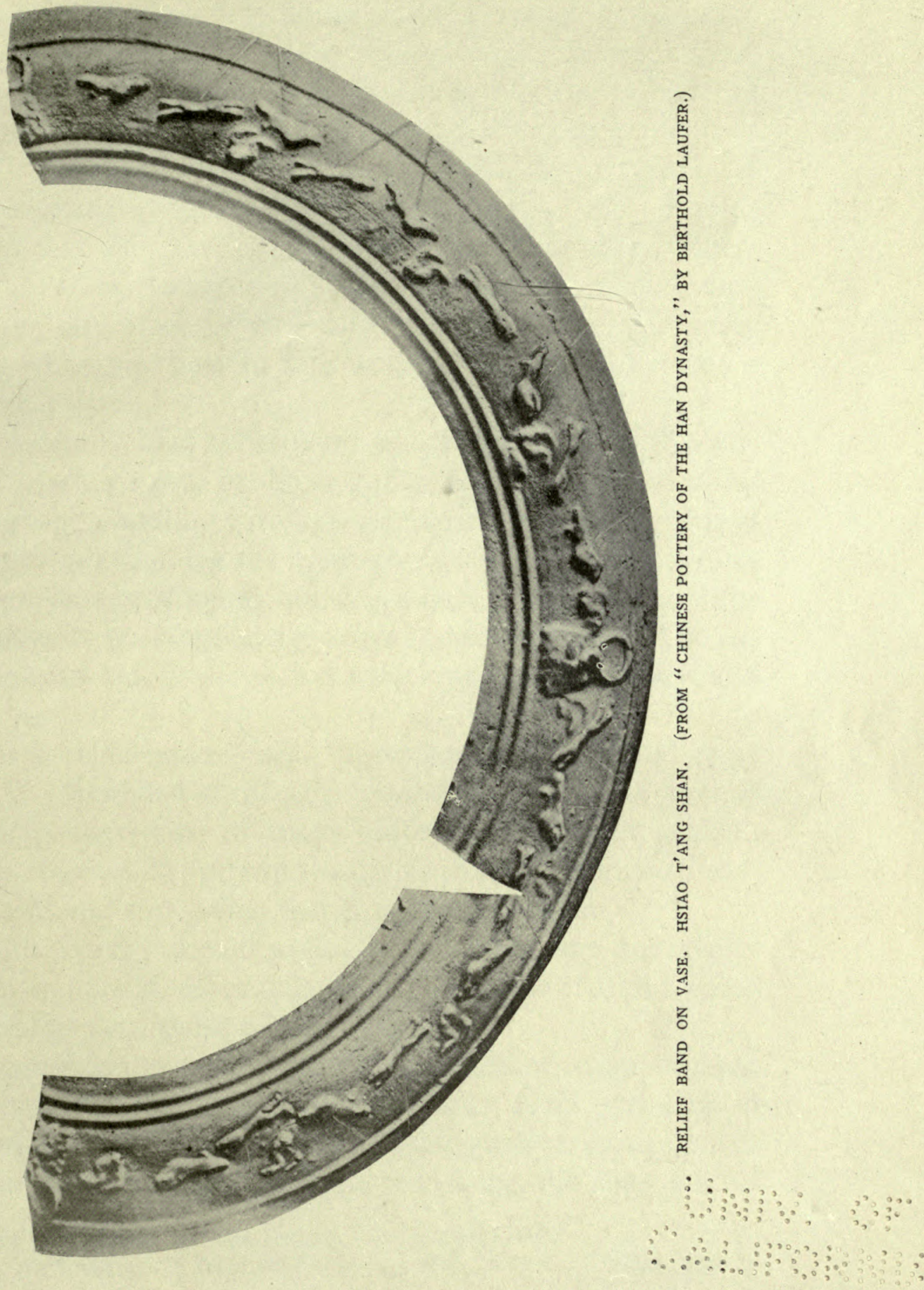

To face p. 56 



\section{SPORTING AND GUARD DOGS}

clumsy body, its long protruding snout, the shape of its head, and its short, erect tail." The dogs, galloping ventre à terre, are described by Laufer as greyhounds, but the tail of the conventional representation is thick, and the body too sturdy for such a breed, which, moreover, would be a type light for the hunting of game of such weight as the boar. Laufer suggests that the four scenes on the first * of these reliefbands illustrate consecutive stages of the same chase, thus describing the story of the same dog pursuing and finally reaching the same boar in four scenes, which thus become a " moving-picture."

The second $†$ Han relief-band illustrates tigers, with welldefined black stripes, in flying gallop and trotting. A rider on horseback, shooting with bow and arrow, a galloping hound in pursuit, and what may be a hare or a deer. Laufer describes this scene as a greyhound hunting a hare " characterized unmistakably by his long, upright ears and short tail." The socalled greyhound, however, has a thick neck, sturdy body, and broad tail.

A third relief-band $\ddagger$ also represents a "galloping greyhound." Another $\S$ of the same period includes three hounds "hunting stags, two of them unfortunately much effaced, but the other so happily drawn, with its long, pointed head, big breast, and thin loins, that it is unmistakable."

A fifth band $\|$ includes tigers and what are apparently dogs having short, erect tails, short legs, and of build much more sturdy than those hitherto shown.

Though it is not possible to define the exact points of these early varieties of the canine race these Han potteries, in addition to their vivid interest as artistic studies, certify to the fact that pursuit of the tiger, the wild-boar, the deer, and of

" " Chinese Pottery of the Han Dynasty," Laufer, plate xlvi.

$\dagger$ Ibid., plate xlviii. $\ddagger$ Ibid., plate xlix $\$$ Ibid., plate $1 . \quad \|$ Ibid., plate lii. 


\section{DOGS OF CHINA AND JAPAN}

the hare with dogs was a pastime current among the ancient Chinese. The breeds in use were, no doubt, adapted to some extent to counter the ferocity, strength, speed, and elusive powers of each quarry respectively in a land which was gradually being denuded of forests and entering a state of close cultivation.

The name of the chow breed of dog appears to have originated from "pidgin" English, which, now rapidly disappearing, was a trade language composed of a mixture of the most easily intelligible English and Chinese words used in early trade intercourse in South China. In this mixture there was originally a large element of Portuguese. Some suggest that the word originated as pidgin Portuguese, derived from "che," the Chinese for " to eat," used as the first word in the customary Chinese greeting, which means "Have you eaten rice?" At one period the Chinese, whose trade in ginger, or "chow-chow," with Europeans was important, became known by the name of chow. It is, therefore, probable that the name chow, as applied to the dog commonly found in Canton, simply means a Chinese dog, and does not refer to its having been used for food.

To the Western observer, the Chinese appear to have been far more successful in modifying the colour and form of canine breeds than in improving the powers of scent and sporting qualities of their dogs. This is no doubt largely due to the fact that for the last hundred years China has, from the point of view of sport, gone backwards. The Imperial hunts have been given up, preservation of the Imperial hunting-parks and game protection have ceased throughout China. The shot-gun, known to the Emperor Ch'ien Lung-to whom a specimen now to be seen in the National museum in Peking was sent by George III of England-though made in China is used for commercial $5^{8}$ 





$\because \because$ 


\section{SPORTING AND GUARD DOGS}

rather than for sporting purposes. When shot with it the game is more often sitting than on the wing. Powder and shot are too expensive, and their supply to a mis-ruled people under a weak Government is not encouraged. Consequently, it is not surprising to find in China but little of that care and skill which are devoted to the training of sporting dogs in Europe.

The existence of modern game laws is unknown through the greater part of China, and such as exist are not known ever to have been honoured in the observance. They were drafted by officials having no knowledge of natural history, and, partly, no doubt, on account of the vast area to be covered, where published, have never been taken seriously.

Under the Chinese Emperors, preservation of game in the hunting-parks appears to have been very strict. Even in recent years poachers of Imperial deer were punished with death. Settlement on the Imperial preserves, which in the case of the Northern hunting-park comprised an area approximately equal to that of England, was strictly prohibited, and a large guard of soldiers was maintained to prevent encroachment. Marco Polo states : "For twenty days' journey round the spot nobody is allowed to keep hawks or hounds, though anywhere else whosoever list may keep them. And, furthermore, throughout all the Emperor's territory, nobody, however audacious, desires to hunt any of these four animals, to wit, the hare, stag, buck, and roe, from the month of March to the month of October. Anybody who should do so would rue it bitterly. But those people are so obedient to their lord's command that even if a man were to find one of those animals asleep by the roadside he would not touch it for the world! And thus the game multiplies at such a rate that the whole country swarms with it, and the Emperor gets as much as he could desire. Beyond the term 


\section{DOGS OF CHINA AND JAPAN}

I have mentioned, however, to wit that from March to October, everybody may take these animals as he list."

Many writers have suggested, basing their opinions upon translations from Polo's work, that the dogs employed in these Imperial hunts were of mastiff breed. Some have gone so far as to suggest that, in consequence, they must have come from Tibet. It appears likely that the word used by Polo represented merely dogs having considerable size, strength, and hunting instinct such as were found in Europe and were used for hunting heavy game.

The French word from which "mastiff" is derived indicates a mixture in the dog's race. Its earliest types were found both in Gauland Britain. This race helped no doubt to produce the hunting dogsfor which Britain was justly famous in mediæval times. In I540 Henry VIII's envoy to the King of France wrote: "The Constable took me to the King's dinner, whome we found speaking of certain 'masties' you gave him at Calais, and how long it took to train them; for when he first let slip one at a wild-boar, he spied a white horse with a page upon him, and he took the horse by the throat and they could not pluck him off until he had strangled it. He laughed very heartily at telling this, and he spoke of the pleasure he now takes in shooting with a cross-bow, desiring to have a hound that would draw well to a hurt deer. Your Majesty's father sent to King Lewis a very good one of a mean sort. I hear you could not do him a greater pleasure than send him such a hound."*

This dog, however, has changed in modern times. "The mastiff of Tibet was larger than the old English (whose ears were formerly often semi-erect), but is smaller than the modern English mastiff, averaging 27-30 inches at the shoulder." This evolution modifying the dog's form to " "Calendar of State Papers. Henry VIII." 


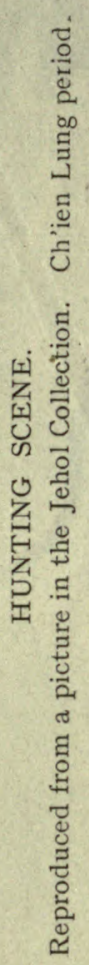





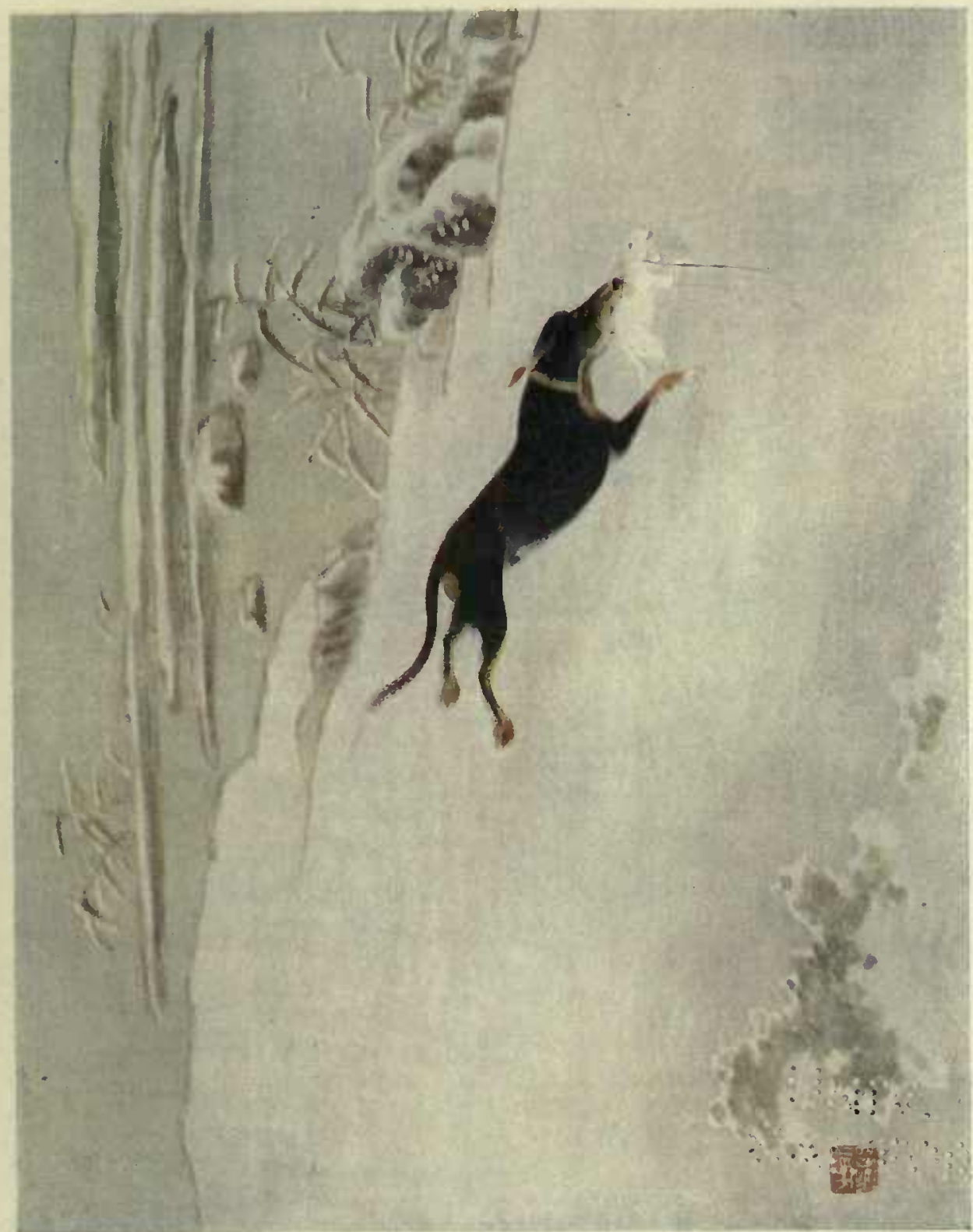

$\because \because$

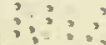


a! 


\section{SPORTING AND GUARD DOGS}

the purpose for which it has been from time to time most useful has ended in the race becoming fixed by the modern show-system as a guard-dog. "The modern mastiff has an excellent nose but is of little or no use for sporting purposes." * This type of dog cannot be the same as that which existed in the sixteenth century.

The Chinese Imperial hunts have been given up for a century and upkeep of the dogs has long since ceased. It

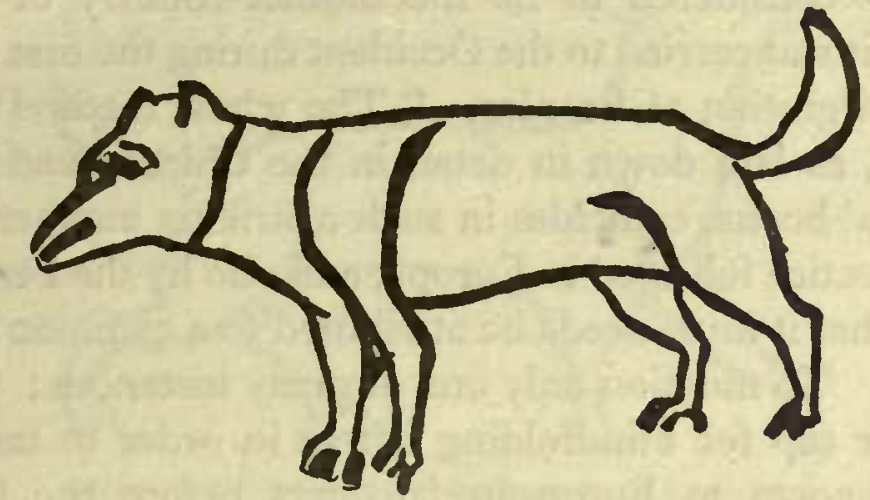

HOUND REPRESENTED ON HAN BAS-RELIEF OF THE HSIAO T'ANG SHAN (BROM A RUBBING)

may be that specimens may be found with the chiefs of some of the Mongol tribes but with the gradual extinction of the big game of China it is unlikely that many of the hounds exist.

Representations of these hounds are found in certain pictures of the $\mathrm{K}$ 'ang $\mathrm{Hsi}$ and Ch'ien Lung period from Jehol.

Laufer figures hunting-dogs of the Han period from rubbings taken from bas-reliefs at Hsiao T'ang Shan. These may be roughly dated I50 B.C. One of these bas-reliefs, of colossal size, shows eight hunters afoot, carrying nets over their shoulders and eight dogs preceding them.

"All the aforementioned greyhounds and hunting-dogs

" "Chambers' Encyclopædia." See Rev. M. B. Wynn's " History of the Mastiff," 1886. 


\section{DOGS OF CHINA AND JAPAN}

have smooth-haired tails; only two (on the bas-reliefs of the Hsiao T'ang Shan) are represented with bushy tails, the hair being drawn in an ornamental and much exaggerated manner on the lower side of them." *

Turning now to fowling, Laufer is of opinion that Chinese culture in hawking has been derived from Turkish tribes. He states that Schrader, $\uparrow$ from a study of the history of falconry in ancient Europe, has demonstrated that Turkistan must be considered to be the mother-country of falconry, whence it was carried to the Occident during the first invasions in the Migration of Peoples. "The whole method of hawktraining, as laid down in detail in the Chinese and Japanese falconers' books, coincides in such a striking manner with the same practice followed in Europe, and also by the Persians and Arabs, that it must needs be attributed to a common source of origin.f To mention only one of many instances : the hood, a leather cap for blindfolding hawks in order to tame them, was unknown to European falconers before the Crusades. It was introduced by the German Emperor Frederick II, who adopted it from the Syrian Arabs. $\S$ The use of the hood has been well known to Chinese falconers since times of old, and is still prevalent in China. The origin (of falconry) can be sought only in the vast steppes of Central Asia and in the culture of the ancient Turks." $\|$

This statement is based upon discoveries of silver objects in Siberia, upon which falconry and the use of huntingbirds are represented, believed to date from as early as the later iron period. Klementz made a find of a wall-painting

" "Chinese Pottery of the Han Dynasty," Laufer, p. 272.

† Schrader, "Reallexicon der indogermanischen Altertumskunde" (Strassburg, rgor), p. 2 Ir.

I For an account of the modern use of hawks in Japan see "Japan Day by Day," by $\mathrm{Ed}$. S. Morse, vol. ii, p. $38 \mathrm{r}$ et seq.

$\S$ "De Arte Venandi cum Avibus," 1245.

|l Laufer, "Chinese Pottery of the Han Dynasty," p. 23 r.

62 


\section{SPORTING AND GUARD DOGS}

representing two figures of men, one of whom seems to be carrying a falcon, in a cave near Turfan in Turkistan.*

"In China, hawks, eagles, and other large birds of prey, are early mentioned in the 'Shih king' and in the ' $\mathrm{Li} \mathrm{ki}$,' particularly in poetical comparisons ; but in classical literature no mention is made of falconry or of the training of birds for the chase, which seems to have come up not earlier than



FIGURE OF DOG ON HAN BAS-RELEF OF HSIAO T'ANG SHAN

the Han dynasty, and soon developed into the favourite sport and pastime of emperors and noblemen." $\dagger$

Marco Polo describes the Emperor's method of fowling with falcons and other hawks: "And let me tell you, when he goes a-fowling with his Ger falcons and other hawks he is attended by full 10,000 men who are disposed in couples. Every man of them is provided with a whistle and hood, so as to be able to call in a hawk and hold it in hand. And when the Emperor makes a cast there is no need that he follow it up, because these men I speak of keep so good a look-out that they never lose sight of the bird, and if these have need of help they are ready to render it." $\ddagger$

\footnotetext{
* " Expedition nach Turfan," St. Petersburg, 1899.

+ " Chinese Pottery of the Han Dynasty," Laufer, p. 232.

I "Marco Polo's Travels," Yule.
} 


\section{DOGS OF CHINA AND JAPAN}

Laufer states further : "The oldest representation of falconry in China is found on one of the Han bas-reliefs of the Hsiao t'ang shan.* A man on foot holds a falcon on his right fist ; and a greyhound is hunting a stag in front of him. The next in point of time are two wood engravings in the dictionary 'Erh-ya,' $\dagger$ which may be stated to present a rather faithful copy of the illustrations to this work extant in the fourth or sixth centuries. At all events, it may lay just claim to the honour of being the oldest graphic book-illustration of falconry in the world; the oldest English (and altogether European) representation $\downarrow$ being from an AngloSaxon manuscript of the end of the ninth century or beginning of the tenth, preserved in the British Museum. While the oldest Chinese book on falconry seems to come down from the Sui dynasty (A.D. 518-6I7), the first European print on the subject is the German book of Anon, printed in Augsburg in $1472 . "$

Though Kaempfer remarks of the Japanese : "They hunt but little and only with common dogs, this kind of diversion being not very proper for so populous a Country, and where there is so little game," Capt. John Saris wrote about eighty years earlier of the "Captain Generall" of the garrison of Fushimi : "Hee marched in very great state, beyond that the others did. He hunted and hawked all the way, having his owne Hounds and Hawkes along with him, the Hawkes being hooded and lured as ours are. Their horses are not tall but of the size of our midling nags, short and well trust (trussed), small headed and very full of mettle, in my opinion far excelling the Spanish Iennet in pride and stomacke." $\S$

"Chavannes, "La sculpture sur pierre en Chine," p. 77, and plate xxxviii.

$\dagger$ Book II, p. $23 b$.

Joseph Strutt, "The Sports and Pastimes of the People of England," new edition, London, r898, p. 88, Fig. 3 .

$\S$ "Voyage of John Saris," Hakluyt Society, 1612-1613. 64 


\section{SPORTING AND GUARD DOGS}

Arkwright * remarks that the first European reference to dogs " which know of beasts and birds by the scent," dates from about A.D. I260, and opinion appears fairly unanimous that they came from Spain; " as one talks of a greyhound of Britain, the boarhounds and bird-dogs come from Spain," remarks an early writer quoted by the same authority. Another writer remarks that Robert Dudley, Duke of Northumberland, born in $\mathrm{I}_{504}$, who "was a compleat Gent. in all suitable employments," was " the first of all that taught a dog to sit in order to catch partridges." * This, no doubt, was the method practised with the spaniels $\uparrow$ mentioned fairly frequently in English records of the time of Henry VIII. The sporting spaniels were originally large dogs and became modified to pointers by selection and cross-breeding. "No hound or greyhound, spaniel or other kind of dog to go in the streets by day unless " hardeled or ledde in leses or lyams or otherwise, so it be no "noyance" under pain of forfeiture to the taker and a fine of $4 \mathrm{~d}$. to the owner." " And again, Robin the King's Majesty's spaniel keeper, was paid 56s. 9d. " for hair cloth to rub the spaniels with and for meat and lodging at Maidenhead and Windsor and at Putney, when the King dined at my lord of Hartfordes." $\ddagger$

The figure from Laufer's "Chinese Pottery of the Han Dynasty," which is a composition from rubbings from a basrelief of the Han period, represents a form of sport practised in China to this day. Whether or not the possession of

" "The Pointer," W. Arkwright, pp. 6 and ro.

† Spaniel. Murray gives the forms spaynel, spanyel, spayngyel (old French espaignol, espaigneul," Spanish dog"), spaignol. First mentioned 1388. Chaucer, "Wife's Prologue," p. 267 : "For as a spaynel she wol on hym lepe," 1410. "Master of Game" (M. S. Digby, p. 182): "A goode spaynel shulde not be to rough, but his tail shulde be rough." 1621. Burton, "Anat. Mel." : "Like a ranging Spaniel that barkes at every bird he sees." Spaynel and spanyell were also used in the fourteenth century = a Spaniard.

f "Letters and Papers," I 542 and 1546. 


\section{DOGS OF CHINA AND JAPAN}

powers of scent for birds is indicated must remain a matter for conjecture, and the dogs are somewhat roughly drawn.

On the right are two pedestrians carrying bird-nets of the size now used in taking quail in China. Before them are two hounds having rather bushy tails, erect ears, and long muzzles, galloping in pursuit of two hares, identified by their short tails and long ears. On the left another hunter holds a greyhound in leash. Above the hares is depicted a dog, apparently in quest, but conceivably at point. Above the greyhound is a bird, probably a hawk, hovering.

The taking of quail with nets of exactly the shape represented, and with dogs of "chow" type, having rudimentary scent and point, may be seen in use by native hunters in many parts of China to-day. Pheasants also are captured in the same way, a hawk being sometimes used to prevent the quarry from rising or running. Hares are captured in similar fashion.

The following is the Chinese description of a hawkingparty carried out by one of the Manchu nobles in recent times. Such parties were common in the district to the north-west of Tientsin about 1895 :

The assistants were eight in number. Two rangers led the party from a distance. Their special function was discovery of the "form" of the hare. Six men in charge of hawks and dogs were spread out fan-wise behind, their masters following the party on horseback or on foot, carrying their long-barrelled guns. Of the six men in charge of the dogs and hawks two held the hounds, rather thickerbuilt than the foreign greyhound, in leash. Two, one on either side, carried large hawks (t'u hu-lit. " hare falcon"; the name is sometimes applied to the goshawk) at their wrists, and two at either extremity of the line carried sparrowhawks (yao, female of accipiter nisus; the name is also applied to accipiter gularis). On discovering a hare the 66 


\section{SPORTING AND GUARD DOGS}

ranger blew a sharp blast upon his whistle. The visor of the hood of each of the large hawks was then lifted, but the hood, bearing a red tassel at its tip, was left in place. The sparrow-hawks were then released. Each of these, taking the red tassel of the nearer hawk's hood in its beak, tore off the hood. The large hawks were then released, and the hare being started, followed it, one on either side,

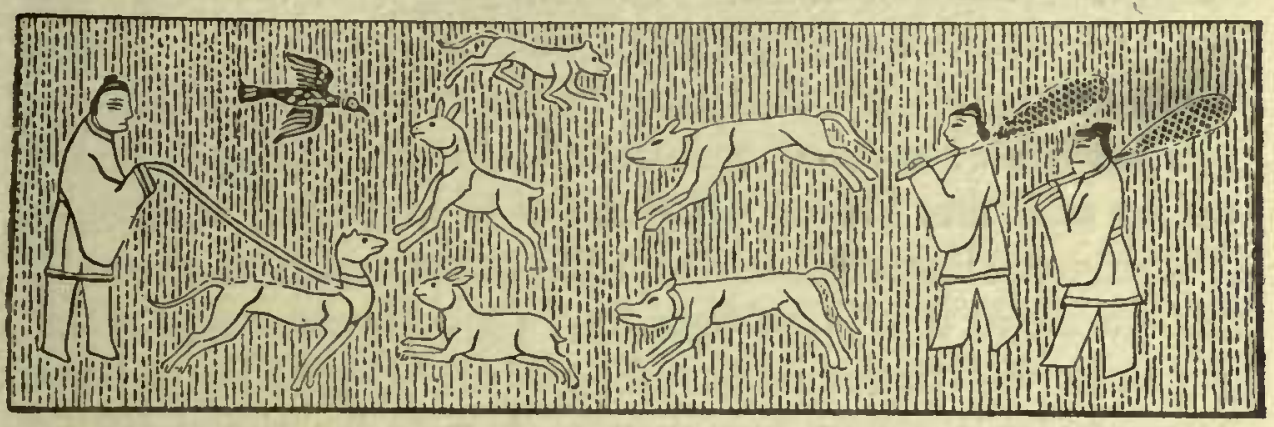

FIGURES OF HUNTING-DOGS ON HAN BAS-RELIEF (FROM KIN SHIH SO)

stooping alternately, each hawk beating it with the (tai) ball of its talon so loudly as to be heard at one or two hundred yards' distance. After a certain amount of this treatment the hare lay down exhausted. The hawks then hovered, one on either side. The dogs meanwhile had been released. On reaching the hare they lay down, one on either side of the hare. The hawks alighted on their backs, waiting for the huntsmen. On their arrival the hind-legs of the hare were drawn back with a crook and broken by a sharp blow with a narrow rod. The hare was then killed and a little of the flesh given to each of the hawks.

Should the hare have broken for cover when put up it would have been coursed with the dogs, the hawks being held back for fear of injury in thorny bushes. If released they would have perched near the wood on guard. In taking 


\section{DOGS OF CHINA AND JAPAN}

the hare in such difficult ground the gun would be used. In open country use of the gun is unnecessary. The gun being a match or flint-lock it was almost impossible to shoot birds on the wing. A hawk commonly used in the catching of hares in China is the huang ying (lit. yellow eagle-Astur palumbarius, the goshawk), which fixes its talons in the sides of the hare and is dragged with spread wings until the quarry is exhausted. The chi-ying (lit. bird-eagle) is the male of the huang-ying and weighs about $2 \frac{1}{2} \mathrm{lbs}$. Being small of body it is suited only to the catching of pheasants.

The Han bas-relief mentioned above was found in the village of Chiao Ch'eng Chi, west of Chia Hsiang in Western Shantung. The explanation of the scene depicted, made by the editors of the "Kin Shih So," the Chinese work, ${ }^{*}$ from which the illustration is derived, reads: "On the lower panel one man leads a dog, two men carry nets for the quail. A pheasant and a hare are running at full speed, for it represents a hunt." This, however, must not be taken more seriously than the remarks of other Chinese literary commentators written at late periods with a view to elucidation of technical subjects of which they had no special knowledge.

Use of the fowling-piece and the art of shooting flying only came into being in England about the year 1725. $\dagger$ In Europe hawking had been superseded by the netting of partridges with the spaniel trained to set at the birds and to cause them to allow the net to be drawn up to and over them. Hawking, the netting of quails, francolins, or partridges, and pheasants, as well as the use of the muzzle-loader and breech-loader sporting-guns are all practised side by side in China by the natives to-day. In South China the capture of birds is less

"Vol. iv., section "Shih So."

$\dagger$ Notes and Queries, 2nd series, v, p. 306; and Edinburgh Review, August I825, vol. xliii, p. 457 . 


\section{SPORTING AND GUARD DOGS}

practised than in the North, on account of the idea that birds exercise good geomantic influence over the country. Notices are often posted in Southern villages to the effect that neither birds nor the trees on which they roost are to be destroyed.

In Chinese fowling the faithful chow, or a close relation, ranks a good second to his master in the operation of capture. Ever distrustful of strangers, he is the faithful guardian of his village, wakeful and noisy at night, sleepy and persecuted during the day. Some claim for him on occasion the qualities of that deadly class of dogs " which bite bitterly before they barcke, for they flye upon a man, without utterance of voyce, snatch at him, and catch him by the throate, and most cruelly byte out collopes of fleasche." * He is brave in the defence of his home, keen of nose, and untiring in the chase, though sorely oppressed by the warmness of his heavy coat, necessary as a protection against the thorns and prickly creepers which tangle his native thickets. His powers of scent are used to-day in the capture of birds for the table, just as, in all probability, before the European bird-dog was invented, they availed the oriental hunter in the capture of antagonists in the favourite Chinese sport of quail-fighting. His staunchness at " point " may be but slight. Sportsmen, however, who know him will agree that the chow or the pointer-cross is best fitted to stand the rigours of the China climate, and that in his native thickets and tangled clearings he will, by his forceful tactics, behind such inveterate runners as the strong-sinewed Mongolian pheasant or the swift-legged francolin of Yunnan, bring birds to the gun, while the staunchness of the foreign pointer distinguished in field-trials, brings seeming mockery from the pursued, and is to the fowler little less than a delusion.

White, in 1802 , writes of the importation of a pair of dogs,

* Dr. Caius, Abraham Fleming's translation quoted in " Praise of the Dog," Ethel E. Bicknell. 


\section{DOGS OF CHINA AND JAPAN}

evidently chows, from Canton. He says they were " such as are fattened in that country for the purpose of being eaten; they are about the size of a moderate spaniel ; of a pale yellow colour, with coarse bristling hairs on their backs ; sharp upright ears and peaked heads, which give them a very foxlike appearance. Their hind-legs are unusually straight, without any bend at the hock or ham, to such a degree as to give them an awkward gait when they trot. When they are in motion their tails are curved high over their backs like those of some hounds, and have a bare place on the outside from the tip midway, that does not seem to be matter of accident but somewhat singular. Their eyes are jet-black, small and piercing; the insides of their lips and mouths of the same colour, and their tongue blue. When taken out into a field the bitch showed some disposition for hunting, and dwelt on the scent of a covey of partridges till she sprung them, giving her tongue all the time. These dogs bark much, in a short, thick manner, like foxes, and have a surly, savage demeanour, like their ancestors, which are not domesticated but tied up in sties, where they are fed for the table with rice-meal and other farinaceous food. These dogs did not relish flesh when they came to England." *

This is a good description, except for colour, which varies almost infinitely between jet-black and snowy white, for the breed as it exists in China to-day. Native hunters insist that his tongue shall be black.

Similar dogs are used for drawing sledges in Mongolia and the Ninguta and Sanhsing districts of Northern Manchuria. "The Tartar dogs are much valued, and deservedly ; they harness them to sledges which they draw over the snow and frozen rivers. 'We met,' says one of the missionaries, to whom we owe the map of Tartary, "a lady of Ussuri who

- White's " Natural History of Selborne," vol. ii, p. 77, 1802. 


\section{SPORTING AND GUARD DOGS}

was returning from Peking. She informed us that she had a hundred dogs for her sleigh. One goes in front as guide, those in harness follow it without turning aside, halting only at certain points, where they are exchanged for others taken from those held in leash. She maintained that she had often made a continuous journey of roo li ( 30 miles).' " *

Similar, no doubt, is the race of dogs said by Griffis $\dagger$ to be the only animal domesticated by the Ainu of Japan. He says they are taught to hunt bear and deer, to watch on the shore for the incoming salmon, to rush into the water, drive the fish, bite off the salmon's head, and to leave its body at his master's feet.

The breed appears to extend North into Tibet, for Percival Landon describes the dogs which swarm over that country and form one of its principal features as being of a type " rather that of the Esquimaux sledge-dog." $I$

Dr. Wells Williams states that "In Anhui a peculiar variety (of dog) has pendent ears of great length and thin wirey tails." $§$

Some writers mention Chinese crested dogs and a hairless dog. The hairless type appears to be as elusive as the "Raccoon dogs of China and Japan," $\|$ and the naked dogs of Turkey and Egypt. The Zoological Society records that a hairless Egyptian variety of the familiar dog died in its garden in 1833. Buffon described a dog naturally destitute of hair under the name " Le Chien Turc." Later writers state that the race is unknown in Turkey. Others deny that a hairless Egyptian race has any existence.

" Grosier, "De la Chine," vol. iv, p. 244.

† W. E. Griffis, "The Japanese Nation in Evolution," p. 9. For a similar use of the dog in salmon-fishing in Britain, see Pinkerton's "Voyages," vol. ii.

I "Lhasa," Percival Landon, p. 387.

"Middle Kingdom," vol. i, p. 3 rg.

\|I Proc. Zool. Soc., 1868, p. 492. 


\section{DOGS OF CHINA AND JAPAN}

\section{The Greyhound, Wolf-hound, and Kansu Greyhound}

Existence of the greyhound at an early period in Shantung Province is proved by a rubbing * from a bas-relief of the Han period at Wu Liang in Shantung Province. The greyhound, which is altogether unmistakable, is described by Laufer as sitting on the ground in front of a carthorse, a man standing on its left, and as seeming to belong to the people driving in the cart. The same figure of a greyhound, in exactly the same posture, is delineated on another bas-relief, also here squatting in front of a cart whose horse has been unharnessed and is standing to one side under a tree, while a man, probably the teamster, is to the left in front of the dog.

In North China the "long-dog" is known as the hsi-kou or thin-dog, often qualified by the name Min-tzu, a prefecture in Shantung said to have been famous at one period for the breed. The legendary Heavenly Dog is represented as being of this breed. The term is probably the antithesis to that of the "short-dog," introduced from the Southern Shansi States about 1000 B.c. $\dagger$

Both rough and smooth-coated varieties of the dog exist, and they closely resemble the British race. The known frequency of intercourse between Eastern monarchs renders it probable that this dog is akin to the Persian greyhound, of which race a specimen reached England before $185^{8}$. It was used in hunting the wild-ass and antelopes as well as the coursing of hares. On the cutting of the crops of maize, millet, and wheat in the vast plains north of the Yang-tse, numbers of hares are left without cover. The villagers spend their spare time coursing them with these dogs. The European dog is acknowledged to be superior to the Chinese, and is said to

"Chavannes, " La Sculpture en Pierre en Chine," plate xxv.

+ Chap. i, p. 16. 


\section{SPORTING AND GUARD DOGS}

have been crossed with it to improve the breed. English greyhounds were famous in Europe, and an article of export in the fifteenth century. In I 47 I the following "instructions and orders" were given to Francisco Salvatico, Councillor of the Duke of Milan, about to go to England :

"We desire you to obtain some fine English hackneys of those called 'hobby' for the use of ourself and the duchess our consort, as well as some greyhounds for our hunting, a laudable exercise in which we take great delight, and so we have decided to send you to England where we understand that each of these things is very plentiful and of rare excellence. We are giving you a thousand gold ducats for the purpose to buy the best and finest horses you can find and dogs also. In order that you may find and buy them more easily we are sending with you el Rossetto, our master of horse, and two of our

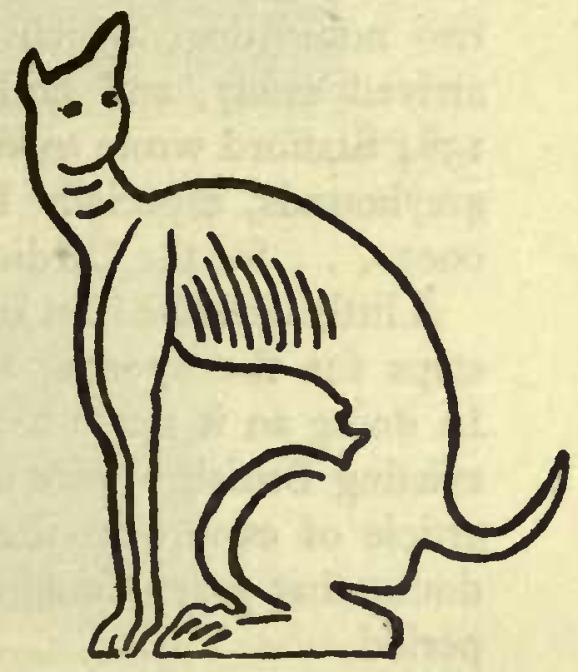

GREYHOUND REPRESENTED ON HAN BASRELIEF OF WU LIANG IN SHANTUNG Chavannes: La Sculpture en Pierre en Chine. dog-keepers, who know our tastes and the quality of horses and dogs that we require."

Salvatico was unfortunate enough to fall into the hands of the Duke of Burgundy at Sluys, where he was consigned to the castle and "stripped of all his letters and things," but after diplomatic representations was released. Two months later he wrote from France that he was " much perplexed as to what to do, with English affairs in their existing state," and that he was " all ready to go and also to proceed to Ireland, whence all the hackney (obico) horses come."

Five years later there was transmitted to King Edward a 


\section{DOGS OF CHINA AND JAPAN}

letter from the Duke of Milan to his Ambassador: "We were especially fond of Brebur, whom the King sent, but whether from change of air or some other accident he fell sick, and though we gave him every care he died. This has caused us much grief. We beg His Majesty to send another dog of the same race, as nothing would give us greater pleasure. We send the present bearer for no other reason." Sforza, the Duke of Milan, wrote to King Henry in 1487 : "The two noble dogs which we desired from your island have arrived safely, and nothing could please us better." * In I584 Stafford wrote to Walsingham to "entreat you for some greyhounds, especially Irish, or the largest sort of English ones ... f for the Cardinal de Medicis." †

A little later the East India Company began to take energetic steps for the opening up of trade with Japan and China. In doing so it made use of the high reputation of the then existing British breeds of dogs, and they became a common article of export on the British ships. There can be little doubt that greyhounds from England reached China at this period.

In 1614 Captain Saris recommended the sending of a "fine greyhound" to the son of the Daimio of Hirado. In the same year the Governor of Surat requested the East India Company to send as presents for the Great Mogul "looking-glasses, figures of beasts or birds made of glass, mastiffs, greyhounds, spaniels, and little dogs."

In $16{ }_{5} 5$ the Company's factor wrote that King James's letters had been delivered to the King of Acheen and other parts of Sumatra, and suggested " a corslet and helmet will be well accepted by him; he takes great delight in dogs, and also in drinking and making men drunk." The King of Acheen replied to King James begging him " to send him ten mastiff

$$
\text { * "Calendar of State Papers," Milan, 147r. † Ibid., 1583-4. }
$$




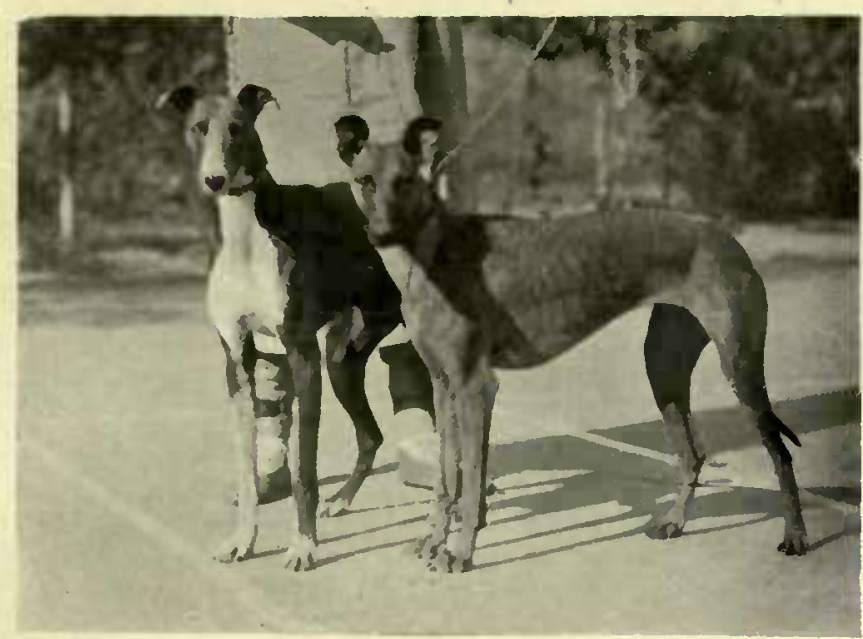

KANSU GREYHOUNDS

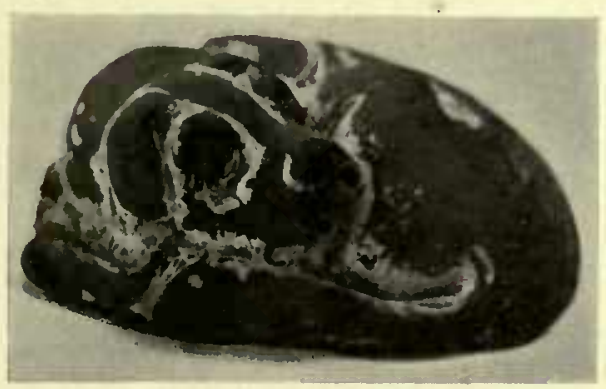

MASTIFF TOMB-DOG, IN TERRA-COTTA.

TANG PERIOD. (AUTHOR'S COLLECTION)

PRESENTED BY KUNGPAH, T. KING, ESQ.

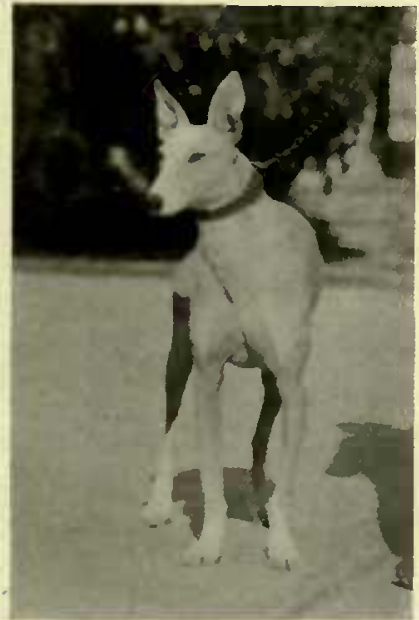

KANSU GREYHOUND

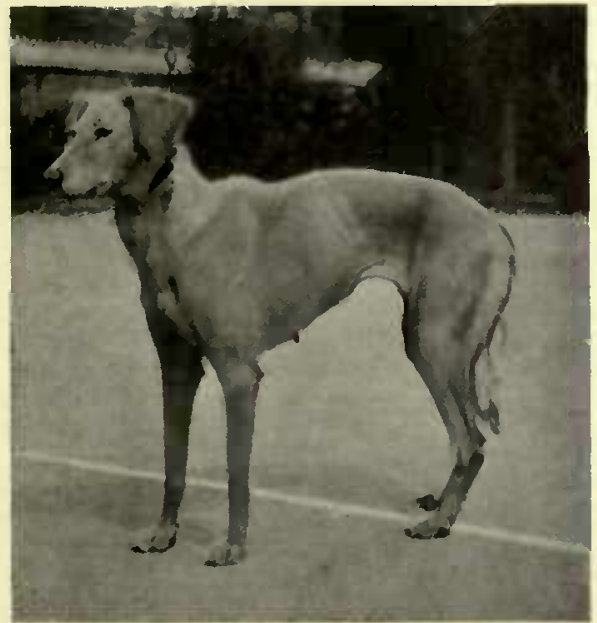

CHINESE ROYAL-COATED GREYHOUND PEKING

$$
\begin{aligned}
& \text {; Fofale } \$ 74^{\circ} \quad \because \because: \cdots \\
& \text {...?:? } \\
& \text { 0? }
\end{aligned}
$$

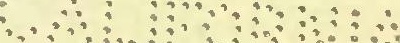


$\because \vdots \because \quad \because \vdots \vdots \vdots \vdots \vdots \vdots \vdots \vdots \vdots 0$

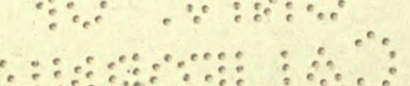




\section{SPORTING AND GUARD DOGS}

dogs and bitches, with a great gun, wherein a man may sit upright." *

A separate Chinese variety is known as the Hsi Yang Mintzu, and comes from the Mahommedan districts of Kansu and Shensi, where it is used for bunting hares and foxes. It is a diminutive greyhound, short-coated, beautifully proportioned, of distinctive type and breed. A large variety is said to exist. Three specimens were brought to Peking in I9I4. Measurements of two of these are appended.

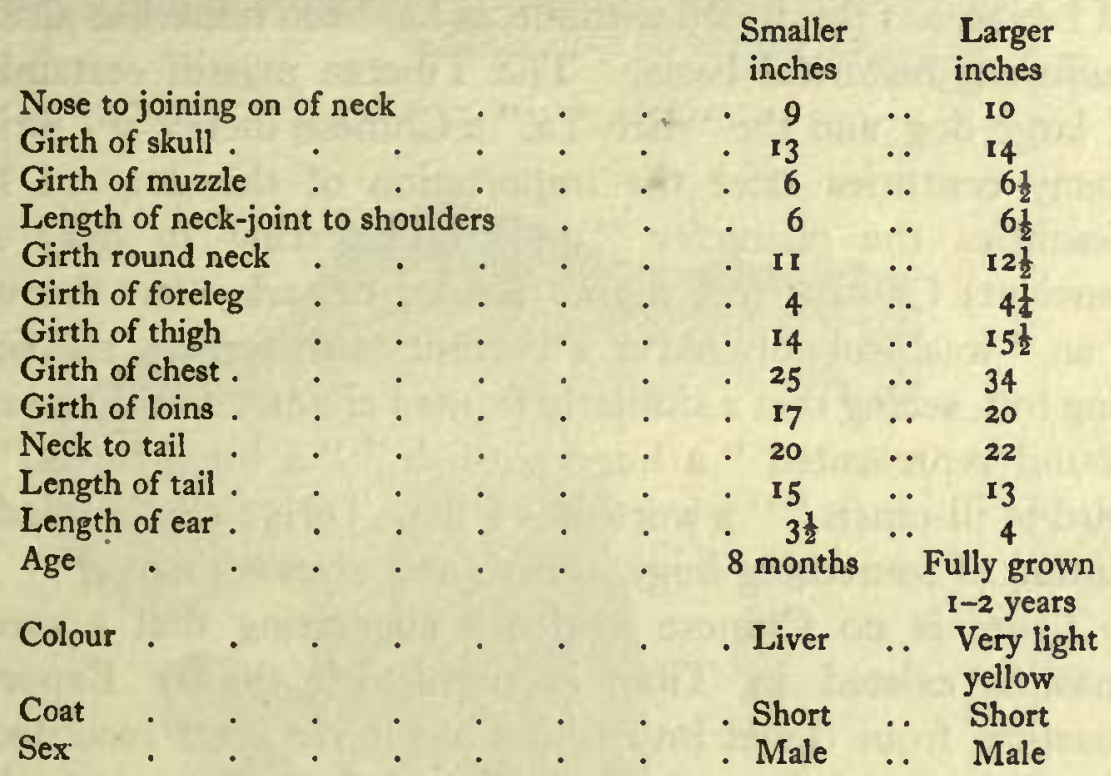

A kindred breed of coursing dog is the Chinese wolf-hound, which is found in the encampments of the Mongolian princes, and is used for hunting wolves and foxes. Many of the chiefs have from 40 to 50 couple of these hounds. Few have been seen by Europeans. They are said to be similar to the Borzoi. Two of them were brought to Tientsin some years ago and are remembered, when escaped from their keepers, as having captured a Pekingese dog which was unfortunate enough to

" "Calendar of the State," East Indies, $15^{1} 3^{-1625}$. 


\section{DOGS OF CHINA AND JAPAN}

cross their path, tearing it to pieces and devouring it on the spot.

"The hunting-dogs are clever in seizing wild animals, and are kept in great numbers in Mongolia. These are the ' hunting-dogs higher than stags' that Chou Po-ch'i of the Yuan dynasty mentions in a poem in his 'Diary of a Journey to the Capital.' " *

Nothing is known of the origin of the Tibetan mastiff. German writers have assumed that the " ao " dog of the tribes of Leu was of this breed without, as has been remarked already, sufficient historical basis. The Tibetan mastiff certainly is a large dog and the "Erh Ya," a Chinese dictionary written many centuries after the importation of the dogs of Leu, describes the character "ao" as referring to dogs four (ancient) Chinese feet high. Laufer remarks that the word " ao " was probably never a current term for any species of dog but, seeing that a similarly formed character with the same sound represented " a huge sea-fish," " a huge turtle," " a bird of ill-omen," " a worthless fellow," originally implied the notion of something huge, weird, and extraordinary. $\dagger$

There is no Chinese evidence suggesting that a race of mastiffs existed in Tibet in prehistoric times. Export of mastiffs from Tibet into China has never been recorded by the Chinese nor have they mentioned the existence of a large race of dogs in that country which, originally the home of semi-nomad tribes, became consolidated under one ruler and known to history only in the seventh century A.D. That fierce dogs of large size existed in China in early times is proved by the discoveries of pottery figures of guard dogs in graves of the Han period. Laufer $f$ illustrates " the full figure of a dog of Han pottery, with green glaze which, for

" "Annals of Ch'eng te fu," Jehol, Book 29, p. $25 a$.

+ "Pottery of the Han Dynasty," p. 255. $\$$ Ibid., Laufer, plate lxiv. 


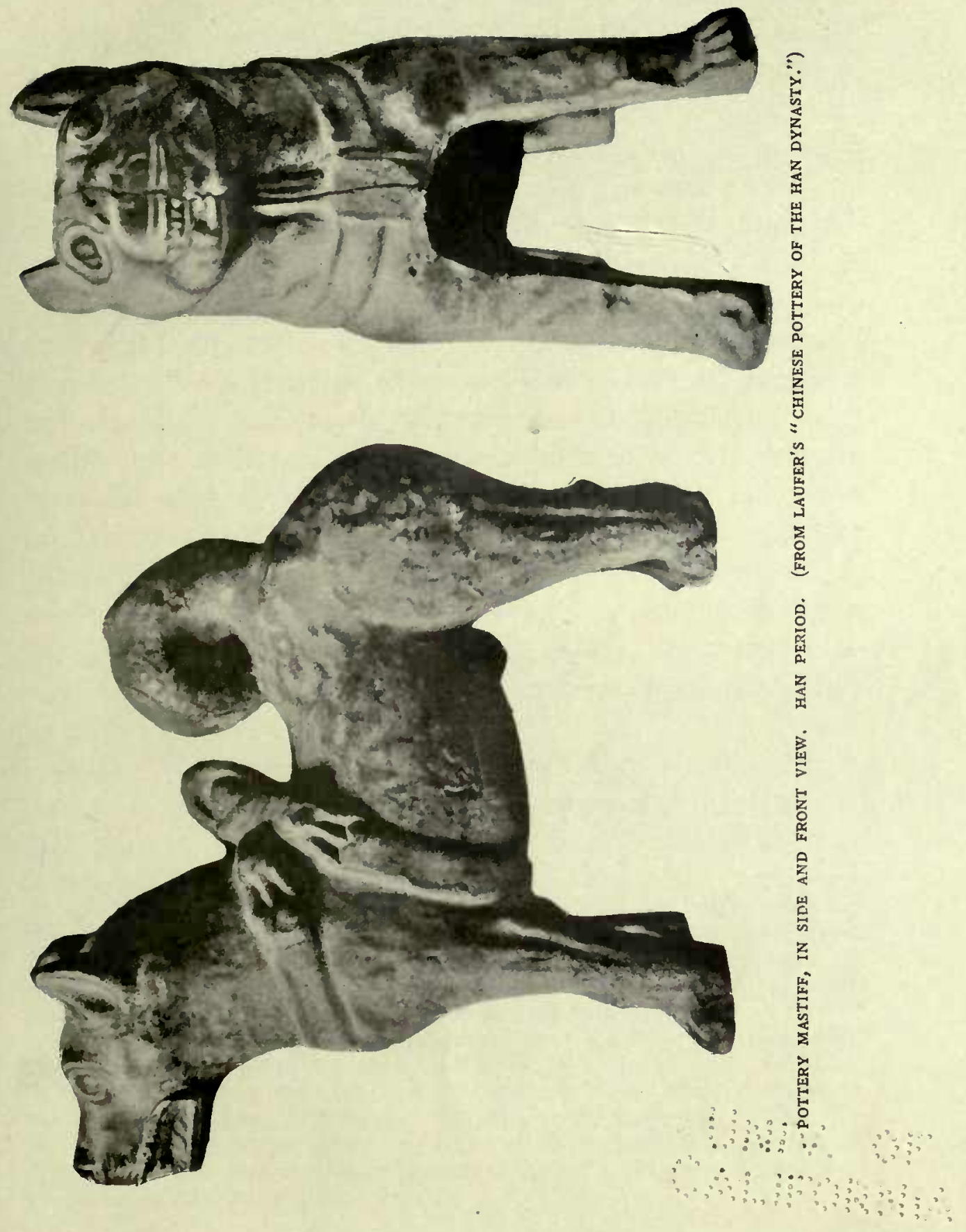





\section{SPORTING AND GUARD DOGS}

the most part, has dissolved into a silver iridescence." This dog is clearly a sturdy chow of a type commonly found in Yunnan Province. It has prick ears, bushy and well-curled erect tail, straight hind legs and non-pendulous lips, but large eyes and broad head. These tomb-dog figures have evidently been made in large numbers, usually on the cheap scale current in modern Chinese funeral offerings and grave furnishings. Strongly characteristic of these Han guardiandogs are the massive collar and body-straps which, by their stoutness, indicate that the guard-dog of the period was extremely powerful. In their form, neck and chest-band connected by a strap in front and bound into an iron ring over the back, they clearly originate the efficient harness with which the Chinese have been accustomed to hold their more powerful dogs in leash through historical times. The iron buckles at the side of the harness are strongly made and very characteristic. The tail in some of the clay specimens is bushy and well curled over the back.* In others, however, though curled, it is short and with no brush. Stiffness of the hind legs so characteristic of the chow breed is clearly shown in these models. $f$

It may be that these pottery tomb-dogs are the representatives of dogs which were in the possession of the deceased, and that at an earlier period the dogs themselves were

* The Assyrian dogs of Asshur-bani-pal wore plaited neck-collars. Judging from the reliefs and clay figures reproduced in Handcock's work, the curl of the tail of these dogs is open, and does not closely resemble that of the Tibetan mastiff breed. The ears are not pricked, but rather pendulous. The hind legs are not straight, and are bent in running. The suggestion by Layard that the Assyrian breed is still extant in Tibet (though not in Mesopotamia) does not seem justified.

$f$ "The only peculiarity that I have noticed about them (the Tibetan mastiffs) is that the tail is nearly always curled upward on the back, where the hair is displaced by the constant rubbing of the tail." A. Cunningham, "Ladak, Physical, Statistical, and Historical," London, 1854, p. 218. Cf. White on the chow dog: "When they are in motion their tails are curved high over their backs like those of some hounds, and have a bare place on the outside from the tip midway, that does not seem like a matter of accident, but somewhat singular." 


\section{DOGS OF CHINA AND JAPAN}

slaughtered that they might accompany their master's spirit in its journey. "All Americans believe in the soul's journey to another world and some speak of the bridge leading to heaven, and others of the Milky Way as the path of souls. The custom of removing the corpse by a special door, found among the Algonquins, is ancient in China and Thibet, and was once well known in Europe also. The dog slain at the tomb becomes the guide of the soul, as in Persia." *

The inclusion of dogs in burial ceremony can be traced back to the Copper period, when man was still using stone implements and had in Europe only two kinds of domestic $\operatorname{dog}(C$. palustris and $C$. intermedius). A young girl of the period has been found to be protected by four dogs' heads placed symmetrically with the fangs outwards and at the corners, below a circle of stones with animal bones. The soil was covered with a heap of small stones nearly six feet deep. Elliott remarks that this, no doubt, superstitious ceremony may have had something to do with the ever-present danger of wolves. The people who lived in this village belonged to the Cromagnon and Furfooz types. $\dagger$

A similar custom exists among certain African tribes at the present time, a dog being slaughtered at the burial of a chief.I It is believed that in Africa this dog-sacrifice has taken the place of the sacrifice of slaves or of enemies captured in war. The well-defined leading-harness appears to indicate that in China the idea was rather to provide a guide for the spirit through the darkness of the future existence. Similar harness may be seen on dogs leading the blind in China at the present day.

Clay figures of the human servitors of the deceased are

" "The Rise of Man," by C. R. Conder, I908.

$\dagger$ "Prehistoric Man and his Story," by G. F. Scott Elliott, r9r 5.

I "Ban of the Bori," by Tremayne. 




:

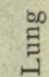

단

됭.

บ

ํㅡㄹ

녹

I

.

苛

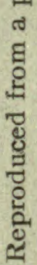










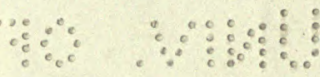

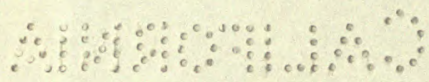




\section{SPORTING AND GUARD DOGS}

found in Japanese tombs. The Nihongi gives details of these burial customs: "The brother of the Emperor Suinin (29 B.C. to A.D. 70) died and was buried at Musa. All those who had been in his personal service were gathered together and were buried alive in an upright position around his barrow. They did not die for many days, but wept and bewailed day and night. At length they died and became putrid. Dogs and crows came together and ate them up." The Emperor, who had listened to the lamentations, ordered the abolition of this custom, and it is said that from the year A.D. 3 clay figures instead of human beings were buried in or about the barrows.*

"A large breed of dogs, so fierce and bold that two of them together will attack a lion (tiger)" is mentioned by Marco Polo in connexion with the Province of Kueichow. $\dagger$ Laufer suggests that these are identical with the Yü lin dogs mentioned by the Chinese as being produced in Yü lin chou of Kuanghsi Province, extremely high and large, with drooping ears, and tail different from that of the common dog.t There does not, however, appear to be any good ground for this suggestion.

Marco Polo refers to several kinds of dogs in Tibet. $\mathrm{He}$ speaks of the large and fine dogs, which are of great service in catching the musk-beasts (Book II, Chap. 45). In Chap. 46 he says : "These people of Tebet are an illconditioned race. They have mastiff dogs as big as donkeys, which are capital at seizing wild beasts (and in particular the wild oxen which are called Beyamini, very large and fierce animals). They have also sundry other kinds of sporting dogs and excellent lanner falcons (and sakers) swift in flight,

\footnotetext{
" "The World's History," vol, ii, p. 3 .

† " T'u shu chi ch'eng," vol. dxciii, p. 5 .

f "Pottery of the Han Dynasty," Laufer, p. 265.
} 


\section{DOGS OF CHINA AND JAPAN}

and well trained, which are got in the mountains of the country." *

In the Province of Yunnan the musk and barking-deer, which are small beasts of $40-50 \mathrm{lbs}$. in maximum weight, are hunted with chow dogs of somewhat larger size and weight. Both deer inhabit mountain forests where thin undergrowth and plenty of rocks obtain. They feed upon grass, and in the case of the musk-deer upon moss and lichen. They are very active and sure-footed, traversing rocks and precipitous ground with great agility. It is unlikely that the Tibetans have ever used dogs of mastiff size for hunting these deer. The wild yak, on the other hand, is known to inhabit the open slopes of Tibet, and the use of a large heavy dog in its capture is natural. $\dagger$ Yule notes, "Mr. Cooper at Ta-ts'ien lu, mentions a pack of dogs of another breed (than the large Tibetan dog), tan and black, 'fine animals of the size of setters.' "'

The German suggestion, based on Marco Polo's account, that in his time mastiffs were exported in great numbers from Tibet to China, cannot be correct. He certainly does mention that there were vast numbers of " mastiffs" $t$ at the court of the Great Khan, but the word mastiff or masty was one having a broader signification in those days than in these of shows and careful definition of points. The

"W. Yule, "The Book of Ser Marco Polo," third edition by H. Cordier, London, 1903, vol. ii, p. 52 .

$\dagger$ In the Mongol text of the "Yuan ch'ao pi shi " (Pallad. Trans. 148) in one case, the valour and fierceness of the Mongols are compared with those qualities in the dogs of Tubot. The Chinese translator (fourteenth century) renders " dogs of Tubot" by dogs of "Si fan." Bretschneider, "Mediaval Researches from E. Asiatic Sources:" p. 23, vol. ii.

I Mastiff. "Murray's Dictionary," vol. vi, p. 220, states that the word is more or less confused with old French mestif, mongrel. The form mastin occurs only in Caxton's translations from French: cf. Matin. The word occurs first in 1330 as mastif. 1601. Holland, "Pliny," i, 218: "The Colophonians and Castabaleans maintained certain squadrons of mastiue dogs for their war service." The forms masty, mastie also occur.

80 


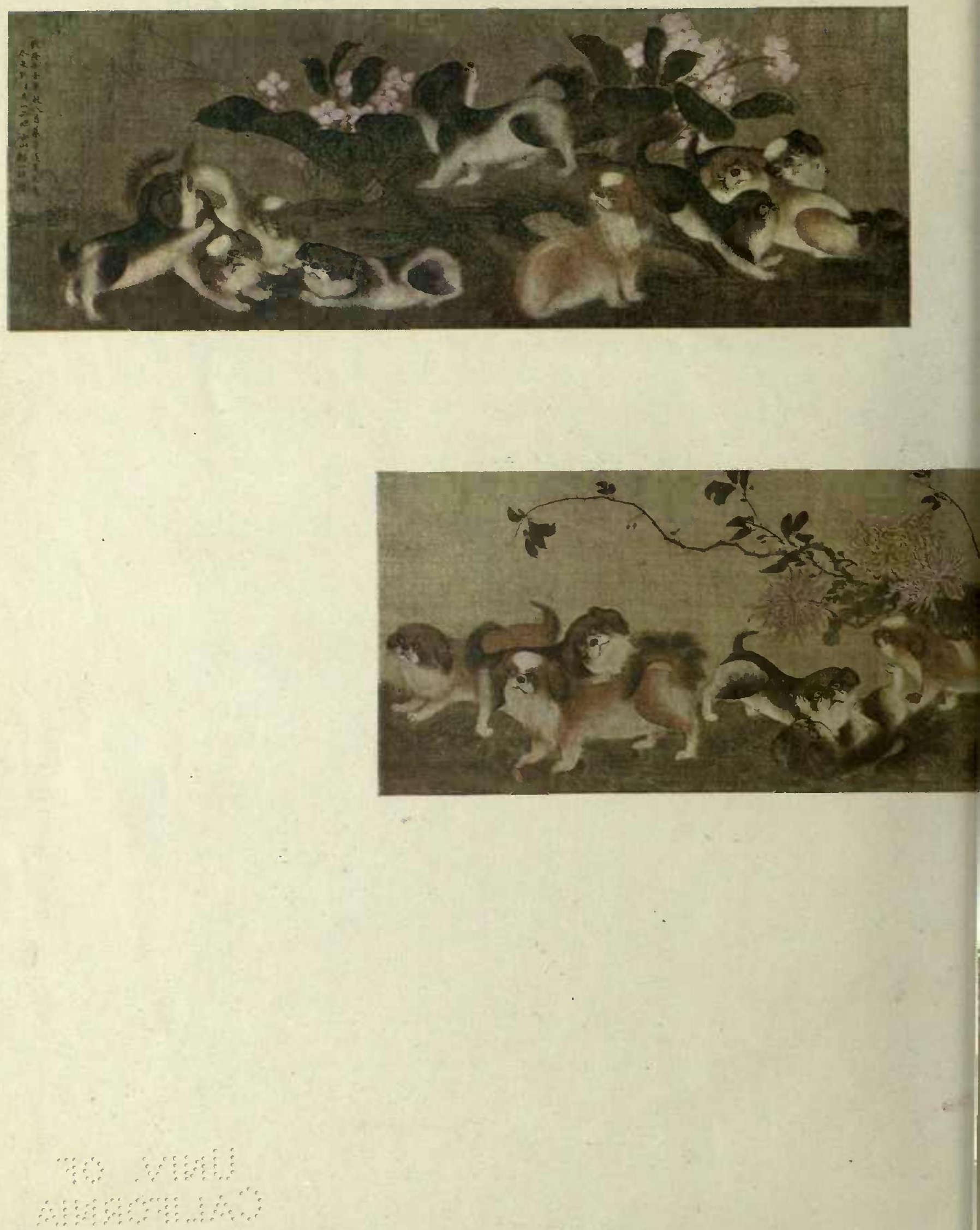

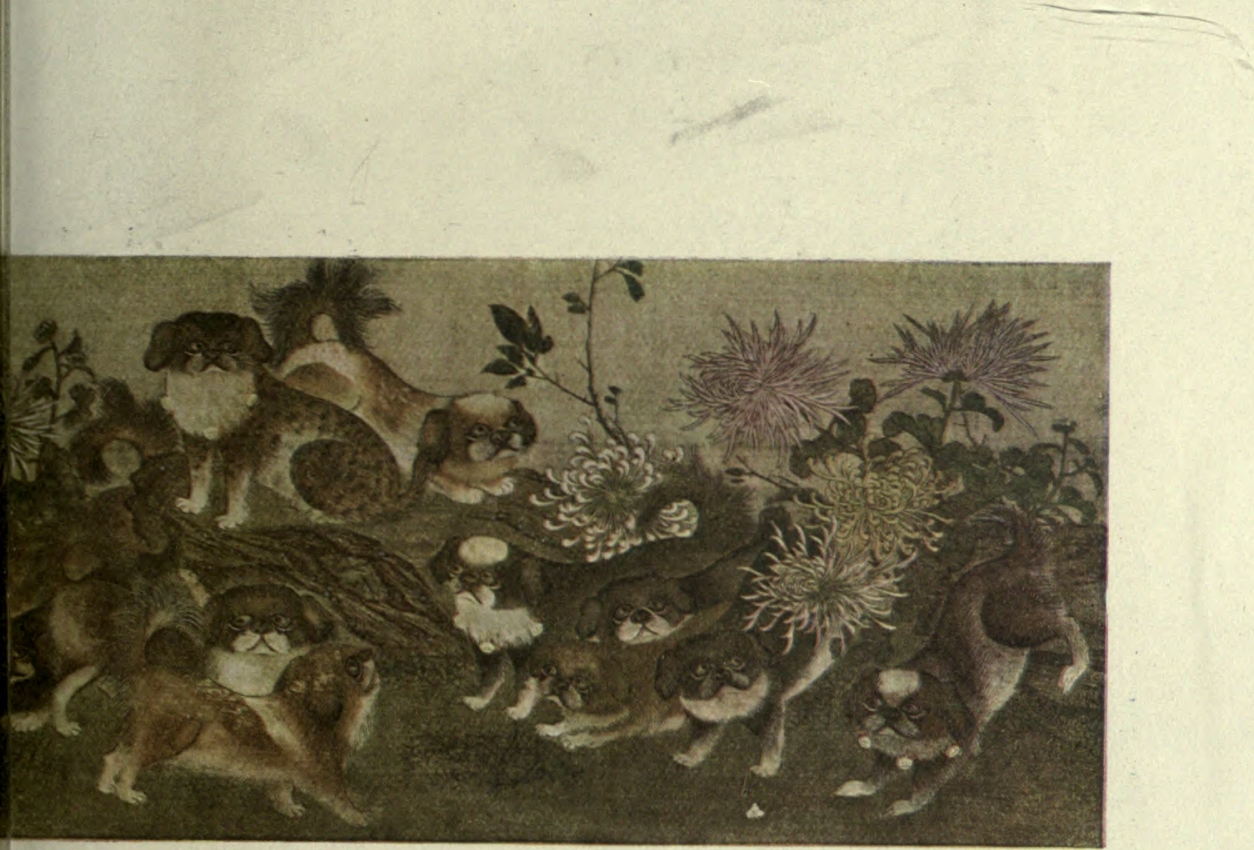


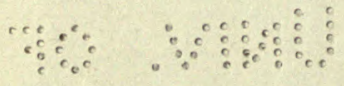

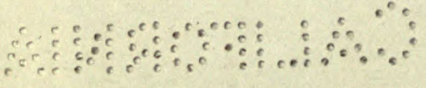




\section{SPORTING AND GUARD DOGS}

Tibetan mastiff, too, has proved itself difficult to acclimatize in certain foreign countries, and is unable to bear the heat of summer in North China. It appears likely that a foreign mastiff race, possibly Mongol, was originally imported into Tibet, and at that altitude was developed into a breed of size and weight suitable for its uses. Research in Tibet itself can alone furnish sound evidence upon the subject. Whether the Tibetans have bred a dog as large as possible with a view to securing some beast analogous to the dog-lion of their scriptures is a matter which may reward inquiry. Buddha was first preached in Tibet about A.D. 632. The Chinese remarked of the early Tibetans that they were accustomed to sacrifice "sheep, dogs, and monkeys." * This race of dogs is known to be widely distributed throughout Tibet. According to Rockhill, $\uparrow$ mastiffs are rare in Eastern Tibet. Pratt states that the best specimens round Tatsienlu come from the Deggi district. Rockhill figures a mastiff which he describes as of Punaka stock.f Ramsay $\S$ says that pure mastiffs are procurable only in Lhasa, very handsome and costly to purchase. $\|$

During the seventeenth century Tibetan mastiffs were not well known to the potentates of the East, and could not have been exported to them, for they, and especially the Shah of Persia, prized exceedingly such mastiffs as they could procure from England through the East India Company.

In $\mathrm{I}^{6} \mathrm{I}_{4}$ the Company's representatives at the Court of the King of "Ajmere" wrote that all the dogs sent by King

* Rockhill, "Life of Buddha," p. 204.

$\dagger$ Fournal R. Asiatic Soc., 1891, pp. 244 et seq.

$f$ "Explorations in Mongolia and Thibet," Rockhill.

\$ "Western Thibet, Lahore," r 89o, p. 33 .

II Compare in Nain Sing's description of his visit to the Thok Jalung gold mines : "At the door of the tent was tied one of those gigantic black Lhasa dogs, of a breed which Nain Sing at once recognized by his deep jowl and white chest-mark." "Tibet the Mysterious," by Sir Thomas Holdich, p. 241. 


\section{DOGS OF CHINA AND JAPAN}

James to the King died on the voyage except one young mastiff which was caused to fight with a leopard and killed it, and also with a bear, which some dogs sent by the King of Persia would not touch, and so " disgraced the Persian dogs, whereby the King was exceedingly pleased." "Two or three mastiffs, a couple of Irish greyhounds, and a couple of well-fed water-spaniels would give him great content."

In 1616 Sir John Roe, the Company's representative at the Court of the Great Mogul, wrote that of the Company's presents the dogs only were well liked. The next year the Company's factor wrote, "From the Persian Court and army near the confines of the Turk, twenty-five days from Ispahan," that among a list of " necessaries " desired by the next fleet were "a suit of armour, two young and fierce mastiffs, and, above all, as many little dogs, both smooth and roughhaired, as can be sent. His women, it seems, do aim at this commodity." On the next day an additional list of toys required by the Persian monarch was sent: "Some choice fighting-cocks and hens, turkey cocks and hens, a dog and a bitch that draw dry foot-these with the little women's curs he chiefly desires of anything you can send him." Four years later, however, the factor at Ispahan states that "Their present of dogs is almost come to nothing. Twig, Swan, and one of the beagles grew mad, whereof they died, albeit Fras. Mason hath taken great pains with them." The Persian demand for British dogs continued, however, for we find the factor at the Persian Court writing: "The king demands coats of mail, mastiffs, water and land-spaniels, Irish greyhounds, and the smallest lap-dogs to be found, well-tempered knives, some of the finest and choicest sorts of China, drinking glasses, and a kind of blue stone whereof they make powder for eyes."

Mastiffs continued to be exported, for in 1625 we find in 82 


\section{SPORTING AND GUARD DOGS}

the minutes of the Court of the East India Company a complaint that the principal mastiffs which were to have been sent abroad as presents were seized by the master of the Bear Garden for the King. It was, perhaps, in retaliation for such complaints that at about the same time dispatch of four mastiffs on one of the Company's ships was vetoed by the King on account of overcrowding.

In 1623 the Company's factors at Batavia remark: "Broad cloth and fine perpetuanos of good and lively colours would yearly vend in these parts, also four or five mastiffs of a fair and stout kind." *

The Tibetan mastiff was first figured in Mr. Bryan Hodgson's " Drawings of Népalese Animals." For the protection of their encampments against wolves, bands of robbers and petty thieves, for the herding of their sheep, yaks, and horses in a country whose climate is arctic in winter, the possession of a race of exceptionally powerful and shaggy dogs is a necessity to the Tibetan. The breed has been known to modern Europe since 1774, when Bogle, who was sent by Warren Hastings as his deputy to visit the Teshu Lama, mentioned the dogs as being of the shepherd breed, "the same kind with those called Nepal dogs, large size, often shagged like a lion, and extremely fierce." Bogle also refers to greyhounds and says, " The Pyn Cushos keep a parcel of all kinds of dogs at Rinjaitzay." $\mathrm{He}$ also refers to a "wolf chained at the foot of the stair." + Bower writes: "We bought a Tibetan sheep-dog here (at Pobrang), to guard the camp, for four rupees. These dogs are something like big, powerfully built collies, and are excellent as watch-dogs, but one never gets fond of them, as they possess nothing of the nobleness of character that European dogs have, and are

* "Calendar of State Papers, East Indies," $15^{13-1625 .}$

† "Tibet," Bogle and Manning, Markham, pp. 68 and 116. 


\section{DOGS OF CHINA AND JAPAN}

generally of a suspicious and cowardly nature." * Bonvalot mentions " two splendid black dogs with red paws, enormous beasts with heads like bears." He also describes the Tibetan hunting-dogs. "Now and again we meet with hunters carrying matchlocks, forks, and lances, with powerful dogs in leash, long-haired like our shepherds' dogs, and with broad heads shaped like that of a bear. Many of these dogs are black, with reddish-brown spots, this latter being generally the colour of their chests and paws as it is that of the hares to the south of the higher tablelands. $t$.

It is likely that travellers have been mistaken to a considerable degree in describing the Tibetan dogs as of enormous size. They are large and powerful, but the appearance of vast size is, no doubt, largely due to their very thick and long coat. The size of the black-tongued chow dogs used in hunting deer in Yunnan Province is very deceptive, as is immediately apparent when they become thoroughly wetted. These dogs, too, are of a suspicious nature, surly and hostile to the white man. They are not, however, cowardly in the chase. Travellers in Thibet cite cases of considerable courage on the part of these dogs such as one in which a dog attacked a wolf without support of any kind.

In $\mathrm{r} 867$, Dr. W. Lockhart wrote that from Mongolia " a noble black dog, as large as a full-sized Newfoundland, is brought to Peking. He is used as a sheep-dog." $\ddagger$ His function, however, was rather protection than that of the English sheep-dog, for, as Dr. Caius remarks : "It is not in Englande, as it is in France, as it is in Flanders, as it is in Syria, as it is in Tartaria, where the sheepe follow the shepherd." §

" "Across Tibet," Bower, 1894, p. 16.

† "Across Tibet," G. Bonvalot, Pitman's translation, vol. ii, p. 96. 84

† Proc. Zool. Soc., 1867. § Abraham Fleming's translation, 1576. 


\section{SPORTING AND GUARD DOGS}

Very few specimens have reached Europe or have ever been seen by foreigners, consequently, attempts at accurate description of the breed do not seem justified. A pair of dogs of the breed, including the Prince of Wales's " Siring," figured in Dalziel's "British Dogs," * was exhibited at the Alexandra Palace Show in 1875 .

The race is represented throughout Mongolia by species no doubt closely allied, which, in size and ferocity, approach those of the native of Tibet. The partiality of Chinese leopards for canine diet is crystallized in an old Chinese saying, "The dog is the wine of the leopard." In Mongolia, however, the tables are turned, and the natives attribute comparative freedom from leopards to the ferocity of their dogs. So fierce and dangerous are these, that the Mongolians are obliged by their laws to come out and protect travellers entering their encampments. Until they receive this protection, horsemen remain in the saddle; foot-travellers keep the dogs at bay as best they can with sticks.

The race is similar to the British mastiff, but stronger and more heavily built. The head is longer, the pendent ears larger, the lips deeper, the tail long and brush-like, the coat heavier, and the expression more fierce. The colour is often black or brown, with light muzzle and legs. The race, native of a country whose tablelands average $16,500 \mathrm{ft}$. above sealevel, is difficult to acclimatize in foreign countries, apparently through inability to bear the heat of summer. A pair taken to the alpine climate of Yunnanfu in I9I I succumbed within four months. The Tibetan priests have occasionally succeeded in rearing the breed in Peking, keeping the dogs in a cellar during the hot weather. Sarat Chandra Das $\uparrow$ considered that the race was found in a wild state in the country. He speaks of a collection of stuffed animals in one of the mon-

$$
\text { - Vol. ii, p. } 185 \text {. † "Narrative of a Journey to Lhasa," } 1885 .
$$




\section{DOGS OF CHINA AND JAPAN}

asteries, including specimens of "the snow leopard, wild sheep, goat (called Dong), stag, and wild mastiff."

Das mentions that the dog was prized as a most useful animal by all classes in Tibet. The killing of dogs was severely punished. "If a dog is killed by blows on his hinder part it is to be taken for granted that it is to some extent blameless, as it must have been running for its life and being chastised or pursued. In such instances the compensation for a good house-dog is 37 rupees, for a dokpyi or mastiff 25 rupees, and for a common dog 12 rupees. If a dog is killed by blows on its head the offence is considered very light. In such cases the dog is considered to have been the offender and to have been killed in self-defence, so that there is no punishment." Old English law had less sympathy for the dog and his master. "If any person have a dog liable to hurt people and he hath notice thereof and if, after, he doth any hurt to cattle or otherwise, it is a misdemeanour of the highest kinds; and if he doth bodily hurt to any of His Majesty's liege subjects so that death ensue, it is Manslaughter or Murder in the owner of the said dog, after notice, according to the circumstances." *

The importance of the house-dog to the Tibetans is shown by a further remark by Das: "When a thief steals a lock or key or a watch-dog from a house his offence will be tantamount to stealing the contents of the house or store to which these belonged. The stealing of a lock or key or a dog is the same as robbing the treasure which they guard."

These customs may be connected with the ancient religious beliefs found in the Zend Avesta: "Whosoever shall smite either a shepherd's dog, or a house-dog, or a vagrant dog or a hunting-dog, his soul when passing to the other world, shall fly amid louder howling and fiercer pursuing than does the

* Notes and Queries, 7 th series, viii, p. 234 . 


\section{SPORTING AND GUARD DOGS}

sheep when the wolf rushes upon it in the lofty forest. . . . If a man shall smite a shepherd's dog so that it becomes unfit for work, if he shall cut off its ear or its paw, and thereupon a thief or wolf break in and carry away sheep from the fold, without the dog giving any warning, the man shall pay for the lost sheep, and he shall pay for the wound of the dog as for wilful wounding. If a man shall smite a house-dog so that it becomes unfit for work ... and thereupon a thief or a wolf break in ... the man shall pay for the lost goods, and he shall pay for the wound of the dog." *

In connexion with the death of the Grand Lama, Das states that at Tashi-Lumpo there were found " large packs of hounds and mastiffs which the Grand Lama had kept for sporting purposes, though the sacerdotal function precluded him from shooting animals."

In the course of his remarks on the funeral ceremonies of the Tibetans, Das comments on the participation of dogs with vultures in the gruesome rites as to disposal of the dead, practised throughout Lamaist Mongolia to this day.

Sir Thomas Holdich mentions the "savage corpse-eating dogs which infest the purlieus of Lhasa, and says that "a solitary wayfarer on foot runs no little risk from the number of savage dogs which prowl around the city wall feeding on offal and human corpses." $†$ Manning's description of Lhasa is

" "Sacred Books of the East," vol. iv, p. 154.

+ "Tibet the Mysterious," by Sir Thomas Holdich, p. 258. "The giving of the dead to dogs and vultures was a Persian practice, and was perhaps a custom of great antiquity among the Aryans generally." "The Rise of Man," by C. R. Conder.

"According to Strabo the manners of the Bactrians differed in little from those of the Scythians in their vicinity. The old men, Onesicritus asserted, were abandoned whilst yet living, to the dogs, which were thence called ' buriers of the dead.' . . . In the present ritual of the Parsis the dog plays a very prominent part. Amongst other various particulars relating to the animal, it is enjoined that dogs of different colours should be made to see a dead body on its way to be exposed, either thrice or six or nine times, that they may drive away the evil spirit, the Daruj Nesosh, who comes 


\section{DOGS OF CHINA AND JAPAN}

little more pleasing. "There is nothing striking, nothing pleasing in its appearance. The inhabitants are begrimed with dirt and smut. The avenues are full of dogs, some growlling and gnawing bits of hide which lie about in profusion and emit a charnel-house smell ; others limping and looking livid ; others ulcerated ; others starved and dying and pecked at by ravens, some dead and preyed upon."

Das deals with the treatment of hydrophobia in Tibet. His remarks are quoted as an interesting comment on the superstitious medical practice which is, no doubt, current in Tibet at the present day, and is only now losing ground in China where in Yunnan Province a teaspoonful of tin-filings and a similar quantity of copper-filings mixed daily in a dog's food are considered as a sovereign protection against rabiesa custom no more irrational than the English use of a hair of the dog that bit, or the Arab appeal to sympathetic magic in seeking to cure hydrophobia by use of the head of a dog burnt, reduced to ashes, and kneaded with vinegar.

" The poison of a white rabid dog with red, flushed nose affects at all times; that of a red or brown dog is more dangerous when one is bitten at midday, midnight, or sunrise ; that of a parti-coloured dog, between 8 a.m. to I p.m.; of spotted ones at 9 p.m. or at twilight; of iron-grey ones at night or dawn; and that of a yellow rabid dog is sure to be fatal when one is bitten at dusk or 9 a.m. The baneful effects of this dangerous malady break out seven days after the bite of a white dog, one month after that of a black dog, 16 days after that of a parti-coloured, 26 days after that of an ash-grey, from one month to $7 \frac{1}{2}$ months in the case of a red,

from the North and settles upon the carcase in the shape of a fly." "Antiquities of Afghanistan," p. 163, Wilson.

"When either the yellow dog with fair eyes, or the white dog with yellow ears, is brought there then the Drug Nasu flies away to the regions of the North." Zend Avesta, Fargard, viii, 3 .

88 


\section{SPORTING AND GUARD DOGS}

3 to 7 months in that of a blackish-yellow, one year and a half-month in that of a spotted, and a year and 8 months after the bite of a bluish-black or tiger-coloured rabid dog. It is difficult to cure the disease when caused by a bite of the last kind of dogs at 7 p.m. or dusk, or by that of a black dog at dawn; but if a blue dog bites at midday, a red one at midnight, a spotted one at dawn, or a white one early in the morning, the patient can easily be cured." 


\section{CHAPTER V \\ THE CHINESE LION}

The lion not indigenous : Popularity due to the introduction of Buddhism from India: The lion in captivity in China : Origin of lion-worship : The lion in Indian Buddhism : The lion in Foism : The lion in Lamaism : Description of the Lamaist lion : The spirit-lion and the lion-dog : Buddhist lion-stories: Chinese artistic idea of the lion : The lion in heraldry.

7 HE history and attributes of Tibetan, Pekingese and Japanese toy-dogs are so closely interwoven with

1 those of the Buddhist lion that a digression is necessary in order to define their relationships.

At the dawn of historical time the tiger held pride of place in popular imagination both in China and Japan. It was the king of land animals, , and though deposed in China, continues to be the royal quadruped in Corea. Early representations in pottery bore the character wang- " king "-fancifully seen by the Chinese in the tiger's forehead stripes. Absence of references in the old writings indicates that the lion was altogether unknown in China up to the time of its introduction from abroad. The lion was unknown to Feng Shui, China's ancient natural science, and though the lion is one of the twelve signs of the Chinese ecliptic, in some degree analogous to the signs of the zodiac, as indicating the twelve places in which the sun and moon came into conjunction, the Chinese have no constellation Leo. Why then, it may be asked, have they adopted a foreign importation as lord of beasts, as the commonest motif in their art, and as the centre

* Bushell, "Chinese Art," vol. 2, p. 9. 


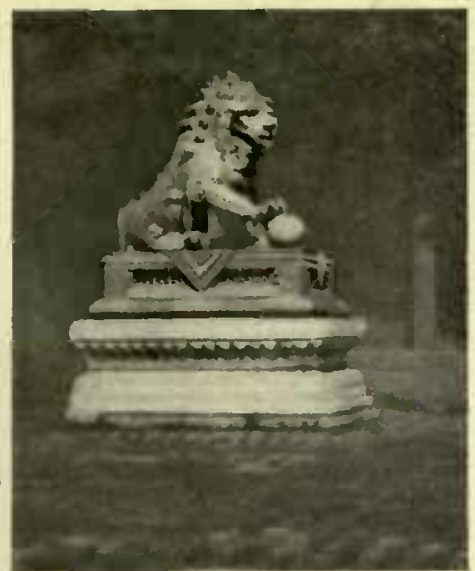

LAMAIST LION (MALE). BRONZE. YUNG HO RUNG (LAMA TEMPLE, PEKING), CH'IEN LUNG PERIOD. Inscription " $\mathrm{T}_{\mathrm{a}}$ Ching Ch'ien Lung Nien

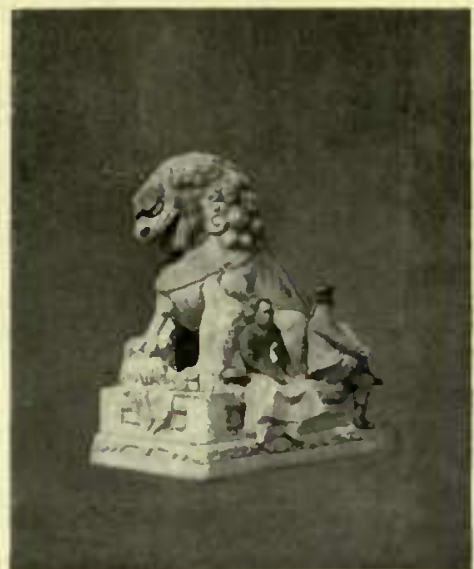

STONE LAMAIST LION, TIEN AN MEN. IMPERIAL PALACE, PEKING

Tsao." Exact date unknown

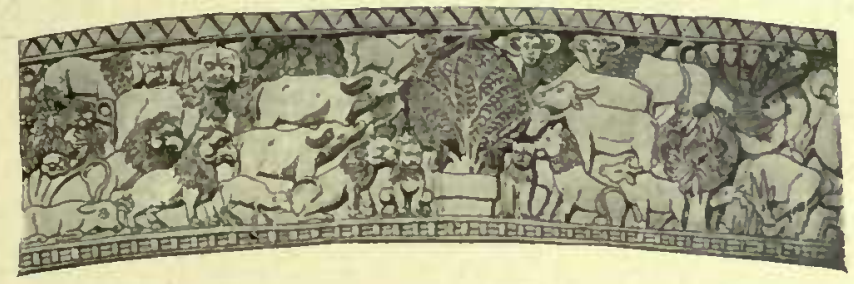

THE ANIMAL WORLD REVERENCING A SACRED TREE. RELIEF FROM EAST GATE, SANCHI (INDIA), ABOUT T40 B.C.

(Gibson, "Buddhist Art in India")
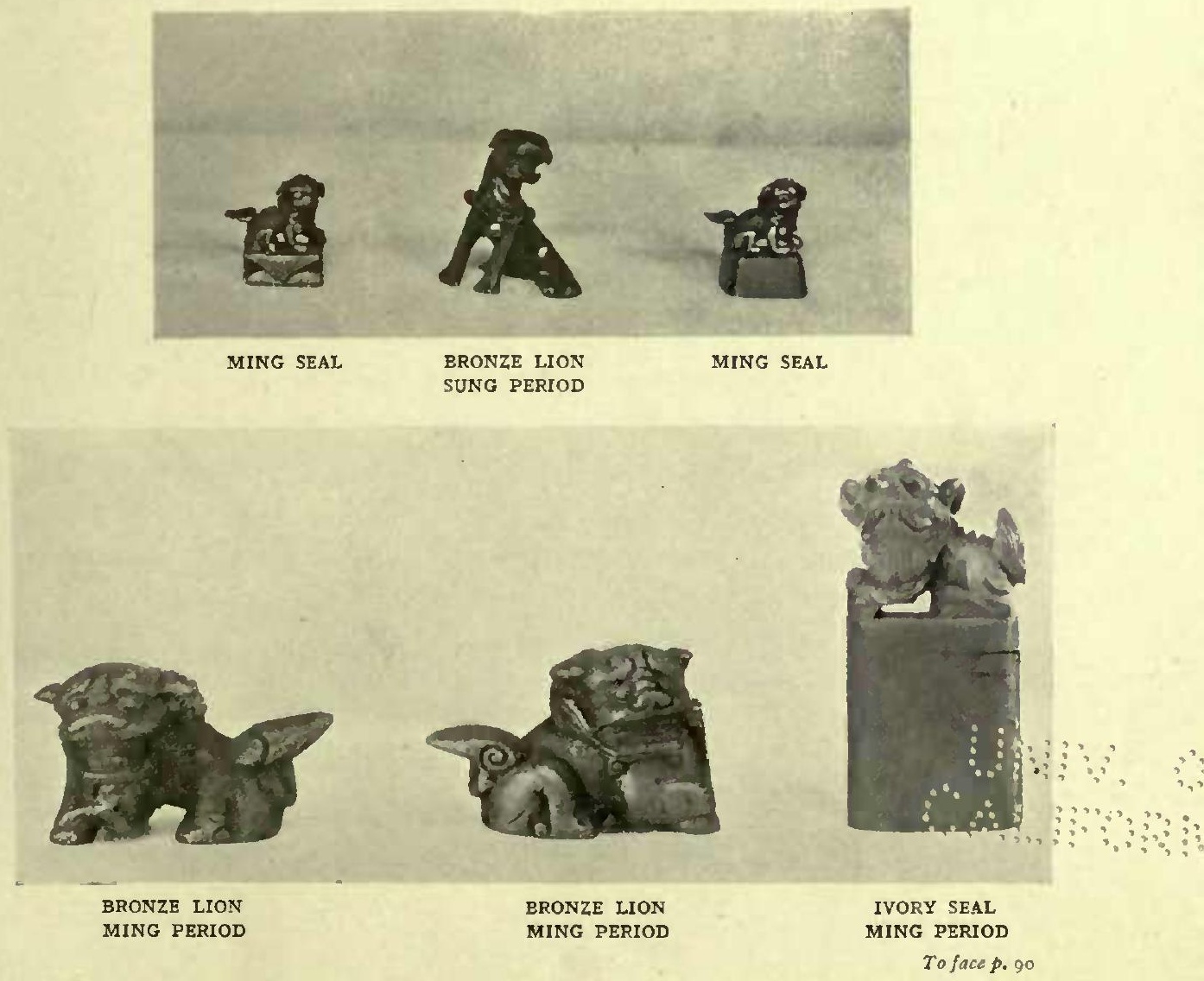


\section{THE CHINESE LION}

of more symbolism and legend than any other beast in any country? The answer is found in the close association of the lion with Buddhism, which was a foreign religion. Buddhism reached China directly from India, and indirectly, as Lamaism, through Tibet.

Lions are still found in India in the State of Kathiawar.* There is little doubt, however, that the lion has never existed in the wild state in China. The few records dealing with it in captivity may be dismissed before entering upon more abstruse subjects such as the lion in Buddhism and Lamaism, its symbolism and relation to the lion-dog.

The Chinese Emperors of the Han Dynasty (202 B.c.) were probably the first to become interested in lions. Chang Ch'ien, one of their envoys, returned from his Western travels in the year 126 B.C. and informed the Chinese Emperor of the wonders of India and of Buddhism.

Intercourse between China, India, Parthia and other Buddhist countries became frequent from 126 B.C. onwards, through the Sinkiang trade route passing north of Tibet.

The first recorded importation of lions occurred in A.D. 87. They came from An-hsi, Parthia. Their close association with Buddhism accounts for the fact that from this time onwards they were frequently imported as tribute or presents from numerous Eastern states and also from Europe, until the successive conquests of Islam, the declared enemy of all unclean beasts, interrupted communications.

Chinese artists have always been in difficulties in their representations of the lion. Few of them could secure access to living models of the king of beasts. Consequently they had recourse either to the conventionalized figures, pure

" "Lions were numerous in the northern parts of the United Provinces as late as the time of Bishop Heber in 1824 , but are now found only in Kathiawar. The last specimen recorded in Northern India was killed in the Gwalior State in 1872." "The Oxford History of India," p. 153. 


\section{DOGS OF CHINA AND JAPAN}

Buddhist and, secondarily, Lamaist, for their sacred representations, or for lay pictures to the fanciful descriptions such as that of the scholiasts of the Han Annals. "The lion resembles a tiger, and is yellow; it has side-whiskers and the soft hair at the end of its tail is of the size of a grainmeasure (tou)." "In fact, the Chinese have never had a correct conception of the lion, nor have their artists ever drawn a natural sketch of a lion from life, but merely copied the fanciful conventionalized types of lions introduced into China from India with Buddhism." *

When the Chinese pilgrim Sung Yun (A.D. $5^{18}$ ) saw two young lions at the Court of Gaudhara, he wondered that the pictures of these animals, common in China, were not at all good likenesses." $\dagger$

Lions continued to be sent to succeeding Chinese Emperors up to the time of K'ang Hsi. The Portuguese possessed lions, doubtless for the purposes of propaganda, at Macao.

The following note is recorded as late as the sixteenth century: "Nothing fetched so great a price among the Chinese as a lion, for this beast does not occur in those countries. They look upon it with intense admiration, and give any price for it." $\ddagger$

Old paintings of tribute-bearing embassies to the Chinese Emperors include lions gambolling with a multicoloured ball.

Kublai Khan followed the example of Alexander the Great in keeping lions in his palace. After State banquets the wild beasts were paraded as a diversion for the Imperial guests. "Then came mummers leading lions which they caused to salute the lord with a reverence," says Friar Odoric.

" "Chinese Pottery of the Han Dynasty," Laufer, pp. 238-9.

† Z. Yule, "Marco Polo," third edition, vol. i, p. 399.

I "Cathay and the Way Thither," vol. ii, p. 298. 


\section{THE CHINESE LION}

There existed in Peking in Kublai Khan's time small dogs which so resembled lions that a Chinese historian in describing the Imperial menagerie remarks that the lions are of the same colour and astonishingly like the golden-coated nimble dogs which are commonly bred by the people in their homes.*

The following description of a fourteenth-century Imperial hunt $\dagger$ seems worth quotation, though Marco Polo always mistakes tigers for lions. "When the Great Khan (Magnus Canis) goes a hunting 'tis thus ordered. At some twenty days' journey from Cambalech (Peking) there is a fine forest of eight days' journey in compass ; and in it are such multitudes and varieties of animals as are truly wonderful. All round this forest there be keepers posted on account of the Khan, to take diligent charge thereof; and every third or fourth year he goeth with his people to this forest. On such occasions they first surround the whole forest with beaters, and let slip the dogs and the hawks trained to this sport, and then, gradually closing in upon the game, they drive it to a certain fine open spot that there is in the middle of the wood. Here there becomes massed together an extraordinary multitude of wild beasts, such as lions, wild oxen, bears, stags, and a great variety of others, and all in a state of the greatest alarm. For there is such a prodigious noise and uproar raised by the birds and the dogs that have been let slip into the wood, that a person cannot hear what his neighbour says ; and all the unfortunate wild beasts quiver with terror at the disturbance. And when they all have been driven together into that open glade, the Great Khan comes up on three elephants and shoots five arrows at the game."

Chinese history relates in detail how two hundred and fifty years later the Emperor Kang Hsi, with the aid of two

- Jih Hsia Chiu Wen K'ao.

† "Cathay and the Way Thither," Yule. 


\section{DOGS OF CHINA AND JAPAN}

hunting lions overcame two bears, one of them weighing 1300 catties, and deposited the skins stretched over wooden dummies in the Yung Ho Kung (Lama temple), where the dummies may still be seen. It may be that these hunting lions were useful rather for the prestige they gave their masters than for the hunting itself. Rameses II and III each possessed a tame lion which accompanied them to battle and attacked the enemy. Budge, however, remarks that they were probably more valued as symbols of the Sun-god than as effective combatants. The Egyptians believed that a god was always incarnate in their king.

Passing now to the religious aspect of the subject it may be suggested that the origin of lion-worship goes back to a time when lions were very plentiful in Northern Africa and in Asia, and perhaps to a period when man's unequal struggle with the King of Beasts was habitually decided in favour of the latter. The lion was worshipped by the Egyptians and was usually associated with the sun-god. Sacred lions were kept at many places throughout Egypt. By the time of the reign of Tiglath-pileser, King of Assyria, 700 B.C., lionworship was probably in its decline in that country, for lion hunting had become the favourite sport of the Assyrian kings, and this ruler boasts, "Under the auspices of Nineb (God of War), my patron, I killed Izo lions in my youthful ardour, in the fulness of my manly might on my own feet ; and 800 lions I killed from my chariot." This humbling of the lion was effected probably in Syria. Lower Egypt was occupied by the Assyrians early in the sixth century B.C., but by its close the Assyrian power had been superseded by that of Babylon, to be overthrown in its turn by Cyrus, King of the Persians, in 539 B.c.

The Persians, previous to the Mohammedan conquest, paid special homage to the lion. It is not possible to define the 94 

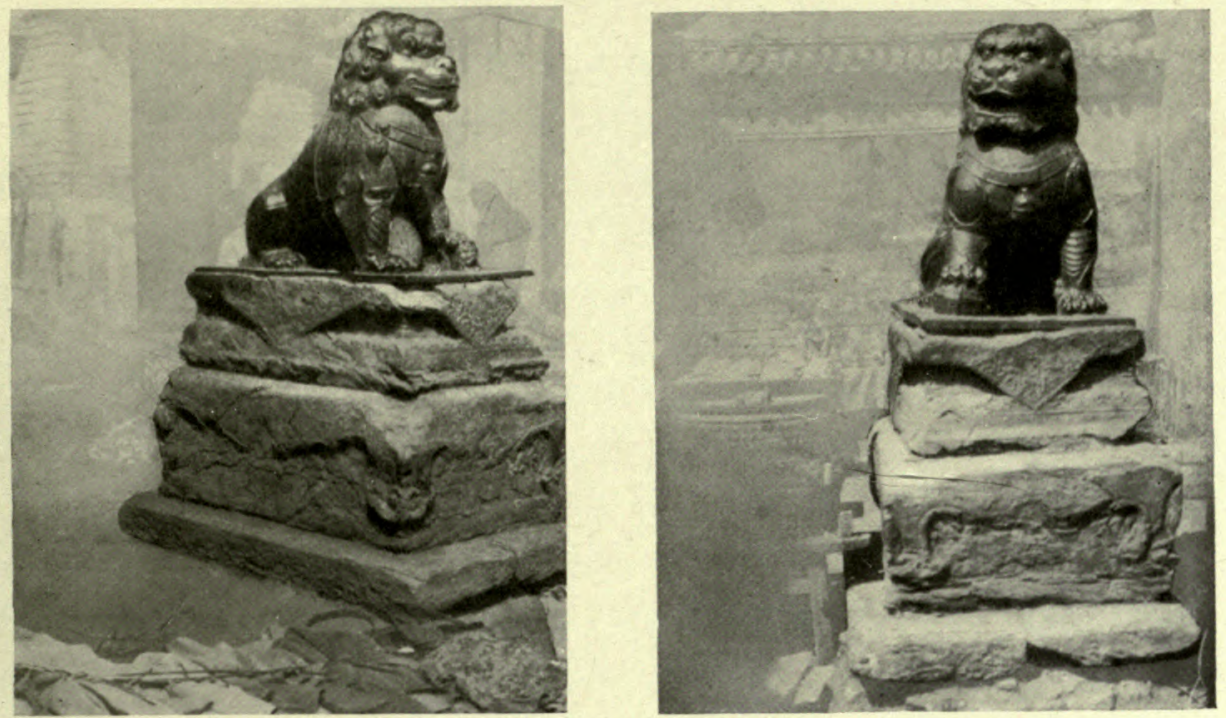

IRON LIONS BEFORE THE TEMPLE OF CHIAO CHUN, GOD OF COOKERY PEKING, I665. K'ANG HSI PERIOD

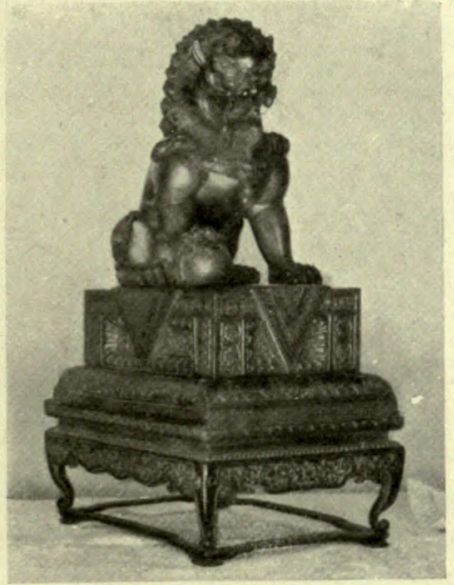

LAMAIST BRONZE LIONS, MODERN

(FROM THE TEMPLE OF A HOUSEHOLD, PEKING)

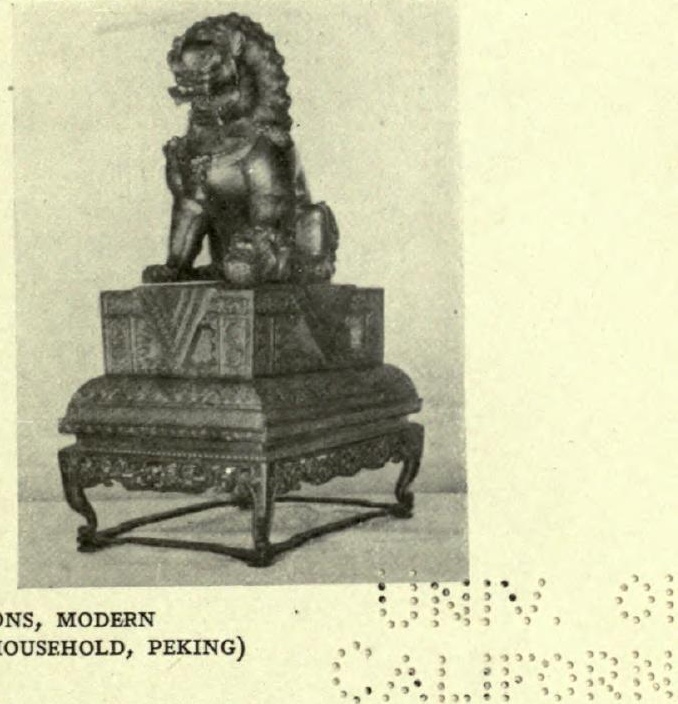

To face p. 94 


\section{THE CHINESE LION}

period at which this veneration gave way to simple curiosity and the interest of the menagerie owner. In the temples of the Persian goddess Anahita the lions were so tame that they caressed visitors to her shrine in the most friendly manner.

In Greece lions were used by the priests of Cybele for exorcising devils, as they are used in North Africa to this day.*

The lion was associated with Buddhism from a very early date, for Asoka, the Buddhist Emperor of India, whose conversion took place 260 B.C., and to whose extreme activity Buddhism owes its world-wide expansion and possibly its very existence, erected many stone and wooden pillars often bearing Buddhist inscriptions and capped by a crouching Buddhist lion. He orders one of the edicts to be chiselled " wheresoever stone pillars exist." This, together with the active Chinese belief in charms and amulets, is very possibly the origin of the innumerable lion-surmounted pillars found throughout China in cemeteries, on the sign-poles of shops, on bridges, and in fact wherever an opportunity for such ornamentation occurs. $\dagger$ The figure of a lion is frequently used as a charm in front of a Chinese door. A similar charm exists in Assyria. "Spin together hair from a dog and hair from a lion and thread three cornelians thereon, bind it on and he shall recover," is a magical prescription against sickness in that country.f The theory of subjection of the lion to Buddha probably existed in Asoka's time. The lion on the famous Lauriya pillar, for instance, was apparently used to exemplify the subjection of the fiercest passions to the gentle influences of Buddhism and possibly to vivify

* Sir A. Pease, "The Book of the Lion."

† For notes on the lion-pillars of Shensi, see Laufer, "Pottery of the Han Dynasty," p. 240.

I "Semitic Magic," R. Campbell Johnson, p. lxiv. 


\section{DOGS OF CHINA AND JAPAN}

Buddhist approval of the setting up of "curative arrangements for beasts " everywhere in India " as far as Ceylon" and to the borders of "Antiochus the Greek King." *

Chinese representations of the Buddhist " true " or sacred lions may be classified as being of two distinct types: the pure Buddhist and the Lamaist. The former is that which came to China with early Indian Buddhism or Foism, possibly before the division of Buddhism into the great Northern and Southern sects after the Council of Jalandhara (A.D. IOO), and certainly before the arrival of Lamaism.

This variety is represented without harness. Its mane is not curled, and there is no orb or cub beneath the paw of male or female. The influence of this Southern Buddhism or Foism was strong in China up to the middle of the seventh century, when Buddhism declined rapidly in Northern India, finally becoming extinct, except in Ceylon, the Chinese "lion country," whose armorial bearings are lions to this day. What Buddhism lost in India, however, it gained in Tibet, whence (dating from the seventh century A.D.) it obtained both religious and political supremacy.

Buddhism did not establish itself firmly among the Chinese until the year A.D. 67, when the Emperor Ming Ti publicly encouraged Buddhist missionaries from India and himself embraced Buddhism.

The practice of placing monuments before doorways in China is recorded as early as the anterior T'ang Dynasty, about 1766-1753 B.C., but the earliest recorded instance found in Chinese literature of the use of stone lions is in the case of the palace of Huo Bin, an important official who died in II7 B.C., soon after Chang Chien's return from the West.

Buddhism flourished exceedingly in China, and became the State religion in the fifth and sixth centuries. Early in * "Asoka," Vincent A. Smith. 


\section{THE CHINESE LION}

the T'ang dynasty (A.D. 6I8-906) the headquarters of the faith was moved from India, in which its power was fast: giving place to Hinduism, to China, which was then a worldpower, and as such was appealed to by many of the countries of Central Asia for defence against the rising power of the Arabs and Mohammed. There is no doubt that representations of the Buddhist lion, as well as of its living original, became very common during the T'ang and Sung Dynastiesthe golden period of Chinese art-though few have come down to us.

Tibet was conquered by Genghis Khan about A.D. 1206, and Kublai Khan was thus brought into contact with Lamaism. He called the Grand Lama to his Court, and, after consulting the representatives of Christianity and several other faiths, he ultimately adopted as his State religion Lamaism, which thus received a mighty accession of strength.*

The Lama priests of Tibet distinguished between " true lions "-the spiritual beasts whose images are found in the Buddhist sacred places-and "dog-lions," the earthly beasts known to the menagerie. They teach that the true lion is a mountain spirit, having powers of instantaneous projection through space, visible or invisible at will, and similarly capable of infinite magnification or reduction of size.

The Lamaist lion was no doubt produced in Tibet before the seventh century A.D. by the grafting upon Buddhism of the sun-worship of Egypt, the nature-worship of the races of the Euphrates Valley, the Christian influence of the Nestorians and superstitions of numerous cults persisting after the break-up of the Babylonian and Assyrian empires. These were all subjected, for their visible representation, to Greek influence, for Greek art was, during the first three centuries

" "L. A. Waddell's " Lamaism." 


\section{DOGS OF CHINA AND JAPAN}

of our era at least, an article of exportation,* and artists and artasters seem to have travelled everywhere in search of employment, adapting the models of their native art to the requirements of the local religion. Laufer remarks, "I have no doubt that the prototype of the figure of the lion on the Han pottery reliefs found its way to China through the same channels as the design of the archer on horseback; i.e. through the medium of Scythian and old Siberian art. The occurrence of the lion on works of Scythian art is very frequent ; and as to Siberia, we have many examples of it on the famous gold plaques of the Eremitage, on which, as in China, the lion is represented, particularly in hunting scenes. The type of the Scythian and Siberian lion is undoubtedly derived from Mycenian and Greek art, and thus the transplanting of it to Chinese soil is historically and logically accounted for."

The Lamaists teach that the "dog-lion" is as inferior to the "true lion" of their religion as is the canine species to the leonine. These species are, however, as will be explained later, closely connected in Buddhist lore, and the commonly found Western fallacy suggesting that Buddhists reverence dogs and that Chinese toy-dogs are held sacred, based no doubt on the likeness between the sacred lion and the Pekingese dog, has found support from the Lamaist association of the lion-dog with the sacred spirit-lion found in Tibetan scripture. Both Tibetans and Chinese have no doubt bred a race of toy-dogs to resemble as closely as possible their respective ideas of the spirit-lion.

The close connexion of Tibetan lore with Egyptian science is commented on by Captain Turner, one of the first Englishmen to enter Tibet, sent by Warren Hastings in an endeavour to open up trade intercourse in 1800 . Turner mentions that * "Buddhist Art in India," Burgess. 


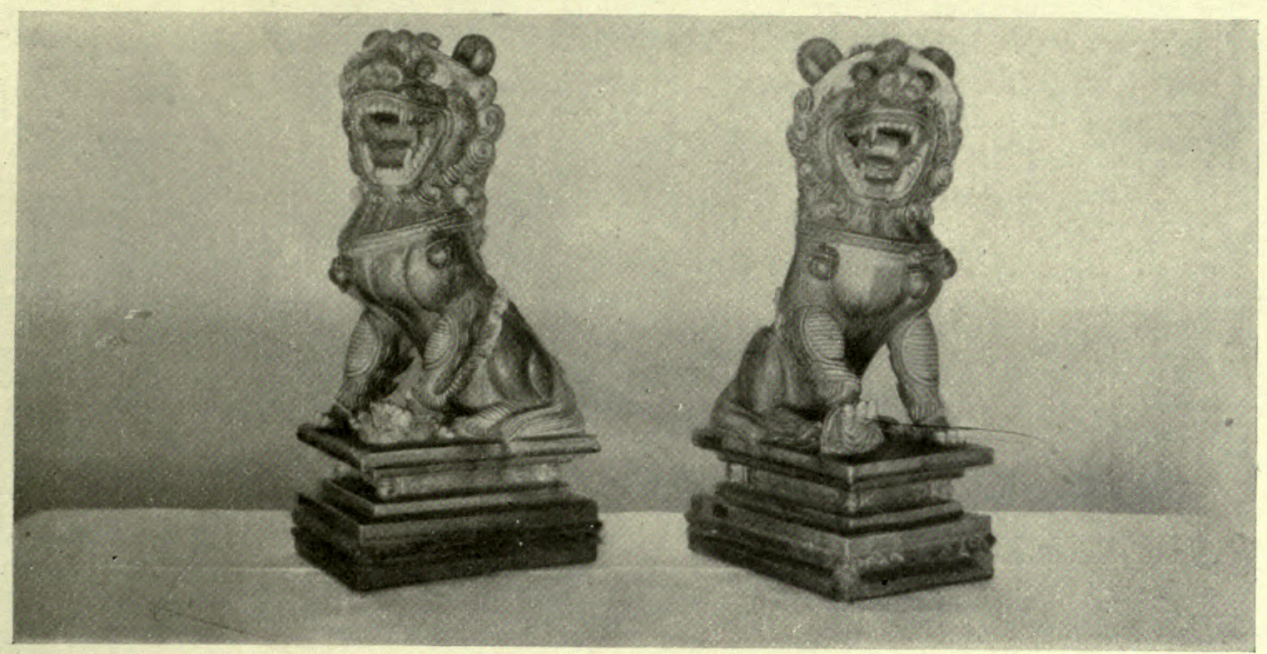

PORCELAIN LIONS. MING PERIOD







\section{THE CHINESE LION}

he received a visit from Soopoon Choomboo, one of the high officials, and remarks, "He was accompanied by the Treasurer; our conversation was extremely miscellaneous. Egypt, in their language eunani, and the lions, singhi,* were favourite topics of conversation with him. Between this country indeed and Tibet there seemed at some time or other to have existed a frequent communication, and Egypt appeared even now to merit respectful mention whenever they named it. From hence perhaps they have derived their veneration for the sovereign of brutes, which they evince by the distinguished place they assign him in their sacred architecture.

" There is no religious edifice but what is adorned with the head of the lion at every angle, having bells pendant from his lower jaw, and the same figure is equally common at every projection of the palace walls. It is certain that no contiguous country can supply an example of the animal existing in it, in a state of nature, at this day. The lake Maunserore was mentioned to me, as having lions on its banks, but this assertion I considered as fabulous, originating possibly in a desire to attach greater dignity to the source of the Ganges and Bermapooter by adding to it one more object of veneration.

"Lions are the natives of a warmer region; the burning sands of Nubia, Ethiopia and Arabia seem to be their proper habitation. But be this as it may, we see the head of the lion held up in Tibet with marks of high distinction and respect, though we can trace no certain clue to discover by what means he obtained the honour." $\dagger$

* Laufer says that the Tibetan word for "lion" (seng-ge) was borrowed from the Sanskrit simha. Giles translates suan (suan-i is a lion-like animal occurring in Chinese literature before the lion was known in China) as " a lion from Tibet." Research may show that suan-ni and seng-ge have a common origin.

$\dagger$ "An account of an Embassy to the Court of the Teshoo Lama in Tibet," by Captain Sam. Turner, 1800 . 


\section{DOGS OF CHINA AND JAPAN}

In sharp opposition to Foism, which favoured simplicity, the Tibetans have done their utmost to centre upon the lion, which in Lamaism has become the most picturesque of its minor retainers, the maximum of fable and superstition. The Lamaists appear to have desired to conjure up a visible symbol of the power of their faith in order to impress its realism upon a people which, being isolated from the rest of the world, is uneducated, credulous and highly superstitious.

The best representations of the Tibetan Buddhist lion which have come down to us are those of bronze or stone which stood originally in the southern doorways of the Imperial or Princes' palaces or of the Lama temple in Peking. They represent a short-bodied beast, well knit and of extraordinary strength, with massive legs and pads, head somewhat rectangular, sometimes ornamented with stars, nose short, the whole aspect being canine rather than feline. The face, with broad, thick pug-nose and gaping mouth, shows the influence of early mediæval art exemplified in the ogres and gargoyles of Western religion. The mane is extraordinarily bushy, wig-like, in fact, and made up of curls as of conch-shells, with compressed volutes both right and left-handed. A straight whisker or beard split in the middle hangs from the lower lip. There are fringes behind the fore-arms and heels of the hind legs. The tail is short, with a bushy tip. The beast is harnessed with a broad and very open collar studded with brass openwork. From it hang pointed tassels or perhaps a bell attached by a ring to a ram-horned lion-head with flaring side-mane, at the apex of the somewhat pointed chest. There emerges from behind the mane a double tape-like leading-string, shortened by knots and loops, resting on the back and terminating at the insertion of the tail. These animals are, of course, recognized by all Chinese as lions distinct from all the numerous lionI00 


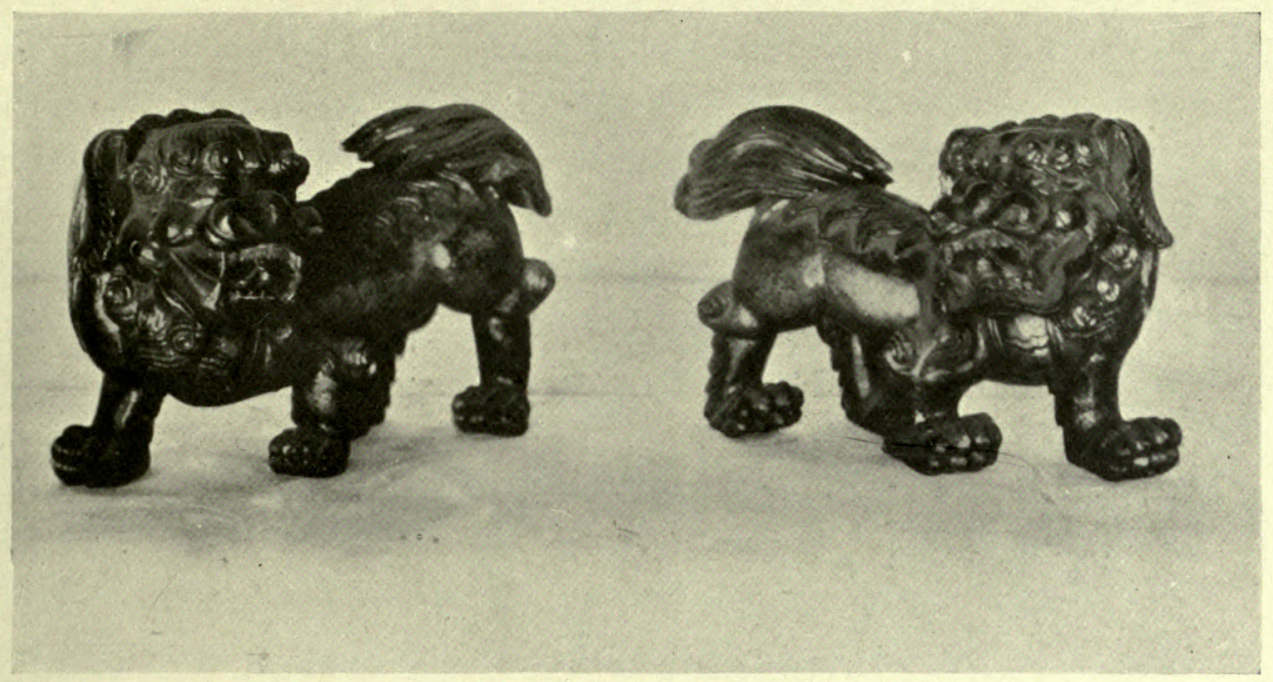

LIONS IN LACQUERED WOOD, SHOP-FRONT, PEKING

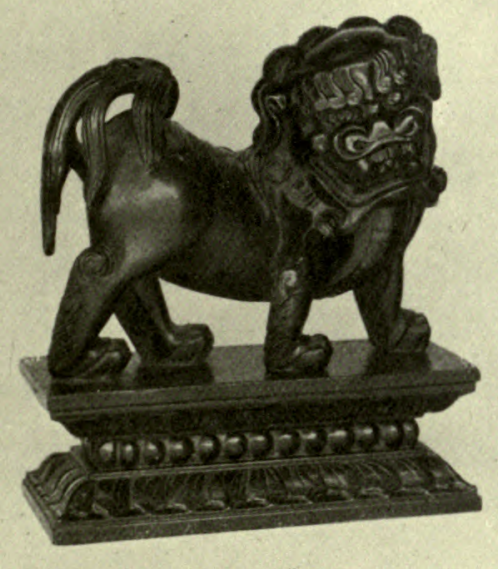

LIONS IN BLACKWOOD, PEKING

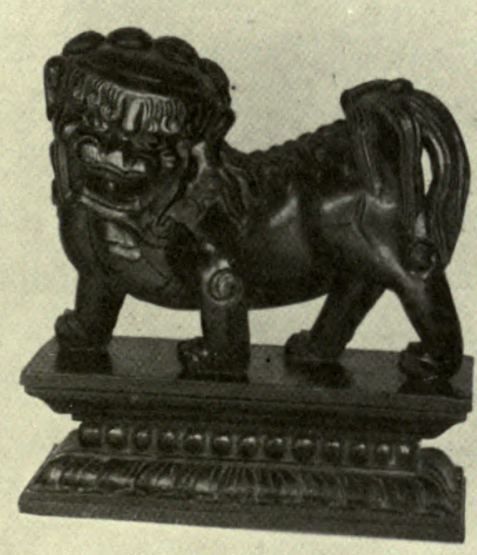





\section{THE CHINESE LION}

like beasts included in Oriental mythology. Figures of the kind are invariably in pairs, one of which, the male, has its right pad set upon a ball of coarse embroidered pattern, while the left pad of the female rests upon a lion-cub holding the beak-like claws of the lioness in its mouth. The ethereal nature of the beasts is shown by flame-like emanations often represented as playing over their bodies. The figures are set each upon a richly embroidered cloth called the "chingti'erh " or "Bible-cloth," of a design found in similar Assyrian monuments, which is used in Tibet for covering the temple tables where the sacred books are laid. This cloth overlies a low pedestal of framework design, which is also richly ornamented and similar to the tables, being built low to serve as a seat on which the Tibetan priest sits crossedlegged when reading. A very frequent addition is that of a cord or noose held in the mouth of the lion as if in play. Numerous small modifications and additions occur, such as stars on the body of the lion. Similar stars are found on Assyrian, Siberian, Tibetan and Chinese lions alike, thus clearly demonstrating a close common art-origin. What these stars represent does not appear to have been explained.

The relationship of the "true" or "spirit-lion" and the lion-dog is defined by the following extract from the Tibetan sacred writings: "In the West there was a Buddha named Manjusri (the Chinese Wenshu) who was always accompanied by a small 'hah-pah' (pet) dog and who travelled the four continents as a simple priest. On his travels he one day met a Taoist who begged him to obtain an audience with Manjusri. The Buddha invited the Taoist to accompany him to his home. When the Taoist had taken tea and rice, he again requested the Buddha to secure for him a vision of Manjusri Buddha. The Buddha told him that he must observe his vows with great strictness and that Manjusri 


\section{DOGS OF CHINA AND JAPAN}

would then be manifested to him. On this the Taoist, bursting into anger, cried vehemently, ' I am indeed keeping my vows. If not, why should I have come hither to see the Buddha ?' Then said the Buddha, 'If this be verily so, look up into the sky.' The Taoist raised his head and perceived in the sky a glow of five-coloured light together with clouds of five colours. In the heavens he saw the 'hah-pah' dog transformed into a mighty lion with the Buddha riding upon his back. The Taoist had affinity with Buddha in a previous incarnation, and consequently was enabled to see the true Buddha.*

It is of interest to note that St. Thomas the Apostle, who is believed through the traditions of the early Church to have propagated Christianity in India, High Asia and to the Walls of China, is represented by Indian tradition as having come to India riding upon a lion and accompanied by two dogs. $\dagger$

The association of a god with a canine assistant dates from the time of Anubis worship in Egypt. In Asia it can be traced back to a period anterior to the separation of the Persians and Hindus, the myth being found in the religions of both peoples. The dog of Mithras, god of the sky and a divinity of light, was venerated as the companion of the deity by the Persians. The worship of Mithras, deified before 405 B.C., was modified later by the star-worship of the Chaldeans, who identified Mithras with Shamash, god of the sun, by the Armenian religion, and by that of the Greeks of Asia Minor, who identified Mithras with Helios. About 60 B.c. the worship of Mithras was brought to Rome, and it became so fashionable that during the second and third centuries A.D. it constituted a formidable rival to Christianity. Mithras slaying the " earth-bull" with the help of his dog "Tibetan "Yuan Liu" Ching.

+ Marignolli, $\mathrm{x} 338$. 


\section{THE CHINESE LION}

is frequently represented in Roman sculpture. Persian basreliefs represent Mithras in the form of a youth wearing a conical cap, slaying the sacred bull, whose sacrifice was supposed to have originated terrestrial life. His dog is shown springing towards the wound in the bull's side. Accompanying these are a serpent, a raven, a lion, symbolizing the element fire, and a torch-bearer.*

Some believe that light on the origins of certain early Egyptian practices is to be found among the customs of the tribes of Africa. Speke $\dagger$ mentions that the heraldic device of Mtesa, King of Uganda, consisted of a white dog, a shield, a spear, and a woman. On state occasions Mtesa was accustomed to lead a small dog on a leash.

Another of the Lama Gospels says, "The lion is the King of Beasts. Its power of increase is without limit. Similarly it may diminish (at will) and become like unto a dog. Even so is the anger of man. He who keepeth his anger in subjection shall be free from calamity, but the woe of him that shall fail to bridle his wrath shall be even as the boundless increase in size of the lion. Through the lion's form therefore is the nature of anger known unto man." $\ddagger$

The dog-lion idea is illustrated by the Chinese written character for "lion." The most important Order of Merit given to high State officials in China from the earliest times included the decorations Great Instructor and Lesser Instructor (T'ai Shih, Shao Shih). Since the introduction of Buddhism these ranks, because Shih also means "lion," have been pictorially represented by lions. This custom originated in part from the fact that up to the T'ang Dynasty (A.D. 6I8) the "lion" and "Instructor" characters as well as sounds were identical. The root " $\mathrm{dog}$ " was subsequently

* See Mithras, Encyclopadia Britannica.

† "Travels to the Sources of the Nile."

$\ddagger$ Tu Lu Wa Ching. 


\section{DOGS OF CHINA AND JAPAN}

introduced into the "lion" character to make it clear that a beast and not a human being was indicated. The composite nature of the character aptly illustrates the blending of the identities of the lion with that of the dog in the Chinese imagination.

In Shantung the natives call the small lion figures which guard the roof-corners of all Chinese temples and date from the T'ang period "hai pah kou" (sea small dogs). The deerheads which guard the roof-trees are called "chang k'ou shou " (long-mouthed beast or beast-heads). The geomantic idea is that the dogs, resembling spirit-lions in being the denizens of the deep, are able to protect buildings against fire, and that the long-mouthed beasts devouring the wind are a sure protection against destruction by the powers of the air.

Images of the Buddhist lion are found in miniature before the altar of the god in many Chinese households. They undoubtedly participate in the veneration due to their Master, but though sometimes known to the unlettered as the dogs of Fo or Buddha, are not reverenced as dogs.

In India from the earliest times the Buddhists pictured curious leonine creatures with dog's heads among the mythical animals which worshipped at the sacred places in order to obtain a better incarnation.

The Chinese idea of subjection of lions to Buddha is exemplified by two stories from the Life of Buddha compiled by Pao Ch'eng, a Chinese monk of the Ming dynasty :

Devadatta turned the heart of King Ajatasatru against Buddha, and persuaded him to come to his city with a view to crushing him and his disciples under the feet of inebriated elephants. "On the next day at the hour of meat, Buddha and his arhats entered the city. Forthwith a herd of elephants rendered drunk with wine charged them with fierce trumpetI04 


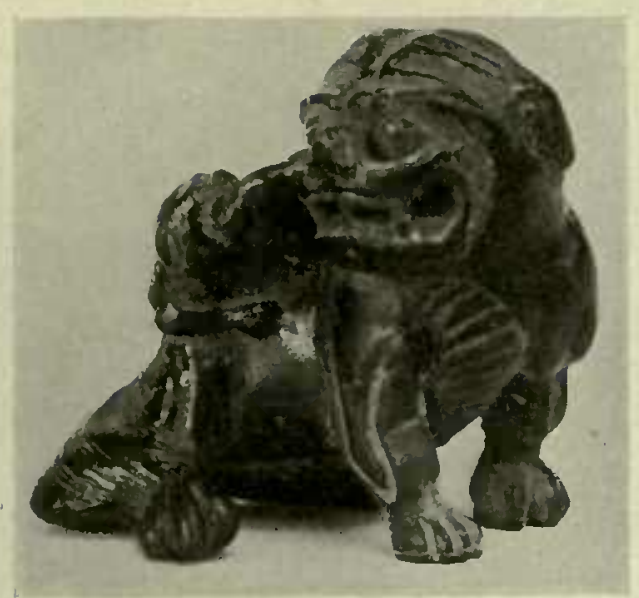

WOODEN LION, FFKING

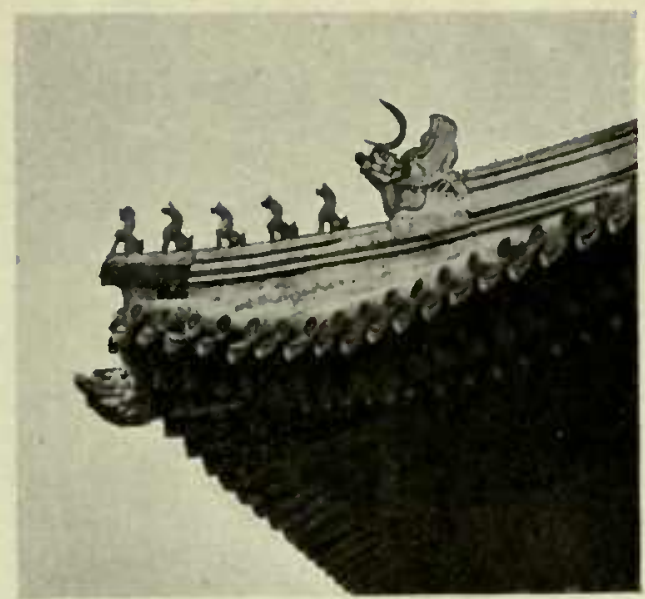

LION FIGURES GUARDING A CORNER OF PAVILION-ROOF. SUMMER PALACE, PEKING



Photo, Zumbrum, Peking



STONE PEDESTAL OF PAILOU BUILT BY THE EMPEROR YUNG LOU. MING TOMBS, NEAR PEKING. ETHEREAL LIONS WITH THE EMBROIDERED BALL AND TAPE-LIKE CORDS 


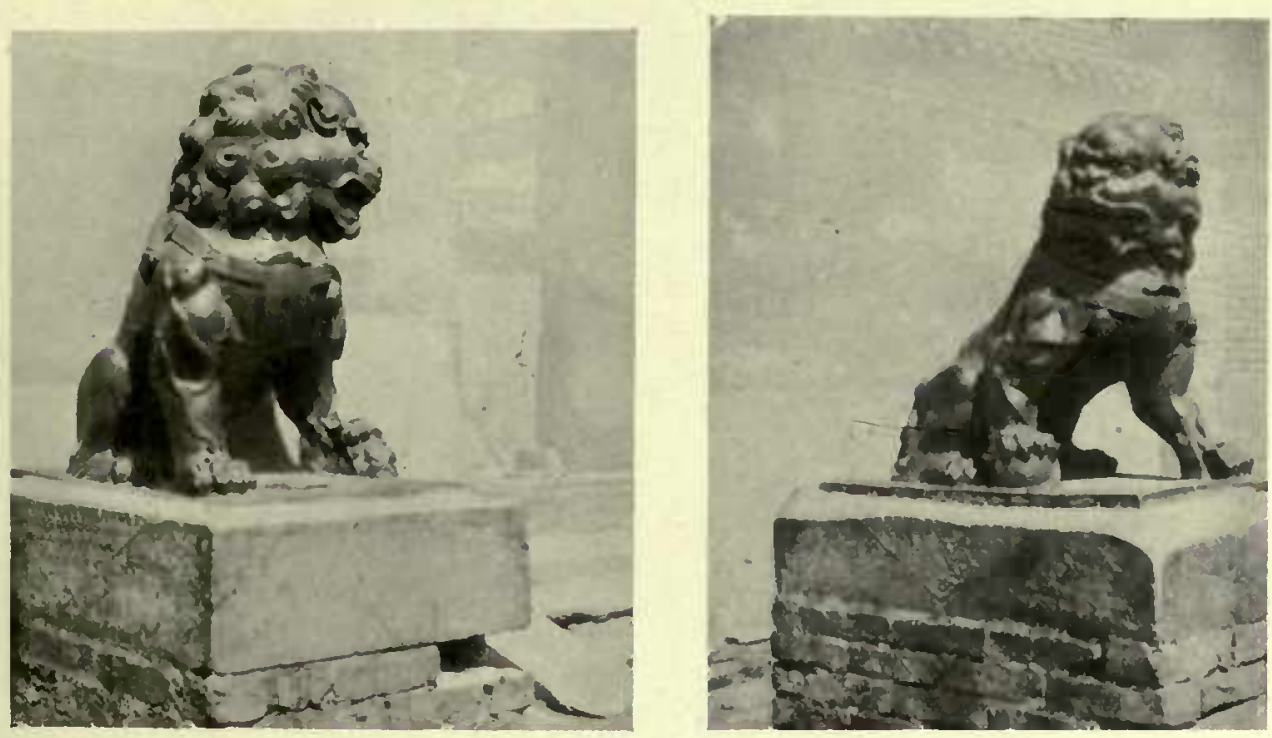

IRON LIONS. YAO WANG TEMPLE, PEKING

Dedicated to Cheng Lung, God of Medicine. K'ang Hsi Period

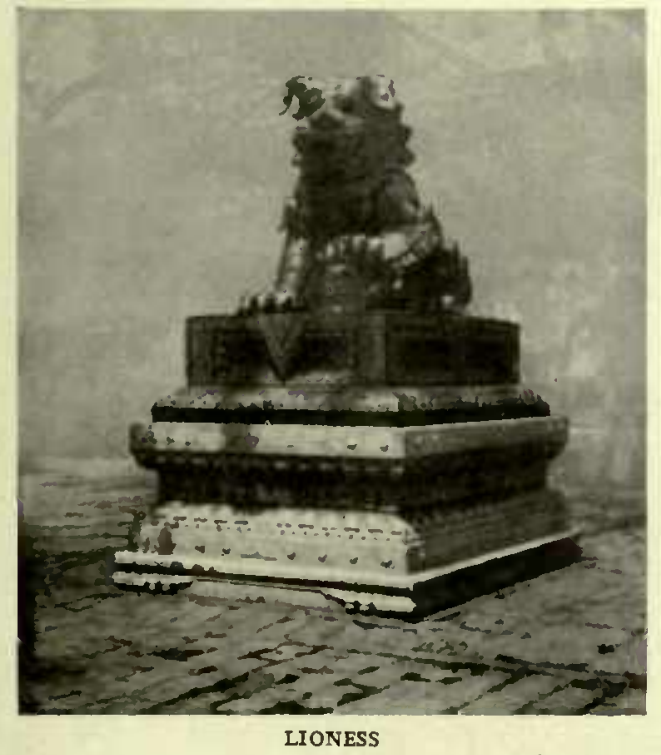

(LAMA TEMPLE, PEKING)

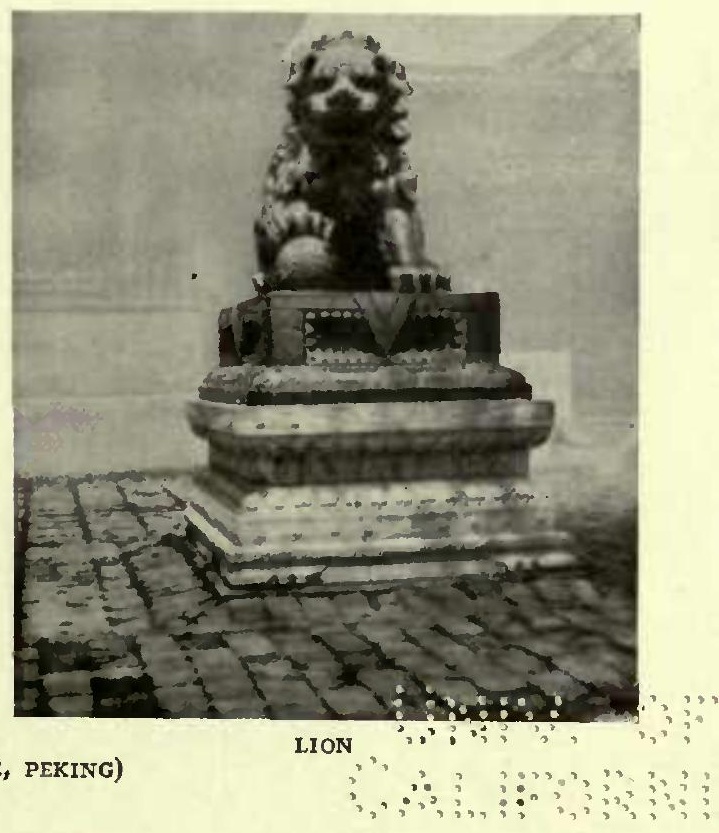

To face p. $\mathrm{IO}_{4}$ 


\section{THE CHINESE LION}

ings, overthrowing walls and bursting in houses. The arhats took refuge by lifting themselves into the air. Anandha alone remained with Buddha. The elephants bore down upon them, head to head. Then Buddha stretched forth one hand whose fingers changed themselves into five lions which

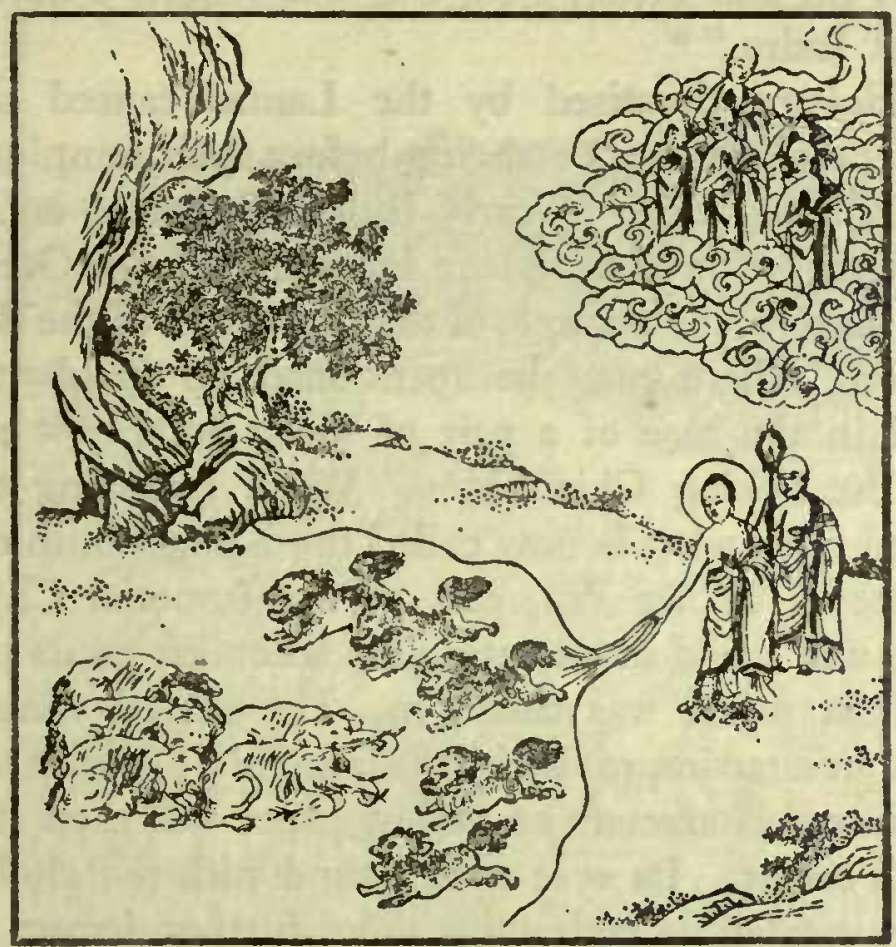

BUDDHA'S VICTORY OVER THE INEBRIATED ELEPHANTS FROM DR. L. WIEGER'S "BUDDHISM"

roared with a voice shaking heaven and earth. The elephants prostrated themselves in terror, marking their repentance by the shedding of tears."

A similar story is that of the subjection of the infuriated buffalo.

"Scarcely had Buddha entered the jungle when the wicked buffalo burst upon him at a gallop with erect tail and lowered horns, bellowing furiously. Buddha calmly extended his 


\section{DOGS OF CHINA AND JAPAN}

hand, whose five fingers became five lions. At the same time a circle of fire surrounded Buddha, the lions, and the infuriated beast. The buffalo, terrified by the lions and held captive by the fire, prostrated itself before Buddha, hung its head in a contrite manner and licked his feet. The buffalo ceased to eat and drink, died, and was reborn a deva in the heaven of Indra." *

The idolatry practised by the Lamas caused them to animate the lion images standing before their temples just as the feeling for nature in early Indian Buddhist art vivified the Western forms of sculpture introduced from Greece and Rome. As a recent example of the veneration of the Buddhist "true-lion" there may be mentioned an incident which occurred in the case of a pair of Ming lions now standing outside the Peking Chien Men. When removing these in May 1916 from what is now called the Kung Fu, in old days the palace of Prince Wu, east of the Imperial City, great difficulty was found in unseating the second from its pedestal. A Buddhist priest was called in. He offered wine to the spirit on an altar improvised before the idol. An incantation written in red characters on yellow paper was then affixed to the lion's breast. Its eyes were bound with red cloth. The idol then vacated its pedestal without further demur.

A more recent example is reported from Honan. "At Ucheng every expedient had been used to attract the rain. After processions to the city temple and putting the idol out to the sun a while had failed, the stone lions at the entrance of the temple were sprinkled with water. This failed also to bring the rain. The south gate was kept shut because 'fire is in the South,' thus causing travellers to make a detour of some miles in order to catch their morning train." $\dagger$

" "Buddhism," vol. ii, Dr. L. Wieger.

$\dagger$ North China Herald, February $7,1920$. 


\section{THE CHINESE LION}

Among the Assyrians the bull was the sign of the god borne to battle in the same way as the standards of the Romans, and, just as the Cross and the Crescent became the emblems of warring religions in later days, so the lion appears to have been adopted by the Buddhists, whose faith preaches peace

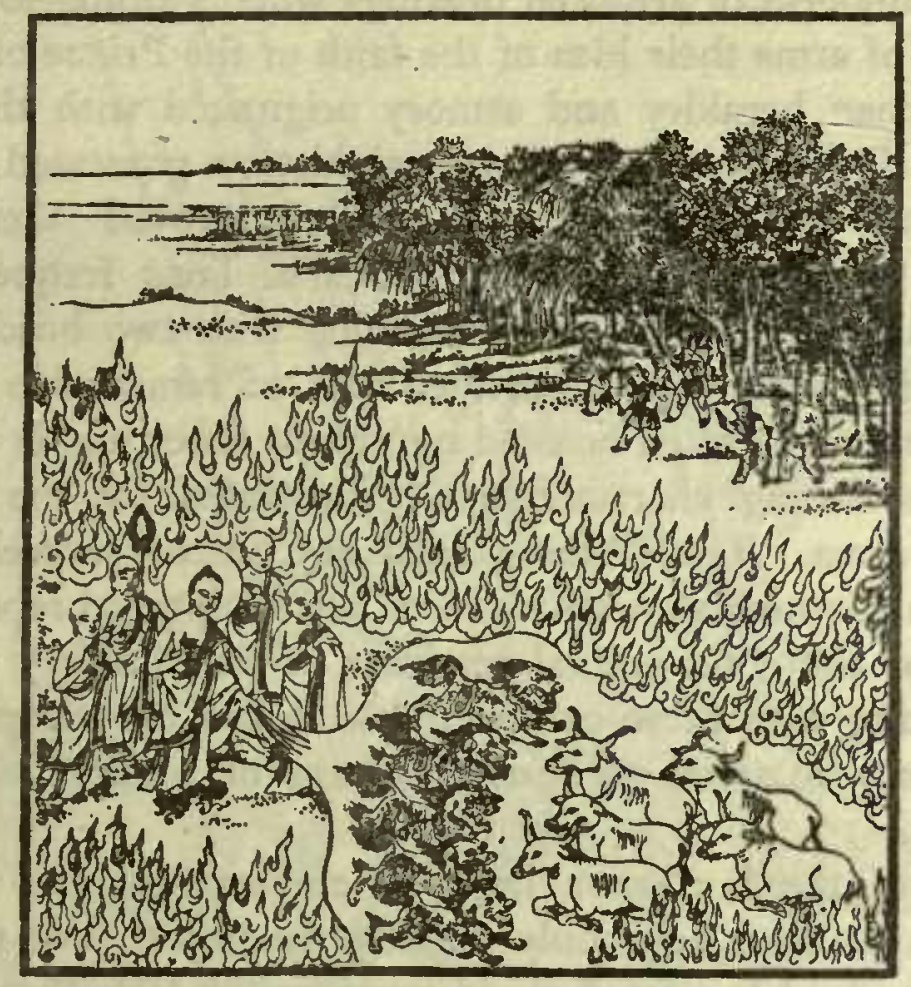

BUDDHA'S CONVERSION OF BUFFALOES. FROM DR, $\boldsymbol{l}$. WIEGER'S "BUDDHISM"

and humanity as their heraldic symbol. Buddhism has never appealed to the grim arbitrament of war for the imposing of its doctrines upon foreign nations, and it is therefore natural that its symbols should have failed to assume the accentuated and universally realized importance which, largely on account of warlike operations, accrued to the similar symbols of Christianity and Mohammedanism.

To the Western mind utilization of the King of Beasts to 


\section{DOGS OF CHINA AND JAPAN}

symbolize docility and the subjection of human passions under the benign influence of religion appears so great a contradiction as to be almost paradoxical and even grotesque. It may, however, seem to the Chinese equally grotesque in the Crusaders to have adopted lions of wonderful form as the commonest of armorial bearings when battling to extend by dint of arms their idea of the faith of the Prince of Peace.

European heraldry and armory originated with the Crusades. The knowledge of natural history possessed by the mediæval artists was limited. They proved themselves capable of depicting shaggy figures of lions frequently of astonishing tenuity of body, crowned with two heads, their tails being sometimes bifurcated and of remarkable length. These creations often boasted numerous other highly fanciful and astonishing characteristics* illustrated by the British coat-of-arms. The Chinese need not be too severely criticized in adopting somewhat inaccurate sculptured representations for the chief animal retainers of Buddhism $\dagger$ and for connecting with these certain myths which are composed of too flimsy material to resist the test of modern scientific inquiry.

Use of the lion as a heraldic emblem by the Chinese appears to have been only slightly developed, but that the heraldic idea has existed is indicated by the facts that the use of leonine images before doorways was restricted by law to temples and official buildings, that the size of their bronze or stone representations indicated the importance of the building

" See Davies, " Guide to Heraldry."

† The inaccuracies, moreover, are partly Indian. "The conventionalized lion of Indian art betrays its anterior Asiatic character, particularly in the arrangement of the mane. A series of lion-like animals appear in art as early as the Asoka period. Especially these conventionalized lions became still more baroque. The so-called sardulas (N. India) and yalis (S. India) of the later Indian art are overloaded with shaggy hair and petty curls." A. Grünwedel, "Buddhistische Studien," vol. v, p. 70.

108 


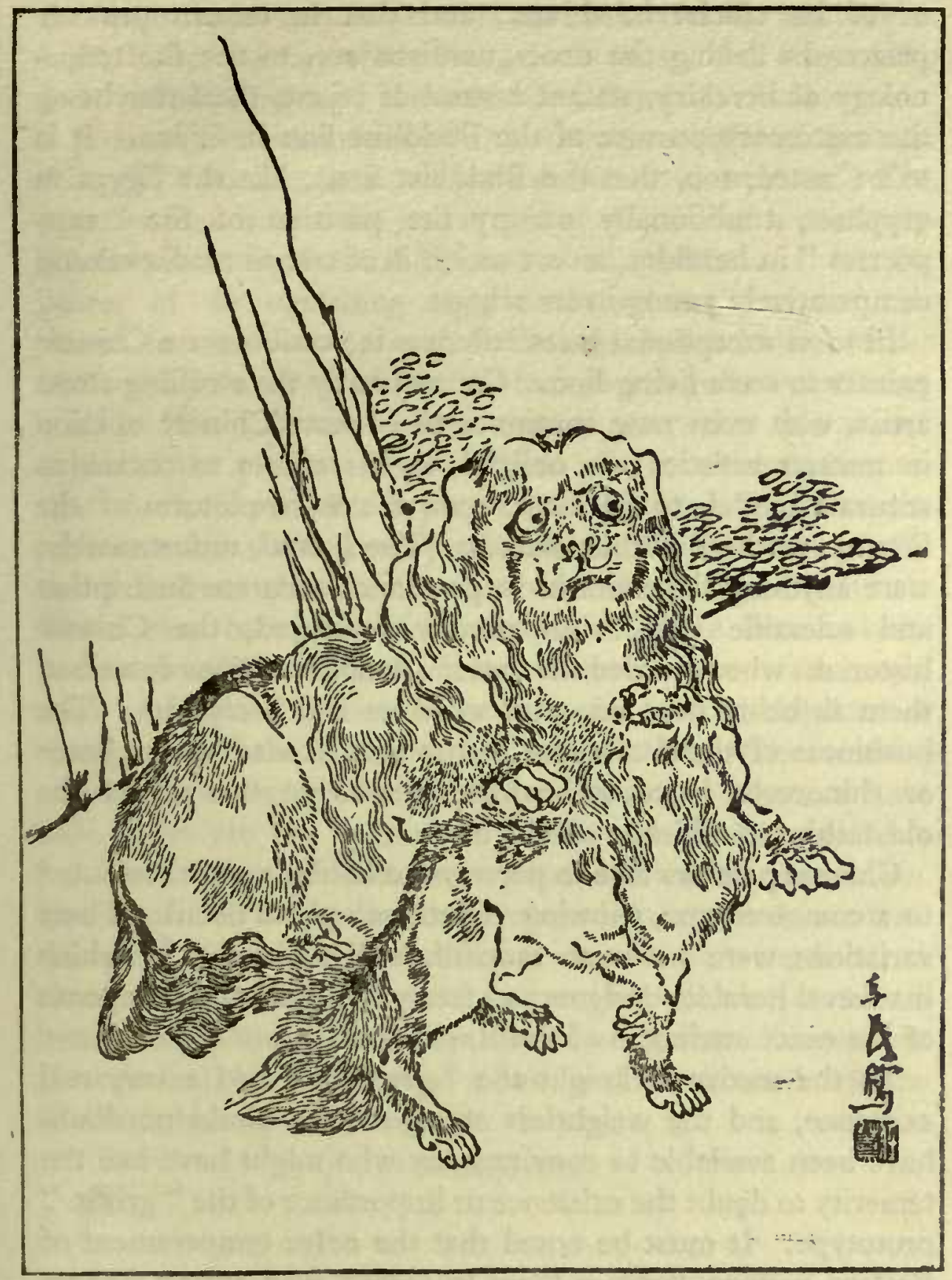

RECENT PAINTING OF LIONS (POPULAR TYPE) BY THE FAMOUS PAINTER REN HSUN 


\section{DOGS OF CHINA AND JAPAN}

or of its official inhabitant, and that in certain princely palaces in Peking the door-guardians are, to use the terminology of heraldry, statant instead of sejant, the latter being the customary posture of the Buddhist lion in China. It is to be noted, too, that the Buddhist lions, like the Egyptian gryphon, traditionally occupy the position of the "supporters " in heraldry, an art which is of course mediæval and comparatively young in its origins.

In most exceptional cases only was it possible for a Chinese painter to see a living lion. Consequently the strolling street artist, who even now continues to educate Chinese opinion in matters artistic, was obliged, in his efforts to obtain an accurate model, to fall back upon the word-pictures of the literary, or the Buddhist statues. The literati, unfortunately, were anything but efficient in powers of accurate description and scientific detail. As already remarked, the Chinese historians who recorded the first importation of lions described them as being bearded, with whiskers and hairy ears. The bushiness of their tails and manes was likened to the horse or rhinoceros hair-tassel which figured on the top of the old-fashioned Chinese official hat.

Chinese painters love to portray the lion in a style restricted to a common type, showing variations only in detail. These variations were never so fanciful as the liberties in which mediæval heraldic designers so freely indulged at the expense of the exact attributes of the Royal Beast.

To the mediæval knight the "gryphon" had a very real existence, and the weightiest of arguments would no doubt have been available to convince any who might have had the temerity to doubt the existence or importance of the "griffin " prototype. It must be noted that the naive temperament of Eastern nations disposes them to regard even animal images used decoratively as the living animals they represent. The I IO 


\section{THE CHINESE LION}

European unicorn is a blend of the horse and the bull. The head, body and legs of the animal are those of a horse; the feet, tail and horn of the nature of those of a bull.

It is a point in favour of the common origin of symbols that the Chinese have also their lion and unicorn. The popular idea is that the unicorn is of the size of a goat with a horn projecting from the centre of its forehead. It has the power of distinguishing right from wrong,-and for this reason legend has employed it, like the Iodan Moran of the Hebrews, in a court of justice, to indicate guilt by pointing with its horn. Many Chinese writers assert that this animal exists to the present day in Tibet. Chinese bronzes represent the unicorn with a parrot on its back. In these, the unicorn symbolizes dumb justice, while the parrot stands for the talkative advocate capable of expounding the truth. There may be a possible comparison of the lion and the unicorn in China with the lion and the unicorn of the royal arms of England. Each nation appears to hold the lion for strength and the unicorn for justice. No other existing nation possesses these emblems, and the only others to have held them are the houses of Judah and Israel. In many passages in the Old Testament Judah is referred to as a lion. Israel, on the other hand, is referred to variously as both animals. "He (Israel) hath as it were the strength of an unicorn : he shall eat up the nations his enemies, and shall break their bones, and pierce them through with his arrows. $\mathrm{He}$ couched, he lay down as a lion, and as a great lion: who shall stir him up ?"*

* Numbers xxiv. 


\section{CHAPTER VI}

\section{SYMBOLISM OF THE BUDDHIST AND LAMAIST LION}

T $\mathrm{N}$ Christian ecclesiastical art the lion is sometimes used to represent the devil, who goes about " like a roaring 1 lion," but more frequently symbolizes the Redeemer himself on account of its royalty, courage, watchfulness, strength, and alleged mercy to the fallen. At the church door lions symbolized the watchfulness of God over His people, noting their going out and their coming in, and spying out all their ways, watching also for their protection and to guard the sanctuary.*

The significance of the lion in Buddhism is altogether different. "Buddha placed the lions before his temple that his priests might remember to subject their passions." The Lamaist idea is that Buddha on entering his temple has ordered the two lions which have accompanied him to seat themselves upon the altar-cloth-covered tables set at the door, and that by awaiting his return in motionless obedience they serve as a reminder of the subjection of the passions by the Holy Creed.

It appears likely that the Tibetans owe the form of their lion monuments to Greek travelling artists, and much of their lion lore to the Egyptians. In Egypt the lion was a hieroglyphic or sacred character before the Chinese began to write and long before Tibet or the lion became known to " "Sacristy," Herr B. Eckl. 

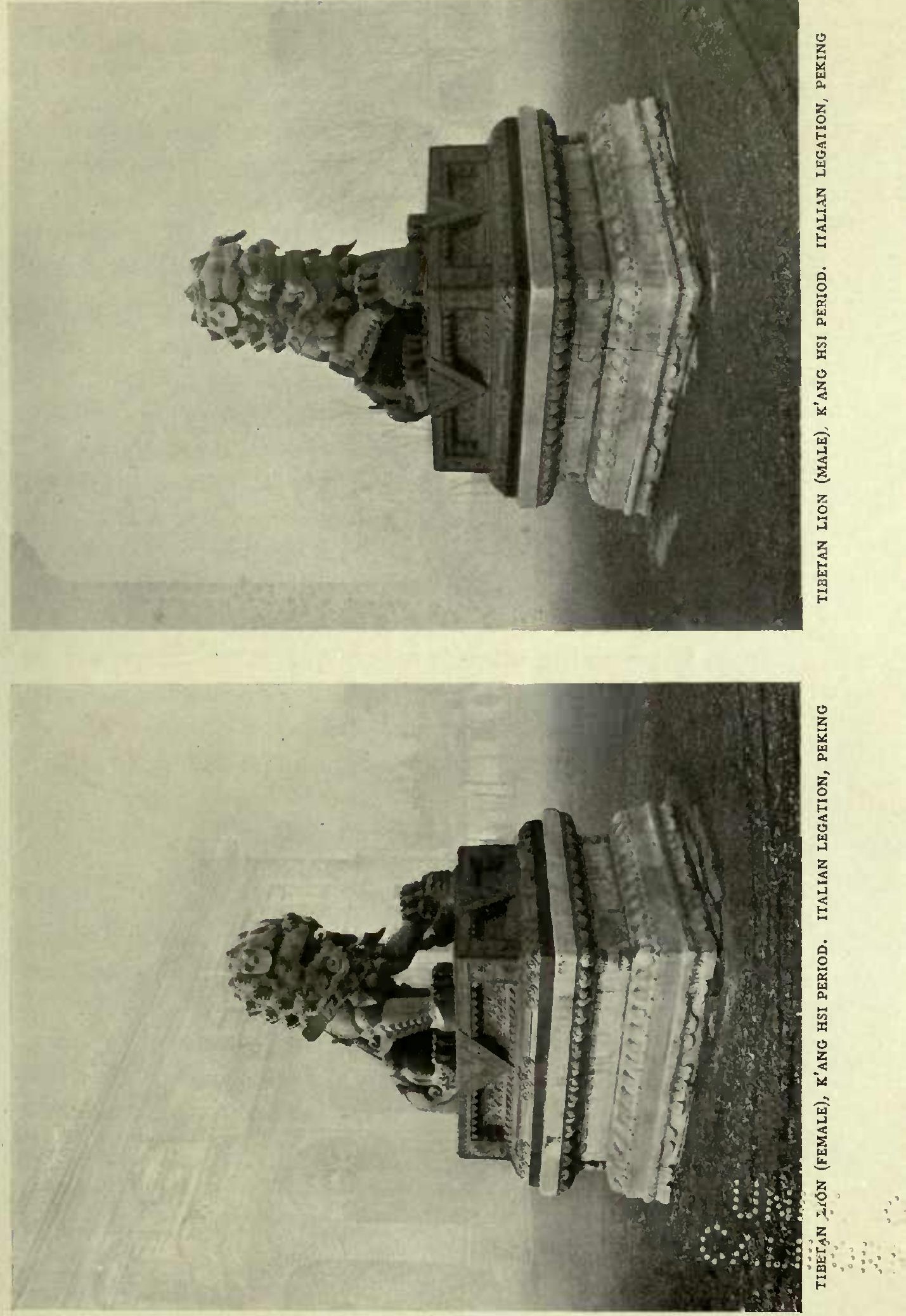

To face $p, x: 2$ 

the ancients of the Far East. Wallis Budge states that the Egyptians believed that the gates of dawn and evening through which the Sun-god passed each day were guarded by lion-gods. In order to keep evil spirits and fleshly foes from those who dwelt within, they placed statues of the lion to guard the living at the doors of their palaces, and to guard the dead at the doors of their tombs.* Other authorities state that being persuaded that the lion slept with his eyes open, the Egyptians placed the figure of this animal at the entrance of their temples. $\uparrow$

Another monument common to Buddhism and the religions of Western Asia is that of a Divine Being riding upon a lion. The idea of subjection of the King of Beasts to the might of religion is no doubt common to all such representations. Cybele, standing on a car drawn by lions, was worshipped in Phrygia. Atargatis, the great Syrian goddess of Hierapolis-Bambyce, was portrayed sitting on lions and wearing a tower on her head. In the rock-hewn sculptures of Bogaz-Keui, a youth stands on a lioness or panther immediately behind the great goddess, who is supported by a similar animal.f

It appears likely that the Oriental deities, represented as standing or sitting in human form on the backs of lions or other animals, were in the original religions indistinguishable from the beasts themselves. With a growth of the knowledge and power of man he discontinued worship of the bestial shape, and gradually recognizing that his worship was directed rather towards the abstract principle of power and majesty, super-imposed a human or divine form having the lower nature in complete subjection.

"A. E. Wallis Budge, "The Gods of the Egyptians."

† Buffon, "Histoire Naturelle," vol. vi.

I "The Golden Bough," Hazer, vol. i, p. 137. 


\section{DOGS OF CHINA AND JAPAN}

Chinese Buddhism * represents Wenshu Buddha, the God of Learning (the Tibetan Manjusri), as riding upon a lion, in company with Kuan-yin, Goddess of Mercy, riding upon a hou, and $\mathrm{Pu}$-hsien upon an elephant, pacifying the warring demons of the earth at the beginning of history. Transference of the attributes of one divinity to a supporter is illustrated by the fact that the Buddhists accord to the lion greater wisdom than to any other of the lower creation. Its sagacity is likened to the learning of its master, Wenshu.

The harness with which all Lamaist lions are adorned assists in symbolizing the servitude of the lion to Buddha.

The lion was to some extent used in the sense of being the champion of Buddhism, also as a defender of Buddha and of the faithful; for Buddhists often burn two lions made of fir twigs at the funeral of important officials, with the object of expressing a hope that the guardians of Buddhism may protect the deceased in the life to come.

A further use of the simile of lion-subjugation occurs in the Lamaist writings :

"Buddha released the wild beasts of a certain mountain from the depredations of the lion by causing them to read his Bible. The lion, finding that he no longer hungered for their flesh and that they lived in no fear of him, discovered the secret of the miracle from the fox. The lion then asked Buddha for instruction, and as a result his temperament was changed to active benevolence. By this means it is proved that the power of Buddha's Bible in leading to do good is without limit. The lion crouches before the seat of Buddha to eternity. Two lions sit before his seat, and eight lions around it."

"Fung Shen Pang, "Popular Book of Superstitions" (recent, but universally known in China.)

† Cha Pu Lao P'an Yuan Bible.

I 4 


\section{SYMBOLISM-BUDDHIST AND LAMAIST LION}

This is therefore a Buddhist realization of the pious thought contained in the Hebrew prophecy of the time when " the leopard shall lie down with the kid; and the calf and

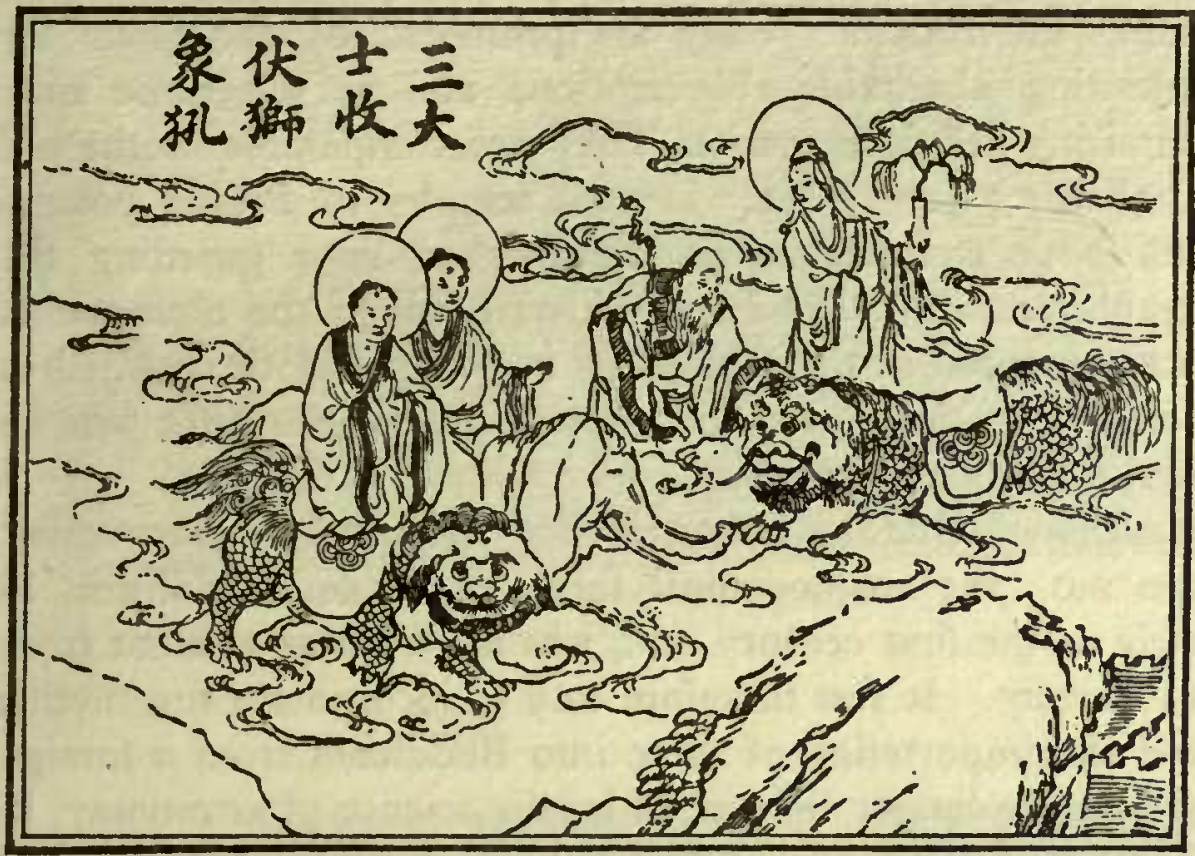

WENSHU (MANJUSRI) BUDDHA RIDING UPON A LION, PU-HSIEN UPON AN ELEPHANT, AND KUAN-YIN MOUNTING A HOU (FUNG SHEN PANG)

the young lion and the fatling together," "and the lion shall eat straw like the ox." *

The attributes of the two lions before Buddhist temples are celebrated at religious "Lion-masques" held from time to time all over China, Tibet, and in Japan, where, as remarked by Captain Brinkley, the so-called Dog or Lion of Fo (Shishi no Kachira) is carried in the Sano procession in Tokyo. In China a pair of lion-head cardboard masks with cloth bodies, counterfeiting the temple guardians, are carried in procession from certain temples. Sometimes they are made to halt at the temple door and playfully bar ingress to - Is. xi. 6-7. 


\section{DOGS OF CHINA AND JAPAN}

demons. They are then made to follow a large knitted ball to some eminence, where they sport with it to the delighted applause of large audiences.

These plays are known as "Shuah Shih-tzu" or "Exercizing the Lions." They are promoted by the pious for collecting charitable subscriptions and at the same time acquiring religious merit. They are comparable to the old English mystery plays. Several temples in Peking possess lion-mask counterfeits of the pair of lions guarding the temple entrance. The embroidered ball of the monuments is represented in these plays by a coloured cloth attached to a staff. In the illustrations the player on the right will be seen holding this emblem.

Although Buddha is now known to have been born about $55^{\circ}$ B.C., the cosmogonical form of Indian Buddhism, as early as the first century A.D., was set forth as existent from all eternity. It was therefore easy to incorporate sun-myths, and the importation of these into Buddhism from a foreign source was largely influenced by the science of astronomy, in which the Chaldeans and Egyptians were remarkably advanced as early as 4000 years before the Christian era.

To a sun-myth is probably due the representation of an embroidered ball under the paw of the male Lamaist lion in the temple-door monuments. This lion-and-embroideredball ("Shih-tzu Kun Hsiu Chiu ") design is the commonest motif in Chinese art and, as illustrating the triumph of wit over brute force, supplies one of the most frequently used proverbs in the language. Ancient pictures of tribute embassies almost invariably show the King of Beasts tamely following an embroidered ball.

It may be recalled that each of the Swedish heraldic lions rests a forepaw upon a globe, and the lion of St. Mark rests its right paw upon a copy of the Gospel. There are two lion I 16 


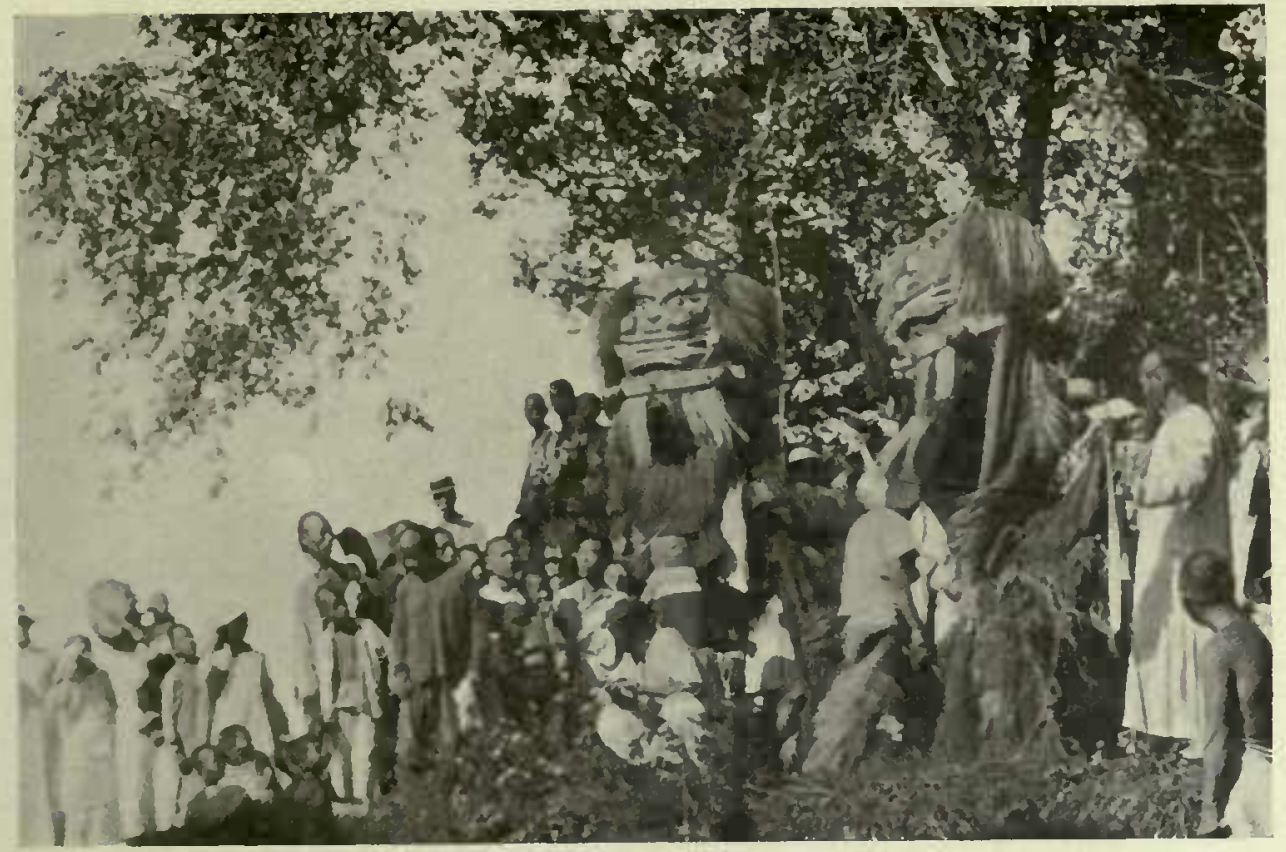

BUDDHIST LION-MASQUE, PEKING, I9I 4

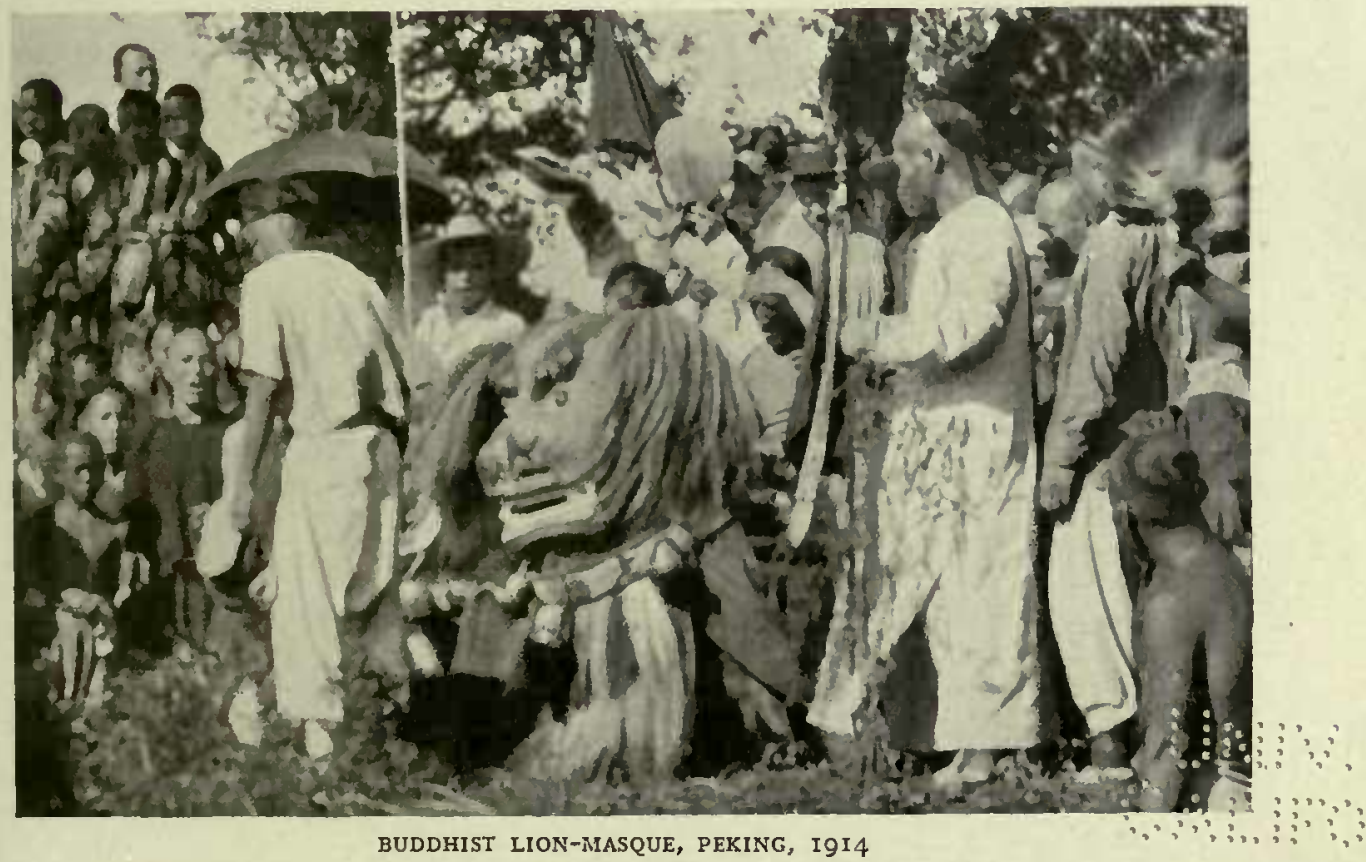

To facs $p .1 \pm 0$ 
$\because 6 \quad \forall$

a 40 


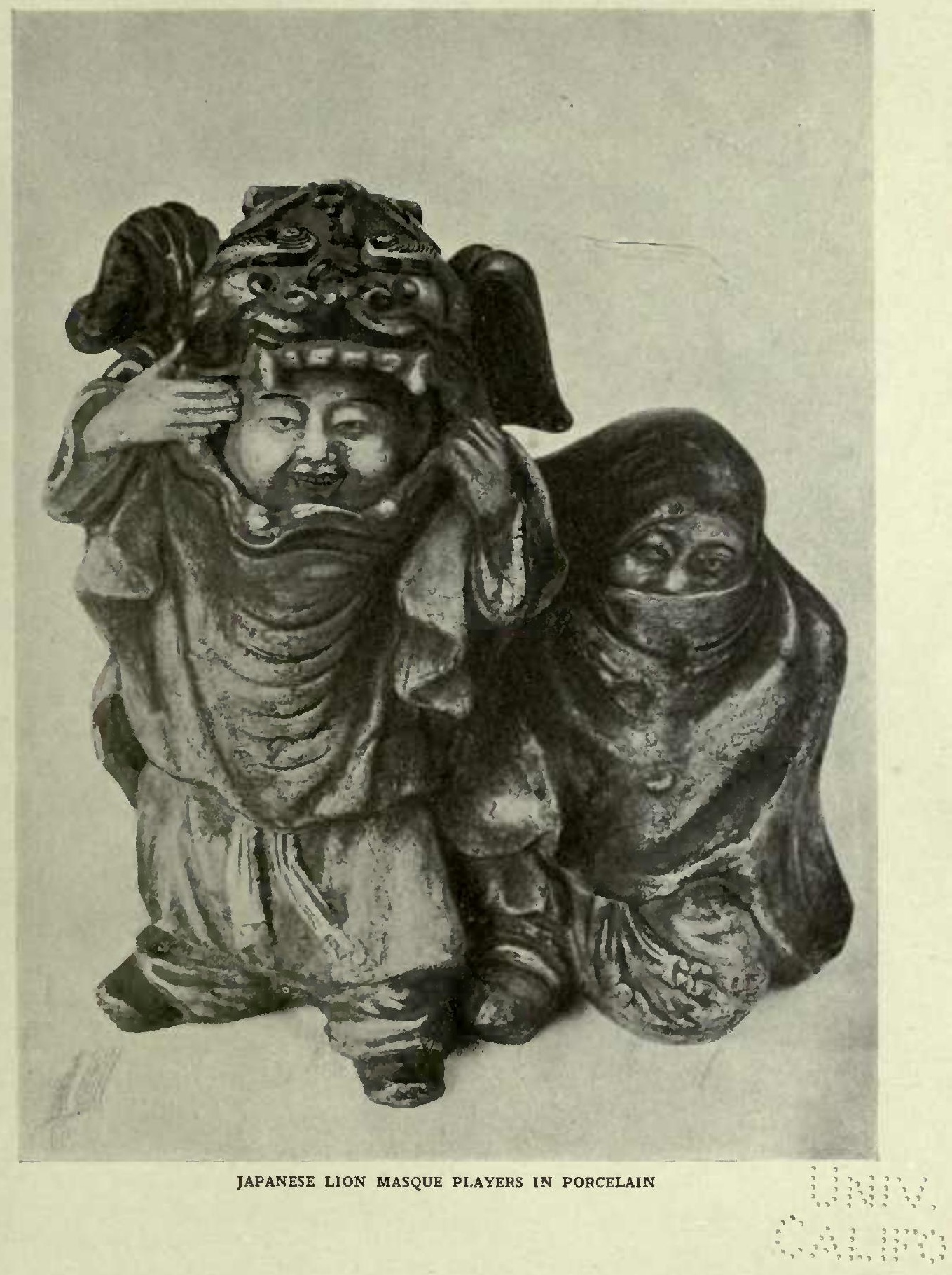





\section{SYMBOLISM-BUDDHIST AND LAMAIST LION}

gods in the ancient Egyptian ritual. They support the sun and are attached to the limits of heaven, the extreme bounds of the sun's journeys.* The ancient Egyptian gods, "Shu with his sister Tefnut," are types of the dual lion. They are the servants of the sun-god. The one lion is a god of the Southern heaven and the horizon of the West supporting the sun as it sinks, the other of the northern heaven and the horizon of the East pushing forward the sun as it rises." * It is interesting to note that the lions before Buddhist doorways are almost invariably ranged east and west-east to typify the Yang or male influence, and west to characterize the Yin or female influence.

In Japanese astronomy the Chinese lion symbol occurs as the eleventh of the twelve celestial signs. It is also commonly found in Japanese art. The Japanese, however, refer to this sign as that of the dog. This error appears to be due to a curious misunderstanding of Foist lore on the part of the Japanese Buddhists, who derived their religion from China through Corea. This may perhaps be an instance of the Egyptian influence which favoured dog-worship and appears to have had no small importance in Japanese sun-worship in Shintoism. The Chinese gave the dog no place among the twelve celestial signs, but at a date which must have been posterior to the introduction of Buddhism did give a place to the lion, which, of course, only became known to them with Buddhism. The Japanese appear to have mistaken the fanciful Chinese Foist representations of the lion for dogs, calling them the "dogs of Fo." They adopted the same forms, the pair Koma Inu (Dog of Corea) and Ama Inu (heavenly dog), practically identical in shape

" "Book of the Beginnings," G. Massey.

$†$ Except perhaps in art of the Han period. See Laufer's " Chinese Pottery of the Han Dynasty," p. 242. 


\section{DOGS OF CHINA AND JAPAN}

with the Chinese lions, but without the attributes introduced into China by the Lamaists. Such lion-guardians protect the entrance to the tomb of Tokugawa Iyesasu, who died in A.D. 1604, at Nikko. These guardians are commonly found in Japan as in China at the entrances to temples (miya). Another instance of error in knowledge of Chinese Buddhist art in Japan is the illustrating and describing of a Chinese lion as a kylin by Kaempfer, who derived his information from a well-educated Japanese. The Shinto priests, too, have lion-images in their temples, though these are clearly Buddhist.

The throne of the Dalai Lama at Lhasa is supported by carved lions.* Similarly lions are found at the foot of the Japanese Imperial throne, serving as supports to the golden chair upon which the Mikado sits. They sit upright upon their haunches with straight forelegs. Their mouths are gaping, their mane is curled in tufts, their tails are bifurcated, and according to Griffis they are called "Corean dogs." Griffis thinks that they may here typify the vassalage of Corea, said to have been conquered by the Empress Jingu. She called the King of Shinra "the dog of Japan." +

The lioness on the western side of the Chinese doorway has her left paw resting upon an upturned lion-cub, and her claws are in its mouth. The whelp is supposed to be sucking milk through the claws, for the old Chinese belief is that the lioness secretes milk in her pads.

These legends may be compared with the old European superstition linked in medixval times with Christianity, that the lion-whelp was born dead, and brought to life on the third day by being breathed on by its father.

These two Chinese superstitions are no doubt due to

- "Thibet the Mysterious," by Sir Thomas Holdich, p. 3 I8.

† Griffis, "Corea the Hermit Nation," p. 52. 


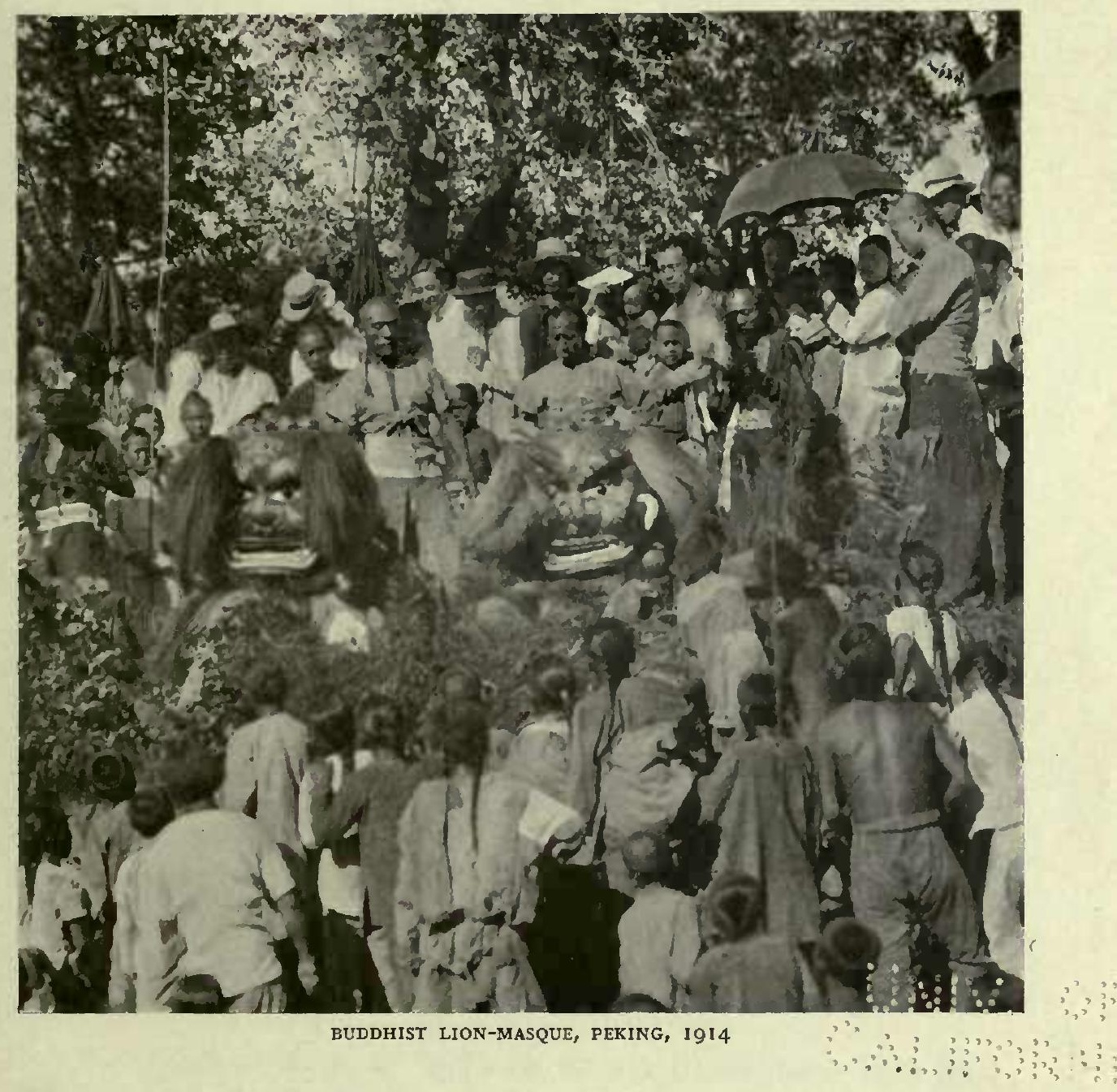


$\because 6 \quad \because \because 9$

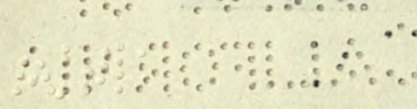




\section{SYMBOLISM-BUDDHIST AND LAMAIST LION}

Lamaism, for the Scriptures read: "When a man wishes to obtain the milk of lions, he first makes an embroidered ball of many colours and places this upon their path. Upon seeing it the lions are attracted. Having played with it for a long time the ball is soaked with milk. Thus may man obtain its milk from the ball. Thence comes the saying of the ancients that man is the wisest of all living beings.- This is the very truth." *

To the Chinese, Corea, possibly on account of its being almost surrounded by the sea, is even more the home of the ethereal lion than is Tibet. One of the earliest of Chinese myths credits the sea with being the home of dragons. In modern Chinese fable the dragon has nine children, of which the lion is one. The Coreans turned this belief to great profit up to recent years by stimulating the Chinese faith in the great efficacy of the "Corean purify heart pill "-a nostrum which, considered to be extraordinarily powerful as a sedative for fever, recently shared with ginseng root the wide reputation which caused its market value to be its weight in gold. The pill was said to contain a large proportion of lion's milk collected, in the manner indicated by the Tibetan biblical legend, from cotton and cloth balls exposed by night at the ends of the flag-poles of Buddhist temples, and particularly accessible to the numerous lion-spirits frequenting Corea on account of its proximity to the sea. Since the abolition of the Corean embassies to Peking and the annexation of the Hermit Kingdom by Japan, the sale of this old-world nostrum has greatly diminished.

Among the patrons of early Northern Buddhism were the Scythians and Indo-Persians, a race of sun-worshippers. The placing of a whelp beneath the paw of the western, or female, lion outside Chinese temples may also be connected with

* P'a Erh Ch'in Gospel. 


\section{DOGS OF CHINA AND JAPAN}

sun-worship. The ancient Egyptian sacred year began with the sun in the sign of Leo, constituted by two lions and a whelp. It may be recalled, as mentioned earlier, that " the young lion and an old lion that couched "were the twin-lion blazon of Judah. It is interesting to note that the Chinese lions were frequently represented as holding in their jaws a broad ribbon, often pictured as a piece of string or rope.

In the Egyptian ritual the stars or planets are described as hauling the sun* along with ropes, and the balance of the equinox was ruled by the two lion-gods who pulled at the ropes of the scales. $\uparrow$ Again, in Southern Pacific mythology -especially that of the Maori, which is startlingly similar in many respects to the Egyptian - the sun hauls the full moon up over the horizon by means of ropes. It is just possible that such ropes have some mythological connexion in an early conception common to these widely separated races. The existence of the old sun myth is further recalled by the frequent picturing of the stars on the head of the Lamaist lions. These are frequently found in potteries of the Ming period, and also in cloisonné incense-burners of the time of Ch'ien Lung. The Chinese have no constellation Leo. Similar stars are, in Scythic $\ddagger$ art, found on the ibex and the horse and, in Assyria, upon lions. They much resemble the stars found upon Tibetan luck-flags, possibly pointing to the use of the objects as omens and charms. The practice of using miniature lions as charms is universal in China to this day.

- Sun-dog. This name is not in use in China. A pair of lions, each with a ball beneath one of the fore-paws, is placed before many temples of the Shinto religion in Japan. The Shinto priests were originally worshippers of the sun. Their religion, like the sun-worship of the Egyptians, was much older than Buddhism, but in later periods the two neighbouring beliefs have mutually borrowed many attributes. It is possible that the Shinto association of lions with sun-worship may have led to the use of the term "sun-dog," current in Japan.

+ "Book of the Beginnings," G. Massey. † "Scythians and Greeks," Minns. 


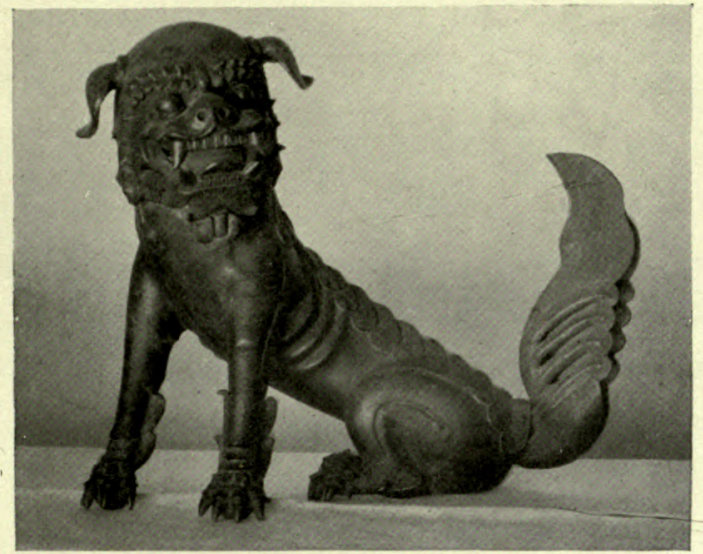

BRONZE INCENSE-BURNER, SUNG PERIOD (AUTHOR'S COLLECTION)

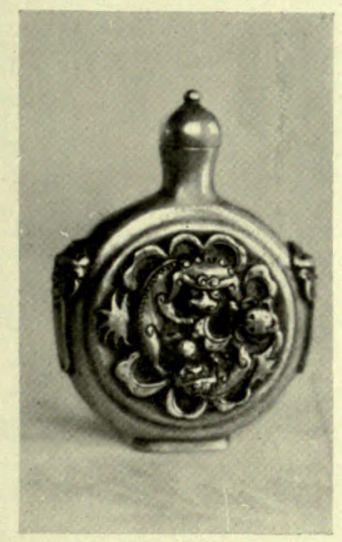

SILVER SNUFF BOTTLE (AUTHOR'S COLLECTION)
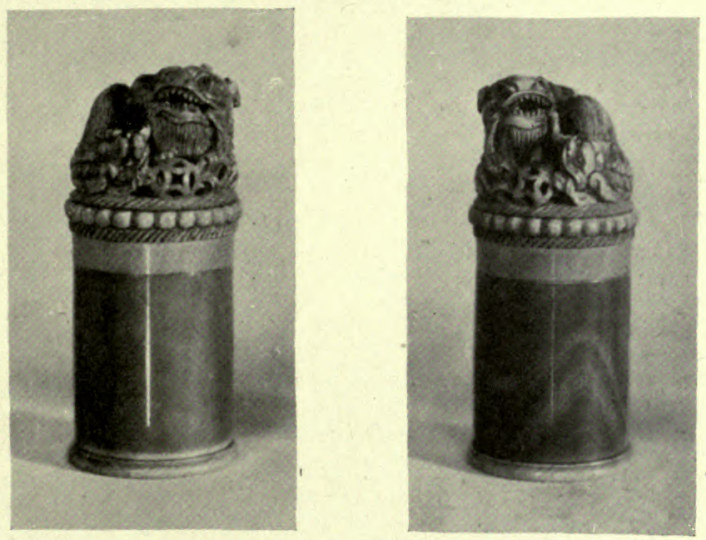

PAIR OF IVORY OPIUM BOXES (AUTHOR'S COLLECTION)

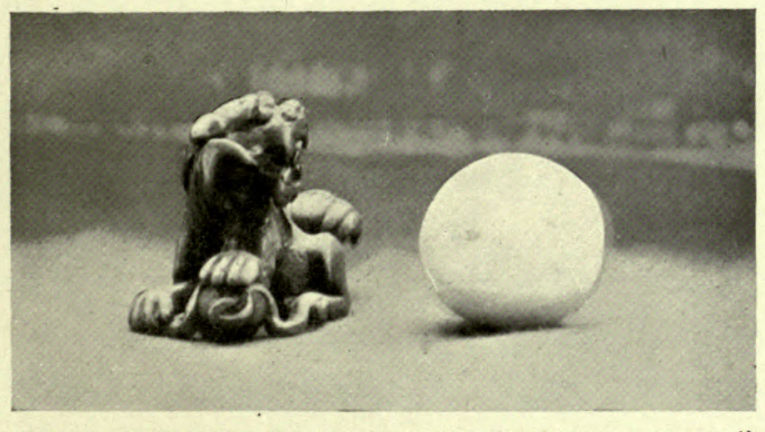

MINIATURE BRONZE LION AND A COREAN " PURIFY HEART PILL " (LION'S MILK PILL)

RECENTLY PURCHASED IN PEKING

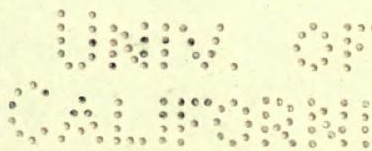


Another link in the evidence connecting the lion with sunand fire-worship exists in the belief, current during the mediæval period, that the lion was associated with fire and smoke. Consequently, a very large number of incenseburners fashioned in the shape of lions can be assigned to this period. These burners were usually hollow, the smoke being caused to issue from the lion's jaws.

Among the early mediæval Christians the lion sometimes was used to represent Christ Himself. The Buddhists actually borrowed from the lion and gave to Buddha certain leonine physical characteristics. Conversely, their spirit-lions in monuments were endowed with certain remarkable nonleonine characteristics which were derived from representations of Buddha himself. Among these may be noted absence of the outward evidences of sex, domed head, curly tufts of hair on the head, and a long tongue.

Among the thirty-two superior marks which distinguished Buddha from others of the human race were :

(4) Between the eyebrows a little ball shining like silver or snow.

(12) The tongue large and long.

(13) The jaws those of a lion.

(17) The skin having a tinge of gold colour.

(19) The upper part of the body that of a lion.*

It is not surprising that in breeding dogs to resemble the Lamaist lion as closely as possible, Chinese breeders have encouraged the development of physical characteristics which in Buddhist lore in some cases were common both to the lion and to Buddha himself.

The Lamaists were so much at a loss to explain their lion's twisted curls that they invented a legend, now current, that Buddha remained so long in motionless contemplation that

" "Buddhist Art in India," V. Burgess. 


\section{DOGS OF CHINA AND JAPAN}

the snails crawled over his head. Lamaism suggests that the lion had five large curls at the top of its head to simulate the flags worn in the ancient head-dress of high military officials. Buddha said: "Upon the lion's head are five hair-curls. The middle one is a general, and the others like unto. his four flags. The nine hair-curls below are their support."

On referring to Egyptian mythology, we find that the two lion-gods wore a special feather head-dress. Assyrian models, not later than the seventh century B.C., show a sheath-like head-dress which possibly began to be represented as curled at about the same time that the Buddhists, who originally represented Buddha with free-falling, waved hair, began to ascribe to their deity, as one of his superior marks, short and curly hair.

Tufts of hair on the legs of Chinese lion-statues have been mentioned. The well-developed fringes on the legs of "Pekingese" dogs are comparable to them. The Assyrian lions were shaved when domesticated. Of the mane, only a frill or collar was left round the face; on the body some tufts and bands of hair were left on the back, along the flanks, and behind the thighs. The tuft was left at the end of the tail.*

" "The Book of the Lion," Sir A. Pease. 


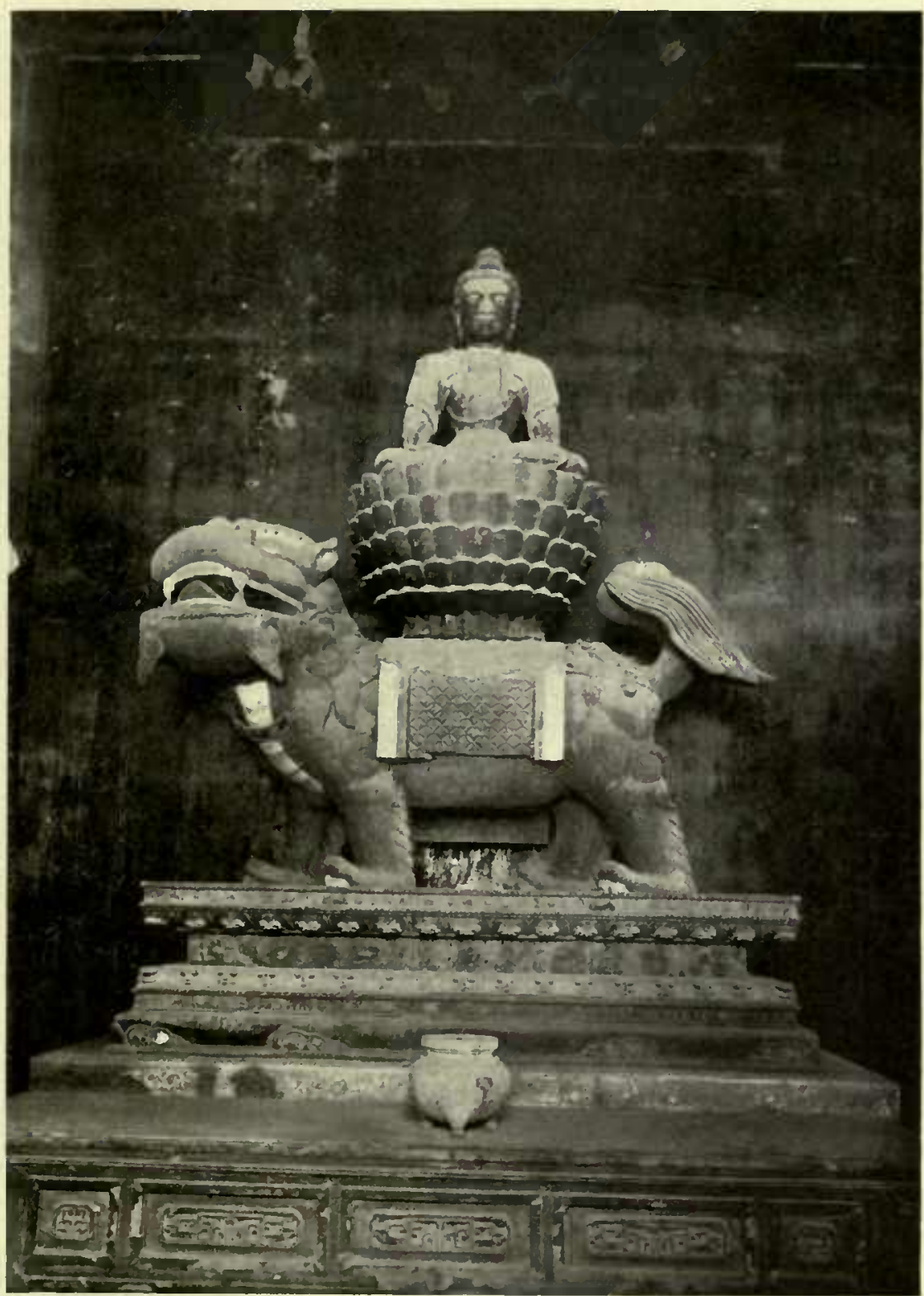

Photo, Zumbrum, Peking

WEN SHU (MANJUSRI) BUDDHA RIDING ON A LION (HUANG SSU, NEAR PEKINs)。 The Huang Ssu was built in 1647 , by the Emperor Shun Chih. (This temple was
recently destroyed by fire)

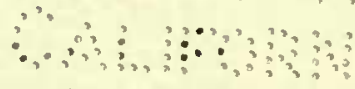


$\because \quad \because \because \vdots \vdots \vdots \vdots \vdots$

$\because \because \vdots \vdots \vdots \therefore \cdots$ 


\section{CHAPTER VII \\ HISTORICAL REFERENCES TO DOGS OF PEKINGESE TYPE}

T T has been suggested by some that the type of dog known among Europeans as the "Pekingese" has existed in 1 China from a very early period as a distinct race having essentially the points now characterizing it. Others argue that it is only within the last two hundred years that the type closely resembling the modern "Pekingese" has been evolved. Study of such information as it has been possible to collect will leave a decision with the reader's own judgment.

About 500 years B.C. it is recorded that dogs were used in the kingdom now represented by the Province of Shansi, for sporting purposes. Some of these were probably small dogs, for it is mentioned that after the day's sport one kind of dog followed its master's chariot, while "those having short mouths were carried in the carts."

It was only at the end of the first century of our era that the Chinese books become a little more specific as to the nature of the dogs mentioned. They speak of some of them as being called by the name "Pai," which later Chinese authorities explain as referring to a very small "shortlegged" and "short-headed " type of dog "which belongs under the table." The Chinese table of the period was low, and those round it sat on mats.

It will be seen later that some ancestors at least of the 


\section{DOGS OF CHINA AND JAPAN}

modern "Pekingese" dog came from Europe. In evidence of the fact that communication with Europe existed at an early period it may here be mentioned that the name "China" is probably due to the country's becoming known to the Græco-Roman world during the Ts'in Dynasty (255-206 B.C.) about the time of Ptolemy (247-222 B.C.). A little later silk was introduced into Rome and Greece by the northern overland route. This overland caravan route became thoroughly established during the Han Dynasty, a hundred years before the Christian era. The profusion of silks which were worn by the wealthy Romans all came from the looms of Han in exchange for the products of the West, chiefly glass, steel, pottery, elephants, horses, and most probably, in view of the custom of including them as objects of exchange between states even at this early period, the pet dogs for which the Eastern Roman Empire and Greece were famous.

With the death of Ling Ti the Eastern Han Kingdom, which constituted China, broke up into three parts. These united for a short period only to be split into sixteen minor kingdoms which waged war among themselves for a period lasting roughly from A.D. 300-400. No less than six dynasties rose and fell before Buddhism introduced into China at the beginning of the first century B.C., became the dominating religion.

"By the year 420 of our era a decisive change was wrought for China, full of the most important consequences for the future of her literature and art ; and that was a clear division of the groups of Chinese states into North and South Dynasties - the whole north, the ancestral seats, being taken over by Tartar conquerors.

The Emperors of pure Chinese stock now moved their capital down to the lately civilized south. This separation, with relatively long intervals of peace between the two 


\section{HISTORICAL REFERENCES TO PEKINGESE TYPE}

sections, lasted nearly two centuries, down to A.D. 589-605, when the reunion of China was cemented under Yang Ti. In these two full centuries Chinese culture, including poetry and art, was entirely recreated." *

After the almost simultaneous blotting out of the Roman and Han Empires, the Tartars and Huns largely blocked the trade-route and cut off peaceful traffic to a period as late as the middle of the fifth century of our era. Communications then for a second time became possible up to the end of the T'ang Dynasty (A.D. 907), when they were again disjointed by the spread of Islam, which no doubt interfered with ambassadorial and trading missions to China, but did not necessarily completely interrupt exchange of dogs. Islam, it is true, classes dogs as unclean, but Katmir, the watchdog, was admitted to heaven by Mohammed for guarding the Seven Sleepers. The Turks were not averse to presents of rare canine specimens. In the seventeenth century they succoured starving dogs and used dogs for hunting. The women, too, prized and reared Maltese dogs. The Venetian Ambassador in Constantinople wrote to the Doge and Senate in I 583 that the Ambassador of Queen Elizabeth of England, " in spite of all the opposition offered to him by the French Ambassador, has this morning kissed the Sultan's hands. He has presented His Majesty with a most beautiful watch set with jewels and pearls, two pretty lap-dogs, thirteen pieces of silver gilt. ..." † In I594 he wrote that " two great sporting dogs "were requested of the Venetian Government in the Sultan's name. The Doge and Senate appear to have had difficulty in satisfying the Sultan, for in 1607 the Venetian Ambassador at the English Court wrote that he would execute the order of His Serenity the Doge to buy "two big

* Fenollosa, "Epochs in Chinese and Japanese Art," vol. i, p. 35.

† "Calendar of State Papers. Venice." 


\section{DOGS OF CHINA AND JAPAN}

fierce dogs " to be sent to Constantinople as a present from the Venetian Government to the Turk. He sent them in 1609 .

Against the Emperor Kao Wei, of the Northern Chi Dynasty, who reigned $565-577$, and with Ling $\mathrm{Ti}$ and a few others known to the Chinese as the Madcap Monarchs, it is recorded :

"In 565 A.D. the Emperor gave the name of Ch'ih $\mathrm{Hu}$ or 'red tiger' to a certain Persian dog. He also gave it the rank and privileges of Chun Chun (closely allied to those of a duke). The dog was fed with the choicest meat and rice. It was granted the revenue of a Prefecture. When the Emperor was mounted the dog rode upon a mat placed in front of the saddle." *

The Persian dog referred to must have been small to have been able to ride on a mat in front of its master's saddle. The others were very possibly sporting dogs, for it must be remembered that this monarch's inordinate love of the chase lost him both his kingdom and his life. It happened in this way :

"The Emperor, accompanied by a favourite concubine, left Ping Yang for Hsinchow in Shansi on a hunting expedition. During his absence, troops from Peichow attacked Ping Yang. Three successive messengers were sent in hot haste to ask for reinforcements, but the Secretary of State reproved them all for wishing to interrupt the monarch's sport. The Emperor was hunting one evening, and had just killed when a fourth messenger brought him the news that Ping Yang had fallen. Kao Wei was then minded to go back immediately, but his concubine successfully implored him to make one more drive. Upon his return he collected a great army, surrounded Ping Yang and endeavoured, by day and by

* San Kuo Tien Lueh of the T'ang Dynasty. 
FROM AN IMPERIAL DOG SCROLL

PAINTED BY MIAO SU-CHIÜN, INSTRUCTRESS IN PAINTING TO THE LATE EMPRESS DOWAGER, DATED SEPTEMBER I 890
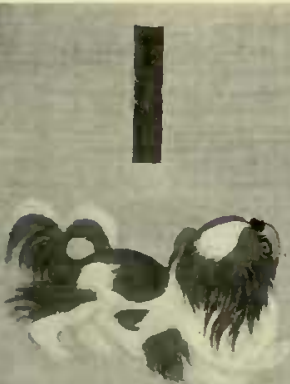

NO. I. LI-ERH (PEAR). LONG-COATED HAH-PAH DOG.

Length of Body, I ft. 5 in. Height 8 in. Sent from Thibet as a present to the "Emperos. Its temperament is that of a human being

NO. 2 SHIH-LIU (POMEGRANATE), LO-SZE DOG. Length of Body 1 ft. 5 in. Height 8.5 in.

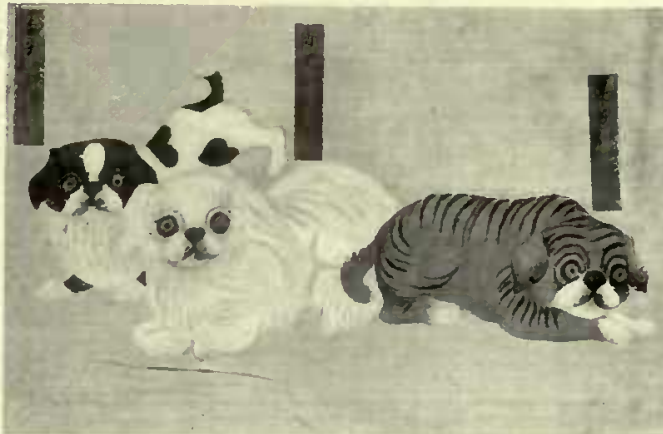

67

NO. 3. CHIEH-TZU (LUCKY). LO-SZE DOG.

Length of Body $1 \mathrm{ft} .3$ in. Height 6.8 in.

NO . 4. HSIANG-ERH (FRAGRANT). HAF-PAH DOG

Length of Body $1 \mathrm{ft} .6 \mathrm{in.}$ Height $7.5 \mathrm{in}$.

NO 5. TA-TZU (MONGOL). TIGER-HEAD LO-SZEDOG Height of Body $1 \mathrm{ft} .7 \mathrm{in}$. Height $8 \mathrm{in}$.

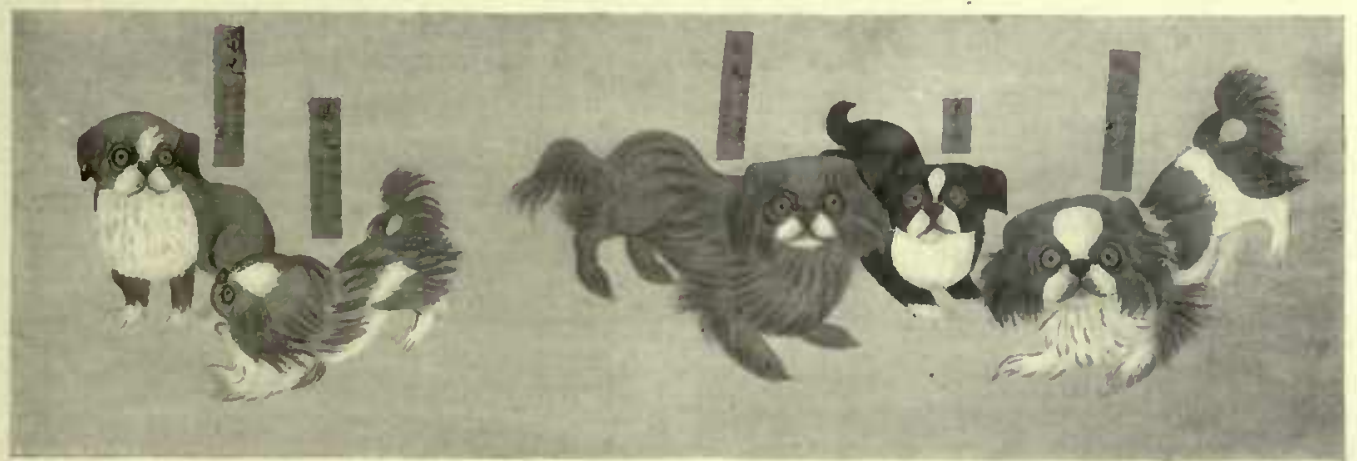

NO. 6. PAO-ERH (PRECIOUS). LO-SZE DOG. Length of Body $1 \mathrm{ft} .4 \mathrm{in}$. Height $6.5 \mathrm{in.}$

NO. 7. CH'OU-ERH (SMELL) HAF-PAH DOG. Length of Body 1 ft. 7 in. Height 6.7 in.
NO. 8. HSING-ERH (APRICOT). HAH-PAH DOG. Length of Body 1 ft. 6 in. "Mother cross-bred." NO. 9. MO-HAI (INKSTAND) LO-SZE DOG.

NO. IO. P'ING-ERH (BOT'TLE) HAH-PAH DOG.

Length of Body i ft. 8.5 in. Height 8.5 in.

11

12
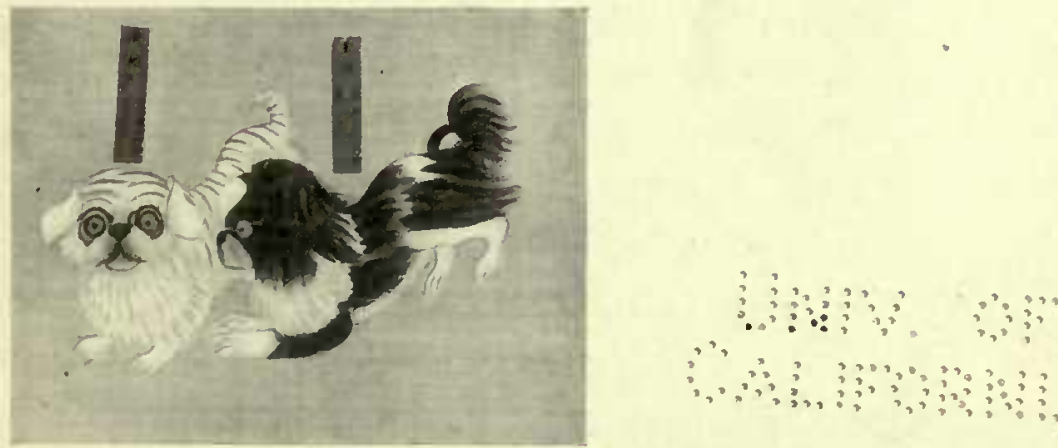

NO. II. T'AO-ERH (PEACH). STRIPED LO-SZE DOG. Length of Body ift. 6 in. Height 7.9 in. Come from Heilingkiang.
NO, I2. YU-TING (JADE BUTTON), HAH-PAH DOG. Length of body $1 \mathrm{ft} .5 \mathrm{in}$. Heipht 8 in. 
$\because \because \quad \because \because \vdots \vdots \vdots \vdots 90$

\begin{tabular}{c}
0 \\
\hdashline \\
\hdashline
\end{tabular} 


\section{HISTORICAL REFERENCES TO PEKINGESE TYPE}

night, to storm it. His soldiers tunnelled beneath the walls of the city and a part of it fell to the ground, leaving a great breach easy to be stormed. The Imperial officers urged a general assault, but the Emperor ordered them to wait for the arrival of his favourite. The preparation of her toilet, however, caused such delay that the defenders were enabled to barricade the breach with beams. A few days later the Emperor, accompanied by this concubine and his ministers, was watching a minor engagement, which finally turned against his troops, with the result that the lady, being stricken with panic, counselled flight. Her fears communicated themselves to the ministers and also to the monarch himself. Notwithstanding his great superiority of troops, the Emperor fled-first to Taiyuenfu and then to his capital, Changtefu. These in turn fell into the hands of the pursuing enemy, and, fleeing towards the Province of Shantung, the defeated Emperor was caught half way. Finally, together with his concubine, he was executed." *

References to pet dogs are numerous in the T'ang history :

"The Emperor of the Turkoman country visited the Honan Emperor in 609 and accompanied the Emperor Yang Ti on an expedition to Korea. He married a Chinese princess on his return. His successor sent an envoy with two dogs, one male and one female, to the Emperor Kou Tzu (6r8-629). Their height was about 6 tsun (inches), and their length 1 ch'ih (foot) and a little. $\dagger$ These dogs were of great intelligence. They could lead horses by the reins, and each was trained to light its master's path at night by carrying a torch in its mouth. These dogs were born in the Fu Lin country." $\ddagger$

- Yu P'i T'ung Chien.

† This was probably the Chinese builder's scale. On this scale one Chinese foot of ro Chinese inches is equal to $12 \frac{1}{2}$ British inches. These dogs were therefore $7 \frac{1}{2}$ inches high and $12 \frac{1}{2}$ inches long.

† T'ung K'ao, by Ma Tuan Lin (lived about A.D. 960, in Sung Dynasty), and T'ung Tien by Tu Yo. 


\section{DOGS OF CHINA AND JAPAN}

The name Fu Lin, also read Fo Lin, may or may not be the Chinese transliteration of eis $\tau \dot{\eta} \nu$ mód $\iota \nu$, said to be the origin of the name Stambul, but these dogs certainly came from the West, and there is little doubt that Byzantium, now Constantinople, the Eastern capital of the Roman Empire, was designated by the word.*

The last distinct record of a communication from the Byzantine Empire is found in A.D. 1371 under the Emperor Hung $\mathrm{Wu}$. It is interesting to note that by this time the Chinese capital was definitely fixed at Peking, but that up to the middle of the seventeenth century the Chinese literati continued to call the small Imperial dogs by the generic name of "Dogs of Fu Lin." Modern research has shown that the silk trade between the Eastern Roman or Byzantine Empire and China was considered to be of very considerable importance by the Courts of both China and the West, as well as by the Turks and other fluctuating peoples through whose country the trade passed. In 719 there arrived in China an embassy from $\mathrm{Fu}$ Lin bringing lions and spiralhorned sheep. The Byzantine Emperor at this time was Leo the Isaurian. There are definite records of at least seven direct embassies from $\mathrm{Fu}$ Lin to China between the years A.D. 600 and 1400 . Seeing that the powerful T'ang monarchs, whose empire in the case of T'ai Tsung stretched westward to the Caspian, displayed great interest in the Fu Lin breed of dogs, it would not be surprising if later research were to demonstrate that numerous specimens of the breed were imported to Hsianfu, the T'ang capital, direct from Byzantium.

The success of the Mohammedans interfered with, and possibly put an end to the Byzantine trade which had been

" "Cathay and the Way Thither," Yule, vol. i, p. 44 ; and Bushell, "Chinese Art," p. 73 .

128 

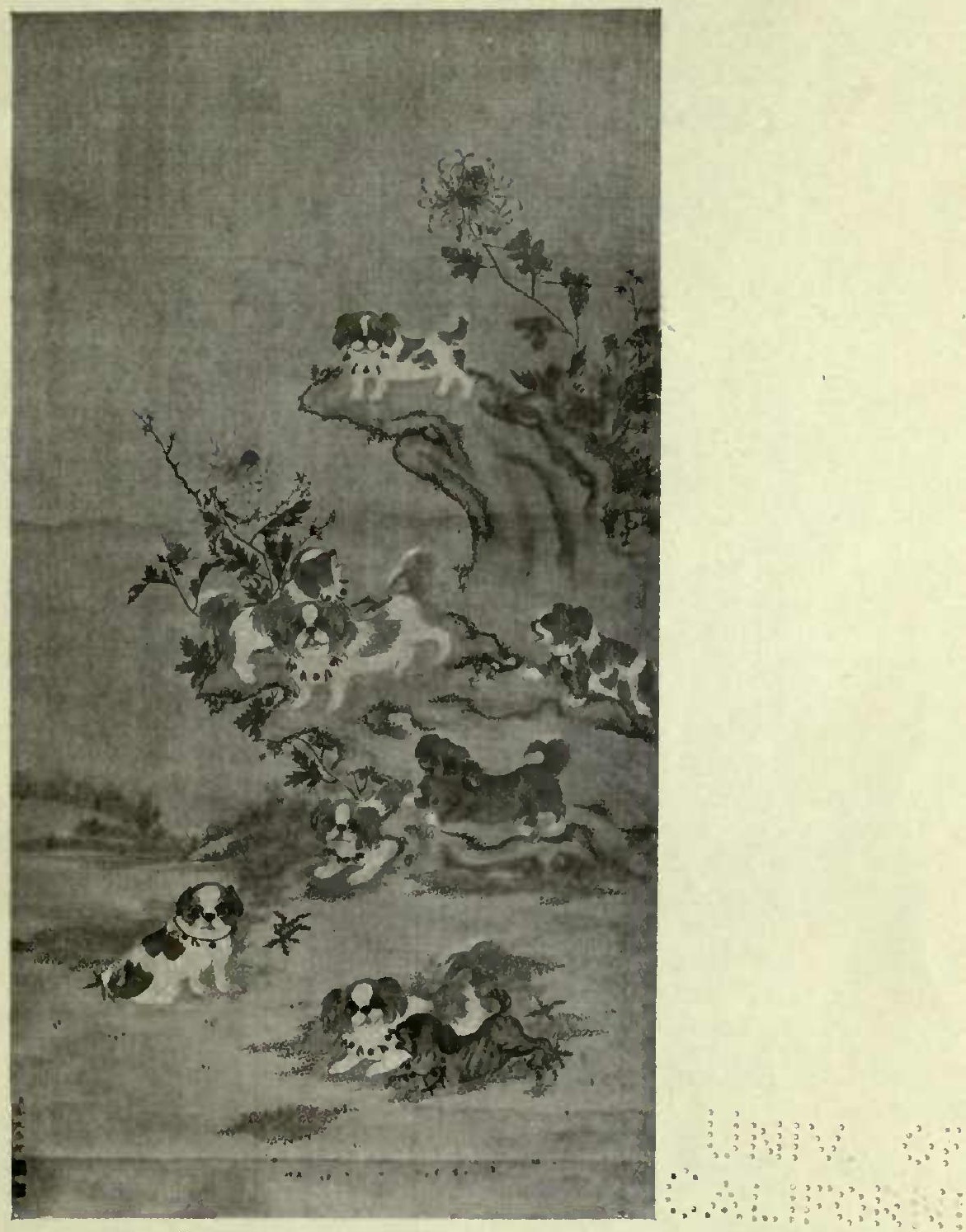

SIGNED : " RESPECTFULLY PRESENTED. LENG MEI.

CAREFULLY PAINTED." K'ANG HSÜ PERIOD

(AUTHOR'S COLIECTION) 



\section{HISTORICAL REFERENCES TO PEKINGESE TYPE}

carried on for a long period over a land route, through deserts and over mountains, requiring a journey of two years through the heart of Asia. Silk and other valuable merchandise may have filtered through after the Arab conquests, but as the canine race is unclean to the Mohammedan, it appears less likely that dogs were sent as presents to China from $\mathrm{Fu}$ Lin after its capture by the Arabs.

The fact that shortness of nose is not recorded as a special characteristic of these dogs appears to indicate that they were remarkable for their small size and intelligence rather than for other special characteristics. Early writers refer to the remarkable small Maltese pet dogs from Zapuntello and Malta as being an article of export throughout the Near East. This fact makes it more than possible that $\mathrm{Fu}$ Lin dogs were of the "Maltese" race, but whether, in these early days, there were two or three varieties as described in A.D. I755, "short-haired or long-haired or maned," * and " in size resembling the ordinary weasel," is of course unknown.

Comparison of the Japanese and Pekingese races at early periods should throw light upon the nature of the small dogs of the time, for, if both the modern "Pekingese" and "Japanese" dogs are derived from the same ancestral stock of this period, and if there has been little subsequent crossing of the breeds, their ancestor must then have closely resembled these two present-day races.

We now reach one of the most famous references to small dogs in Chinese history. It is recorded that the Emperor Ming of the T'ang Dynasty, who ruled from A.D. 713-755, had a favourite wife named Yang Kwei Fei, whose beauty is historic. It happened one day that the Emperor was playing

"Johnston's " Elian "; " Toy Dogs and their Ancestors," by the Hon. Mrs. Neville Lytton, p. 30. 


\section{DOGS OF CHINA AND JAPAN}

at chess with a certain prince. Perceiving that her Imperial master was certain to suffer the indignity of defeat, his wife, who was an interested spectator, contrived to loose her pet dog upon the board, so that the pieces were upset and the game ruined, to the great delight of the Emperor. This dog was white* in colour, and was named "Wo" (pronounced Waugh). It came from the K'ang country, one of the nine kingdoms founded by the Emperor Wen in the Pamirs.

Possibly the famous poet Yuan Wei Ch'ih of this period was referring to this dog when he wrote the couplet quoted in $\mathrm{K}$ 'ang Hsi's dictionary :

How fierce is proud Wo,

Though still in his slumbers.

The Emperor K'ang Hsi's dictionary refers to the character "Wo," and states that this name was applied to a race of small dogs. The name was probably in general use towards the close of the T'ang Dynasty.

The first occasion on which the Ssuchuan "pai " $\ddagger$ pro-

- Stated to have been white in one only of many references.

t "Kuang Shih Lai Fu," by Ho Hsi Min.

I Bai Dog. The oldest generic name for small dogs is " pai," pronounced in the ancient dialect of Shansi approximately "bye." It is recorded from the Han dynasty, 100-200 B.C. The mongol name for pet dogs is No-hai. The Thibetan is Chi-choong.

The famous dictionary compiled under the Emperor K'ang Hsi (A.D. I662-I723) quotes two old encyclopædias as considering the word " pai " to refer to :

(I) A dog with short legs. Quotation from the "Shuo Wen." Han Dynasty. About A.D. 150 .

(2) A dog with a short head. Quotation from the " Kwang Yun," Sung Dynasty. About A.D. I000. This authority states that the above character was also pronounced "p'ai "-pronounced pie in English.

(3) An under-table dog. "Kwang Yun," Sung Dynasty. A.D. 1000. This authority also states that "bai " refers to a "short-headed" dog.

High tables have been used in China for about 1000 years only. This quotation makes reference to small tables similar to those whose use survives in Japan to the present day; so that the writers may be taken to mean that "bai " refers to a race of small dogs which were generally short-legged as well as "short-headed."

It will therefore be noted that the character referred to a short-legged dog from, at 


\section{HISTORICAL REFERENCES TO PEKINGESE TYPE}

nounced "bai") dog, which became commonly known as the "Lo-Chiang" dog, is mentioned in Chinese literature is that on which the Hsin Lo State of Korea sent as tribute to Japan in A.D. 732, " one parrot, one thrush, one Ssuchuan 'pai' dog, one hunting dog," and other animals.* Lo-chiang (or Lo-kiang) is a sub-prefecture in Nienchow, about thirty miles north of Chengtu, the provincial capital of Ssuchuan.

The Lo-chiang dog appears to have remained in fashion for three centuries, and one became very famous under the Sung Dynasty.

"In the reign of Hsi Tsoong (874-889) of the T'ang Dynasty, a member of the Council of State named Wang To owned a very " short-legged" (p'ei-chiao) dog named Hua-ya (flowery duck). One night an assassin broke into his house through the roof, but, being discovered by the dog, was frustrated." $\dagger$

This reference marks the break-up of the T'ang Dynasty, latest, A.D. I50; from about A.D. I000, at latest, it certainly referred to "shortheaded," "short-legged," "under-table," small dogs which may have been of different breeds.

The commonest generic name found in Chinese writings is " the dogs of Fu Lin." It appears certain, however, that though this name persisted as a classical term used by scholars up to the beginning of the Manchu Dynasty, it has long ceased to be the common spoken name. The name may even have been purely literary, and never used outside the writings of the scholars. Chinese who are interested in pet dogs now always use the term "ba-erh" dog, and less commonly " hah-bah" dog as the generic term. When using the colloquial term Chinese writers appear to have endeavoured rather to represent the sounds for the common names in use, than to establish a fixed generic character.

It seems probable that the old "bai-rh" survives in the present word " bah-rh." It may be noted here that generic names are usually monosyllabic among the Chinese, and would naturally tend to remain so. Any lengthening of the name would be likely to have a descriptive or qualificative meaning. The Chinese written character representing the sound would very naturally vary because the Chinese have never given to the canine race the importance with which it is regarded by the European. Consequently the references in Chinese literature to the "bah-rh" dog(which was written by the scholars "Fu-Lin dog") were probably so rare that a writer would invent a character for the Jatter name.

* "Hsï Jih-pen Chi."

t "Yuan Chien Lei Han." 


\section{DOGS OF CHINA AND JAPAN}

the second in Chinese history of the five periods of peace which allowed literature and art to flourish. For half a century the country was torn by internal strife, which resulted in the establishment of five successive dynasties, each lasting for not more than ten years, and each ready, if occasion offered, to change its capital city from Hsianfu, the T'ang metropolis. In 969 these warring dynasties gave place to the great Sung Dynasty, which, for nearly two hundred years, ruled in peace in both North and South China, and still continued to rule for another hundred years, at its Hangchow capital in South China, while desperately fighting in the North with the Mongols, who finally overthrew it.

"About the year A.D. 990 an official in Ssuchuan gave the Emperor T'ai Tsung of the Sung Dynasty a Lo-chiang dog named T'ao Hua (peach flower) from Ho-chow (about fifty miles north of Chungking). It was extremely small and very intelligent. It followed the Emperor everywhere. When there was an audience the dog preceded him, and by its bark announced its Imperial master's arrival. When the Emperor T'ai Tsung was ill it refused to eat. When the Emperor died the dog manifested its sorrow with tears and whining. The palace eunuchs endeavoured to train the dog to precede the new Emperor, but without success. The Emperor caused to be made an iron cage with white cushions in sign of mourning, and this, containing the dog, was carried in the Imperial chair to his master's tomb. There the dog died, and the Emperor Chen Tsung (a faithful disciple true to the Confucian doctrine) issued a decree ordering it to be wrapped in the cloth of an Imperial umbrella and buried alongside of its master." *

The historical record from which this reference is taken - "Yuan Chien Lei Han," vol. cxxxvi. 


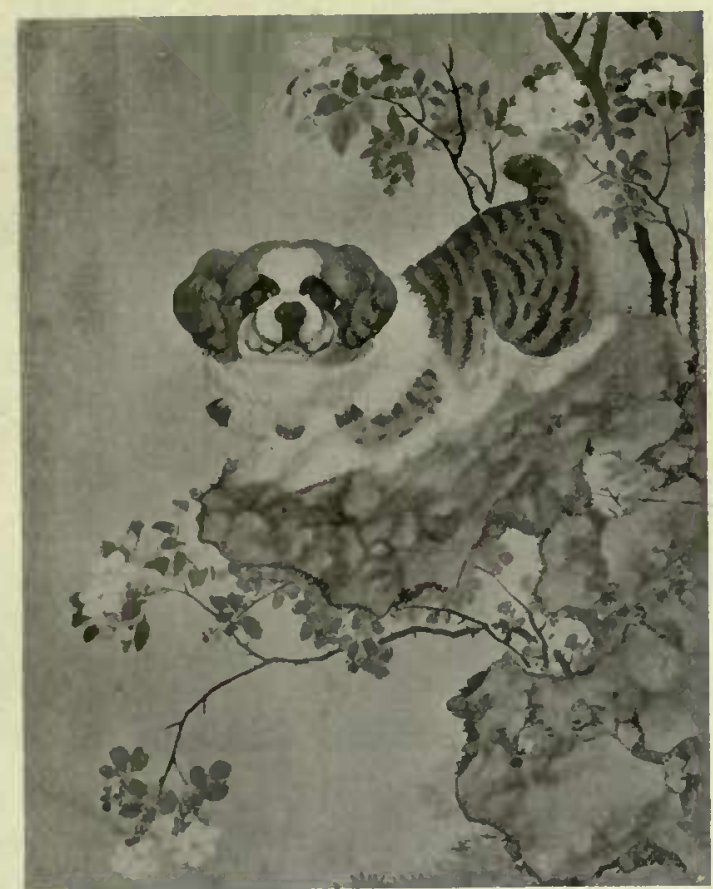

SHORT-COITED " PEKINGESE," MODERN



BACK OF CHINESE HAND-MIRROR. TAO KUANG PERIOD (ABOUT I 850). PAINTED ON SILK

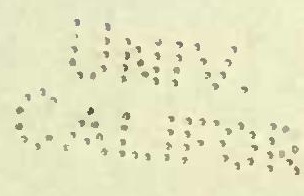


4

क 


\section{HISTORICAL REFERENCES TO PEIKINGESE TYPE}

proceeds to quote in honour of this dog two long odes written by $\mathrm{Li}$ Chih, a famous poet of the period.

About the year A.D. I04I, in the reign of the Emperor Ren Tsung of the same dynasty, the soldiers in the Imperial palace became mutinous. The Emperor, who was in one of the houses of the palace, was much frightened by the uproar. A certain censor, perhaps remembering the story of T'ai Tsung's dog, memorialized him as follows: "In Ssuchuan there is a place named Lo-chiang famous for its dogs. Search should be made for one of these having a red coat and a short tail. Such as these are very quick of ear and should be bred in the palace so as to give early warning of trouble outside." The enemies of this censor, whose name was Sung, nicknamed him "Sung Lo-chiang" for having given the Emperor this advice.*

No special breed of small dogs has existed at Lo-chiang in modern times, and the present customary name for small pet dogs in Ssuchuan is said to be "Peking" dog. In view of the fact that -sze is a common suffix to Ssuchuan place-names, it appears possible that an old name, Lo-chiang-sze, has been contracted into Lo-sze, which is the common name in Peking for the short-haired pug breed. It therefore appears possible that the Lo-chiang dog, so famous in Chinese history, was in reality practically identical with the English pug, which is known to be descended from Chinese ancestors.

History records that the Emperor K'ang Hsi's study at Peking was ornamented by three pictures catalogued as " Rocks, cat and dog," "Dogs in play," "Cats and dogs." Apparently these represented small pet dogs, possibly of the Lo-chiang breed, for the pictures were painted by a native of Ssuchuan, and almost certainly for an Emperor

- "Yuan Chien Lei Han," vol. cxxxvi. The nickname cannot be accurately translated, but an approximate rendering may be "Pug-dog Sung." 


\section{DOGS OF CHINA AND JAPAN}

reigning at Chengtu during the period of the five dynasties907-960.*

During the Yuan Dynasty (1206-1333), the Mongol Emperors, following the example set them by Assyrian monarchs two thousand years previously, prided themselves on their menageries, and Marco Polo records that lions roamed the courts of the Peking palace.

"It was the custom of the Emperors on the days when they give feasts in honour of the Princes and High Officials to take out at the Ten Thousand Years' Hill (the Coal Hill) all the beasts-tigers, leopards, bears, elephants-parading them one by one before the guests. After these were brought the lions. These beasts are small and short in body. They are astonishingly like the 'golden-coated, nimble dogs' which are commonly bred by people themselves in their own homes. All animals, when they see the lions, are terrified. Their anger is more fearsome than that of all other beasts." +

It is just possible that some of these "golden-coated nimble dogs" were introduced into Europe during this period, for, during the latter part of the Yuan Dynasty, Chinese princes were received by the papal court at Rome, and Franciscan missionaries had established some forty bishoprics in the Celestial Kingdom. Marco Polo visited China, saw Hangchow, and left us the one account of medixval China that is at all trustworthy. Christianity had probably penetrated China at a much earlier period. Nestorian bishops are known to have been appointed in the first quarter of the eighth century.I

A further reference to a "golden-coated" dog probably belongs to this period. A Chinese chronicler says : "There

" "Pei Wai Chai Shu Hua P'u," vols. xcv-c.

t " Jih Hsia Chiu Wen K'ao," Chuo Keng Lu.

f "Cathay and the Way Thither," Yule, vol. i, p. I03. 
was a civilian named Shen Heng Chi who bred a 'Chin Ssu' (lit. golden-silk) dog in his home. This dog was not more than one foot long, and was very intelligent. When guests were presented the dog lay beneath the table. After the dog had been reared for three years the owner fell ill. The dog in sympathy refused to eat. After a few days the master died. The dog showed signs of excessive grief when the corpse was put in the coffin. The coffin was kept in the home for one year, during which time the dog always lay beneath it. When the corpse was being removed for burial the dog beat its head with such violence against the coffin that it died."

After the overthrow of the degenerate line of Kublai Khan in 1368 , no European penetrated into China for nearly two hundred years. The cult of the race of pet dogs seems to have fluctuated with the interest taken in the breed by the Emperors. During the Ming Dynasty (1368-1628), there is no mention of kennels in the list of Imperial stables, etc., and it seems probable that pet dogs were altogether out of fashion. The Sons of Heaven appear to have interested themselves specially in cat-breeding, a hobby against which, in England, there was a prejudice during the Middle Ages, as cats were associated in the popular imagination with witchery and other diabolical agencies. Some of the Chinese Emperors carried their enthusiasm for cats to remarkable excess, for the eunuch Liu Jou Yii, writing his reminiscences under the last three Mings, puts on record that "There are three or four men, body-servants of the Emperor, whose special business is the feeding of those cats which have official rank or are famous. Upon all of these cats the Emperors have bestowed their affections one above the other. Awaiting the Emperor's grant of names and official rank ordinary male cats are called pages, while emasculated cats are called 'old 


\section{DOGS OF CHINA AND JAPAN}

father,' the analogue for the female being 'old maid.' The pay given to the eunuchs for upkeep of each cat is according to its rank. So noisy are the cats that all the Emperor's sons and daughters at childhood are continually brought to sickness, even unto death ; and who is there that dares to complain ? If there had been some places near the dwelling-house in which the cats could have been confined it would have been a good thing. We have heard that, because their sons and grandsons grew up in the palace under nurses, and loving only one wife, do not realize the importance of the rearing of children and of obtaining sons, the Imperial ancestors bred cats and pigeons. Over the doors also they hung snake characters, pictures of 1000 boys and the hundred sons, so that when the Emperor should see the inscriptions and the rearing of the cats and pigeons there might be brought to his attention the importance of the rearing of numerous children." *

Dr. Macgowan, arguing from the facts that cats are not included among the six domestic animals recorded by the early Chinese nor among the zodiacal constellations, suggests that the cat was domesticated at a late period in China. Yuen-chuang, the pilgrim monk who in the seventh century A.D. returned after sixteen years' wandering in India, brought cats with him to protect his collection of Sanskrit Buddhist books from rat-gnawing. That account, supposedly of the first introduction of cats, is, however, somewhat undermined by the following anecdote of Confucius: "Tseng Shen and Min Tzu, canonized disciples of the Sage, were listening outside to the music of the Master, who, as was his wont, was soothing himself by the lute that he loved so well, when suddenly the strain was changed. On entering and inquiring what the change meant they were told by Confucius that he had seen a cat making for a rat, and that he had struck up

- Ming Kung Shih, "Palace Affairs of the Ming Dynasty," vol. ii. 


\section{HISTORICAL REFERENCES TO PEKINGESE TYPE}

another tune to stimulate the cat in its attack upon the rodent." *

These conflicting statements are from authoritative sources, and it is impossible to offer a satisfactory explanation, remarks Macgowan. He holds that the cat was brought to East Asia from the West. The animal is named but twice in all the long periods of early Chinese history, and as a domesticated animal only once. Possibly the cat of Confucian times was a wild cat only partially domesticated.

Cats appear to have continued to be the favourite pets of the Chinese court ladies to the end of the Ming period, but soon perhaps gave place to the small breeds of dogs. In 1655, soon after passing Lin-ching on the Grand Canal, John Nieuhoff wrote :

"In this Province [about Peking] are white rough cats, not unlike the Malteeza Dogs, with long ears, which are there the ladies' joysting hounds or play-fellows; they will catch no mice, being too much made of." $\dagger$

Linchinchow is still well-known in China for its white cats having eyes of different colours. It may have been the home of the " white cat of a rare species brought from Asia, whose eyes were of different colours, the right yellow as a topaz, the left blue as sapphire," which was provided by Leonardo da Vinci for the amusement of Monna Lisa del Gioconda when painting her portrait, $1503-1506 . t$

Athanasius Kircher, $\S$ when describing the custom of footbinding among the Chinese ladies, is translated, "Others say that this co-ercitation was enacted by a law of the wise men, that women may learn to sit at home, which if they do not voluntarily, they are by this means compelled. Their habit

" "Cats," China Br. R.A.S., x89r, p. $x 28$.

† John Ogilby's "Embassy from the East India Company," p. 105, r669.

I "Roman de Leonard de Vinci," J. Sorreze.

$\S$ John Ogilby's " Embassy from the East India Company," p. 70. 


\section{DOGS OF CHINA AND JAPAN}

is modest and full of gravity, being veiled so that no part is naked except the face: they adorn their heads, especially the more noble sort (and those that live at Court) with divers wreaths and fillets beset with precious stones, which add a wonderful splendour. Their vests interwoven with flowers, birds, and the like ornaments, trail at their feet, but yet so that what they esteem their chief beauty is not obscured, and to pass away their time, they sport with little dogs, ${ }^{*}$ birds, and such delights."

The breeding of dogs within the precincts of the Imperial Ancestral Temple was prohibited. Under the Emperor Wan $\mathrm{Li}(1563-1620)$, in spite of this prohibition, a certain eunuch named $\mathrm{Tu}$ secretly kept a small hai-bah $\dagger$ or hsieh-bah

"The French version reads " cats.'

† Hai-Bah (or Ai-Bah) Dog. The name " bai " is found lengthened by either of the three characters " ai," " hai," or "hah." Of these " ai " and " hai " appear first in the Ming period, during which the generic name was " hai-pah " or " ai-pah." The character used for " ai " means " short." That for " hai " in the Ming word " haipah" dog was either a character meaning " sea "-all lions and mythical monsters are even now considered by superstitious Chinese to belong to the sea-or one meaning "unicorn," an animal often confounded with the Buddhist lion. The dragon-world underneath the sea is part of primitive Chinese mythology, and the Chinese spirit-lion was classed as one of the fabled nine dragon children. The lionunicorn or "hsieh-chai " is found embroidered on the robes of censors and judges, and indicates the fifth grade of official rank. The "hsieh-chai" is also found, but very rarely, in place of the lions outside a Buddhist temple. In Shantung the name for the small faience dogs (the origin of which is anterior to the introduction of Buddhism into China) which guard the corners of all important roofs against fire, is " hai-bah " dog -literally "-sea small dogs."

The term "hah-bah" dog does not appear previous to the Ching or Manchu Dynasty. The Manchu name for the small dog species is "Kha-per-i," pronounced ha-per-i. Laufer considers the term " hah-pah " to be of Turkish origin. It seems not unlikely that the Manchu influence has brought about the use of a word confounding ha-per-i and hai-bah-rh, and modifying each to the name "hah-bah-rh" which means, in colloquial Peking dialect, " to limp, to roll in the walk." This word would, to the uneducated Chinese, have some sort of meaning applicable to the slightly rolling gait encouraged in the Pekingese breed, while the word " hai-bah " or "Kha-per-i " would convey little, or no meaning whatsoever.

There appears to be little doubt, although there are no written records on the point, that the commonest vernacular name in the Tao Kuang period was "bah-rh," dog. This appears certain from the testimony of living witnesses and from the 


\section{HISTORICAL REFERENCES TO PEKINGESE TYPE}

[lit. " unicorn "-_" scratch" or " scramble "] dog to which he was attached. This came to the knowledge of a certain chief eunuch of the Board of Punishments well-known for his relentless severity. He threatened to inform the Emperor of this crime, but was dissuaded by a douceur of something over 1000 taels in silver.

It was during the Ming period that modern European traders first entered into trade relations with the Chinese Empire-the Portuguese in 1516 , the Spanish from the Philippines in 1575 , the Dutch in 1604 , and the English in the dying days of the dynasty in 1637 ; the Portuguese traded solely at Canton, the Spanish permitted the Chinese to trade with them at Manila, and the Dutch and English traded at first at Amoy and in Formosa.

From as early as the Sung Dynasty direct foreign trade with the Chinese capitals had been but slight. Merchant caravans from the seven or eight kingdoms on the western frontier of China were allowed in under pretence of being ambassadors bearing tribute to the Chinese Emperors. They brought public letters forged in the names of the sovereigns they professed to represent, with jade, diamonds and similar merchandise suitable for such arduous overland transport. In exchange they received lavish entertainment and presents far exceeding the value of their own. The Jesuit records of occurrence of eight dogs in certain illustrations of the breed-a pictorial pun on the Chinese word for "eight" which has the same sound, "bah-rh."

The Chinese are so weak in exact definitions and scientific distinctions, that it difficult to decide the question as to whether "bah-rh" or " hah-bah" has the wider significance at the present time. Both terms are commonly used in Peking to denote any small pet dog of any breed, Chinese or foreign ; but the Chinese readily use the words "Shih-ze" or "Lo-sze " as qualificative of the " ba-erh" dog, meaning "lion" or "pug" small dog; yet they refuse similarly to qualify the "hah-bah" dog. This appears to indicate that the "bah-rh" dog is the broad stock from which the Chinese consider the lion dog and the pug dog to be minor offshoots, while the term " hahbah " may be taken to comprise what is probably an amalgamation of several varieties, which were probably fairly distinct in the Tao Kuang period and are now roughly comprehended in the English breed named "Pekingese." 


\section{DOGS OF CHINA AND JAPAN}

the early part of the seventeenth century refer to these sham embassies, and state that " the Chinese themselves are quite aware of the imposture, but they allow their Emperor to be befooled in this manner as if to persuade him that the whole world is tributary to the Chinese Empire." *

There is said to be a record in the Peking palace archives to the effect that during the reign of $\mathrm{K}$ 'ang Hsi ( $1662-1723$ ) or Ch'ien Lung, a high official named Fu sent a "Chin Mao Shih Tzu " (golden-coated lion-dog) to the Emperor. Kircher, writing about 1667 , figures the monarch of the "ChinaTartarian Empire," who must have been K'ang Hsi, and a short-coated dog of spaniel size having a long nose and straight legs. The dog wears a collar with bells, and has a ring, with a bell attached, through its ear. $\uparrow$

Forty-two years later Peter the Great sent an embassy to the court of the Emperor K'ang Hsi. It was received with greater honour than has been shown to any other embassy before or since. In its records we read that on its arrival, by the land route, at Peking an envoy was sent by the Chinese Emperor to welcome the Ambassador. "The aleggada remained for the space of three hours, talking on different subjects. The minister, it seems, was a great sportsman. $\mathrm{He}$ asked to see the ambassador's dogs, which were a few greyhounds and some French buckhounds. He was desired to receive, in a present, any of them which pleased him best but he would accept only a couple of greyhounds."

November 29. "The ambassador at the same time delivered to the Mandarin, as a present from himself to the Emperor, several toys of value, a fine managed horse, some greyhounds and large buckhounds.

"Everything was entered in a book very exactly, even the "Cathay and the Way Thither," vol. iv, p. 243.

f Figured in both John Ogilby's and the French translations. 

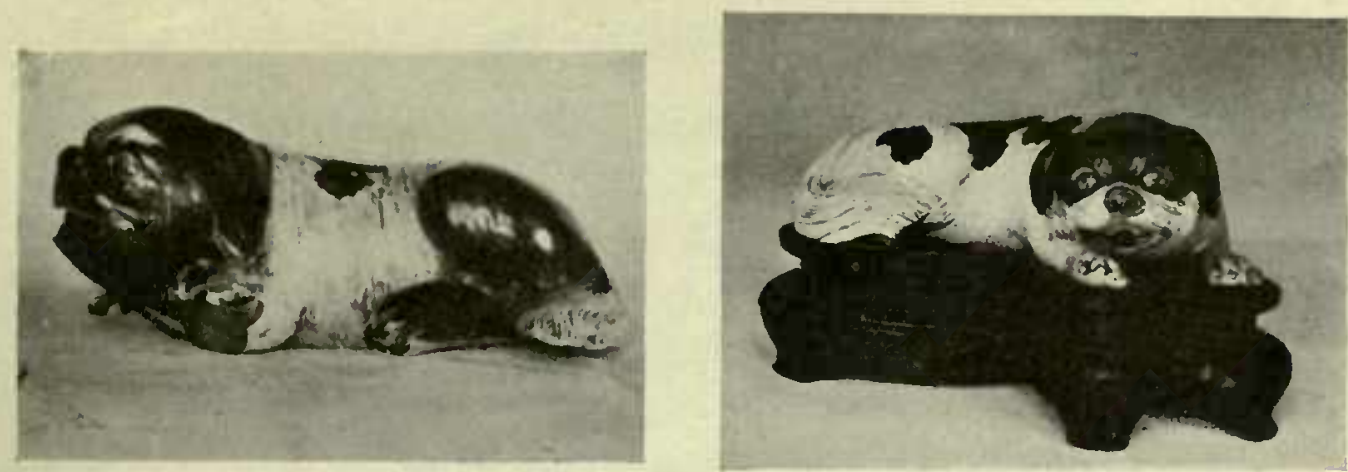

PORCELAIN DOGS FROM PEKING. TAO KUANG PERIOD (AUTHOR'S COLLECTION)

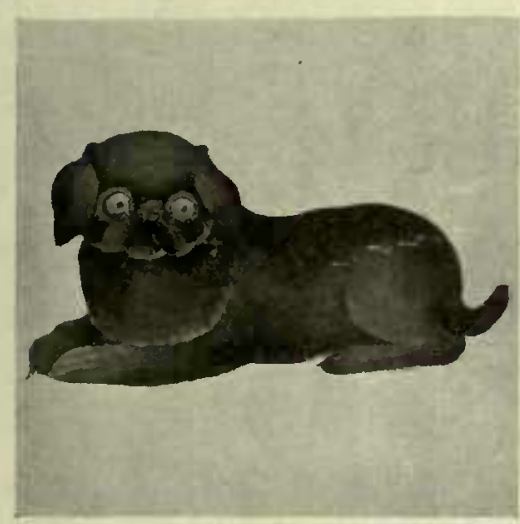

CHINESE PUG DOG,

FROM AN IMPERIAL DOG BOOK



SHEN CHUAN. BY HIGH NFFICIAL OF K'ANG HSI (EARLY) PERIOD

Posthumous name Wen Chuch Kung. His son was also a famous painter, and was born 1669 , died 1735

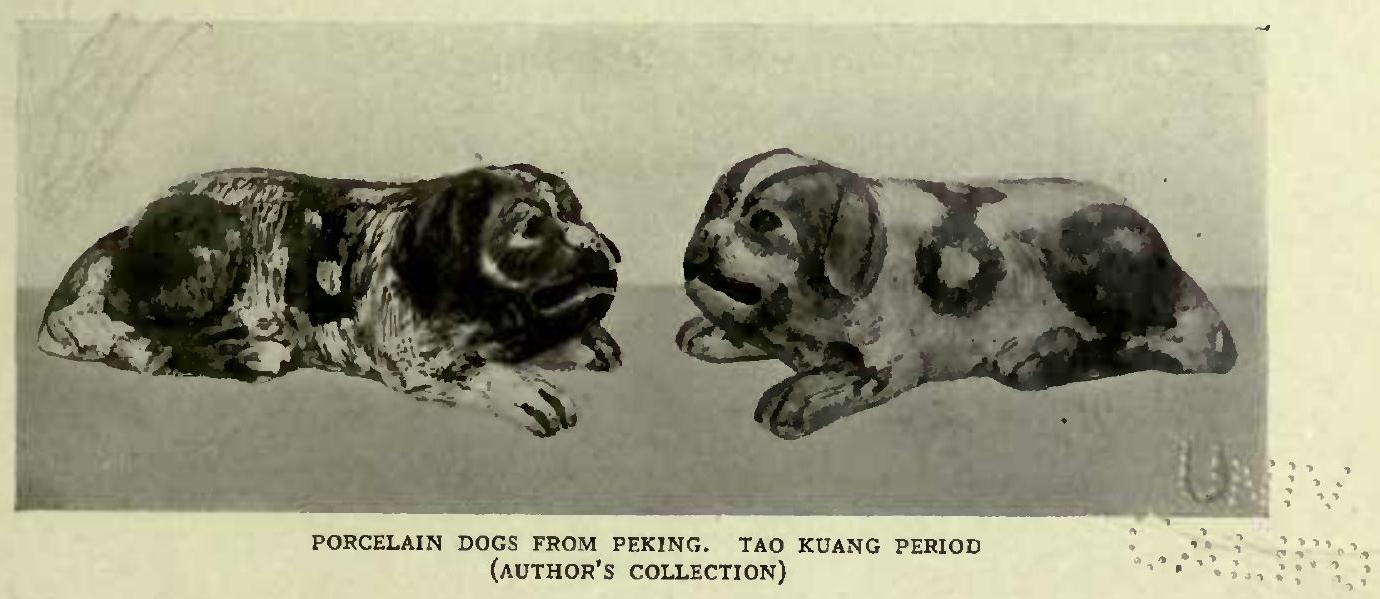

To face $p \mathbf{I}_{4} 6$ 



\section{HISTORICAL REFERENCES TO PEKINGESE TYPE}

names and qualities of each particular dog. There was also tied about the neck of each dog a yellow silk cord drawn through a hole in a little bit of wood which hung from the dog's neck as a mark of its belonging to the court. The Chinese in general are very fond of little harlequin dogs that play monkey tricks. A servant of ours had one of that kind which he sold for an hundred ounces of silver." *

K'ang Hsi allowed the Jesuit missionaries-to build their cathedral near the palace in Peking, and this appears to be the most likely period for introduction of the Peking races of dogs to Europe from China or Japan, for specimens must have been procurable in the Chinese capital and provincial cities.

In speaking of the local products in Peking, a book of the Ch'ien Lung period (1736-1796) says that the city is noted for its Persian cats, which are of great size, and for its Fu Ling dogs, which are extremely small. $f$ Peking and the province of Chili did not cease to be famous for their cats with this period, for the Abbé Grosier states in 1819, "The cat, in China as in Europe, is the tender object of predilection and the favourite of the gentler sex. Those of the Province of Pechili have obtained preference over all their rivals by their pretty ways and by their fine coats. The Chinese ladies never allow them to leave their apartments, where the most delicate of nourishment and the tenderest of care are lavished upon them. These cats are of a pure white, their coat is very long, the hairs fine and silky. Their ears are pendent. They do not catch mice, and leave this ignoble chase to the cats of vulgar race with which, be it noted, China is abundantly supplied." $\ddagger$

" Pinkerton's " Voyages," vol. vii, p.381 ; Bell's " Travels in Asia"; Ismayloff's

"Embassy to Kamhi," I 719.

$\dagger$ "Jih Hsia Chin Wen K'ao."

I Grosier "De la Chine," vol. iv, p. 2 and 5. 


\section{DOGS OF CHINA AND JAPAN}

It seems probable that it was from the Ch'ien Lung period that the Chinese began to call these dogs "Peiching Kou" or "Pekingese "-a name which is now in common use throughout China.

No "Pekingese" appear to have been mentioned or recorded by Lord Macartney's Embassy to Peking in I792, and the first authentic importation into England took place in 1860 . None were shown until some years later.

The official records of the later periods of the Ching or Manchu Dynasty have not yet been compiled and published, but it is probable that they will have nothing to say of the pigeons of the Emperor T'ao Kuang and of the dogs of his consort, matters well-known to modern hearsay, but not considered by modern Chinese historians to be of fitting importance for historical record. 


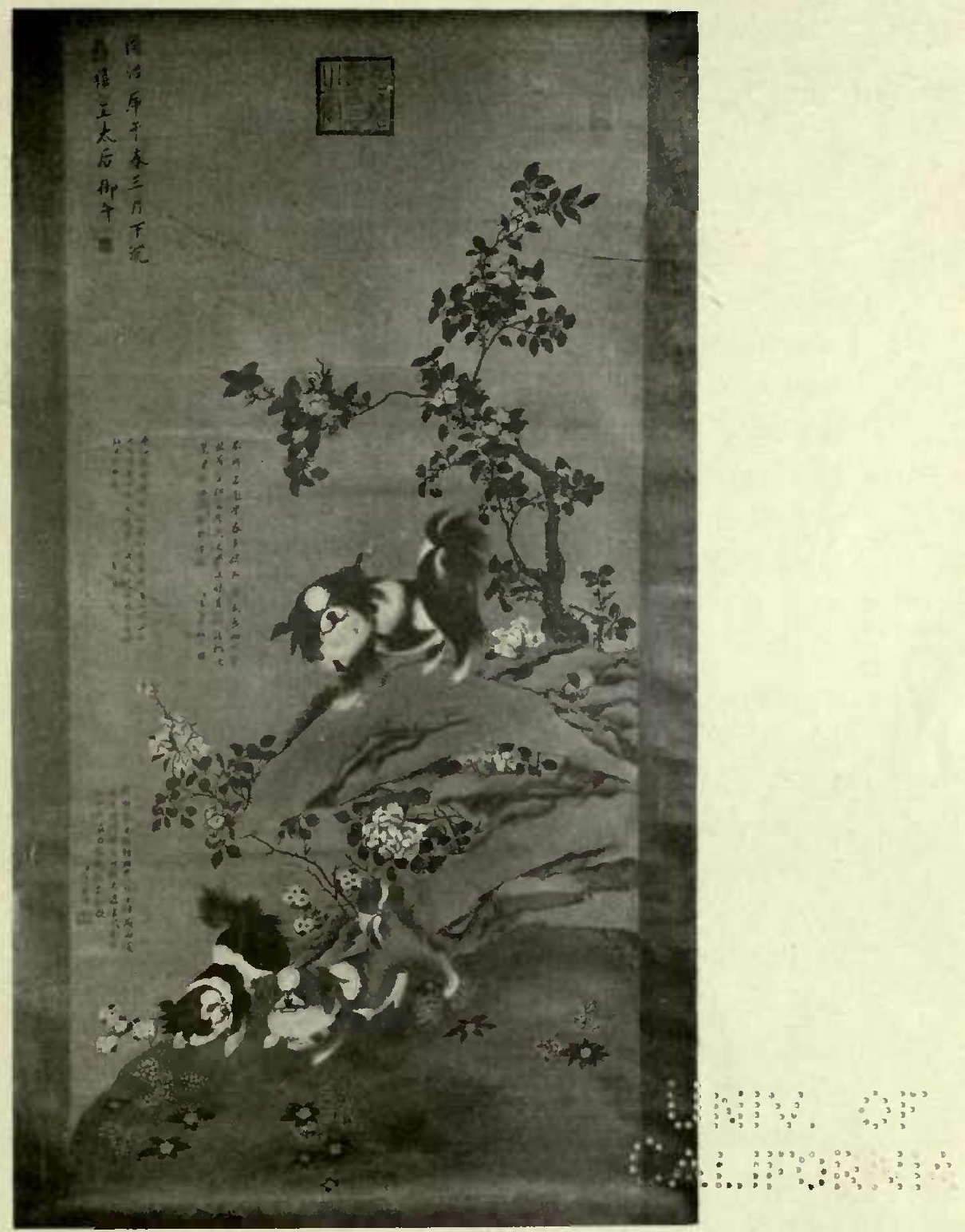

"PAINTED BY THE IMPERIAL BRUSH OF TZU HSI, EMPRESS DOWAGER, IN THE NINTH YEAR OF T'UNG CHIH (I870) IN THE LAST TEN DAYS OF THE THIRD MONTH OF SPRING"

$$
\text { (AUTHOR'S COLLECTION) }
$$

This picture bears the Imperial Seal and congratulatory veraes by three high

$$
\text { Picture presented to Prince Wei by the late Empress Dowager }
$$


$\because \cdots$ 


\section{CHAPTER VIII}

\section{EVOLUTION OF · THE PEKINGESE TYPE}

TANCIERS of the Pekingese breed of dogs, a breed which, to the eye of the present-day European, bears a closer resemblance than do the Chinese and the European lion-dog to the King of Beasts, will ask themselves such questions as: "How far back can the Pekingese type be traced? What is the origin of the breed and of its distinctive points? When was it first remarked as a distinct type by the Chinese? What is the date of its first importation into Europe?"

Knowledge of the existence of "short" and "square" dogs a thousand or more years B.C. is scarcely evidence definite enough to justify a positive statement that small dogs existed in China at quite so remote a period. Use of the name " pai " for a " short-legged " and " short-headed " type of dog "which belongs under the table," at the end of the first century A.D. is, however, evidence which speaks for itself. That this type of dog was outdone by the dogs imported from "Fulin " or "Folin," in both superior intelligence and minuteness of size, appears perfectly clear from the enthusiasm with which the arrival of these dogs, which were not unlikely of the then current Maltese breed, was welcomed.

As regards the points of these dogs, Chinese writers of the T'ang Dynasty would probably have likened them to lions had there been a striking resemblance or if any of them had been particularly shaggy-coated, but they did not. No clear 


\section{DOGS OF CHINA AND JAPAN}

similarity to lions is recorded before the time of Kublai Khan. The first Chinese mention of a "lion-dog " in I37I (Southern Sung Dynasty) probably dealt with the longcoated variety almost invariably referred to by the Chinese when they use the term " shih-tzu," and was a dog of fair size, for it followed and attacked a murderer.

As the Chinese Imperial breed has ancestors which came from Byzantium and were very possibly connected with the Maltese of the period, it is of interest to add a few notes summarizing what is known of that breed in Europe.

On the final division of the Roman dominions in A.D. 395, Malta was assigned to the Empire of Constantinople. The Hon. Mrs. Lytton, in her book on "Toy Dogs and their Ancestors," points out that there were two "Melitas" (Malta and Zapuntello*) famous for their dogs among the ancients, and that they had two breeds, both small, one somewhat resembling the modern "Maltese" and the other "Pomeranian" in type. Without entering too deeply into the relationships of the old type of Maltese dogs, it is of interest to quote one or two references from The Hon. Mrs. Lytton's careful collection. The dogs of Melita were very famous as pets, and were bred by the men and women of both Rome and Greece. There are numerous references to the breed, both in poetry and prose. Difficulties of transport and absence of shows, no doubt, caused the breeds to have considerably less type than modern breeds of dogs, but early references are almost unanimous in describing the specimens as being very small. Aristotle describes the marten as being about the size of a Maltese dog of the little, tiny sort. Athenodorus remarks that the Sybarites cared for nothing but Maltese puppy dogs and effeminate men. Acterius, Bishop of Amacia (about

\footnotetext{
* This town in Italy has been connected through history with the breed, possibly from a reference given by the unreliable naturalist Pliny.
} 


\section{EVOLUTION OF THE PEKINGESE TYPE}

A.D. $375-405$ ) remarks " that the Turks who live in the towns do not keep domestic dogs, and the dogs have no special masters, except the very little tiny Maltese and Polonian ones, which are much prized and which the women of good family rear for pleasure." * Dr. Caius $\uparrow$ wrote : "There are also among us, among the kind of (or, another kind of) highbred dogs, but outside the common run of these dogs (namely) those which Callimachus calls Melitei, from the Island of Melita in the Sicilian Strait, whence that kind chiefly had its origin also. That kind is very small indeed, and chiefly sought after for the amusement and pleasure of women. The smaller the kind the more pleasing it is, so that they may carry them in their bosoms in their beds; and in their arms in their carriages. That kind of dog is altogether useless for any purposes except that they ease pain of the stomach, being often applied to it, or frequently borne in the bosom of the diseased person (easing pain) by their moderate warmth." Fleming, writing in $\mathbf{1 5 7 6}$, added an explanatory note to his translation of Dr. Caius, and remarked of the Maltese that they were" dogges curled and rough all over, which by reason of the length of their haire make showe neither of face nor of body; yet these curs, forsooth, because they are so strange, are greatly set by, esteemed, taken up and made of many times in the rooms of the Spaniels Gentle or Comforter."

The Maltese was subsequently called the Shock dog. Johnston, writing in 1755, describes the Maltese as being " either short-haired or long-haired or maned." "In size they resemble the ordinary weasel." "That they may be born with shaggy coats, their keepers line the places where they lie with sheepskins, that they may always have them

" "Toy Dogs and their Ancestors," pp. 266, 269, 272, 25.

† A physician to Queen Elizabeth, wrote in 1570 . Translated in "Toy Dogs." 


\section{DOGS OF CHINA AND JAPAN}

before their eyes." * "At Lyons in Gaul they were sold for ten gold pieces each, and at Bologna for forty pounds."

In 1588 Harrison speaks of the Maltese, "the smaller they be and thereto if they have a hole in the fore part of their heads the better they are accepted." * This appears to be the first European reference to the "stop " now characteristic of all the breeds of Chinese toy-dog.

Overland communication between China and the Byzantine Empire existed up to the time of Hung Wu in A.D. I37I. Constantinople was taken by the Turks in 1453 ; exchange of dogs may therefore have taken place up to this period, but has not been recorded since the T'ang Dynasty.

The literati continued to call the small race of Imperial dogs "Fu-lin" or "Folin" dog up to the middle of the seventeenth century. This may have been a piece of the literary conservatism common among Chinese writers. The name would, no doubt, have persisted still longer had the breed continued unchanged.

From the latter part of the twelfth century two other breeds -the long-coated Chinese Lion-dog and the Lo-chiang dog were known to the Chinese. Probably no race was called "Pekingese" in China much earlier than the seventeenth century, though the Imperial court had taken up residence at Peking about the middle of the thirteenth century. The people of Peking have no special distinctive name for the "Pekingese" type of dog. This presumably is evidence in favour of its having always been the predominating type among the pet-dogs of the city. No paintings on porcelain or porcelain models of the Pekingese type, dating from earlier than the beginning of the nineteenth century, are known to exist.

It has been suggested that the Japanese toy-dog, whose importation to Japan dates from the seventh century, indicates * "Toy Dogs and their Ancestors," pp. 31, 32. 
PEKINGESE DOG.

From an Imperial Dog Book. Painter unknown.

$\because$.

WHITE PEKINGESE.

From an Imperial Dog Book. Painter unknown. 


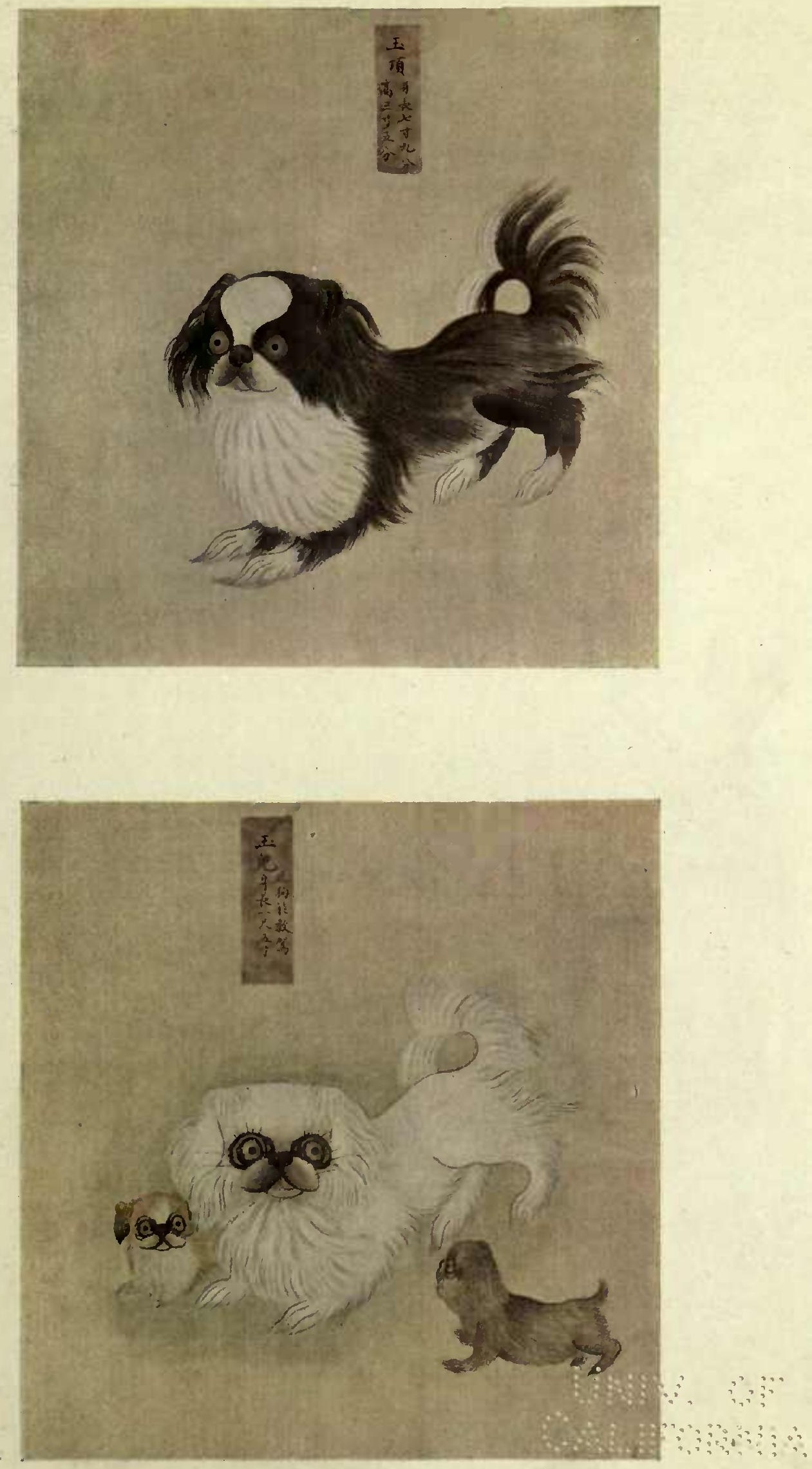



\section{EVOLUTION OF THE PEKINGESE TYPE}

the nature of the "Pekingese" breed of that period. This argument, however, must not be given undue weight, for there has been much communication between the Chinese and Japanese courts at subsequent periods. It is quite possible that the modern Japanese spaniel has varied from the black-and-white Pekingese, common in Peking, only within recent years. In $1867 \mathrm{Dr}$. W. Lockhart wrote that " a small black-and-white, long-legged, pug-nosed, prominent-eyed dog "was one of the two kinds of Pug in China.* It has been remarked that the Japanese is more apt than the Pekingese to breed true.

The Lo-chiang dog was a "pai" dog and consequently small, "short-headed," and "short-legged" before A.D. I00o. It was very possibly the Chinese pug and appears to have been fashionable at the Chinese court from the beginning of the eighth century to the middle of the eleventh centurypossibly even to the removal of the capital from Hsianfu to Peking, about A.D. I 553 .

During the Yuan Dynasty, 1206-1333, there are two references to the "golden-coated dogs," which, on one occasion, are called " nimble " dogs, " commonly bred by people themselves in their own homes." During the Ming Dynasty (r368-r628) lap-dogs appear to have been out of fashion. For the first two hundred years China was practically closed to Europeans. Cats appear to have taken the place of dogs in Palace popularity. That the dogs were still bred appears certain, however. "The lion is tawny like the goldencoated 'nao' dog," remarks a book of the period. $\dagger$

The Manchus captured Peking in 1644. They favoured the Jesuit priests and allowed a limited amount of trade with

" "On the Skull of the Chinese Pug-nosed Spaniel or Lap-dog," by Dr. J. E. Gray, F.R.S., Proc. Zool. Soc., 1867, p. 40.

† "Pen Tsao Kang No." 


\section{DOGS OF CHINA AND JAPAN}

foreigners. Jesuit priests were resident at the Court in Peking, and Kircher, writing in the first days of the Dynasty, remarks that the noble ladies " to pass away their time sport with little dogs, birds, and such delights."

The Manchus, being of Mongolian origin, naturally encouraged the Lamaist form of Buddhism. Thibet had been conquered in 1645 , and in 1653 the Dalai Lama paid a visit to the Emperor in Peking. The popularity of small lionlike dogs at their court appears to have been stimulated by reasons of state in addition to that affection for animal curiosities which has been common to the courts of both East and West from the earliest times. The Manchu Emperors, surrounded by a horde of sycophants and flatterers, and known as the personifications of the Sun and Sons of Heaven, were the last to diminish the importance of any practice which would bring them into association with the Buddhist deities.

The Tibetan grand lamas encouraged this similitude. According to Chinese authorities they originated the Manchu dynastic name, basing it upon the name of Manjusri Buddha, the Chinese Wen Shu, who is always represented in Chinese sacred literature as riding upon a lion. "According to report handed down by the ancients, the Manchu power was strengthened from the time that in sending state dispatches the Tibetans honoured the Manchu Emperors by calling them the Man Chu Hsi Li (Manjusri) Emperors, which name in the Buddhist Gospels denotes Wen Shu Buddha." * A Chinese scholar suggests that the sending of lion-dogs to Chinese Emperors by the Tibetans symbolized presentation of lions to Wen Shu Buddha.

The early Manchu Emperors were extremely fond of sport, and spent much of their time in hunting and shooting. They

- " Complete Chinese Geography " (" Ch'ung Hua Tihi Ch'uan Chih "). 




NINE BUDDHIST LIONS.

"May nine generatiens live together in peace." Lions and embroidered balls

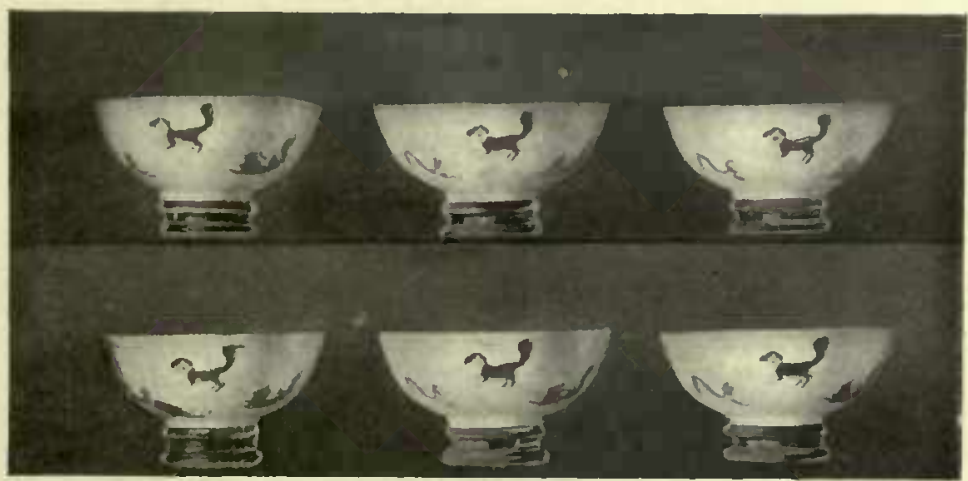

PORCELAIN BOWLS WITH EIGHT DOGS, TAO KUANG PERIOD (PA-ERH KOU)
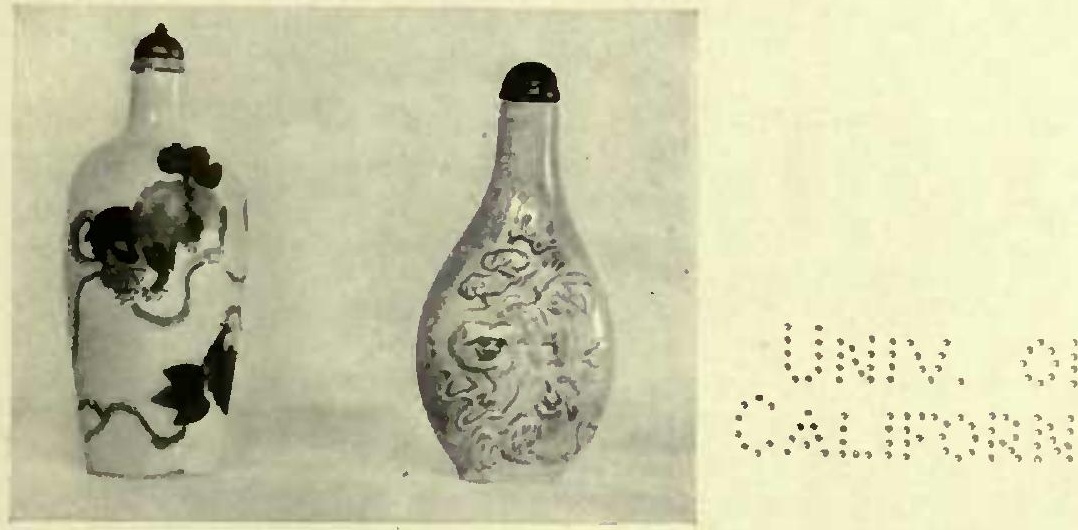

PORCELAIN SNUFF BOTTLES, PEKING 
40

40 


\section{EVOLUTION OF THE PEKINGESE TYPE}

kept numerous dogs for the pursuit of deer, tiger, and bear in their parks, and even used hunting-lions. It is, therefore, not surprising that the court ladies took special interest in pet-dogs-a race which is considered by the Chinese of Peking to be specially associated with the Manchus. In the north Manchurian home of the dynasty breeds of toy-dog still exist.

Association of the Manchu Emperors with Lamaism, with Manjusri, whose " hah-pah" dog was transformed into the mighty lion upon which the Buddha was accustomed to ride, and with the numezous Lamaist monuments of spirit-lions cast or chiselled during the days of Ch'ien Lung and K'ang $\mathrm{Hsi}$, suggests that it was during early Manchu days that the "golden-coated nimble-dog" of Peking became modified by a combination of the characteristics of the breeds existing in Peking and in Manchuria, to something of its present form.

The cult of the lap-dog in China appears to have reached its chief development during the Tao Kuang (182I-I85I) period. The Chinese will explain that the Manchu nobles and ladies never had greater surplus of rents and "face-powder" money to send to the "Old Home " in Manchuria than during the Tao Kuang period, and it was possibly then that the " sleeve-dogs," stunted dwarfs of any breed-known to exist to this day at Aigun* and Hsia-kwei in Northern Manchuria

* The following is from a reliable Chinese correspondent: "A breed recognized as sleeve-dogs exists at Aigun in Hai-Lung-Kiang, and in all the vicinity. I have a friend who is a native of I-Lan, where, he says, sleeve-dogs are very plentiful. They are very small and extremely intelligent. They can take things with their mouths as men do with their hands. They know how to sit, beg, roll and to do other tricks. Owing to their small size and weakness, they are always defeated by cats, when caused to fight with them.

"Most of the rich persons, managers of shops, or those of such inclination keep these dogs. During the period when big sleeves were fashionable, these dogs were kept in the sleeves and were called 'sleeve-dogs.' At the present time, however, they are called " Pen-Lo" (lump forehead) 'Pa-Erh,' or the 'Shih-tsu Pa-Erh' (lion Paerh). The name ' sleeve-dogs' has disappeared. 


\section{DOGS OF CHINA AND JAPAN}

-were imported into Peking. After nearly a century of peace and prosperity, the inhabitants of the capital had become rich, food stood at less than a quarter of its present prices, and the cost of living was extraordinarily low. It was possibly at this period, if not at the time of Lord Macartney's visit to Ch'ien Lung in 1795, that England first heard of Chinese "sleeve-dogs," and of the curious custom connected with their name-a name, by the way, which is now unknown to dog-fanciers in Peking. Dogs do not appear to have been carried in the sleeves in Peking within the last seventy years, for the late Empress Dowager objected to the artificial dwarfing of such small dogs, which are always in the nature of freaks. Broad sleeves have been out of fashion in Peking since 1900 .

It does not, however, appear at all certain that the custom of carrying dogs in their sleeves originated among the Chinese.* Of the shock or comforter (now called Maltese) dogs Daubenton, a commentator on Buffon's " Histoire Naturelle," remarks : "These dogs were very fashionable a few years ago,

"The following are average measurements of this kind of dog :

Length of body . . . . . . 7-8 in.

Height of body . . . . . . 3.5 or $1.8 \mathrm{in}$.

Length of leg . . . . . . . 1.6 or $1.8 \mathrm{in}$.

(Measurements converted from the Chinese.)

Tail, together with fringe . . . . about 3 in.

Coat: Same as the Pekingese ('Pa-Erh Kou').

Long-coated and short-coated.

Head : Upper part rectangular and under part round.

The forehead is high; mouth very short; bridge of the nose pressed inward ; tip of the nose tilted upwards; panther eye ; ear like the leaf of the apricot. The head may be generally described as a 'lion head.'

"From the above it appears that there is practically no difference between these dogs and the Peking 'Pa-Erh' dog.

"This kind of dog produces only one or two in each litter. In the city of Kirin itself there are many long-mouthed large ' $\mathrm{Pa}$-Erh ' dogs. It is unknown whether small specimens of this breed of dog exist there."

" James Watson's "The Dog Book." 


\section{EVOLUTION OF THE PEKINGESE TYPE}

but at present are hardly seen. They were so small that the ladies carried them in their sleeves."

The long coat, including the flowing sleeve, was for many centuries the Chinese hallmark of gentility. During the $\mathrm{K}$ 'ang Hsi period spectacles and thumb-ring gave added importance to the wearer, and a little later it became the fashion to greet a friend by producing a costly snuff-bottle for his admiration and refreshment. This custom became universal under Tao Kuang, a stout supporter of snuff. His conjugal devotion and the passion of his wife for dog-breeding were therefore fittingly pictured upon the snuff-bottle. So carefully was the breeding of the Palace dogs attended to during this period, that eight distinct varieties are said to have been evolved, giving a fresh meaning ("pah'rh "-in colloquial " eight ") to their race-name. Their differences appear in some cases to have been largely a matter of colour and length of coat. The Yellow City must have been the home of many thousands of dogs, and the eunuchs, up to four thousand in number, living in the "Forty-eight Places" of the palace, vied with one another in producing remarkable specimens. It was not the custom of that period to dock the tails of the palace dogs. This custom does not appear to have been introduced previous to the Hsien Feng (185I) period. This Emperor shared the enthusiasm of his predecessor for the Imperial breed. Short "docking" appears to have been introduced, and to persist, under the impression that more compact growth of the body is thereby induced.

The late Empress Dowager Tzu Hsi's fondness for the "Pekingese" breed is well known. She and the Eastern Empress had nearly a hundred dogs under their personal supervision about thirty-five years ago. She seems to have encouraged the comparison of her lion-dogs to the spirit-lions of Buddha, with a view to attracting to herself-universally 


\section{DOGS OF CHINA AND JAPAN}

known in China as the "Old Buddha "-more of the prestige rendered to the Lamaist Buddha by the might of his supernatural leonine supporters.

Miss Carl, who spent ten months at the Chinese Court, says that the Empress, being an artist, was chiefly interested in breeding to colour and in developing symmetrical markings on her dogs. She was most desirous of securing a white foreheadspot and symmetry of saddle-mark upon the back of her specimens. She strongly deprecated the development of any abnormality of form, such as very bowed legs, short nose, or protruding tongue. One of the favourite dogs of the Empress was of the long-coated variety, which she called Tibetan. The Empress Dowager was not successful in breeding this somewhat delicate race.

Miss Carl saw some of the Imperial dog-books. The only dog described as a "sleeve-dog" was a short-coated variety of very small size. The Empress Dowager objected strongly to stunting in Pekingese or any other breed.

Europeans appear to have first remarked the "Pekingese" breed of dogs on the occupation of the Chinese capital in I860. The finding of a small "Pekingese " dog (afterwards christened "Looty") by Capt. Dunne at the destruction of the Yuen Ming Yuan Palace by the Allied troops, and its subsequent presentation to Queen Victoria, are matters of history. At least six specimens appear to have reached England during this period, but the only offspring of the dogs then imported appears to have been that of the pair secured by Lord John Hay.

Dr. Rennie remarks in 1861 that the breed of Peking dogs was a very peculiar one- " something between the King Charles and the Pug." He states that many of the dogs were forcibly taken from their owners during the occupation of the city. He also describes a visit to the Lung Fu Ssu, 152 


\section{EVOLUTION OF THE PEKINGESE TYPE}

where he purchased " one of the little dogs peculiar to Peking," and paid about two-and-a-half dollars (then about ten shillings) for it, another being bought for twenty dollars.*

The difficulty of obtaining dogs from the palace prior to the Boxer troubles in 1900 , together with the long voyage to Western Europe, accounts for the fact that few palace specimens were imported prior to the death of the late Empress Dowager in I9II.

After the Boxer trouble, on returning to Peking from Shansi, the Empress Tzu Hsi presented Mrs. Conger, wife of the American Minister, with a pair of the palace dogs. She also gave one to Miss Carl, who painted her portraits, one of which includes the Empress's favourite dog Shadza (lit. "fool ").

At the funeral of the Empress Dowager in I9II, Moo-Tan (Peony), a yellow-and-white dog with a white spot on its forehead, was led before her coffin by the chief eunuch, Pi Hsiao $\mathrm{Li}$, in obedience to the precedent which had been set nine hundred years before, when the favourite dog of the Emperor T'ai Tsung of the Sung Dynasty was led in state to his master's tomb. In due accord with precedent, too, the late Empress's dog was supposed to have died at the time ; others state that it was sold by one of the eunuchs.

The Lung Fu Ssu Temple, mentioned by Dr. Rennie, is now the scene of a fair held for six days in every month. It shares with the Hu Kuo Ssu, another old Lamaist temple, the distinction of being the only Chinese market for "Pekingese " dogs, and is regularly attended by eunuchs from the palace, who often sell inferior dogs at prices varying from a few to about thirty dollars. The story is current in Peking of the much-prized European pet of the Imperial breed which was stolen and ultimately redeemed from a Chinese owner.

* D. F. Rennie, "Peking and the Pekingese," John Murray, 1865. 


\section{DOGS OF CHINA AND JAPAN}

It was proved on investigation that the cherished treasure had changed hands at the Lung Fu Ssu dog-cheap indeed at about sevenpence (thirty cents).

Dogs of good breed still exist in Peking ; but native interest in them has dwindled with the diminishing power of their Imperial protectors, and with the increasing poverty of the Manchu nobles. It appears likely that unless a powerful reaction sets in within the next few years, the present dearth of good specimens will reduce the race in Peking to a dodo-like extinction. 


\section{CHAPTER IX}

\section{POINTS OF THE CHINESE PEKINGESE TYPE}

$7 \mathrm{HE}$ present-day Chinese attach chief importance to head development in their specimens. This is

1 possibly due to the fact that strong and well-developed body-points are the rule rather than the exception in Peking, where the chief weaknesses are degeneracy of the head, possibly due to exportation of many of the best specimens, and shortness of coat, owing to the heat of the summers. The Chinese distinguish between two distinct types of head -the abacus-ball-shaped ("suan p'an tze-erh") and the apple ("p'ing kuo") or dome-shaped. First-rate specimens of either type are held in equal estimation. The abacus is the Chinese counting-board, and the shape of the abacus ball may be reproduced by cutting off about one-fourth of its width from opposite sides of a wooden sphere. The characteristics of this type are shortness between the face and back of the head, together with broad dome giving, with the setting-on of the ears, a rectangular look to the head.

It is in this type of head that an endeavour is made to reach the ideal of having the eyes so far apart and the tip of nose and forehead so much in the same plane that a silver dollar (about the size of a half-crown) will, if lying flat on the plane of the dog's nostrils, touch the forehead, and at the same time lie at its broadest between, and not covering, any part of the eyes. The Chinese description of this type of face is " knife-cut mouth " (" tao ch'ieh tsui-rh "), the idea being 


\section{DOGS OF CHINA AND JAPAN}

that the appearance of the nose is as if cut with a knife slicing downwards on the front plane of the forehead. In this type, the face should be as rectangular as possible ("Ssu fang li-erh"), and not long and oval-shaped ("ch'ang hua li-erh ").

The apple-headed ("p'ing-kuo nao-tai") type of dog is broad from the face to the back of the head, has a domed forehead, the front of the skull protuberant, and the eyes less far apart. This shape is reminiscent of the King Charles and Blenheim spaniel type rather than that of the English "Pekingese." It seems likely that these points are characteristic of two distinct varieties which have, in modern times, been crossed through paucity of really good specimens of either breed. Among the colours best liked are :

(I) The tortoise-shell face (" ai ming li-erh"), considered attractive on account of simulation of laughter;

(2) The three-flower face ("san hua li-erh "), which is black round the eyes, yellow on forehead, and white round the mouth ; and

(3) The head black ("wu t'ou") with the remainder of the body another colour.

The shape and insetting of the nose, the most distinctive feature of the race, are perhaps of relatively less importance in China, where the objective of the breeder is not necessarily altogether snub-nosed, than in the West. Chinese breeders insist that the best shape for the tip of the nose is that of the "Ru-yi," a Buddhist emblem in the nature of a sceptre, whose shape and significance are equally difficult of definition. The name refers to the boss at the end of the "Ru-yi," which is very similar to another and rather more fixed standard of shape, that of the Chinese conventional cloud. This latter is the nose outline found in most of the bronze Chinese lions. When the nose is somewhat depressed at the tip, 156 
PEKINGESE DOG BY TSOU YI-KWEI-1686-1766.

Vice-Minister of Board of Rites. From an Imperial Dog Book.

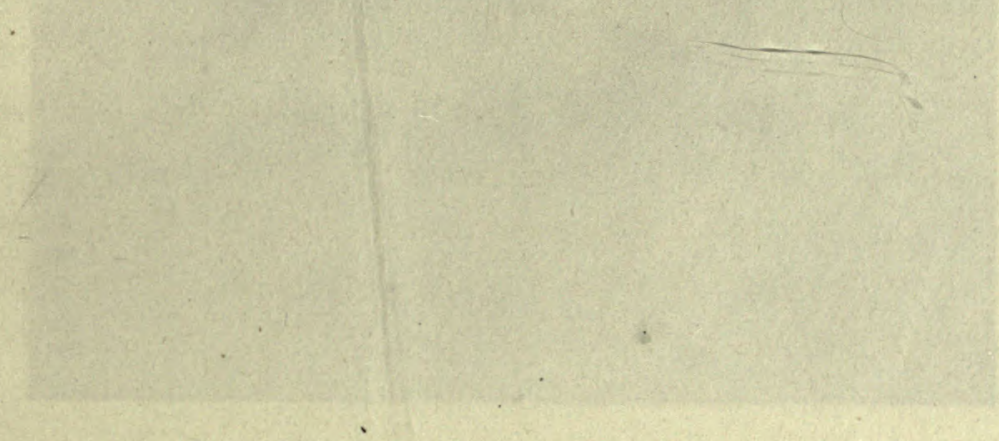

CHINESE PUG.

From an Imperial Dog Book. Tsou Yi-Kwei, K'ang Hsi period. 


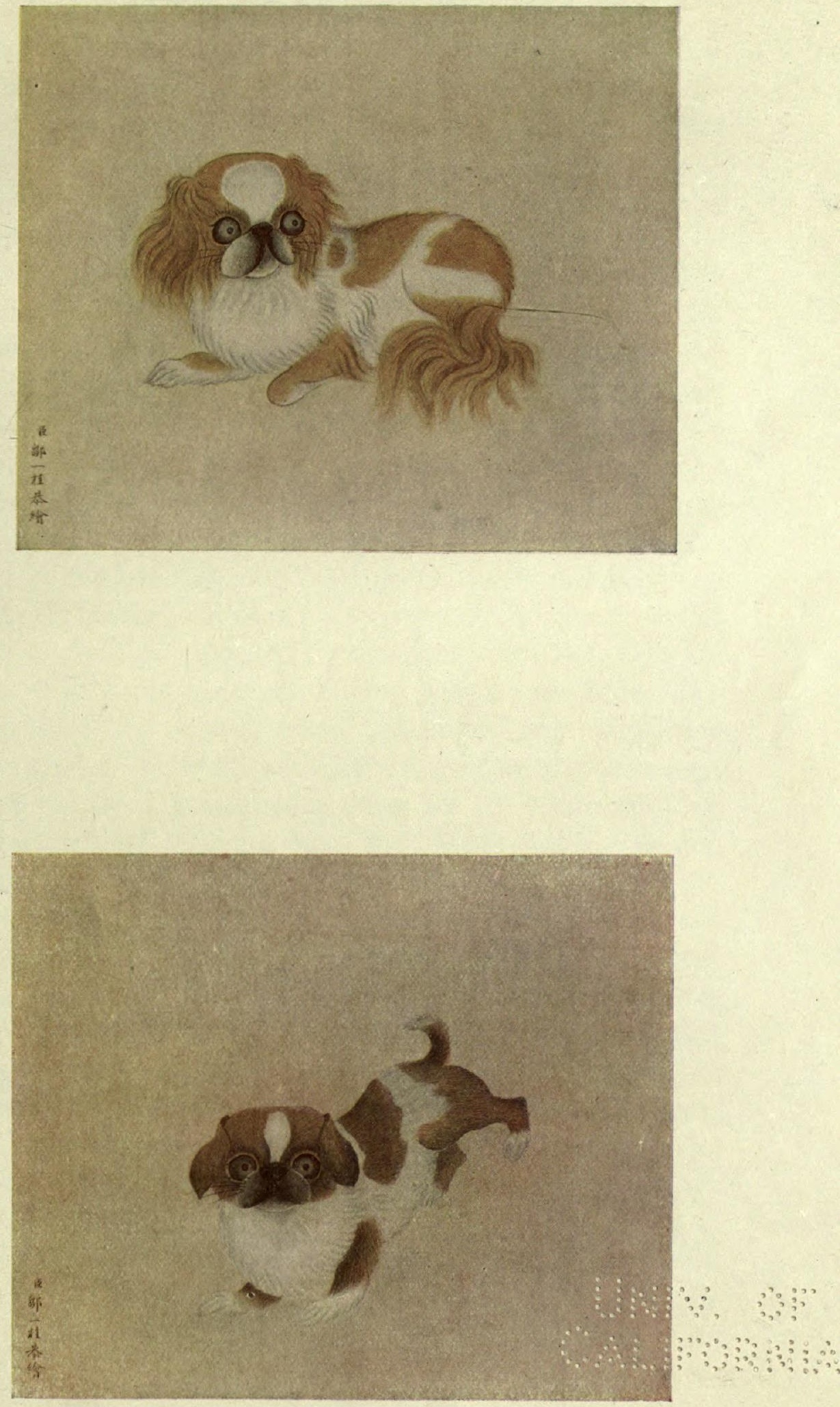



\section{POINTS OF THE CHINESE PEKINGESE TYPE}

giving a rounded or somewhat hooked expression, the name "sheep-nose " is applied. If very pointed at the tip, with the side lobes somewhat depressed, the dog is said to be tortoisenosed. The nose must, of course, be black-tipped. There is doubt as to whether this is the case with the tongue, for though the tongue of the Chinese chow-dog must be "like as if he had been drinking ink," this does not appear to be essential in the "Pekingese." The encouragement which this point does obtain is said to be due to the opinion held by Chinese breeders in Peking that dogs with spotted or black tongues are more easily saleable to Europeans. The tongue of a well-bred dog should, from birth, have a tendency to project a little to the right or left of the mouth. This point is frequently illustrated in the "Dog Books," and though discouraged by the late Empress Dowager, is much valued by the majority of Chinese. It may be mentioned that the Lamaist "hou"-a mythical animal very similar to the lion-is represented with an inordinately long tongue, the possession of a similar characteristic being also one of the thirty-two Superior Marks of Buddha. The tongues of Chinese dogs are often rendered permanently long by forcible stretching during puppyhood. In this case, the tongue projects in the middle of the mouth. This is considered a bad point. A very long tongue is sometimes the result of pneumonia, and the Chinese refer to it as a "strangled ghost" ("Tiao Sze Kwei"), on account of the fact that in Chinese plays the masks used to represent the ghosts of the garotted or hanged are made with protruding tongues of extraordinary length.

An interesting phenomenon is the fairly frequent appearance of very large-sized dogs, nearly always with fine head-development. This is said to be encouraged by over-feeding; but the occurrences appear to be throw-backs to large-sized ancestral stock. If of male sex, these are never used for 


\section{DOGS OF CHINA AND JAPAN}

breeding, but become guard-dogs for the owner's kennel, which often among the breeders of the palace contains as many as twenty dogs. The eunuchs also use them to a certain extent for dog-fighting.

The ears should be placed well behind the middle axis of the forehead, not too high on the skull, and should be well feathered (not turned outwards in front), giving the appearance of a rake ("pah-tzu "), nor yet projecting at the side (" chaiotzu," or horn-ear). Other bad points occasionally found in China are sesamum-seed ear (" chih-ma-erh-t'ou," or prickear), or the ear sharp-pointed and pushed forward.

The mouth and cheeks may be somewhat round and dumpling-like, not under-shot as to the lower-jaw ("Ti kai tien," "earth covers the heaven"). The lower jaw and chin should be well developed, not frog-like ("ha-mah tsui"). There should not be projection of the upper and lower lips and gums (" to cherh "). The best mouths, of course, are those. in which the lower part of the face is in the same plane as the front of the ear ("tao ch'ieh tsui").

The Chinese liken the eyes of their best specimens to the "Loong Ching Yü" ("dragon-eye fish"), or gold-fish. They should be very large, lustrous, and prominent, with the iris broad and of old-gold colour (" bi chi yen-erh," water-chestnut eyes). If showing rather more white they are called "leopard eyes."

Ideal body development-next in importance to that of the head-requires a well-defined waist, slightly concave (syceelike) back, a short, compact and sturdy body, front legs shorter than the hind legs, with the object of producing a rolling gait, which should, however, be steady and free. This gait is compared to the movement of the plentifully finned goldfish. The fore-legs should be short, not straight and sticklike (" chih pang t'ui "); the hind legs should not be bent and 158 



"HO YUN. I820 CHIU CHING." CHIN SHIH, TOONG CHÜ

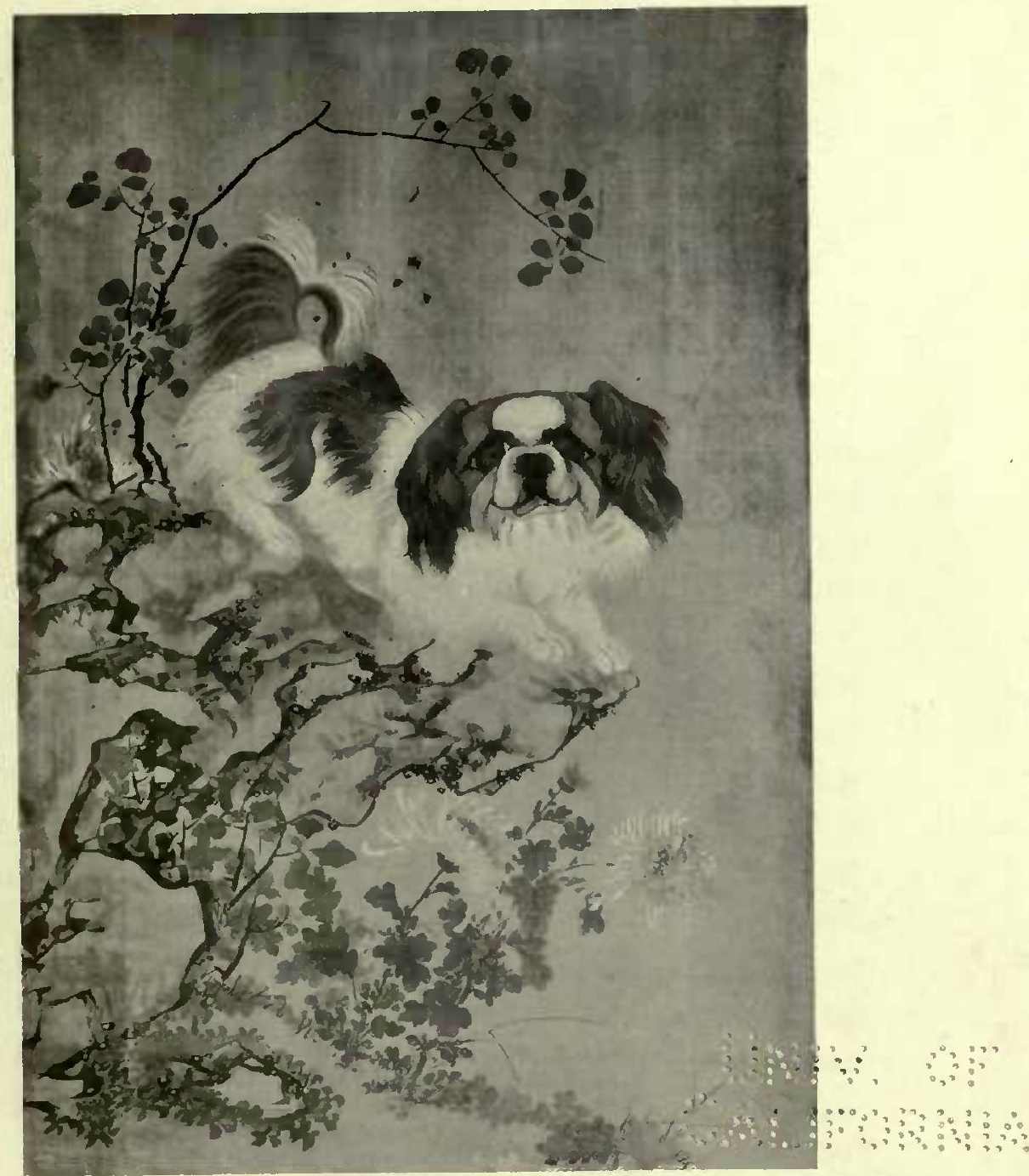

CHINESE PICTURE (RECENT) USED IN BREEDING 
$\because 6 \%$

WOa 


\section{POINTS OF THE CHINESE PEKINGESE TYPE}

hoop-like. The fore-legs should be turned slightly outwards at the shoulder, and there must be a slight curvature thence down to the toes, wlich should turn somewhat outwards, but not enough to produce the serious defect called " crabtoes." The curvature of the fore-legs must not be exaggerated, for in such cases there is usually a deficiency of bone. This fault is sometimes so pronounced as to produce the state of " sitting tiger" (" pah-hu'erh"), in which the dog tends to remain continually seated. Weakness of bone is one of the worst faults. Closeness of the legs is a similar fault, often produced through malnutrition during puppyhood. A certain straightness of leg is admissible in China among the best specimens of "Pekingese" dogs. Exaggerated massiveness and curvature of leg-bone are not considered absolutely essential there. Some of the best "Pekingese" in China resemble the Japanese rather than the English variety in straightness of leg.

Breeders in the Celestial capital associate the special "Pekingese" type with the Manchus. Some of them say that the name "ha-pa" is a Manchu word meaning "to roll in the walk," referring to the distinctive walk and gambols of the "Pekingese" breed.

We might fairly conclude that at certain periods in Chinese history careful breeding was pursued, and that a tolerably fixed type was evolved. Some Chinese breeders state that early in the nineteenth century specialization had taken place to such a degree that eight distinct breeds, instead of the three now remaining, had been evolved. The occurrence, during the Tao Kuang period, of porcelains illustrating eight dogs-possibly a play on the name-is a confirmation of this theory. Much of the distinction between some of these breeds was in length and coloration of the coat and in markings. In Peking, the dogs of this breed carry a coat com- 


\section{DOGS OF CHINA AND JAPAN}

pletely changed twice yearly. This change begins in March with the shedding of the long winter coat. The short summer coat is changed towards August. The shedding of the winter coat is more sudden and complete than in Europe on account of the more abrupt change from extreme cold to the hot summer. Consequently, the Chinese dog is apt to shed its coat in patches, like the camel, and the coat never attains the luxuriance found in Europe. Some fanciers used to send their dogs to the hills during the hot weather in order to avoid this abrupt shedding of some of the coat, for heavy feathering of the tail, a good ruff, " shirt-front," and fringe behind the legs and on the feet are fully appreciated. Some fanciers give their dogs linseed oil in small doses with a view to securing brilliancy of coat.

Of self colours, the Chinese consider three to be important : the apricot, the liver, and the black. The Chinese apricot fruit varies from a golden-yellow on the sunless side to a rich orange red shading into yellow on the sunny side. It is possible that this colour came into fashion on account of the famous specimen owned by the Tao Kuang Empress. Among self-colours this is undoubtedly the most highly prized : and if it is accompanied by a golden silky gloss, the Chinese will make far greater allowance than the European for weakness in other points. So great has been the appreciation of this combination, that it has been embodied in a numerical couplet, "Chin Ssu Ha-pah," * which is proverbial and commonly used in Peking in the drinking game of Noria, which consists in guessing the number of fingers extended by the two opponents. This couplet stands for the number eight, and the golden-coated "hah-pah" dog is caused to compare in rarity with the rank " $t$ 'ou ping t'ing t'ai," the chief button of

- This name dates from the Yuen or Sung Dynasty. Dogs of this colour are believed to have been extinct in China for the last sixty years.

I60 


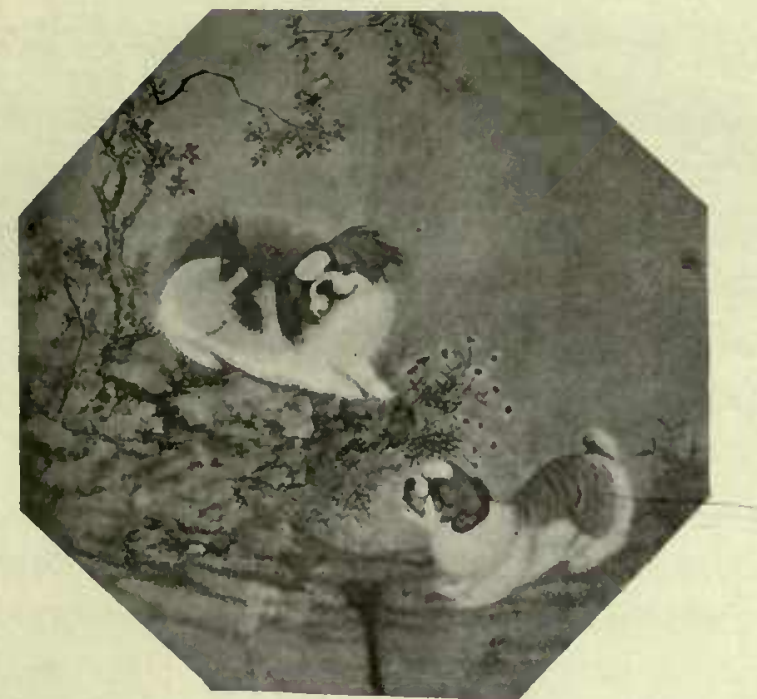

CLOTH LANTERN COVER. SHEN CHEN-LIN

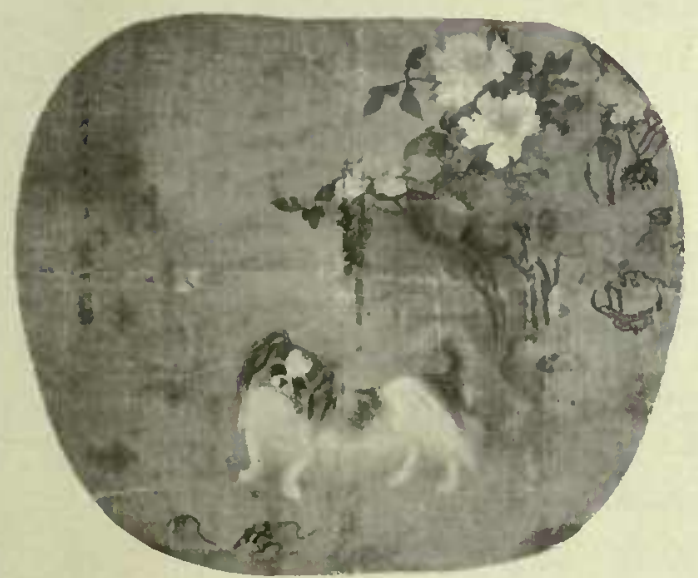

SILK FAN SIGNED " SHEN LIN," IgOI. AFTER THE STYLE OF THE YUAN DYNASTY (1260 A.D.)

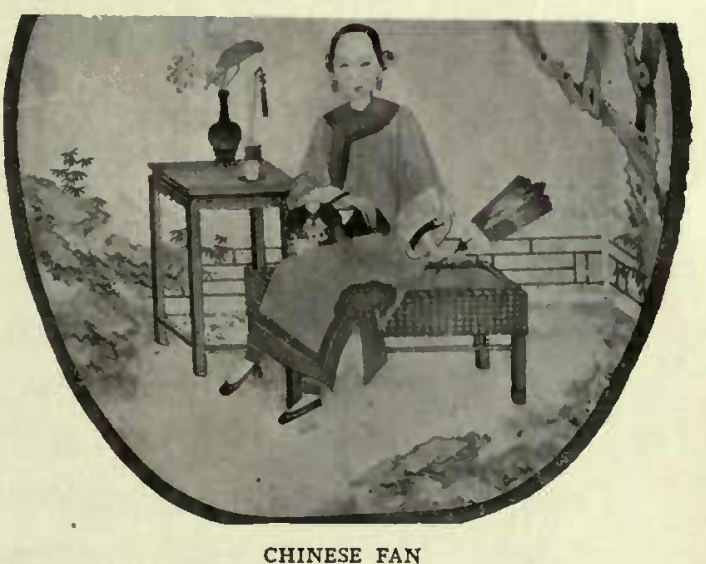

CHINESE FAN
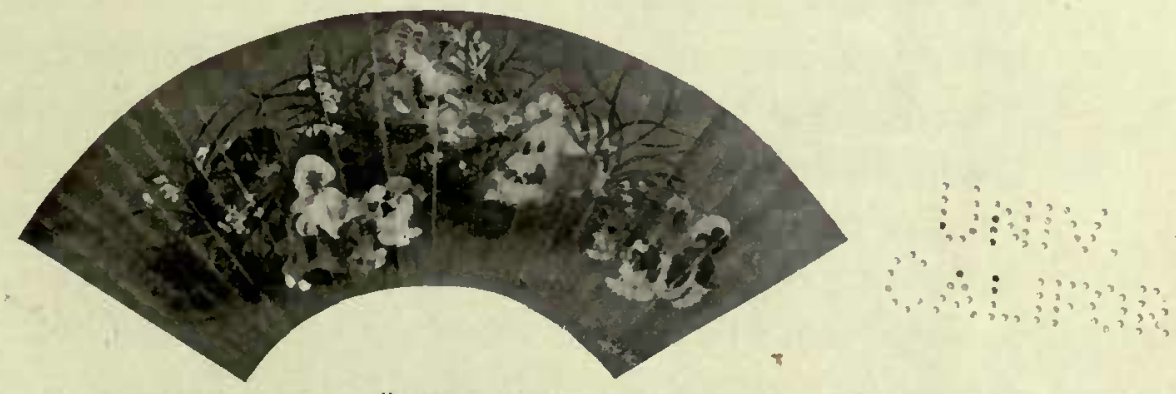

CHIU SHIH TOONG CHÜ FAN. TAO KUANG PERIOD 



\section{POINTS OF THE CHINESE PEKINGESE TYPE}

mandarin rank, a couplet which stands for the number one in the same game.

At one period the Chinese made successful efforts to produce white "Pekingese" dogs, free from the white noses and pink eyes due to albinism. These may date back to the Mongol Dynasty, for the Yuen Emperors appear not to have shared the Chinese objection to white in animals through its association with mourning. Marco Polo records that 100,000 white horses were presented to Kublai Khan on New Year's Day, and this custom continued at least to the time of $\mathrm{K}$ 'ang Hsi.

Among the parti-colours, pride of place is given to tortoiseshell specimens : these are followed in importance by yellow and white, liver and white, and black and white. The Chinese have a picturesque way of describing dogs with special markings as "flowered" dogs. The admiration in which an imported dog, such as the pointer, is held on account of its markings, is very striking to the newcomer in China. It is natural in a city of clans that there should be a tendency to specialize in particular colours among certain of the clans and families. This would render certain colours and markings more stable in China than elsewhere. Similar circumstances may account for the persistence of the white spot commonly found on the forehead of "Pekingese " dogs, and may throw light upon the origin of the Blenheim spaniels whose "spot" is known to have been characteristic in the original breed, though the point now rarely occurs. A white blaze upon the forehead of a horse is believed to be unlucky by the Chinese, and they quote history to prove this. This point in small dogs, however, is prized and encouraged by selective breeding. It may be recalled that one of the thirty-two superior marks of Buddha is " between the eyebrows a little ball shining like snow." In this, we have, perhaps, the origin of the universal 


\section{DOGS OF CHINA AND JAPAN}

Chinese custom of wearing a piece of jade or other precious stone in the front of the hat. The wearing of pearls in this way to mark official rank was a special prerogative of the Manchu Emperors, and can be traced to the T'ang Dynasty (A.D. 6r8). The Emperors of that and other periods gave official rank to their most prized specimens, and perpetuation of the "Ting-Tzu" (official button) thus becomes easy of explanation. A variation of the white spot is the case " T'ung T'ien Bai" ("White [spot] leading to heaven ") in which the spot spreads to a broad blaze on the forehead, sometimes continuing well over the back.

It has been suggested that, because Chinese officials and literati were inordinately proud of their huge horn-bound spectacles, the breeding of "spectacles" into the race of "Pekingese" may have been favoured in China. It is possible, however, that the recurrence of "spectacled" ("Sze Yen ") dogs was not subject to as much encouragement as is found among European breeders. The epithet "four eyes," applied to a man, carries more stigma in China than in Europe. In addition to its connotation of all that is crooked, it bears a special omen of bad luck, derived from Fengshui, and an implied comparison to the canine race. Among the common people the term is also applied to the prig who wears spectacles to ape the wisdom of the short-sighted old man or of the too studious professor. The wearing of spectacles is a comparatively modern custom, and has never been an official sign of rank. It is, therefore, possible that, as in the case of the white "shirt-front "-which is a point of minor importance in Chinese specimens, having no imaginative meaning in China-this matter of the "spectacles" is liable to greater encouragement in Europe than it ever had in China. Chinese breeders distinguish between specimens having the spectacle marks poorly developed (" an ") and those 162 


\section{POINTS OF THE CHINESE PEKINGESE TYPE}

whose markings are clear ("ming sze yen"). To take rank as being suitable for portraiture in the Imperial Dog Books, a spectacled dog should have fire-coated cheeks, fore-legs and rump, and, when in possession of these, is considered very handsome. Other markings which are much appreciated are the "five clear flowers " " wu ming hua"), five clear patches on a ground of different colour, and "three divided flowers" ("san chieh hua"), consisting of three unbroken patches of colour, such as a large spot on the back, another on the head, and another on the hind-legs. A variety of this, which is particularly admired, possibly on account of Buddhist association with the Manjusri's harnessed lion, is the case in which the back-spot is centrally placed and takes the shape of a saddle (" an-tzu hua|"). A similar variety is that in which the saddle-mark spreads right round the body in the form of a sash-marking ("t'ai-tzu hua "), sometimes with an extension on one side like the overhanging flap of the Chinese girdle. The sash is still worn in China, just as was previously the case among the belted earls of Europe, as an exclusive privilege to indicate rank. A yellow belt is worn by certain members of the Imperial family only. Similarly, a white sash-mark on a black dog is taken to simulate the jade belt worn by the Grand Councillors of pre-republican days. Small spots sometimes occur on the coat of the lips and forefeet ("cho hua ti-erh"), and constitute a rather bad point.

Markings which are found on black dogs only are, first, the "sable cloud over snow" ("wu yun kai hsueh"), white feet, white stomach, black back and head; and secondly, the "standing in the snow " (" hsueh li chan "), black coat with four white paws. But white feet in black dogs remind the Chinese of the white shoes used only in mourning. A special name is also given to the specimen having one paw of a colour differing 


\section{DOGS OF CHINA AND JAPAN}

from that of the others ("ku ti'erh"). A hind-leg marking which is appreciated, especially if paired, is that in which the lower part of the leg is of a distinctive colour with a narrow ridge of another colour above it, giving an impression of the Chinese trouser (" $t$ 'ao k'u").

Tiger-stripes on the coat after the manner of a tabby cat are much appreciated. These, however, and the "prince" character written in wrinkles upon the forehead, are attributes rather of the short-coated or Pug type than of the "Pekingese." Similarly, an elastic skin enabling the dog to be picked up by the scruff without pain, though existing to a more pronounced extent in the short-coated type, is looked upon with favour.

Within recent years, the Imperial breed of dogs has been made the sport of Chinese fashion. The Chinese occasionally cross the breeds of the three races of dogs-the lion, the pug, and the Pekingese-and it seems likely that the stock has from time to time been much varied by importation of new blood from various parts of the vast Chinese Empire-a fortunate circumstance, for the breed would, no doubt, be wanting in gameness and fail to possess the spirited and fearless carriage which are among the most important factors in its strong individuality, had there been no cross-breeding from a remote past, in the restricted environment of the Peking palace. It is found that throw-backs to a longhaired type, or to a short-haired pug ancestor, occur occasionally even among "Pekingese" in Europe in the absence of contamination for several generations. It appears not improbable that many of the dogs presented to the Emperors by officials and eunuchs in the Palace were obtained by crossbreeding. It must be explained that although at the end of the Manchu régime there must have been many hundreds of dogs in the Palace, only a few were under the eye of their 164 


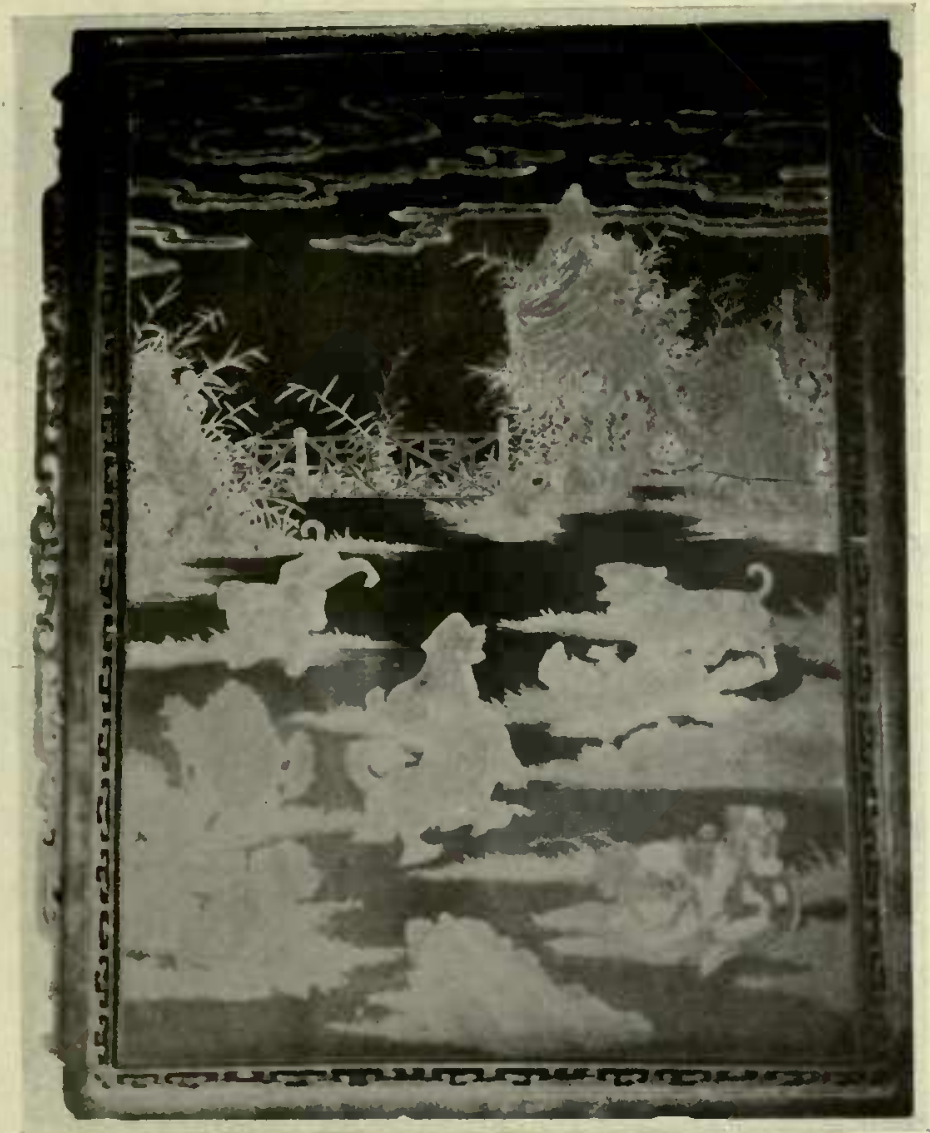

LACQUER PICTURE OF PEKINGESE DOGS, PAY-ERH KOU, K'ANG HSI PERIOD, I662-I723 (AUTHOR'S COLLECTION)



PANEL MARKED “THRE. DIVIDED FLOWERS" DOG. TAO KUANG PERIOD, AFTER LU PAO SHUN, PAINTER OF THE MING PERIOD, HSING KE T'U (HSING AND THE PIGEONS) 
(1)

का 


\section{POINTS OF THE CHINESE PEKINGESE TYPE}

Imperial masters, the rest being bred by eunuchs, who bought and sold among themselves and occasionally presented or sold their best specimens to Chinese officials. As an instance of modification through fashion, it may be mentioned that during the Tao Kuang period the practice of docking the dogs' tails, almost invariably carried out during recent years in the palace, was not always customary. This practice appears to have originated under the late Empress Dowager in the reign of Hsien Feng, after 1815. The change was probably made with the object of obtaining greater resemblance to the Chinese idea of the lion, which is always a "cur tail" beast. The custom of docking is useful as an indicator of the period of Pekingese pictures.

Another change in fashion was due to the Empress's objection to the so-called sleeve-dogs-freaks whose production must often have been the result of much pain. 


\section{CHAPTER X}

\section{THE CHINESE PUG}

$7 \mathrm{HE}$ origin of the European as well as that of the Chinese pug-dog is wrapped in obscurity. Modern 1 European trade with China by sea dates from about I516, when the Portuguese started trading at Canton. The Spanish traded in 1575 from Manila, and the Dutch in 1604 at Amoy and Formosa.

Jesse * suggests that pugs first came to England in the early part of William III's reign (I688-1702), and were then called Dutch pugs. $\dagger$ " At that time they were generally decorated with orange ribbons, and were in great request among the courtiers, from the King (a grandson of Charles I) being very partial to them." During this period pug-dogs may have been imported direct to Holland, and even to England, from China and Japan, for in 1662 the Governor of Formosa, after capture of Fort Zeelandia by the pirate Coxinga, was released from imprisonment through measures taken personally by the Prince of Orange, who subsequently became William III of England. The King's partiality appears to have been due to the fact that the King's grandfather, William I of Orange, owed his life to the warning given, during his campaign against the Spaniards, by one of these dogs.

$\mathrm{Up}$ to the introduction of the inquisition into the Netherlands William of Orange held high rank as governor of

* “Anecdotes of Dogs," Jesse, 1858 .

† The first recorded use of the name in connexion with dogs occurs in 1731 . "Pug. A nickname for a monkey or dog," Bailey, " Skeat's Dictionary." 


\section{THE CHINESE PUG}

Holland, Zealand and Utrecht under the Spanish Government. In 1571 he took up arms against King Philip of Spain, and the incident recorded by Sir Roger Williams must have taken place between this time and the recall of Alva in 1573 . The Portuguese may well have introduced the Chinese pug into Europe, and the dog in question may have been secured from Portugal.

"The Prince of Orange being retired into the camp, Julian Romero, with earnest persuasions, procured licence of the Duke d'Alva to hasard a camisado or night attack, upon the Prince. At midnight Julian sallied out of the trenches with a thousand armed men, mostly pikes, who forced all the guards that they found in their way into the place of arms before the Prince's tent, and killed two of his secretaries. The Prince himself escaped very narrowly, for I have often heard him say that he thought but for a dog he should have been taken or slain. The attack was made with such resolution that the guards took no alarm until their fellows were running to the place of arms with their enemies at their heels, when this dog, hearing a great noise, fell to scratching and crying, and awakened him before any of his men; and though the Prince slept armed, with a lackey always holding one of his horses ready bridled and saddled, yet at the going out of his tent with much ado he recovered his horse before the enemy arrived. Nevertheless one of his equerries was slain, taking horse presently after him, as were divers of his servants. The Prince, to show his gratitude, until his dying day kept one of that dog's race, and so did many of his friends and followers. These animals were not remarkable for their beauty, being little white dogs, with crooked noses, called camuses (flat-nosed)." *

* "Actions in the Low Countries," Sir Roger Williams, printed 1618.

Camuses. The French word camus means " a person having a short and flat nose. Used of the dogs of Artois and Boulogne which were varieties of 'carlin' 


\section{DOGS OF CHINA AND JAPAN}

The main points of difference between the European pug, Blenheim Spaniel, and King Charles Spaniel are the result of modern specialization, rather than of ancient individuality. "It is impossible to distinguish the skull of a Terrier from that of a Spaniel, or either of these from the Pariah Dog of India, or the 'Mongrel Cur' as it is called in England," wrote a learned zoological authority in $1868 . *$ It would be interesting to secure a scientific opinion on the skulls of these breeds as developed at the present time. There appear to have been very few references to European " short-mouthed" dogs, exclusive of the bull-dog, previous to the nineteenth century. The first mention of abnormally short noses occurs in 1845 . Youatt speaks of the new short-nosed type as an innovation. "The King Charles Spaniel of the present day is materially altered for the worse. The muzzle is almost as short, and the forehead as ugly and prominent, as the veriest bull-dog.... The Blenheim Spaniel has degenerated of late. The species may be distinguished by the length and silkiness of the coat, the deep fringe about the ear, the full and moist eye and the blackness of the palate." $\dagger$

Chinese records prove the existence of "short-mouthed" dogs in the time of Confucius, 700 B.C., and similar dogs were used for sporting purposes in Shansi, 500 B.C. But as to shortness of coat there is no evidence indicating the period it was developed in the Chinese pug. The Chinese name for the pug breed is "Lo-sze," and it is interesting to note that (little short-coated dogs with black and écrasé nose). Term probably derived from Italian camoscio or Spanish camusa." "Dictionn. Littré."

"Murray's Dictionary" quotes: "I601. Holland Pliny, 1336, "The former have flat noses, the other are flat and camoise nosed upward.' 1386. Chaucer, Reeve's Tale, 'Round was his face and camuse was his nose.' r751. Chambers's Cycl. s.v., "The Tartars are great admirers of camus beauties.' "

The Hon. Mrs. Neville Lytton says, "A white toy spaniel survived till the time of Queen Charlotte." "Toy Dogs," p. 39.

* Proc. Zool. Soc., 1868, p. 510.

† "Toy Dogs and their Ancestors," Lady Lytton, p. 89. 


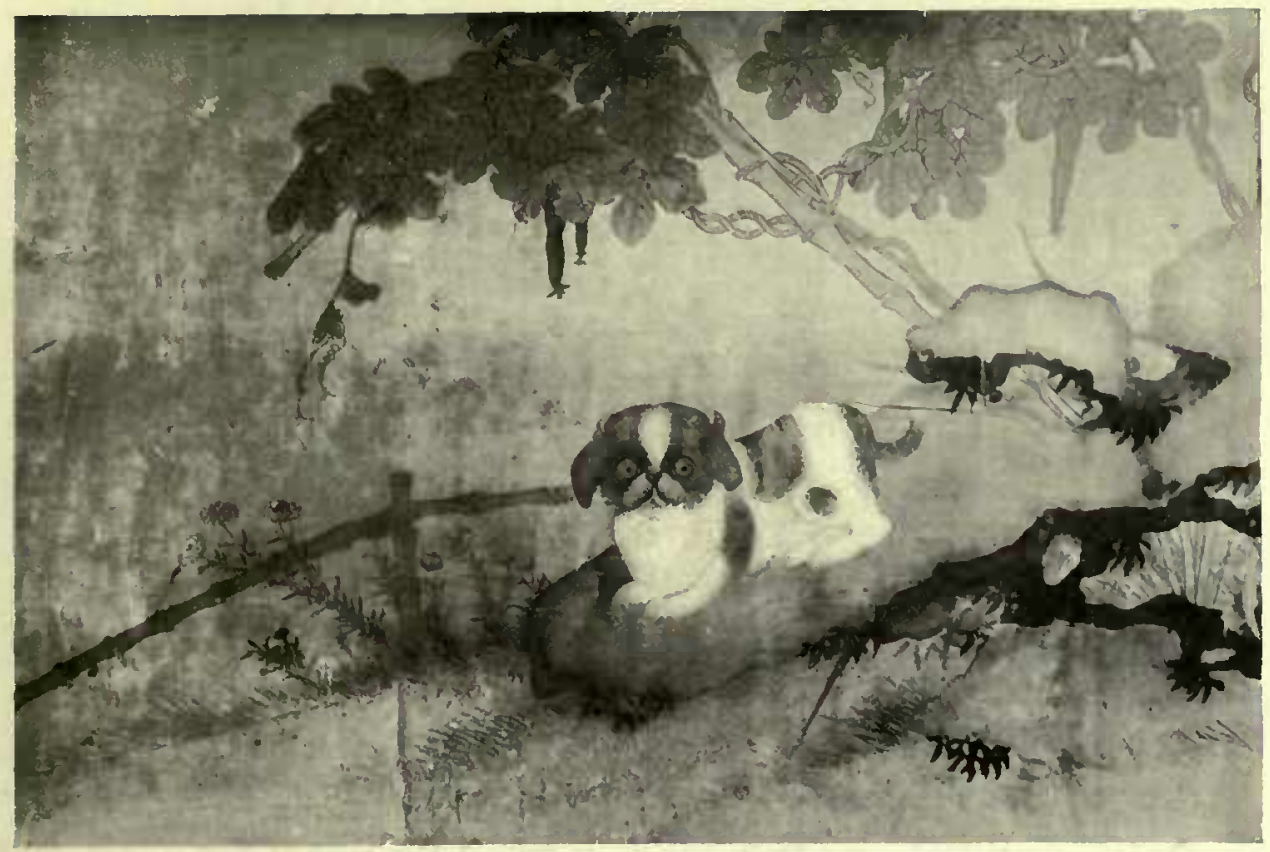

LO-SZE DOG. "SHEN CHEN-LIN. CAREFUL DRAWING"

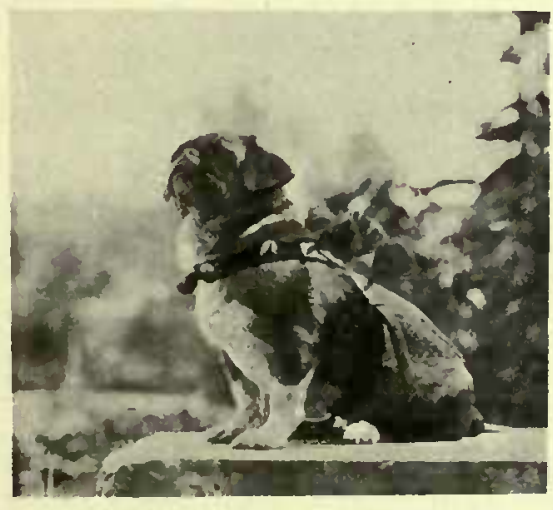

CHINESE LO-SZE OR PUG DOG, PEKING, I9I4

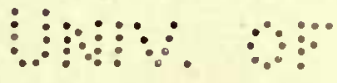
$\because \therefore: \because \because \because: \because: \because: \vdots: \because$ 


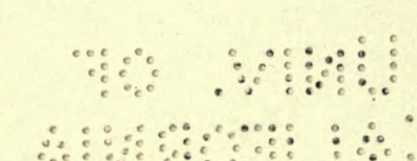

a 400 


\section{THE CHINESE PUG}

the same characters are used to designate the old name of Russia up to the Tao Kuang period. This suggests that the breed came from Russia. It may be suggested that breeders who have been able to secure such extraordinary special characteristics as those of the "Pekingese" found small difficulty, especially in a hot climate, in evolving a shortcoated race from the "short-legged" and "short-headed" pet dog existing roo years B.c. It seems-likely, on the opinion of authorities who have studied the question almost entirely from the European standpoint, that European pugs are the offspring of Chinese ancestors. Vero Shaw (188I) says : "It is my firm opinion that the origin of the present Pug Dog is nothing but the common English fawn-coloured, smooth-coated terrier bitch crossed with a little jet-black Chinese terrier, of which I also have seen some; they have the short nose and high head, and very curly tails." *

Mr. Watson states that, at the outset, the best English pugs were of Dutch origin, and that the Willoughby strain came from St. Petersburg. He says in support of the theory that the pug came originally from China, "We have in the pug a dog which in his peculiarities has no counterpart in any European dog. The bull-dog has a short face, and was square-headed, with cropped ears and a straight tail, when the pug was first known, and had an entirely different temperament from the pug."

"All the English pugs of prominence from 1865 to I895, also all our best pugs from 1880 to 1900 , trace to Click, a dog of pure Chinese stock." $\dagger$

The son of the owner of Click is quoted as stating: " Click's parents-Lamb and Moss-were Chinese beyond dispute. They were captured in the Emperor of China's palace during

"Vero Shaw, "The Book of the Dog."

+ James Watson's " The Dog Book." 


\section{DOGS OF CHINA AND JAPAN}

the siege of Peking in 1867 or 1868 , and were brought to England by the then Marquis of Wellesley, I think. Anyhow, they were given to a Mrs. St. John, who brought them several times to our house. Alike as two peas, they were solid apricot fawn, without a suspicion of white; had lovely heads and expressions; but, unlike their son, they were close to the ground, and a shade long in body."

A later importation which is well known, is that of black pug-dogs brought in 1886 from the East by Lord and Lady Brassey in the Sunbeam.

It is possible that the Chinese name for this breed is connected with the city of Lokiang, or Lochiang, about thirty miles north of Chengtu, the capital of Ssuchuan, which was famous for its dogs from the eighth to the eleventh centuries. Recent inquiries in Ssuchuan indicate that the name of the breed has been forgotten in its birthplace, and that even in this distant province the common name for the small short-nosed dogs is now " Ching-kou " or "Pekingese." One of the most important characteristics of the Chinese Lo-sze dog, is, in addition to universal shortness of coat, elasticity of skin existing in a far greater degree than with the "Pekingese." The point most sought after by Chinese breeders was the "Prince" mark, formed by three wrinkles on the forehead with a vertical bar in imitation of the Chinese character for "Prince." This same character is distinguished by the Chinese in the stripes on the forehead of the tiger, which, in consequence, is the object of superstitious veneration among the ignorant. The button, or white blaze, on the forehead was also encouraged in the Lo-sze dog, but was not of the same importance as the wrinkles. Other pointssuch as compactness of body, flatness of face, squareness of jaw and soundness of bone-are similar to those of "Pekingese," except as regards the ears, which were small 170 


\section{THE CHINESE PUG}

and likened to a dried half apricot, set with the outer face on the side of the head and pointing slightly backwards. The "Chiao-tzu," or horn-ear, is also admissible. The legs are but slightly bent at the elbow. The tail is docked by the Chinese, with a view to symmetrical form. The curly tail, however, is known to have existed ("sze kuo chu-erh "), and the double curl was also known.

The most admired and rarest of the breed was the "loong chua lo-sze" (dragon-claw pug), which was short-coated except for the ears, the toes, behind the legs, and the chrysanthemum-flower tail, all of which were very well feathered. This appears to have been a distinct race which became extinct about fifty years ago. The pug-dog occurred in any colour, and was bred as small as possible 


\section{CHAPTER XI}

\section{THE “JAPANESE" DOGS}

7 HERE appears no doubt that the "Japanese " race of small dogs was introduced from China. Its name in Japanese is "Chin," and the Japanese character
"Chresenting this name is composed of roots denoting representing this name is composed of roots denoting "China " and " dog."

Considerable intercourse had grown up between the Eastern Chinese of Go and the early Japanese, at least as far back as the fifth century. The Japanese started making a serious study of Chinese institutions about A.D. 668.

During the periods of Tien $\mathrm{Wu} \mathrm{Ti}$ (A.D. 673-686) and Ch'ih T'ung Ti (A.D. 690-696) Korea and China constantly presented small pet dogs to Japan.* These dogs appear to have been sent as presents, first to Korea, and thence to Japan.

Eastern records also show that in the fifth month of the year Tien Ping of Shen Wu Ti (A.D. 732), the Prince of Hsin Lo State (Korea was then composed of three states, of which this was the Eastern, adjacent to Japan) sent his envoy, Chin Chang Hsun, with a suite of forty attendants, to Japan for an audience. They took with them as tribute one parrot, one thrush, one Ssuchuan "pai" dog, one hunting dog, an ass, and two mules. $\dagger$

* Jih-pen Chi. Jih-pen Hou Chi. Hsü Jih-pen Hou Chi. Wen Te Shih Lu. San Tai Shih Lu. Liu Huo Shih. "The Dog," Tokyo r9r5.

$\uparrow$ Hsu Jih-pen Chi.

172 


\section{THE “ JAPANESE " DOGS}

It is said that about the year A.D. 794 " pai" dogs became somewhat dear in price in Japan, because all ladies liked to possess specimens of the breed.*

"In the fourth month of the first year T'ien Ch'ang of Chun Ho Ti (Japanese Emperor A.D. 824), the state of Yueh Ch'ien (a Japanese State), sent four dogs as tribute, two of which were 'Tso Tan Ta.Wo' and two of the 'Wo Tzu' breed. $\dagger$ Now the 'Wo Tzu' is a Chinese 'pai' dog."

A brief reference to the history of European intercourse with Japan will be sufficient to indicate that in all probability specimens of the "Japanese" race of dogs reached Europe in the sixteenth century. The Portuguese captured Goa in I5IO, and thence spread their trade throughout the East. Trade relations with Japan were started in 1549. The traders were much favoured, especially by the princes of the island of Kyushu, and, fortunate in the possession of Macao, rich in stocks of European and Indian goods, quickly developed a very considerable trade. Kaempfer, the historian, who was physician to a Dutch embassy sent to the court of the Emperor of Japan in I69I, says "The [Portuguese] Merchants, in exchange for their European and Indian commodities, as raw silk, fine stuffs, druggs, wines, artificial curiosities, became possess'd of immense treasures, and the golden marrow of the country." In 1559 St. Francis Xavier, one of the original incorporators of the Society of Jesus, landed in Japan as a missionary. He was well received. A very large number of Japanese were converted, among them were the princes of Bungo, Arima, and Omura. In I 582 these princes sent some of their nearest relations with letters and presents to pay homage to Pope Gregory XIII. Persecution began in 1586 , but the Japanese, being anxious for commerce, spared the merchants. Kaempfer says :

* "The Dog," Tokyo, April 1915.

$\uparrow$ Jih-pen Ji Shih. 


\section{DOGS OF CHINA AND JAPAN}

"The merchants married the daughters of the richest inhabitants. The gold of the country was exchanged against European and Indian curiosities, medicines, stuffs, and other things of like nature. Upwards of 300 tuns of the precious metal were exported every year."

The Dutch established a factory at Firando just previous to 1600 . In 1637, in consequence of a Portuguese plot against the Emperor, the country was closed by Imperial decree to all Portuguese intercourse. All Japanese returning from abroad were put to death. No boat whatever, of any nature, was to leave Japan, and all Portuguese were banished to Macao. Meanwhile, the Dutch had been making every effort to forward their trade. "No trouble," says Kaempfer, "no expenses were spared to please the Emperor upon whom alone all the good or bad success of their trade depended. The most exquisite curiosities of nature and art were purchas'd and brought over for the annual presents. The oddest and scarcest animals in particular were brought up in the remotest kingdoms of Europe, Persia, and the Indies, to have wherewithal to satisfy their demands, ridiculous and fanciful as they generally were, for animals so strange in their nature, colours and shape, as perhaps never existed in nature." * In 1641 the Dutch were ordered to remove from Firando to Nagasaki, where their factory existed in Kaempfer's time.

The period of British trade with Japan at the beginning of the seventeenth century was brief. The East India Company, successful in its competition with the Portuguese and Dutch in India, was making plans to gain a footing in the trade of the Far East. Its efforts to oust the Dutch from the Japanese trade were not successful. Will Adams, who, arriving about 1600, was the first Englishman to reach Japan, rose to great * " Kaempfer's History of Japan," by J. G. Scheuzer, J. MacLehose. 


\section{THE “ JAPANESE" DOGS}

honour with the Daimio of Hirado. Captain Saris visited the court of the Daimio of Hirado in 1614 . He does not remark upon the existence of a race of small dogs, though he does recommend the sending of " a mastife, a watter spaniell, and a fine grayhound" to the son of the Daimio. In the court minutes of the Company for $16 \mathrm{r}_{5}$ there occurs a passage : "Cloths to be provided for Surat, Persia, and Japan; also sword-blades, knives, and fowling-pieces. Things considered fit to be sent as presents ; two mastiffs, little 'Island doggs,' greyhounds, etc."

Richard Cocks, chief factor for Japan of the East India Company, kept a careful diary of events in the English factory at Firando from 1615 down to the time of the expulsion of the British in 1623 . Some of his letters to his patron, dealing with the wonders of Japan, were submitted to King James I (1603-1625), who, incredulous of these marvels, declared the letters to contain " the loudest lies that he had ever heard." He gives detailed lists of the presents exchanged on many occasions between the Company and the Japanese rulers, as well as between the traders of the two nations. He complains of the enormous number of presents required to smooth the path of commerce. "I know not what else to write, but that my greatest sorrow is I live in a place which hitherto hath byn chargeable and not beneficiall to your worships, by reasons of the precentes contynewally given, it being the fation of the contrey, or else there is no staying for us yf we doe not as other strangers doe." $\mathrm{He}$ makes no mention, however, of the inclusion in such presents of any Japanese dogs except " a great black dogg " given him in exchange for goldfish, which were as yet a rarity in Japan. He does, however, mention, with evident apprehension, the accidental death of a dog which appears to have been presented by the East India Company to Foyne Samme, late 


\section{DOGS OF CHINA AND JAPAN}

king of Firando, and which was kept, apparently at the king's request, in the English factory.

April 4, 16r7.- " Thomas the cook, lefte to attend on Mr. Totton, being a harebreand felloe, threw a kitchen knyfe at Balle, the kynges dogg, which we kept in the English howse, and stuck hym to the hart that he fell downe dead presently. He hath beaten many of our Japon servantes, and had lyke to have kild one of our neighbors servantes the other day. He ys not the man I took hym for, and wrot the Worll. Company in his behalfe more than he deserveth. Yf this had hapned in the tyme of Foyne Samme, who esteemed this dogg much, yt might have cost us all our lives. I sent our jurebasso to exskewse the matter to the kyng, who sent me word he esteemed that the English man did it not of purpose, and therefore willed me not to punish hym, for the deede being donne could not be undon, etc." *

Special efforts were made by the Company to open up trade with China. Writing in 1627 from Batavia, the Company's factors remark: "The third part of the East India's trade, Japan and China, is more than all the rest, and seemeth offered only to the English. These mighty monarchies abound with riches, are civilized peaceably to respond with all. Their clothing is silk, passable in summer, but in winter they are forced to bombast or wear ten coats one over the other." Considerations concerning the trade to China were to be " our next step." The factors then recommended the Court of Directors " to provide European toys for presents to these princes to procure rarities that others have not, to impress conceit of greatness in the vulgar; a wild mastiff dog, because not common, has his attendants and is fanned from flies with as much observance as a principal personage." The factors complain that many of the dogs shipped to the

" "Diary of Richard Cocks," vol. i, p. 247, Hakluyt Society. 


\section{THE " JAPANESE" DOGS}

East by the Company "grow faint and die for want of fresh water and too much salt meat aboard, fresh oaten meal or ground barley is the only food for dogs, and a chain and comely collar to grace them ought ever to be remembered. A Turkey cock and hen given by Capt. Moreton were so much admired that a 'sleight' Chinaman to make a friend by presenting them, would willingly buy the like at 100 ryalls of eight." *

Sir Rutherford Alcock's opinion that the "Merry Monarch" was indebted to his marriage with a Portuguese princess (and thence possibly to Japan) for the race of spaniels called after him would appear to have considerable justification, for it appears not unlikely that even if the Japanese races of small dogs were not introduced indirectly through Portugal or Holland by the traders of those two countries before the arrival of their British competitors, some specimens may have been introduced during the brief period in which British traders were in high favour with Japanese rulers at the beginning of the seventeenth century. Fennel in I84I says of the King Charles spaniel, "This beautiful breed received its name from having been the favourite of that ill-fated monarch Charles I, who rarely walked out without being attended by several of these spaniels. They were black and white, with curly hair, small rounded heads, short muzzles, long ears and webbed feet." $\dagger$

The sending of dogs as Imperial presents persisted in Japan up to at least the middle of the nineteenth century. "The Commodore, upon subsequent inquiry, learned that there are three articles which in Japan, as he understood, always form part of an Imperial present. These are rice, dried fish, and dogs. Some also said that charcoal was

" Calendar of State Papers. East Indies" 1615, p. 429 ; 1617, p. 374.

† "Toy Dogs and their Ancestors," p. 37. 


\section{DOGS OF CHINA AND JAPAN}

always included. Why these should have been selected, and what they particularly symbolize, he did not learn. The charcoal was not omitted in the gifts on this occasion, and four small dogs of a rare breed were sent to the President as part of the Emperor's gift. We have observed also in the public prints that two were put on board Admiral Stirling's ship for Her Majesty of England. The fact that dogs are always part of a royal Japanese present suggested to the Commodore the thought that one species of spaniel now in England may be traced to a Japanese origin. In 1613 , when Captain Saris returned from Japan to England, he carried to the King a letter from the Emperor, and presents in return for those which had been sent to him by His Majesty of England. Dogs probably formed part of the gifts, and thus may have been introduced into the kingdom the Japanese breed. At any rate there is a breed in England which is hard to distinguish from the Japanese dog. The species sent as a present by the Emperor is by no means common even in Japan. It is never seen running about the streets or following its master on his walks, and the Commodore understood that they were costly." *

Records of the several Dutch embassies $\uparrow$ to the Japanese Emperors, which took place during the seventeenth century, though enumerating the presents exchanged on each occasion, do not mention the giving of dogs. A record of cargo brought to England on certain of the ships of the East India Company during this period does not mention dogs, but includes merchandise to the value of some thousands of pounds under the general heading of "toys."

The Bishop of Victoria, writing in I861, remarks that like

" "United States Japan Expedition $(1852-3-4)$," Captain J. C. Perry, vol. i, p. 369 , published 1856 .

† "Ambassade vers l'Empereur du Japon," Henry Drummond, 1686. 


\section{THE “JAPANESE" DOGS}

everything rare and fetching a large sum of money, the Japanese lap-dog was said to come from Miaco. Full-grown specimens might sometimes be seen scarcely exceeding seven or eight inches in length. The diminutive size was secured by cross-breeding, and, according to some, by draughts of saki.*

In recent times, arrival of the Japanese breed of dog, so far as is borne out by authentic records, antedates the Pekingese race as to importation into England by at least a decade. The record of shows demonstrates that nine "Japanese" were classed in a show held in the Holborn Horse Repository in $1862 . \dagger$

Kaempfer fails to mention the existence of the breed in Japan, but remarks, "greyhounds and spaniels are wanting." It is interesting to note that although at a later period dogs were stated always to form part of an Imperial present, the Emperor Iyeyasu's present to King James in 1613 is recorded as having consisted of five pairs of folding-screens.

Huish remarks $\ddagger$ that the dogs usually seen in Japanese art are the Chin or lap-dog, which were introduced from Macao in the seventeenth century by the Portuguese. The authority for this statement is not given, and it would appear far more probable that the Japanese dog was introduced into Macao by the Portuguese, or perhaps from China, and thence found their way to Portugal and to the European Courts. Robert Fortune wrote in 1860 : " The lap-dogs of the country are highly prized both by natives and foreigners. They are small-some of them not more than nine or ten inches in length. They are remarkable for snub-noses and sunken eyes, and are certainly more curious than beautiful. They are carefully bred; they command high prices even amongst

* "Ten Weeks in Japan," by the Bishop of Victoria.

† "Modern Dogs," by Lee. I "Japan and its Art," Huish, p. 136. 


\section{DOGS OF CHINA AND JAPAN}

the Japanese, and are dwarfed, it is said, by the use of sakia spirit to which their owners are particularly partial." *

Idstone, writing in 1872 , states that "Originally the King Charles was a liver-and-white dog." He thought the breed originated in Japan, and said that the first imported Japanese were pale yellow and white. He also thinks that the Blenheim comes from Japan through Spain.

Mrs. Hugh Fraser states that there are two kinds of lapdog in Japan : one, the Chin dog above mentioned, which she refers to as a degenerate King Charles, and " a smooth, rather bald beast with spots, both kinds having prominent eyes." +

" "Visits to Japan and China," by Robert Fortune, pp. 96-98.

† "A Diplomatist's Wife in Japan," by Mrs. Hugh Fraser, p. I19. 


\section{CHAPTER XII}

\section{THE CHINESE LION DOG}

T $N$ studying the origin of the Chinese lion-dog or shock$\mathrm{dog}$, an origin which appears to be closely connected 1 with that of the Lhasa terrier, one or two points in the history of Tibet may be borne in mind. There is no recorded history of the country previous to the seventh century A.D., the people having been steeped in barbarism and devoid of any written language. The foundation of civilized monarchy was laid on the conversion, in A.D. 652 , of Srong-tsan-gampo, who introduced Buddhism and the art of writing from India. He had founded Lhasa in A.D. 639. One of his wives was an Imperial daughter of China.

In 663 the Chinese took Lhasa and burnt the royal palace. Another of the Tibetan kings, Khri-srong-Ide-tsan, born A.D. 730, is famous on account of his strenuous support of Buddhism. His mother was daughter of one of the Chinese Emperors.

In I253 Kublai Khan conquered all the east of Tibet. In 1645 the Chinese again invaded Tibet and conquered the whole of the country, making the fifth of the Dalai Lamas, a title which first came into existence in 1576 , supreme monarch of all Tibet. In 1653 he was confirmed in his authority by the Chinese, and paid a visit to the Emperor in Peking. The Chinese army again conquered the country in 1720 , and established the present system of government.

The Chinese lion-dog ("Shih-tzu kou") is so called chiefly 


\section{DOGS OF CHINA AND JAPAN}

on account of the length and shagginess of its coat. The Chinese readily apply the name to any long-coated dog, whether native or foreign, large or small. Ramsay says that in Tibet these dogs are called "lags k'yi" (hand dogs), " because it is believed that, if a human being lays hands upon a young eagle when freshly hatched, the bird is transformed into a dog of the Chinese pug breed." *

That the Tibetans should have selected their small lion dogs, and in accordance with the universal custom should have sent them as curiosities and presents to the Manchu scholar Emperors Ch'ien Lung, K'ang Hsi, and other sovereigns, as a flattering reminder of the Lamaist association of the Dynastic name with Manjusri, the god of learning, habitually accompanied by a small pet dog capable of being transformed into a mighty lion as his steed, seems perfectly natural. There is evidence that the compliment was acted on in the spirit in which it was given, for the palace eunuchs state that the Emperors were continually followed by their small dogs, and that their entrance to audiences was often announced by the barking of the accompanying dogs-a signal for all servants to hide themselves, or at least to avert their faces.

It is not known when the Tibetan Lamas began to send to the Manchus small Tibetan "shock" or lion-dogs, the earliest English representation of which appears in $\mathrm{Mr}$. Bryan Hodgson's "Drawings of Nepalese Animals." The custom possibly existed in the early period of the Manchu Dynasty, founded in 1583 . It ceased in 1908 , when the Dalai Lama visited the Empress Dowager and presented her with several specimens, which were seen by foreigners who describe them as having been very similar to the breed of lion-dogs then existing in Peking, and known by living testimony to have existed there for at least forty years

$$
\text { * "Western Tibet," Lahore, 1890, pp. 33, } 35 .
$$




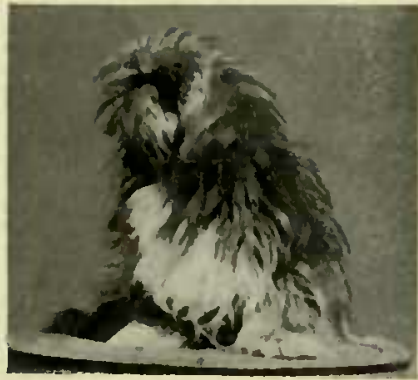

CHINESE LION DOG, PEKING

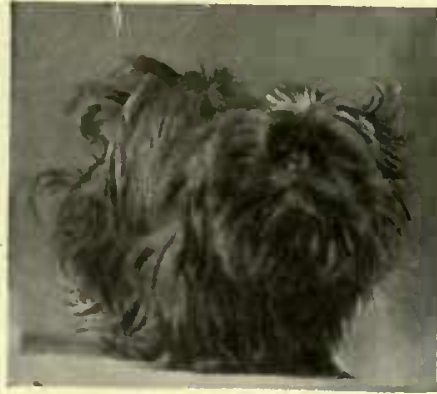

CHINESE, LION DOG

THE PROPERTY OF MISS BIRCHAL PEKING

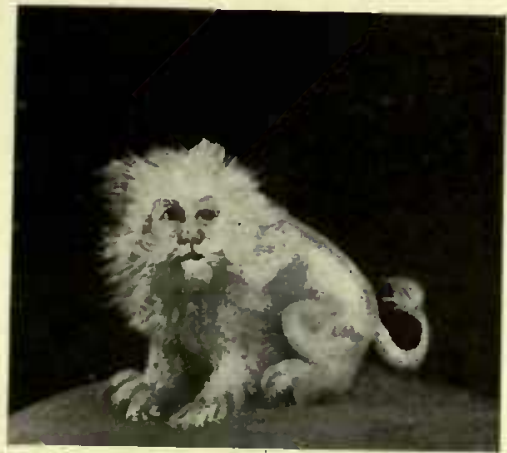

LION DOG FROM THE PORTRAIT OF DOROTHY BRERETON, SECOND WIFE OF SIR PETER LEIGH OF LYME, I6I5 FROM "THE HOUSE OF LYME,". BY LADY NEWTON

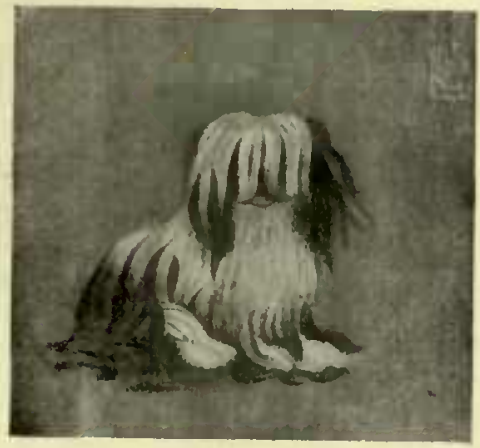

LION DOG FROM AN IMPERIAL - DOG BOOK

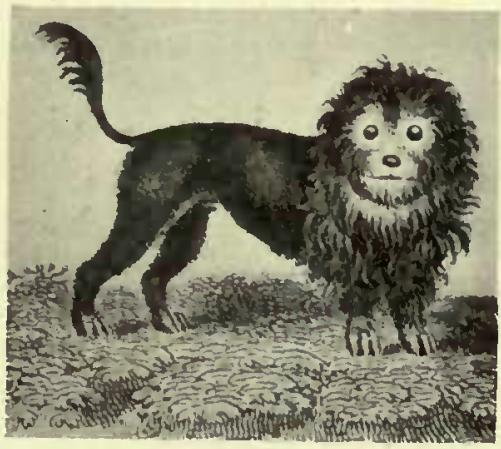

THE LION DOG REES'S CYCLOPEDIA, I 820

To face $p \cdot x_{2} s_{2}$

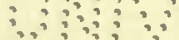

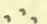

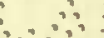





\section{THE CHINESE LION DOG}

previously. A similar breed exists in Shantung, but there are two varieties of the Shantung lion-dog, one of lap-dog size, evidently referred to by Dr. Lockhart in 1867 when he wrote, "From Shantung is brought a beautiful black, longhaired, long-backed, long-legged terrier, very much like a black Skye," * and the other shock-greyhound similar in all respects to the European greyhound, except for its shaggy coat. Laufer $\dagger$ quotes from the "Annals of Shantung Province," "There are various kinds of dogs. There are the barking dogs with short muzzle and thin legs, excellent hunters. There are the edible dogs with fat body, which are served as food and reared in large numbers. There is a kind from the Western Foreign [country], low, small, clean and cunning, with which you can play; it is called 'ha-pa dog." " $\ddagger$ How the breed came to be produced or originated in Thibet it is impossible even to conjecture. As the Tibetans resembled the Chinese in counteracting the cold by increase in the amount of clothing worn and not by heating the living-rooms, the production of long-coated dogs was natural to the climate. Short-coated dogs would have had but small chance of survival. The association of Manjusri Buddha with a small pet dog, which on occasions was apt to be changed into a lion, may have suggested to the devotees of Lamaism the idea of breeding miniature lions as something of a pious duty, a means of acquiring merit, as well as an indirect strengthening of their creed. The Lamaists themselves say that their Tibetan lion-dogs are bred to resemble lions, and they, like the Chinese, appear to be willing to call any shaggy coated dog a lion-dog.

The first known use of the term "lion-dog" appears to

* Proc. Zool. Soc., 1867.

f "Chinese Pottery of the Han Dynasty," p. 267.

\pm Book XXIV, section on Products, p. $6 b$. 


\section{DOGS OF CHINA AND JAPAN}

refer to a specimen which was probably considerably larger than the Tibetan breed, but which, from the proximity of Northern Kiangsu to Shantung, may have belonged to the race of "lion-dogs" of both large and small species, now found in the latter province.

In the year A.D. II3I, under the rule of the Emperor Kan Tsung of the Southern Sung Dynasty, there lived near Hsuchow, in Kiangsu, a magistrate, Dei Yen Cheng, to whose judgment was submitted the following case, having points in common with that in which Richard Macaire was brought to justice by the dog of Aubry of Montdidier, and with Plutarch's story of Capparus, watchdog of the temple of Esculapius at Athens.

"In a lonely temple twenty li from the city dwelt a priest and his one servant. He had two pets : a cat, upon which he lavished much care, and a dog which was well-known on account of its being a "lion-dog." It happened one day that, during the absence of the servant, who had been sent to buy salt, the temple was entered by a robber, who murdered the priest and got away. He was silently followed by the dog to his retreat whence, after two days, he made for the city, still followed by the dog. Upon reaching a frequented place the dog attacked him and would not be beaten off. When at last he gained the city, the dog again attacked him, barking furiously. The dog was recognized as belonging to the priest, and the vehemence of its attacks was such that the murderer was questioned on the point, and failing to give a satisfactory explanation, was apprehended and, by the dog's guidance, taken to the temple. There the priest's body was found, guarded by the cat: The murderer was taken to the city, tried by the magistrate and executed on full confession of his guilt.*"

$$
\text { "Yuan Chien Lei Han (quoting from the "Yi Chien Chih"). }
$$




\section{THE CHINESE LION DOG}

It is interesting to note that the West too had its "liondog." This breed of small pet dogs was mentioned by Buffon, and Linnæus, writing about $\mathrm{r}_{792}$, enumerates in his list of breeds of dogs the Canis Leoninus or " Lion Dog," said to have a long ruffle on the forepart of his body like a [male] lion, the hinder part growing short hair only. The breed existed in England as early as 1615 , ${ }^{*}$ but certain characteristics were artificially imparted to it, for we read in the Proceedings of the Zoological Society, "Some of the figured and named varieties, as the Lion-Dog ("Chien-lion," Buffon); "Canis familiaris leoninus," Gmelin), are described from dogs that had been artificially prepared." $\dagger$

The Tibetan lion-dogs as existing at present in Peking are in some specimens as diminutive as the common "Pekingese," but are normally somewhat larger. Chinese breeders distinguish two varieties, the ordinary or "Nao-t'ou" (shock-headed), whose face is remarkable for the sticking out of its long coat from the lips and the bridge of the nose, giving an appearance similar to that of the griffon Bruxellois, and the "Tou-t'ou," very rare, whose forehead only is shaggy, the lower part of face being short-haired. The character "Nao" is translated " a large monkey, very nimble in climbing." $\ddagger$ Laufer quotes from the description of the metropolitan prefecture of Shunt'ien, "A small and alert class are the

* "The House of Lyme," by the Lady Newton. There is, however, no known relation between the two breeds.

† Dr. J. E. Gray, F.R.S., Proc. Zool. Soc., 1868.

I The term applied to a dog is considered by the Chinese to be inapplicable to either a very small or a very large dog. The character consists of radicals, one of which means "dog" and the other "soft" or "fluffy," with obvious reference to the coat. Two characters occur in the "Chou Keng Lu" (Yuan Dynasty), and also in the "Pen Tsao Kang No" (Ming Dynasty). "The lion is tawny (lit. yellow-coloured), like the gold-coloured "nao dog." "The same authority says (vol. li, part ii, p. 23), "therc is an animal called the 'nao'; one half of the character means ' $\operatorname{dog}$ ' and the other half ' soft-coated.' . . . Long-coated dogs are called ' nao dogs.'" 


\section{DOGS OF CHINA AND JAPAN}

' $\mathrm{Hu}$ ' (trans. Turkish) dogs which nowadays are called ' ha pa' dogs. There is also the name 'pa'rh' dogs. The longhaired among them are designated 'monkey-lion dogs' (' nao,' a long-haired yellow monkey). The people of the locality call it "shih nung kou."' *

It is to be noted that none but a literary or artistic Chinese would call the ordinary "Pekingese" or the short-coated pug by the name "lion-dog." This confusion of names is similar to that which exists in England in relation to the "Happa" dog-a name which to a Chinese is generic and simply indicates a lap-dog, which may be of pug, lion-dog, or "Pekingese" variety. Chinese breeders of these small dogs would no more confuse the names than a European breeder would confuse the English greyhound, the Italian variety, and the Borzoi.

The Chinese lion ("Shih-tzu ") dogs are longer-nosed than the flat-faced "Pekingese." Perceval Landon remarks that in Tibet itself the Tibetan "terrier" is " a long-coated little fellow with a sharp nose, prick ears, and, as a rule, black from muzzle to tail, found but seldom in a pure state." $\dagger$ They may be of any colour, but must be strong in bone, short-legged and large-eyed. Like the Chinese Chow-dog, they are affectionate to their own masters, but shy and distrustful of strangers. In China, the breed is nowadays sometimes crossed with "Pekingese" with a view to introducing length of coat into that breed.

The Empress Dowager found great difficulty in rearing the Tibetan dogs, which are somewhat delicate, being very susceptible to pneumonia, and require more care than the race usually known as "Pekingese."

Lion-dogs are figured in old Chinese pictures in con-

$$
\begin{aligned}
& \text { " " Book L, p. } 28 a \text {. } \\
& \text { + " Lhasa," Perceval Landon, p. } 387 .
\end{aligned}
$$




\section{THE CHINESE LION DOG}

ventional style. Chinese painters no doubt found it rather beyond their powers to reproduce the shaggy face and to give expression to a specimen which, in the best of the breed, is so compact and long-coated that it is sometimes difficult to distinguish head from tail. 


\section{CHAPTER XIII}

\section{TOY DOGS IN CHINESE ART}

$\mathbf{N}$

Chinese writer appears to have thought it worth while to record the precise points of the pet dog of his day. The most important evidence obtainable on the exact characteristics of the ancestors of the "Pekingese" breed has to be gleaned from such illustrations on paper, silk, porcelain, or lacquer as are obtainable, and from the very rare modelled or sculptured reproductions of true dogs. It is, however, easy to over-estimate the importance of these illustrations. As regards paintings on porcelain it must be remembered that the pictorial work was carried out near the potteries at Chin Te Chen in Kiangsi Province, 700 miles south of Peking. It is unlikely that the pottery artists themselves ever saw the dogs they portrayed. They were working from either verbal descriptions or pictures. In addition to this there were difficulties of reproduction of colour and form on porcelains usually made and painted by hand for cheap wholesale consumption.

Pictures upon silk or paper are commonly imitations of the work of old masters, sometimes honest, but very frequently made with fraudulent intentions. They have the characteristic, remarkable to the European mind, of portraying in a conventionally fixed manner. Modern Chinese painters are so much slaves to style that a picture of some particular tree or rock will often be nine-tenths the tree or rock of an old I 88 


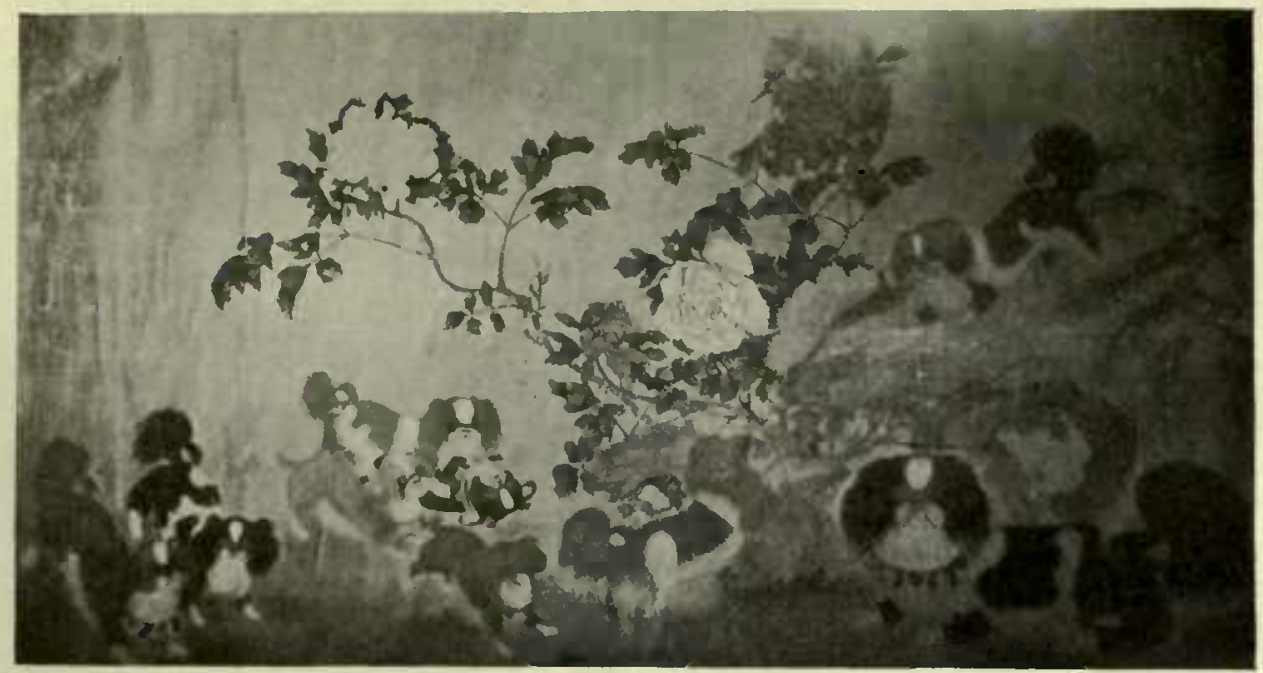

CHIU SHIH TOONG CHÜ. PROBABLY TAO KUANG PERIOD

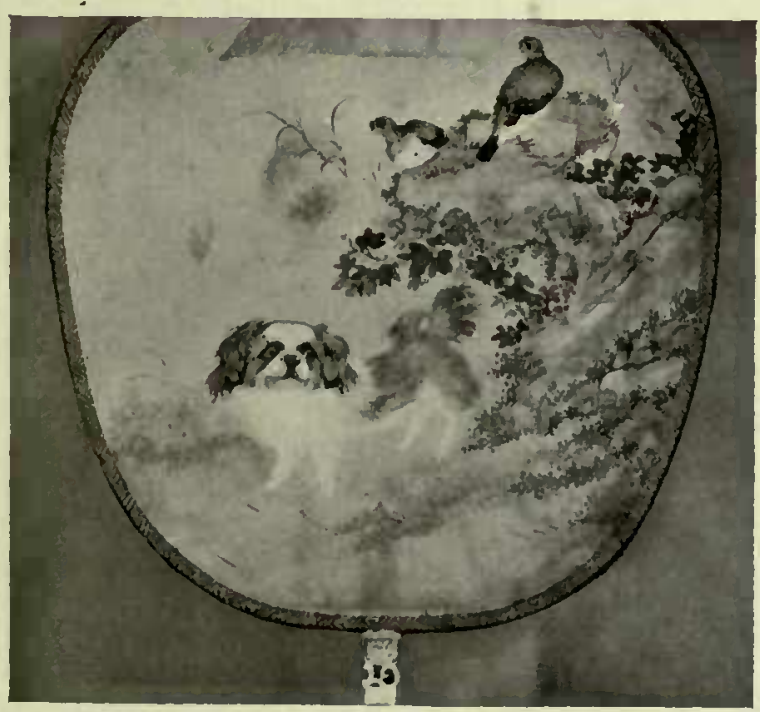

FAN (HSING KE T'U)

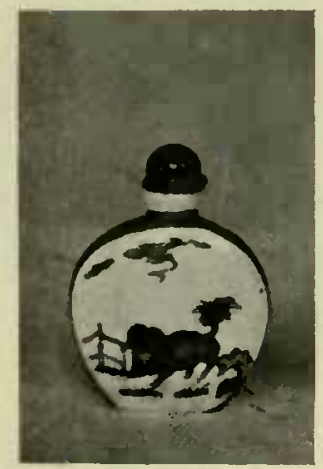

PORCELAIN SNUFF BOTTLE

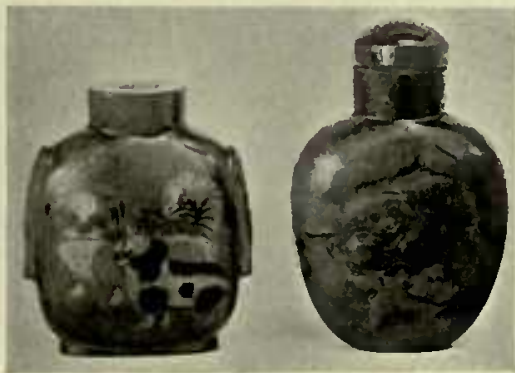

AMBER SNUFF BOTTLES WITH INTERIOR PAINTING

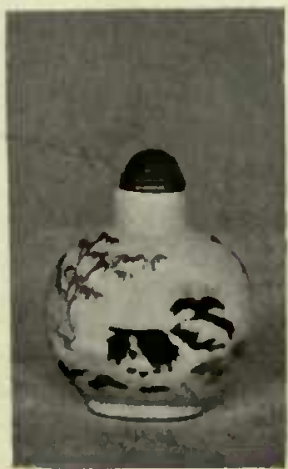

PORCELAIN SNUFF BOTTLE TAO KUANG PERIOD To face p. 188 



\section{TOY DOGS IN CHINESE ART}

master, and will be allowed only one-tenth of the characteristics of the actual subject.

It must be mentioned that modern Chinese artists and picture dealers are the most inveterate imitators, counterfeiters and forgers in the world. The western collector usually falls an easy prey to their deceptions, which can only be guarded against by the closest of specialized study. Some years ago Frau Olga Wegener collected several pictures of the famous local breed of dogs in Peking. The Wegener collection was exhibited in Germany, and a small, but very inaccurate catalogue issued. The collection was acquired in part by the British Museum, and, in consequence of this, too much reliance has been placed upon the statements of the collector regarding the authorship and dates of the pictures. As regards other collections, it appears more than possible that the Sung Dynasty (thirteenth century) "Pomeranian Type of Dog," * by Mao I in the Fukuota Collection at Tokyo, is genuine. No authentic painting of Pekingese dogs older than the eighteenth century is known to exist outside the palace in Peking. The Wegener pictures, ascribed to Shen Chen Lin and said to date from 1700 , are obvious counterfeits of recent date, for there has been only one wellknown Chinese painter of this name, and his pupils now living in Peking testify to the fact that he died only thirteen years ago. Chinese pictorial art has been almost dead for two hundred years, and to this fact must be ascribed the paucity of Chinese animal paintings showing individuality and artistic merit. The Chinese pictures are, for the most part, not portraits of individuals, but they more nearly represent the artist's idea of type.

The eunuchs of the palace endeavoured to obtain type pictures to which they might refer in the effort to improve

" "Toy Dogs and their Ancestors," p. 284. 


\section{DOGS OF CHINA AND JAPAN}

their breeds, and consequently they caused scrolls portraying large numbers of dogs to be painted. Unfortunately, the painting talent upon which they could draw was limited, so that the results cannot compare with those which would be obtained if, for instance, British painters were commissioned to portray a similar number of specimens to be found in England at the present time.

A well-known Chinese painter of dogs in Peking-he had been for years a pupil of Shen Chen Lin-was asked to make a likeness of water-colours of one of the local Pekingese specimens. The result was recognizable as referring to this dog on account of facial resemblance which, apart from somewhat conventional treatment as regards the cheeks, went far to constitute something of a portrait. The treatment of the body, however, was altogether conventional. The fringes of the dog's front, ears, legs, and tail, were almost entirely omitted, and the painter had obviously substituted the crystallized Chinese artistic convention, as it had been transmitted to him, in place of a true likeness of the general form.

Miss Carl, who painted the late Empress Dowager with her two Pekingese dogs, remarks that the "Old Buddha" considered it more remarkable that these animals had been painted so that they were recognizable than that a good likeness of herself had been made. It is probable, therefore, that only a small proportion of the reproductions of these dogs in Chinese art can be taken to be portraits or to have more than an approximate resemblance to definite originals.

All Chinese are fond of sending small presents to their friends on auspicious occasions. The literary man loves to send a luck verse or picture having some happy allusion, usually more or less veiled in classical lore, as a charm or omen, to herald good fortune on a friend's birthday or on the New Year. Buddhism and superstition provide him with an 190 




CHINESE BOWL, PEKING

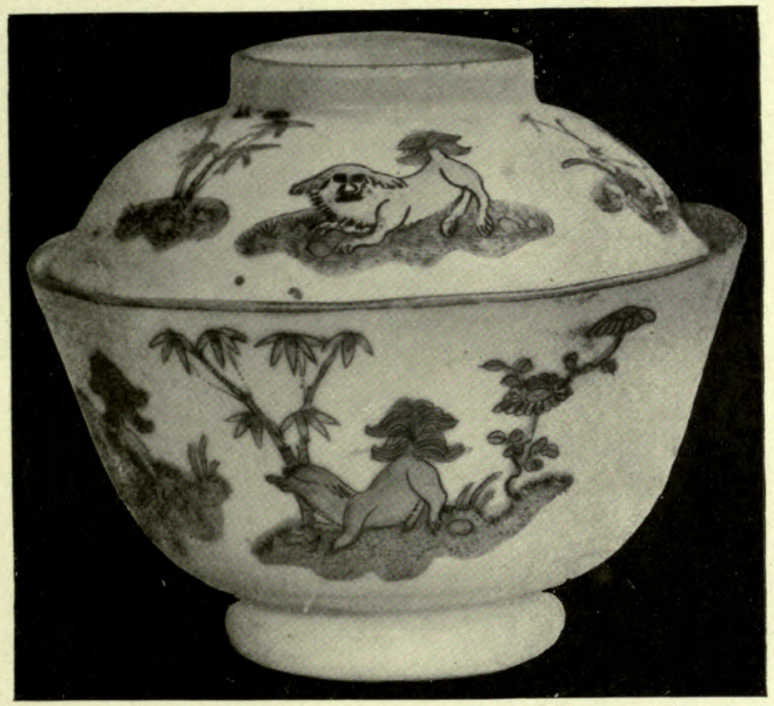

CHINESE TEACUP AND COVER, TAO KUANG PERIOD
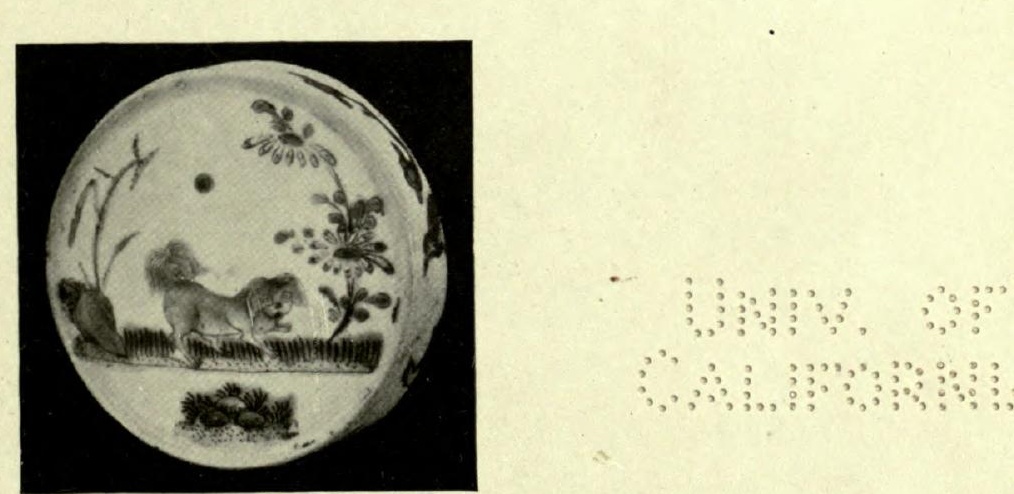

PORCELAIN FACE-POWDER BOX FROM PEKING 
$\because \because \vdots \quad \because \because \vdots \vdots \vdots \vdots \vdots \vdots 0)$

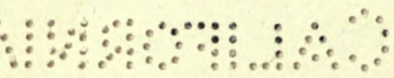




\section{TOY DOGS IN CHINESE ART}

ample fund of allegories and similes upon which he freely draws, and it is to this custom that we owe most reproductions of Pekingese dogs. When the Chinese scholar wished to fit some particular word into a well-turned pictorial phrase, he found keen delight in perversely substituting an object which, by the sound of its name, or by the Chinese character, would delicately suggest the wish of the sender without reducing it to the bluntness of bald prose. If his wish referred to a word sounding like "lion," the cultured men of Peking would be apt, especially if he were favouring one of the "fancy," to picture a member of the small breed of lion-like dogs which give his native city a certain degree of fame. The commonest form of token-presents in connexion with Pekingese porcelains was, at the beginning of the nineteenth century, that of the snuff-bottle. The illustrations always have a distinct meaning, and are usually the pictorial representation of some timely couplet or well-turned lucky phrase. The picture-phrases must be apt allusions and also have literary merit. Some of them can be construed as standing for two or three separate good wishes. They often introduce lucky numbers. A common snuff-bottle illustration, which has an European parallel, is a picture of three magpies-the Chinese name for magpie signifies joy-bird —on a tree with the sun shining overhead. The wish is "One day three joys" ("Yi Tien San Hsi "), such as official rank and a first-born son to a proud father on his own birthday. Unfortunately these snuff-bottles were carried in the pockets of their owners, so that authentic specimens have often lost the freshness of their illustrations through wear of the enamel. The phrases most frequently found illustrated are as follows :

"Huan Tien Hsi Ti."

("Love Heaven Joy Earth.") 


\section{DOGS OF CHINA AND JAPAN}

This antithetical couplet is figured by butterflies flitting above children playing with cicadas or dogs.

A picture of children flying a butterfly-kite is also used to symbolize joy below united with the much-loved "windharp " above. The wish of the sender is, "May the happiness of heaven and the joy of earth give you their united blessings."

Another illustration is that of a "Pekingese" dog looking up at butterflies floating above him. The dog is here symbolical of joyful affection, and the butterfly of heavenly bliss.

Another illustration commonly found is that of an old man with a dog pictured on one side of a snuff-bottle and a child playing with two Pekingese dogs and a butterfly on the other. The wish is, "May old and young live together in happiness."

It will be recalled that, according to Chinese custom, probably a survival from tribal days, all the male line of a family inhabits one house or collection of houses so long as a parent or grand-parent of the family remains to link them with the past. On account of the survival of polygamy in China, and the slender years of the average Chinese bridegroom, this custom is productive of frequent trouble in even the best regulated of households, so that in the East a delicately expressed hope that old and young may live together in peace and happiness is even more often appropriately auspicious and more intensely a heartfelt wish than in the West, accustomed to the doctrines of monogamy and the unit-home.

Two other lucky couplets found on "Pekingese" snuffbottles throw a sidelight on this Chinese family custom.

Chiu Shih Toong Chü.

Nine generations together live.

("May nine generations live together in peace.") 


\section{TOY DOGS IN CHINESE ART}

History stated that the Sung Dynasty was able to boast the remarkable circumstance of nine generations in one family of the name of Chang living under the same roof in peace and quietness. This wish is often imparted to the recipient by means of a picture of chrysanthemums and "Pekingese" dogs or lions. There may be simply lions or dogs, nine in number, representing a pun on the word "generations," which in the vernacular has approximately the same tone. The Chinese for chrysanthemums in Peking vernacular is "Chiu-hua," literally " nine flowers," on account of their flowering in the ninth moon.

\section{Wu Shih Toong T'ang.}

("May five generations live together in the same home.")

The feat performed by the Chang family is considered, even among the peace-loving Chinese, to have been so extraordinary that in the present age of drooping filial piety a minor wish is sufficient to express the utmost good augury conveyable in a polite hope. The wish is usually pictured by means of one big and four small lions. Snuff-bottles picturing five "Pekingese" dogs and expressing the same wish are also found.

In the Chow period, which dates from about 1000 B.C., the highest literary degrees ("Imperial Instructor ") were six in number and were divided into two classes, the chief of the first being the "T'ai Shih," and of the second the "Shao Shih." The meaning is " may you attain the higher grade of Imperial Instructor, or at least the lower." This picture is very frequently found on Chinese porcelain dating to the beginning of the nineteenth century, in which the phrase has become a little less apposite on account of a slight change in the chief literary titles.

Other pictures allude simply to some historical incident or 


\section{DOGS OF CHINA AND JAPAN}

to a trite saying. That most frequently found is perhaps the following :

This motif symbolizes the superiority of man's wit over brute force, and conveys an antithesis such as that found in the English proverb, "The pen is mightier than the sword."

This is usually represented by a pair of "Pekingese " dogs playing together, and forms an appropriate present from a husband to a wife naturally fond of dogs. The idea expressed is "May we live together in united joy."

The chief hobby of the Emperor Tao Kuang (1821-1850) was the breeding of pigeons. The Empress had a favourite and very celebrated "Pekingese" dog which on account of its colour was named Hsing-erh (apricot) and had a white button upon its forehead. This picture is by far the most frequent in connexion with illustrations of "Pekingese" dogs, whether on paper, silk or porcelain. It was favoured by loyal Chinese of the Tao Kuang period as flattering the exemplary devotion shown by the Emperor to his wife. The breeding of pigeons is universal in China. The flying of them with whistles attached is almost as much a national pastime in China as the flying of kites. The picture has special appropriateness on account of its being an expression of the other lucky phrase : "Love in heaven : joy on earth." A wish for united blessedness also exists, for the first half of the Chinese character for the word " pigeon " introduces the connotation "fit" or "appropriate" in the sense of "well-matched."

Shortly before I89I the Empress Dowager's chief eunuch, Yin Liu by name, lost his three favourite "Pekingese" dogs by a fire which destroyed the house in which they were kept. These dogs were named, Sung To (" pine cone"), a black and white dog; Chu Yeh (" bamboo leaf"), a red and white or yellow and white dog; and Mei Hua ("plum flower"). I94 


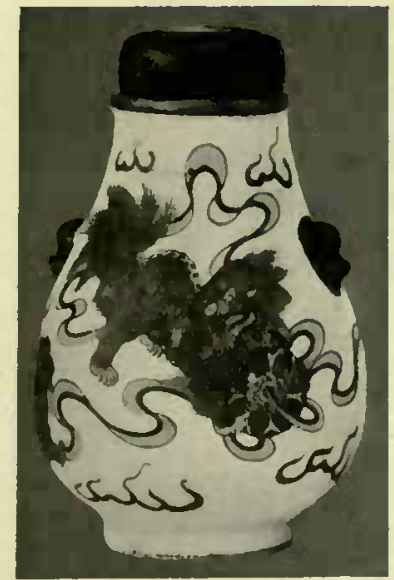

PORCELAIN SNUFF BOTTLE FROM PEKING

SHIH-TZU KUN HSIU CHIU. LION ROLLS FMBROIDERED BALL

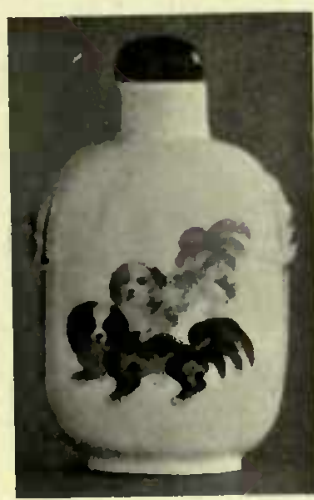

CHINESE SNUFF BOTTLE (TAI SHIH, SHAO SHIH). TAO KUANG PERIOD

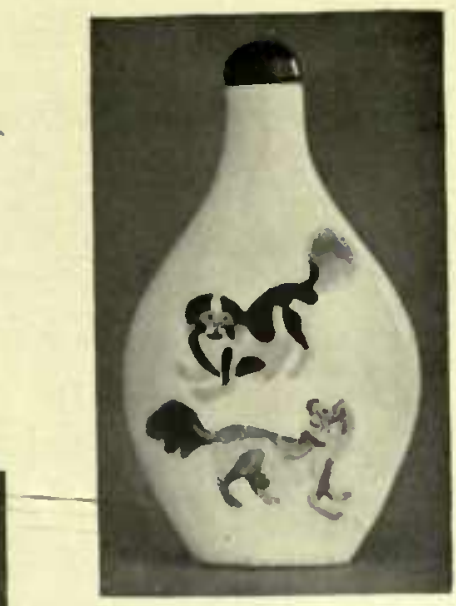

CHINESE SNUFF BOTTLE (TAI SHIH, SHAO SHIH). TAO KUANG PERIOD

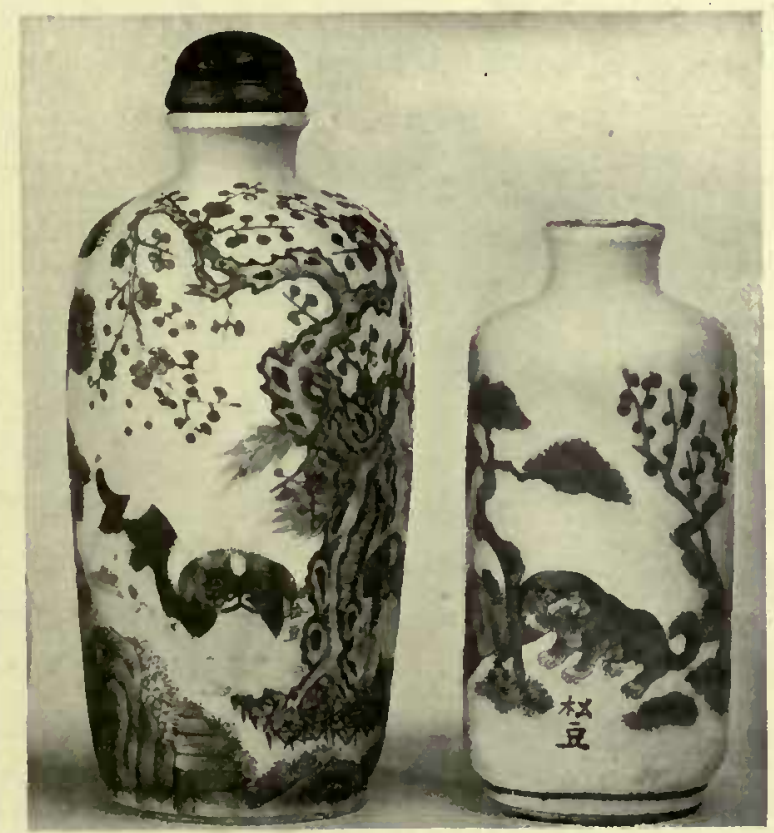

CHINESE SNUFF BOTTLES (RECENT) SAN YU T'U (THREE FRIENDS PICTURE) 



\section{TOY DOGS IN CHINESE AR'T}

In memory of these dogs he caused to be made circular porcelain snuff bottles of large size. Upon them is pictured in five-coloured enamel a representation of these three dogs, each with its name, together with a pine-tree, a plum-tree, and bamboo branches. These three trees are found on other snuff-bottles without dogs.

Now Confucius said, "In winter the pine-tree does not shed its leaves." To Confucians the pine-tree is therefore symbolical of stability under adverse conditions.

The plum-tree and the bamboo are considered symbolical of the same idea of fidelity under adversity to the Chinese, because it is in winter that the plum-tree flowers, while the leaves of the bamboo remain green throughout the cold season. This picture presented to two friends would bear the sender's wish :

"Through fire, or the winter of adversity, may our friendship remain as full of life as the pine, the bamboo, and the plum-tree." 



\section{INDEX}

A-CHEE, ceremony of, 27

Acheen, king of, 74, 75

Adams, Will, 174,175

Aigun, dogs of, 149 and note

Ainu, the, 24, 25, 71

Ajmere, king of, dogs sent to, 81, 82

Albrecht, Oscar, 10 note

Alcock, Sir Rutherford, 177

Alexandra Palace Dog Show, 1875,85

Algonquins, dog superstitions, 78

Alpinus, C., varieties, 5,6

Alva, Duke d', 167

Ama Inu, the, 117

Amacia, Acterius, Bishop of, 144, 145

Amoy, trade of, 139

Anahita, 95

An-hsi, lions from, 91

An-hui, dogs of, 7 I

Anne, Queen, presents of dogs, 47

Anon, book of, representations of falconry, 64

Anubis, II, 102

Ao, dog of Leu, 8, 9, 15,76

Aristotle cited, 144

Arkwright, W., "The Pointer," 65

Aryans, dog-veneration by the, 12, 13 , 31,36

Asoka, lion-worship under, 95,96

Assur-bani-pal, bas-reliefs of, 12

Assyria, the lion in, 94

Assyrian dogs, 12 ; dogs of Asshurbani-pal, 77 note

Assyrian lions, 122

Astronomy, Japanese, symbol of the lion, 117

Atargatis, goddess, I I 3

Athenodorus, cited, 144

Avignon, dogs of, 49

BAI dog, the, r 30 note

Barking deer, 80

Bas-reliefs, rubbings taken from, 6r, 62 ; of the Han period, 72
Batavia, 176

Bell, "Travels in Asia," I4I note

Bernard of Clairvaux, Saint, 38

Beyamini, 79 ...

Bicknell, Ethel E., 69 note

Birch, Dr. S., quoted, 9 note

Black dogs, markings, 163,164

Blenheim Spaniel, the, 156 ; the " spot," 161,162 ; points of distinction, 168

Boar-hunting, 56, 57

Bogaz-Keui, sculptures; I 3

Bologna, 146

Bonvalot, G., "Across Tibet," 84

"Book of Rites," reference to, 23, 29, 30, 44, 5 I

"Book of the Five Elements," 48

Borzoi dog, the, 75

Bours, Madame du, request for poodles, 45

Bower, "Across Tibet," 84

Boxer rebellion of 1900,153

Boyle and Manning, "Tibet," 83

Brassey, Lord and Lady, I 70

Breeding. See Dog-breeding

Brinkley, Capt. F., "Japan and China," $1,2,17,115$

Britain, dogs of, sent to Rome, 16 ; dog's flesh used by cave dwellers, 24

British dogs, renown of, during the Stuart period, 44

British Museum, MSS. representations of falconry, 64; the Wegener collection, 189

Buddha, distinguished from the human race, I2I; his thirty-two superior marks, 161,162

Buddhism, laws of, $27-29,116$, I 17 ; animal superstitions, $38-40$; introduced into China from India, 91, $92,95-97$; introduced into Tibet, 181

Buddhist lion, the, 92, 95, 96, 98; depicted, I04, 107-III, II 4 


\section{INDEX}

Budge, Wallis, "The Gods of the Egyptians," 94, II3

Buffalo stories, $105-107$

Buffon, "Histoire Naturelle," 7r, 150, 185

Bull, the Assyrian, 107

Bull-baiting in England, 45, 46

Burgess, "Buddhist Art in India," 98,121

Burgundy, Duke of, 73

Burial ceremonies, the dog in, 78,79

Bushell, "Chinese Art," 90, 128

Byzantine Empire, China and the, 128 , 146

Chesar, Augustus, and the ram, 3 I

Cæsar, Julius, on dogs, quoted, 15

Caius, Dr., quoted, 69 note, 84, 145

Camuses, 167 and note

Canton, sale of dog flesh in, 26, 27 ; trade of, I 39

Carl, Miss, in Peking, 53, 152, 153,190

Cat-rearing in China, $135^{-1} 37$

Cats, arrival in England, 2; legends concerning, 40,41 ; of the Ming period, 51, 52; Persian, 141 ; imperial popularity, I 47

Cave-dwellers, 24, 25

Ceylon, the lion in, 96

Chang Ch'ien, 91, 96

Chang family of nine generations, 193

Ch'ang Hsien, the God, 35

Chavannes, 10; "La Sculpture en Pierre en Chine," 72

Chen, City of, 14

Ch'en, "Kwong Yun " cited, 17

Chen Tsung, Emperor, 132

Chengtu, 134, 170

Chia Hsiang, 68

Chiao Ch'eng Chi, bas-reliefs, 68

Chiao dog, 8

Chiao-tzu, horn-ear, I 71

Ch'ien Hsi-lin, General, vii

"Ch'ien Lei Han," quoted, 17

Ch'ien Lung, Emperor, 58, 140, 149 , 150

Ch'ih $\mathrm{Hu}$, dog, $\mathrm{I}_{2} 6$

Chili, cats of, I 4 I

Chilin, 47

Chin Chang Hsun, 172

Chin dog, 24, r79, 180

Chin Shih, Emperor, 15, 16

198
"Chin Ssu Ha-pah," 160, 161

Chin Te Chen potteries, 188

China, domestication of the dog in, $4-7$; foreign policy influenced by regard for dogs, $9,10,15$; dogflesh as food, 20-28; the dog in religious ceremonial, 32 ; dog superstitions, 32-36, 40, 4I ; dogbreeding in mediaval times, $47-50$; use of the dog in the chase, 51 ; Buddhism established in, 96, 97 ; lion-masques, 115,116 ; division and reunion of the dynasties, 124, 125; silk trade of, 128; East India Company's trade with, 176

Chinese Art, toy dogs in, 188-195

Chinese dogs, possible wolf-origin, $6-8$; the Heavenly dog, $32-36$; the Imperial breed, 144

Chinese lion, artistic conception, 107-11 1

Chinese lion-dog, name applied to any long-haired dog, 181, 182; compared with the "Pekingese," I 86

"Chinese Pottery of the Han Dynasty," Laufer, 4-6, 56-58, 6I-66, 76, 77, $79,92,95,98$, I 17 note, 183

Chinese sacrificial animals, 29

"Ching-kou," 170

Chou Hsin, Emperor, ro

Chou Po-ch'i, "Diary," 76

Chow, the, flesh used for food 26 ; origin of the name, 58 ; use in fowling, 69,70 ; tongue, 157

Christianity, belief regarding the dog, $3^{8}$

Ch'ung Hua Tihi Ch'uan Chih, quoted, $14^{8}$

Cibot, Père, researches, 22, 23

Clans, Chinese, particular colours in dogs for, $16 \mathrm{r}$

Clay figures, use of, 78,79

Cleves Anne of, dogs, 45

Click, Chinese origin, 169,170

Cocks, Richard, in Japan, 175,176

Colouring, the white spot, 161, 162; tiger-stripes, 164

Colours, the Pekingese, 160, 16r

Condor, C. R., "The Rise of Man," 87 note

Confucius, sayings of, $14,16,168,195$ a cat story, $136-137$ 


\section{INDEX}

Conger, Mrs., dogs presented to, 153

Constantinople, 128; capture by the Turks, 146

Cooper, Mr., cited, 80

Copper period, dog superstitions, 78

Corea, hawking introduced from, 2 ; use of dog's flesh, 24 ; the tiger in, 90 ; the dog of, II7; home of the ethereal lion, II9; dogs sent to Japan from, 172

"Corean dogs," I 18

"Corean purify heart pill," II9

Corpse-eating dogs, 87

Coxinga, pirate, 166

Crested Chinese dogs, 7 I

Cross-breeding, I64, I65

Cunningham, A., "Ladak," 77 note

Cybele, II3

Daimio of Hirado, 74, 175

Dalziel, "British Dogs," 85

Das, Sarat Chandra, dogs mentioned by, $85-89$

Daubenton, quoted, I 50, 151

Davies, "Guide to Heraldry," 108 note

Dawkins, Prof. Boyd, "Cave Hunting," 1,24

Deccan, red dog of the, 6

Deggi district, 8I

Dei Yen Cheng, 584

Dingo, the Australian, 3

"Docking " of dogs' tails, I51, 165

Dog Shows, 51, 52, 179

Dog, the, evolution from the wolf, 2,5 ; wolf-origin of certain Chinese dogs, 6,7 ; use of flesh in China, 20-28; rules for presentation of, from "Book of Rites," 29, 30; a sacrificial animal, 29,32 note; the Heavenly dogs, $33-35$; the hedge-dog, $36 ;$ miniatures in temples, 37 ; superstitions regarding, 42,43 ; punishment for killing, 86 ; included in imperial presents, 177-r 79

Dog-books, imperial, 52, 152, 163

Dog-breeding, political importance of, in mediæval times, $47-49$; methods of development, 53,54 ; commercial, 54,55 ; forbidden in precincts of Imperial ancestral temple, $13^{8}, 139$
Dog-markets in Peking, 153,154

Dog-markings, Chinese superstitions regarding, 47-49

Dog-sacrifices, 29, 32 note, 78

"Dog-whipper," office of, 49

Dog-worship in Egypt, $11,12,117$

Dogs, Isle of, 45,49

Doolittle, Rev. Justus, "Social Life of the Chinese," 35

"Dragon-Tiger Soup," 28

Drummond, Henry, 178

Dudley, Robert, Duke of Northumberland, dogs of, 65

Dunne, Capt., 152

Dutch East India Company, 30, 1 39, 174

Duzaka, the, 36

Ears of the "Pekingese," 158

East India Company, trade with Japan, $46,174-176,178$; export of dogs through, $74,8 \mathrm{I}-83$

Eckl, Herr B., "Sacristy," I 12

Eclipse, Chinese superstitions regarding, 32-34

Egypt, dog-worship in, I1, 12 ; hairless dogs of, 71 ; lion-worship in, 94; mythology of, 112-117, 120; sun-worship, 120

Elastic skin, 164

Elgin, Lord, 30

Elizabeth, Queen, presents of dogs by, 45,125

Elliott, G. F. Scott, "Prehistoric Man and his Story," $3,4,78$

Embassies, Sham, 139, 140

Empress Dowager, dog-breeding by, 150-153, I 57,186 ; tail-docking, 165 ; visit of the Dalai Lama, 182, 183 ; dogs, 190; pigeons, 194,195

"Encyclopædia Britannica," the, cited, 12,103

England, breeds in, 5I, 52 ; trade with China, 139

Erh Lang, the God, legends of, 32 ; dog-worship in temple of, 35-37

"Erh Ya" quoted, $7,16,64,76$

Esquimaux, sledge dogs of the, 71

Ethiopia, dog-worship in, 12

Eunuchs, dog-breeding by, 164, 165

Europe, dog-breeding in mediaval times, 46,47 ; lion-dog of, 185,186 


\section{INDEX}

FalconRY, in Europe, 62 ; in China, $62,64,68$; in Japan, 64

Faust, 40

Fei Ti, 18,19

Feng Shui, practice of, $40,47,90,162$

Fennel, on the King Charles Spaniel, cited, 177

Fenollosa, "Epochs in Chinese and Japanese Art," I 25

Fernam Mendez Pinto, 20

Fleming, Abraham, 69 note, 145

Firando, English factory at, $174-176$

Fire-worship, the lion associated with, I20, 121

Five elements, superstition of the, 42 , 43

Fo, lion of, II5

Foism, the lion in, 96, 100

Folin. See Fu-lin

Foochow, 35

Foot-binding among Chinese women, 137,138

Formosa, trade of, I 39

Fortune, Robert, " Kaempfer," 25, 26, $30,31,37,3^{8}, 64, x \times 8,173, x 74$; on lap-dogs, I79; "Visits to Japan and China," 180

" Four eyes," epithet, 162,163

Fowling piece, use of the, 62, 68, 69

Francis of France, 44

Franciscans, the, 134

Francolin, the, 68, 69

Fraser, Mrs. Hugh, "A Diplomatist's Wife in Japan," 180

Frederick II., 62

Fu Lin or Fo Lin, dogs of, $117,127-129$, $14 x, 143,146$

Fukuota College Tokyo, 189

Funeral ceremonies, Tibetan dogs in, 87,88

Fung Shen Bang, "Popular Book of Superstitions," I1 4 note

\section{G. palustris, 3}

Gabriel Hounds, the, 40

Game Laws, modern, unknown in China, 59

Gaudhara, Court of, 92

Geikie, Prof., "Geology," 2

Genghis Khan, 97

George III., $5^{8}$

200
Goa, capture of, 173

Goldfish, Chinese breeding, 52

Goshawk, use of the, 66,68

Gray, Dr. J. E., cited, 54,185

Gray, J. H., "China," 26, 27, 33, 34, 42

Great Britain, trade with Japan, 174I 76

Greece, the lion in, 95

Greek art in China, 97, 98, 112

Greeks, dog-worship by the, II

Greenwich Palace, 45,49

Gregory XIII., Pope, 173

Greyhound, the, in China, 72-75; in Europe, 72 ; the small, 75 ; measurements of specimens, 75

Greyhounds, depicted on the Han pottery, 56-58 ; export of English, 73, $74 ;$ Irish, 82

Griffis, "Corea : The Hermit Nation," 24, 118

Griffis, W. E., "The Jap Nation in Evolution," 7 r note

Groot, "Religious Systems in China," 42.

"Grosier de la Chine," quoted, 23, 24 , I 4

Grünwedel, A., "Buddhistische Studien," 108 note

Gryphon, the Egyptian, I 10

Guns used in hawking, 68

Gwalior State, last lion killed in, 9r note

HACKNEY horses, 73

"Hah-pah" dog, the, 149, 160, 161, $\mathrm{r} 83,185,186$

Hai-Bah (or $\mathrm{Ai} \mathrm{Bah}$ ) dog, meaning of the term, 138 note

Hairless dogs, 71

Hakluyt Society, "Travels of Peter Mundy," 46 note

Han potteries, relief bands, from Laufer, $4-6,5^{6-58}, 61-66,76,77,79,92-$ 95,98, I 17 note, 183

Handcock, Percy S. P., cited, 12, $4^{8}$ note

Hangchow, 132, I 34

Hares, taken with hawks, 66,67

Harrison, cited, 146

Hastings, Warren, 98

Hawking, introduced into Japan, 2 ; in China, $65^{-68}$ 


\section{INDEX}

Hawk-training, Chinese and Japanese methods, 62

Hay, Lord John, I 52

Head, the, importance in breeding, 155,156 ; the term "appleheaded," 156

Hearn, Lafcadio, 25

Heavenly dog, the $33-37,72,117$

Heber, Bishop, 91 note

Hedge-dog, the, 36

Henrietta-Maria, dogs of, 47

Henry VIII, presents of dogs, 44, 45 ; "Calendar of State Papers," 60

Heraldry, the lion in, 103, 107-I II

Herodotus, cited, I I, 12

Hertford, Lord, 65

Hewitt, J. F., Fournal, 32 note

Hinduism, legend of Manu, 28, 29; legend of the Heavenly dog, 36, 37

Hippocrates, cited, 23

Ho Hsi Min, "Kuang Shih Lai Fu," 130

Hodgson, Mr. Bryan, "Drawings of Nepalese Animals," 83, I82

Holborn Horse Repository, dog show 1862,179

Holditch, Sir Thomas, "Tibet, the Mysterious," 39, 40, 81 note, 87 , 118

Hozan, lion-worship at, 106

Horse-sacrifice, 29

Hosie, Sir Alex., cited, 55

"Hou," mythical animal, 157

"Hou Han Shu," quoted, 17

How Tien Ch'uan, the, 34, 35

"Hsi ch'ing ku chien," the, 4

Hsi Tsoong, Emperor, I 31

Hsi Yang Mintzu, greyhound, 75

Hsia-kwei, dogs of, I 49

Hsianfu, 128, 132, 147

Hsiao T'ang Shan, bas-reliefs, 61, 62, 64

Hsien Feng period, 151, 165

Hsien, the, definition of term, 7

Hsi-kou, the, 72

Hsin Lo, dogs from, I 3 I

Hsiung nu, dogs of, 8

Hsu Shen, "Shuo wen," I7

$\mathrm{Hu}$, dogs, 186

$\mathrm{Hu}$ Kuo Ssu temple, $\mathrm{I} 53$

Huang $\mathrm{Ti}_{1} 4$

Huish, "Japan and its Art," 179

Hung Wu, Emperor, 146
Hunting, Chinese, with dogs, $8,9,15$, 50 ; description of an imperial hunt, 93; under the Manchus, 148 , 149

Huo Bin, 96

Hydrophobia, 88, 89

IBN Batuta, cited, 20

Idstone, quoted, I8o

Iennet, the Spanish, 64

Imperial instructors, 193

Incense-burners, lion-shaped, 12 I

India, decline of Duddhism, 97

India art, the lion of, 108 note

Indo-Persians, 119

Islam, exclusion of dogs, 11, 12, 125, 128,129

Ismayloff, Embassy of, 141 note

Iyeyasu, Emperor, 179

JAPAN, non-use of dog's flesh, 24, 25 ; street dogs of, 25, 26, 30, 31; British trade with, 46, 74, 174, 175 ; lion masques, 115, 116; symbol of the lion in astronomy of, II7; lion supports for imperial throne, 118 ; presents of dogs from China, 172; trade relations with Portugal, 173,174

Japanese dogs imported into England, 179,180

Japanese toy dog, the, 146,147

Jalandhara, Council of, 96

James I., ban on tobacco, 16 ; dogs of, 46,47 ; dogs sent to the East by, $74,75,81,82$; on Japan, 175

Jäschke, quoted, 7

Java, dogs of, 3

Jesse, "Anecdotes of Dogs," 166

Jesuits, the, 139-14I, 147

Jew, the, prejudice against dogs, II, I2

"Jih Hsia Chiu Wen K'ao," 134 note, 141 note

Jingu, Empress, 118

John, Mrs. St., I 70

Johnson, R. Campbell, "Semitic Magic," 95

Johnston, the "Elian," 129

Johnston, on the Maltese dog, 145

Joyce [Peru] "South American

Archæology," 9 note

Judah, lion of, 120

"Jui ying t'u," quoted, 8 


\section{INDEX}

Jung, the, 6

Juvenal, 34

KAEMPFER, cited, $30,31,37,38,64,118$, $173,174,179$

K'ai Fu, title, I 8

Kamakura, court, I7

Kan Tsung, Emperor, 184

Kang Hsi, Emperor, hunts of, 92-94; dictionary of, $\mathrm{I} 30$; pictures of, 133, 134; embassies to, 140, 141 ; dogs of, I49, I5 I

Kansu, the small greyhound, 75

Kao Wei, Emperor, story of, 126, 127

Kathiawar, lions of, 91

Katmir the watchdog, 125

Keller, C., ro note

"Keng-hsien," meaning of term, 23

Khri-Srong-Ide-tsan of Tibet, I 81

"Kin Shih So," 68

King Charles Spaniel, the, points, 156 , 168 ; possible Eastern origin, I77

Kinsen, Emperor, veneration for the dog, 30, $3 \mathrm{I}$

Kircher, Athanasius, cited, 140, 148 ; on Chinese foot-binding, $137, x_{3} 8$

Klementz, 62, 63

Knife-cut mouth, the, $155,{ }_{5} 6$

Ko chih ching yuan, 14 note

Koma Inu, I 17

Kou Tzu, Emperor, 127

Kublai Khan, dogs of, $50,5 \mathrm{r}, 80,93$, 144; lions of, 92; Lamaism adopted by, 97 ; fall of, 135 ; conquests, I $8 \mathrm{I}$

Kungpah T. King, Mr., vii.

Kupang, chiefs of, 25

Kyushu, island of, 173

LAMA, the Dalai, 118,148

Lama, the Grand, 97 ; the Teshoo, 83 , 99 note

Lamaism, the lion in, 96, 97, 100, 103, 106, I 8 , I I9, 121, 122; teachings regarding the symbolism of the lion, II2, II3 ; under the Manchus, I 48,149

Landon, Perceval, Lhasa, 71, I86

Lap-dog, cult of the, 52, I49

Laufer, Bertold, "Chinese Pottery of the Han Dynasty," 4-6, 56-58, $6 x-66,76,77,79,92-95,98$, Ix note, 183 ; on wolf-origin of some Chinese dogs, $6-8$; on the ha-pa dog, 185,186

Lauriya pillar, the, 95,96

Layard, cited, 77 note

Lee, " Modern Dogs," 179

Legge, "Chinese Classics," 9, 10, 34

Leo, Constellation of, not known to China, 90, 120

Leo, the Isaurian, 128

Leopard, the Chinese, 85

Leu, tribe of, 8-10 ; dogs of, 15

Lhasa, ceremony of the scapegoat, 39, 40 ; founded, $18 \mathrm{I}$

Lhasa terrier, the, $18 \mathrm{I}$

$\mathrm{Li}$ Chih, poet, 133

Lien, the, definition, 7

Linchinchow, cats of, 137

Lin-ching, 137

Ling Ti, Emperor, 18, 124, 126

Linnæus, list of dogs, 185

Lion, the, dog-lions, 97,98 , IOI, I 46 ; guardians of tombs, 118 ; Chinese superstitions, I18-120; characteristics of Buddha possessed by I 2 I, I 22

Lion, the Buddhist, 92, 95, ror ; symbolism of, I 32 - I I 5

Lion, the Chinese, not indigenous, 90, 91 ; the Chinese artistic idea, $91,92,97,98$

Lion, the Heraldic, I03, 107-1II, I16, II7

Lion, the Lamaist, description, 96, 97 ; characteristics, 121,122

Lion, the Spirit, 97, 98, ror

Lion, the Tibetan, 99; Buddhist representations, 100, ror

Lion-dog, breeding of the Tibetan, 53 ; first Chinese mention of, 144 ; first known use of term, 183,184 ; the two varieties, $183-185$

Lion-masques, I I 5 , I 16

Lion-pillars, 95

Lions' milk, legend, I 8 , I 19

Lion-stories, Buddhist, 101

Lion-worship, origin, 91, 94-96 ; stories, 106

Li-poo Board, Pekin, 33

Lisle, Lady, poodles, 45

Liu Jou Yü, 135

Lo Yang (Honanfu), 18 


\section{INDEX}

Lo-chiang dog, the, $131-134,146,147$ 168-17I

Lockhart, Dr. W., cited, $84,147, I_{3}$

Logon Gyalpo, the, 39

Long-dog, the, 72

Loong chua lo-sze dog, I7I

"Lo-sze," the term, 168, 169

Lung Fu Ssu Temple, dog-market in, I 52-1 54

Lyons, dog sale at, 146

Lytton, Hon. Mrs. Neville, "Toy Dogs," I5, I29, I44-146, I68 note, 177,189

MacAo, 92, I73, 174,179

Macartney, Lord, in Peking, 142, 150

Macgowan, Dr, on the Chinese cat, 136,137

Mahomedanism prejudice against the dog, I1 $12,125,128,129$

Malta, I44

Maltese type of dog, I25, 129, I43-146 ; Daubenton on, $15^{\circ}$

Man Chu Hsi $\mathrm{Li}$, name applied to the Manchu emperors, 148

Manchu emperors, love of the hunt, I 48, I 49; wearing of pearls by, I62; Tibetan presents of dogs to, 182

Manchuria, commercial dog-breeding, 54,55

Mang, the, 7

Manila, 139

Manjusri Buddha, the, $148,149,182$, 183 ; the harnessed lion of, 163

Manning, 87,88

Mantua, Marquis of, 44,46

Manu, legend of, 28, 29

Mao I., I 89

"Mao Shih Ming wu t'n Shuo," quoted, 6,7

Maori, mythology of, 120

Marignolli, cited, 102

Mark, St., lion of, II6, II 7

Marsden, "Travels of Marco Polo," 4I note

Marten, the, 144

Massey, G., "Book of the Beginnings," II 7 note, 120 note

Mastiffs, British, breeding of, $44-46$; presents of, to the East, $81-83$; compared with Mongolian, 85
Mastiffs, Tibetan, $60,61,76,77,79-81$, 83

Maunserore, Lake, 99

Melita, dogs of, I 44, I 45

Meng hai, I 4

Miaco, $179^{\circ}$

Mikii, C., 2, 3

Milan, Duke of, 73,74

Ming Kung Shih, 136

Ming period, cats of the, 51 ; dogs of the, 129, I35, I47; foreign trade during, 139

Ming $\mathrm{Ti}$, Emperor, 96

Minns, "Scythians and Greeks," 120 note

Min-tzu, 72

Mithras, worship of, $102, \mathrm{IO}$

Mongolia, eating of dogs' flesh in, $2 \mathrm{r}$, 22 ; commercial dog breeding, 54, 55 ; sledge dogs of, 70 ; wolfhounds of, 75,76 ; mastiffs, 81,85

"Mongrel cur," the, I 68

Montmorency, 45

Moo-Tan, dog, I 53

Moreton, Capt., 177

Mtesa, King of Uganda, ro3

Müller, Max, "Laws of Manu," 28, $29,36,37$

Musk deer, 80

Mythology, Egyptian, connection of the Buddhist lion with, I12-I17, I20

NAGASAKI, I74

Nain Singh, cited, 39

Nao dog, 185 note, 186

Navarette, "An Account of the Emperor of China," 21

Nepal dogs, 83

Nestorians, the, $97, I_{34}$

Newcastle dog show $1859,51,52$

Newton, Lady, "The House of Lyme," 185

Nieuhoff, John, 137

"Nihonji," the, cited, 79

"Nine Generations," the wish regarding, 192,193

Nose of the "Pekingese," 1 56, 157, 168

Noses, artificial production, 53, 54

ODORIC, Friar, quoted, 50, 92

Ogilby, John, "Embassy from the East India Company," 21, 137, 140 


\section{INDEX}

"Old Buddha," 53, 152

Oppian, "Cynegetica," 5 I

Ordeal, trial by, Chinese customs, 2 I, 22

PA-ERH dogs, 149 note, 150

"Pai " dog, the, 17, 123, 130, 131, 143. 147 ; popularity in A.D. $794, \times 73$

Pai Kuong-fa, Abbot, vii.

Palestine, superstition in, 40, 41

Pao Ch'eng, stories by, 104

Parsee rites, the dog in, 12, 49

Parti-colours, points of appreciation, $161-164$

Partridges, netting of, 68

Pearls, Chinese custom of wearing, 162

Pease, Sir A., "The Book of the Lion," 95,122

Pechili, cats of, $x_{4}$ I

"Peiching Kou," term, I42

"Pei Wai Chai Shu Hua P'u," I34 note

Pei Wen Yun Fu, 17

Peking, sale of dog-flesh in, 27 ; the Hatamen, 32 ; the temple of Erh Lang, 35-37; national museum, 58; Lama temple, roo; the Kung Fu, 106; cats of, I4I ; capture by the Manchus, 147,148 ; siege of, 170; visits of the Dalai Lama, I81, 182

Peking Chien Men, the, 106

Pekingese dog, the, breeding, 52; leg fringes, 122 ; historical references, 123 ; evolution of the type, 142, 143, 146; the black and white, 147; introduction into England, $152, \times 53$; points of the, $155^{-1} 5^{8}$; body development, 158, I59; shedding of the coat, 160 ; colours, I60-164; " spectacled," I62, I63

"Pen Tsao Kang No," I 47 note

"Pen-Lo" dogs, I 49 note

Pepys on bull-baiting 46

Perry, "Megalithic Culture of Indonesia," 24, 25

Perry, Capt. J. C., "United States Japan Expedition," I 78

Persia, demand for British dogs, 82 ; lion worship in, 94,95 ; dogs of, 126 ; cats of, 141

Peter the Great, embassy to China, 140,141

204
Pheasants, taking of, with the hawk, 66,68 ; Mongolian, 69

Phcenix, 47

Pi Hsiao Li, eunuch, 153

P'i ngan, the, 7

Pigeon breeding, 47, 52, $x 94$

Pinkerton, "Voyages," $7 \mathrm{I}$ note, I4I note

Ping Yang, 126, 127

Pobrang, 83

Pointer, the British, 5 I

Polo, Marco, cited, $4 \mathrm{I}$ note, 50, 5I, 59, $60,63,79,80,92,134$; description of an Imperial hunt, 93

Polygamy, 192

Pomeranian type, 144

Pope, Alexander, "The Indian and his Dog," 38

Porcelain, Tao Kung period, I 59 ; paintings on, 188 , I9I

Portugal, trade with China, r39; pugs from, 166,167 ; trade with Japan, 173,174

Portuguese, lions possessed by the, 92

Poutiatini, C., 3,4

Poutiatini, Prince, 3

Pratt on the Tibetan mastiff, cited, 8I

"Prince" mark, 170

Pug, the Chinese, 147 ; early introduction into Europe, 166, 167; possible origin in Szechuan, 170

Pug, the English, Chinese origin, 133 ; or probable Dutch origin, 166, 169

Pug type, the, 52 ; colouring, 164,170

Pug-nosed spaniel, the, 54

Pugs, black, 170

"Purchas his Pilgrimes," quoted, 20

Pyn Cushos, the, 83

Pythagoras, teachings, 12

QualL, netting of, 66,68

Quangsi, dogs of, 26

Quangtung, dogs of, 26; eating of dog-flesh in, 27,28

Ramsay, "Western Tibet," 8r, 182

Rameses II., 94

Rees, "Cyclopredia," 24

Ren Tsung, Emperor, 133

Rennie, Dr.,"Peking and the Pekingese," 152,153

Rinjaitzay, 83 


\section{INDEX}

Roch, St., dog of, $3^{8}$

Rockhill, "Life of Buddha," $8 \mathrm{r}$ and note

Roe, Sir John, 82

Rolleston, Prof., "Scientific Papers," I

Romans, the, dog-worship, I I ; dogflesh eaten by, 23, 24; use of the dog in the chase, 5 I

Romero, Julian, 167

Russia, pugs from, 169

SADDAR, cited, 6

Saki, use of, 179,180

Salmon-fishing, use of the dog, 71

Salvatico, Francisco, 73, 74

Samye monastery, Tibet, 40

San Kuo Tien Lueh, 126

Saris, Captain, cited, 46, 47, 64, 74, 175,178

Sash, the, customs regarding, 163

Scent in dogs, development, $5 \mathrm{I}, 58,65$

Schrader, cited, 62

Scott, Sir Walter, 40

Scripture, references to the lion, 11 I

Scythians, I 19

Shadza, dog, 153

Shakespeare, non-mention of tobacco, 16; quoted, 4 I

"Shan hai king," quoted, 8

Shang, Books of, cited, 9

Shansi, province of, 16; dogs of, 123, I 68

Shantung, dogs of, 14 ; dog-flesh from, 27 ; lion figures, 104 ; lion-dog of, 183,184

Shaw, V., "The Book of the Dog," I 69

Shen Chen Lin, paintings of, 189, 190

Shen Heng Chi, dog of, 135

Shensi, greyhound of, 75 ; lion-pillars of, 95

Shi Chi, I 4 note

"Shih King," the, quoted, 7, 63

"Shih," meaning of term, 103

Shih-tsu-Pa-Erh dogs, 52, 149 note

Shinra, king of, 118

Shintoism, I17; the lion in, II8; sun-worship, 120 note

Shock dogs, I 45, I 50, I81, I82

"Short" dogs, 143

"Short-mouthed" dogs, 168

Shot-gun, use, 58,59

"Shuah Shih-tzu," I 6
Shuowen, dogs of, 8

"Shuo wen," the, quoted, 7

Sieber, Max, 10 note

Silk pictures, 188

Silk trade, Chinese 124,128

Sinkiang trade route, 9 I

"Siring," 85

Sirius, I1 , 12

Sledge dogs, Chinese, 70, 7 I

"Sleeve-dogs," I 49 and note-1 52, 165

Sluys, 73

Smith, Vincent A.9 " Asoka," 95, 96

Snuff-bottle, vogue of the, 151, 191-193, I95

Soopoon Choomboo, 99

Sorreze, J., "Roman de Leonardo da Vinci," I 37

Southwark beer garden, 46

Sowerby, " Journal," 6

Spain, dogs from, 65; trade with China, 139

Spaniel, development of the, 65 ; the modern Japanese, 147. See also King Charles Spaniel

Sparrowhawks, 66, 67

"Spectacles," breeding of, 162,163

Speke, "Travels to the Sources of the Nile," 103

Spirit-lion, the, 97, 98; monuments, I 49

Spiti, wolves of, 7

Sporting dogs, ancient Chinese, 56-58

"Square" dogs, 9, I 43

Srong-tsan-gampo of Tibet, I 81

Ssuchuan, dogs of, 130, 131, 133, 1 34, 170

"Ssu-ma-Ch'ien," 8, 10

Stambul, I 28

Stirling, Admiral, 178

"Stop," the, first European reference to, 146

Strabo, cited, 87 note

Street-dogs of Japan, 25, 26, 30, 31

Strutt, Joseph, "Sports and Pastimes of the People of England," 64

Stunting of dogs, discouraged, 152

Suinin, Emperor, 79

Sunbeam, the, 170

Sun-dog, the term, I20 note

Sun-myths, I 16, 117, 120

Sun-worship, the lion associated with, I19-121 


\section{INDEX}

Sung dynasty, dogs of the, 49,132

Sung Yun, pilgrim, 92

Sweden, heraldic lions of, I 6

Sybarites, 144

TABles, Chinese, height of, 130

T'ai Tsung, Emperor, dog of, 128 , $132,133,153$

Takatoki, Emperor, 17

Tang dynasty, imperial dogs, 49 ; toy dogs, 125, 129-131; historical references to pet dogs, 127,128

T'ang, Emperor, decrees of, 8,9

Tao Kuang, Emperor, pigeons of, 194

Tao Kuang period, dogs of the, vii., 52, I 49 ; porcelains, 159 ; docking of tails, 165

Tartar dogs, 70,71

Tartar invasion of China, 124, 125

Tatsienlu, mastiffs of, $8 \mathrm{I}$

Tengeranus, C., 3

Teshu Lama, the, 83, 99 note

Thomas, St., Story of, 102

Thunberg, "Japon," 3 I note

Ti barbarians, dogs of the, 6,8

Tibet, wolves of, 7 ; founding of, ro ; lama beliefs concerning dogs, 39 , 40,53 ; sledge dogs, 71 ; lore of, 98,99 ; lion masques, 115,116 ; conquest in 1645,148 ; early history, $18 \mathrm{r}$; the lion-dog presented to the Manchu Emperors, 182 ; the modern lion-dog, 185

Tibetan lion, the, monuments, 112,113 Tibetan mastiff, the, $60,61,76,77$, $79-83$

Tien-Kow, the heavenly dog, 33, 34

Tientsin, hawking in, 66

Tientsin Treaty, 30

Tiger, kingship of the, 90

Tiglath-Pileser, $94 ;$ menageries of, 9

"Ting-Tzu," I62

Ti-Yang, 28

Tokugawa Iyesasu, tomb of, I 18

Tomb-dogs, 76-79

Tongue of the "Pekingese," I 57

Tower of London, seraglio in, 46

Toy dogs in Chinese art, 188-195

" Toys," Eastern trade in, 178

Trees, symbolism in, 195

Tremayne, "Ban of the Bori," 78

Tribute, dogs as, 8,9

206
Tsai-kou, the, 5

"Tso Chuan," the, quoted, 6

T'u Shu Chi Ch'eng, I 4 note

"Tung K'ao," quoted, I8

T'ung T'ien Bai, 162

Tungus, the, use of dogs' flesh, 22

Turfan, 63

Turkestan, falconry in, 62 ,

Turks, dogs of the, 7,8 ; presents of dogs accepted by the, 125, 126

Turner, Capt. Sam, on Tibetan lore, 98,99

Tzu Hsi, See Empress Dowager

UCHENG, lion-worship at, ro6

Unicorn, the, III

Urbino, Duke of, 44

Ussuri, 70

VAMBÉRY, quoted, 7

Venice, presents of dogs from, 125

Victoria, Bishop of, "Ten Weeks in Japan," I78, 179

Victoria, Queen, "Pekingese" presented to, 152

Vinci, Leonardo da, the Monna Lisa, 137

WADDELl, L. A., " Lamaism," 97

Wan Li, Emperor, 49 , 138

Wang Houchun, vii.

Wang To, dog of, I 3 I

Water-dogs, penalties for killing, 13,14

Watson, James, "The Dog Book," I 50 , 169

Watts, Isaac, 45 note

Wegener, Frau Olga, collection, 189

Wellington, Duke of, 170

Wen Shu, the Chinese, 148

White, on the Chow, cited, 69, 70, 77 note

Wieger, Dr. L., " Buddhism," 39, 106

William of Orange, the pug popular with, 166,167

Williams, Dr. Wells, cited, 27, 71

Williams, Sir Roger, 167

Willoughby pug, the, 169

Wilson, "Antiquities of Afghanistan," 88

"Wo," dog, I30

Wo Tzu breed, 173 


\section{INDEX}

Wolf, the, the domestic dog evolved from, 2,5 ; the Chinese grey, 6 ; origin of certain Chinese dogs, 6,7

Wolf-hound, the Chinese, 75,76

Woo King, 9

Wu Ch'i-ts'un, Mr., vii.

Wu Liang, bas reliefs, 72,73

Wu Yeh, Prince, vii.

Wynne, M. B., "History of the Mastiff," 9 note, 6I

Xavier, St. Francis, 73

YAK, 80

Yang, 28

Yang Ti, Emperor, 125, 127

Yi Chou Shu, II

Yin Liu, eunuch, 194,195

Youatt, on noses, quoted, 168

Ysbrants, Ides, "Three Years' Travel," 21,22

Yü lin dogs, 79
Yu Pi T'ung Ch'ien, cited, 19,127

"Yuan Chuan Lei Han," quoted, 8, 9, I $3 \mathrm{I}$ note, $\mathrm{r} 32, \mathrm{I} 33$ note

Yuan dynasty, menageries of the, 134 ; dogs, 147

Yuan Shih k'ai, President, vii.

Yuan Wei Ch'ih, $x_{30}$

Yuen Ming Yuan palace, 152

Yuen-chuang, 136

Yule, "Cathay and the Way Thither," $50,92,93,128,134,140$

Yung Ho Kung-Temple, 94

Yung Kwei Fei, beauty of, 129, 130

Yunnan Province, dogs of, $6,77,80$, 84

ZAPUNTELLO, I29, 144 and note

Zend Avesta, reference to the, $6,12-14$, 3 I $, 32,36,49,86$

Zoological Society, hairless dogs 7 I

Zosoastrians, punishments for dogkilling, $\mathrm{I} 3, \mathrm{r} 4$ 






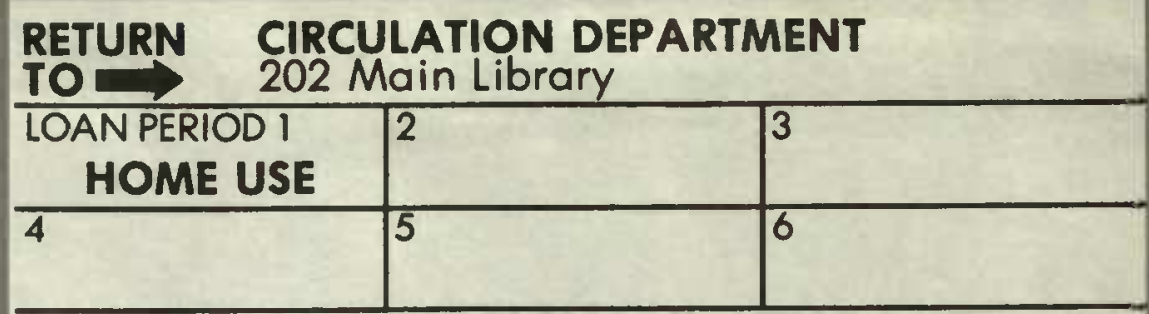

ALL BOOKS MAY BE RECALLED AFTER 7 DAYS

1-manth loons may be renewed by calling $642-3405$

6-month loans may be recharged by bringing books to Circulation Desk

Renewals and recharges may be made 4 days prior to due date

\section{DUE AS STAMPED BELOW}

\begin{tabular}{|c|c|c|}
\hline $\begin{array}{l}\text { HAY } 151978 \\
\text { HUG }\end{array}$ & SEP ₹ 4 19685TO DI & CCIRC NOV 18 '92 \\
\hline JUL 11981 & JUN 151989 & \\
\hline REG CIL JUN 1 T981 & APRI 7190 & \\
\hline DEC 101981 & GUTO DISG DEC $08^{\prime} 90$ & \\
\hline $\operatorname{anc} 101982$ & BUES DFC 191990 & \\
\hline 2,982 & (1) कीजिए & \\
\hline RTID JAN 28 & क82 & \\
\hline METD JAN 28 19\% & & \\
\hline SEP $=-2305$ & & \\
\hline $\begin{array}{l}\text { SEP \& } 1986=-1 \\
\text { FORM NO. DD } 6,40 \mathrm{~m}\end{array}$ & $\frac{-}{10} 77$ UNIVERSITY & $\begin{array}{l}\text { CALIFORNIA, BERKELEY } \\
\text { LEY, CA } 94720\end{array}$ \\
\hline
\end{tabular}




\section{GENERAL LIBRARY - U.C. BERKELEY}

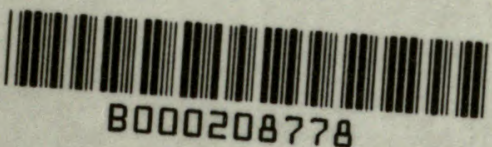

YE 02096́

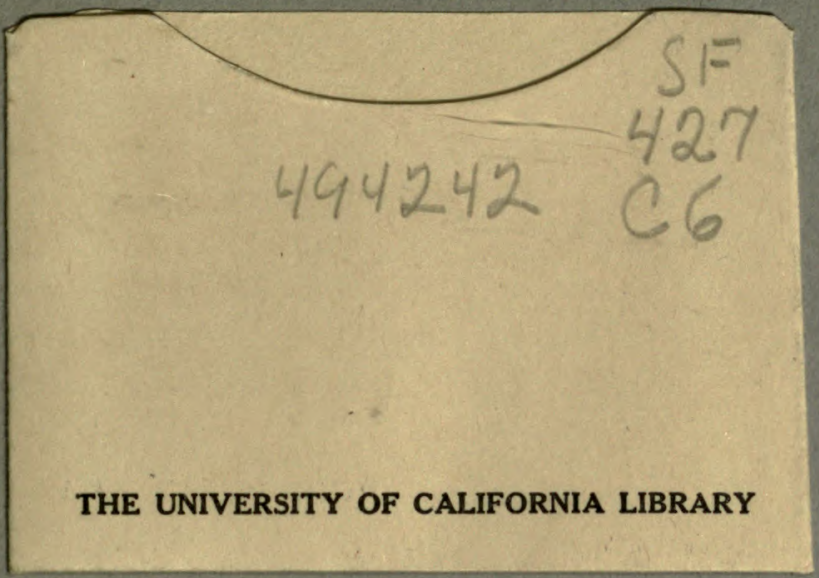




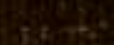

195:

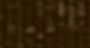

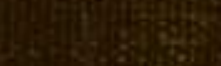

